\title{
Evaluating mantle and crustal processes using isotope geochemistry \\ By
}

\author{
Alberto Edgardo Saal
}

B.S. Geology, Universidad Nacional de Córdoba, Argentina, 1985

Ph.D. Geology, Universidad Nacional de Córdoba, Argentina, 1993

M.S. Geochemistry, Massachusetts Institute of Technology, 1994

Submitted in partial fulfillment of the requirements for the degree of

Doctor of Philosophy

at the

\section{MASSACHUSETTS INSTITUTE OF TECHNOLOGY \\ and the \\ WOODS HOLE OCEANOGRAPHIC INSTITUTION}

September 1999

(C) 1999 Alberto E. Saal

All rights reserved.

The author hereby grants to MIT and WHOI permission to reproduce paper and electronic copies of this thesis in whole or in part and to distribute them publicly.

Signature of Author

Joint Program in Oceanography, Massachusetts Institute of Technology and Woods Hole Oceanographic Institution September 1998

Certified by

Stanley R. Hart, Thesis Supervisor

Accepted by

Timothy L. Grove Chair, Joint Committee for Marine Geology and Geophysics Massachusetts Institute of Technology/

Woods Hole Oceanographic Institution 


\section{Acknowledgment}

There are no right words to thank my friend and mentor Stan Hart. Stan provided the freedom, the equilibrium, the will, the confidence, the brightness and the friendship necessary to make my dream possible, a dream long overdue: to work in science at the best level and to have fun doing my work. Life is so short and so important! that 1 feel fortunate to have shared the same space and time with Stan Hart.

I would like to thank Fred Frey and Nobu Shimizu; both have been fundamental in my education as a Geochemist. Fred teaching me the secrets of trace element geochemistry and Nobu opening the doors to the new world of micro-analysis. I surely will miss their friendship and our frequent and enjoyable scientific discussions.

I owe a large part of my education to Mark Kurz, Greg Ravizza and Bernhard Peucker-Ehrenbrink. They introduced me to the importance of studying rare gases and low temperature geochemistry in magmatic processes. They have been excellent teachers and friends.

All my work would have not been possible without the teaching, the help and the patience of Jurek Blusztajn, Graham Layne, Ken Sims, Greg Ravizza, Bernhard PeuckerEhrenbrink and Larry Ball.

I thank all my friends that in one way or another have contributed with their help and friendship to my development as a scientist. Eiichi Takazawa, Ken Koga, Huai-Jen Yang, Jurek Blusztajn, Debbie Hassler, Glenn Gaetani, Erik Hauri, Tom Wagner, Jim Van Orman, Steve Parman, Kirsten Nicolaysen, Mark Martin and Rhea Workman.

I benefited tremendously from the fruitfull discussion and work with Roberta Rudnick, Erik Hauri, Peter Kelemen, Tim Grove, Greg Hirth and Sam Bowring. I specially thank Peter Kelemen, who was fundamental in my decission to get in the MIT/WHOI joint program.

I am thankful for Geochemistry Seminar at WHOI and the Reading Seminar with Fred Frey at MIT. These two seminars have been the best learning experience during my $\mathrm{Ph} . \mathrm{D}$. 
Thanks to the administrative, security and maintenance people at WHOI and MIT who help me during all this years.

\author{
Alberto E. Saal \\ September, 1999
}




\section{Table of Contents}

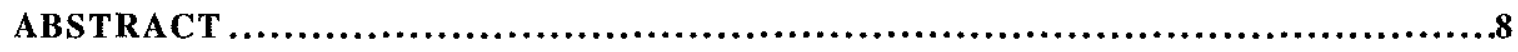

INTRODUCTION................................................................. 1

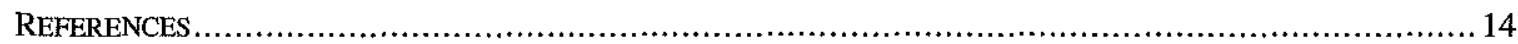

CHAPTER 1: RE-OS ISOTOPE EVIDENCE FOR THE COMPOSITION, FORMATION AND AGE OF THE LOWER CONTINENTAL CRUST................16

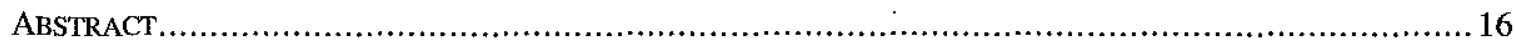

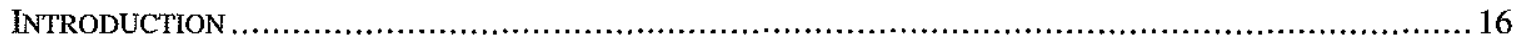

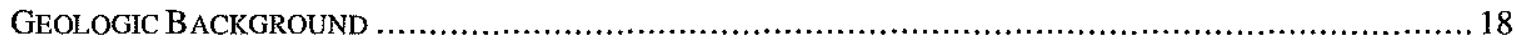

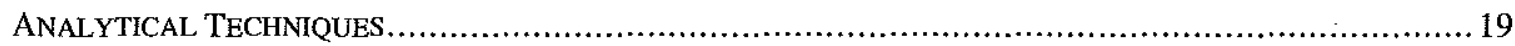

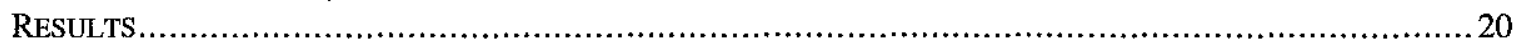

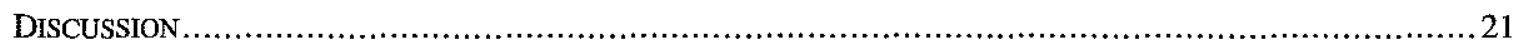

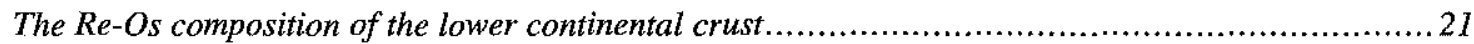

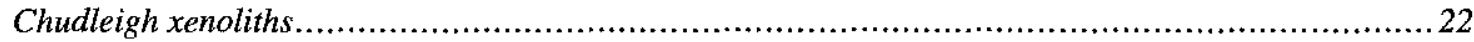

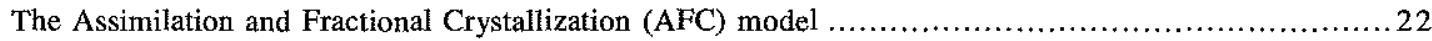

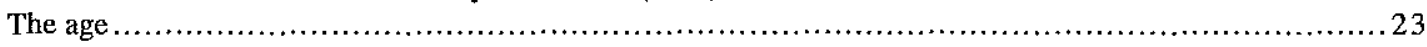

Continental basalts, mantle heterogeneity or lower crustal contamination? ...............................25

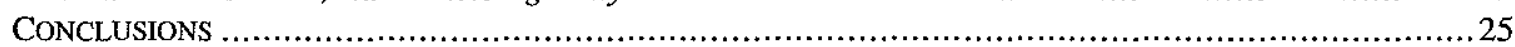

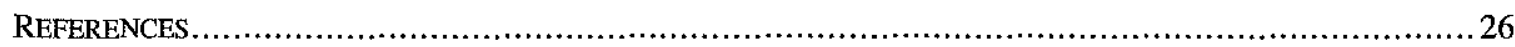

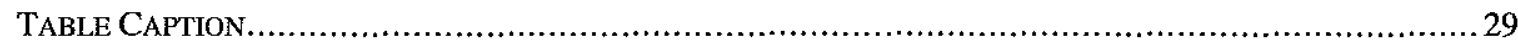

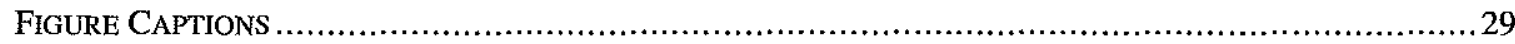

CHAPTER 2: RE-OS ISOTOPIC COMPOSITION OF THE HOROMAN PERIDOTITE: IMPLICATIONS FOR THE GENESIS OF THE PLAGIOCLASE LHERZOLITE AND THE LAYERED STRUCTURE.................41

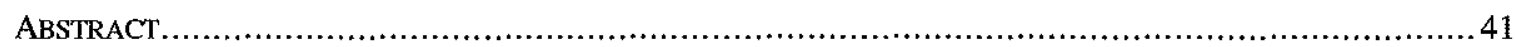

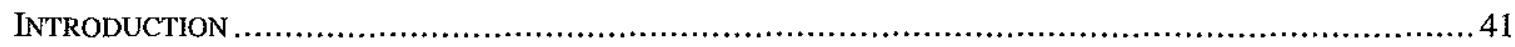

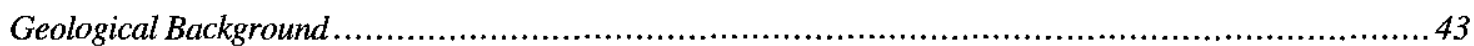

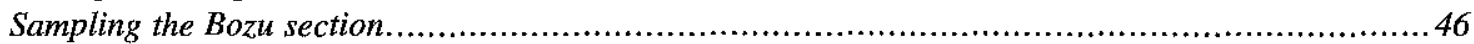

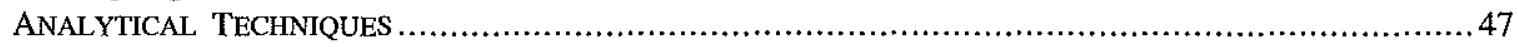

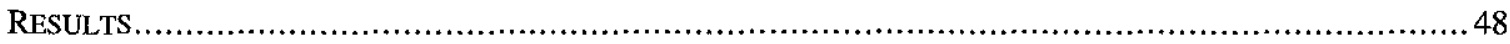

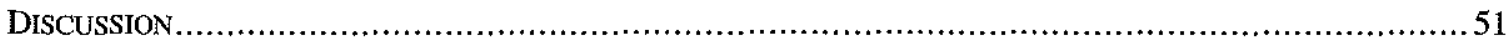

What controls the Re/Os systematics of the Horoman peridotite? .............................................51

What is the process (or processes) responsible for the variation in the basaltic component in the

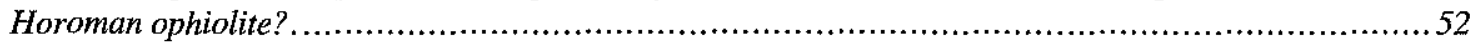

Can the mixing hypothesis explain the major and trace element contents of the fertile plagioclase

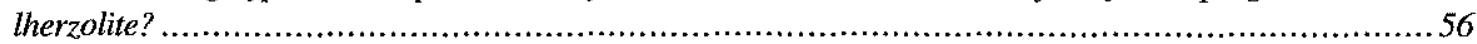

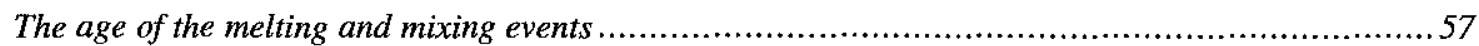

Is Horoman an unusual place or does the refertilization process play a role in other ophiolitic massifs? 58

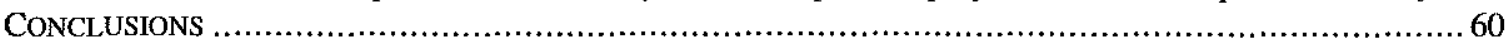

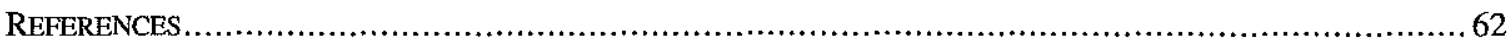

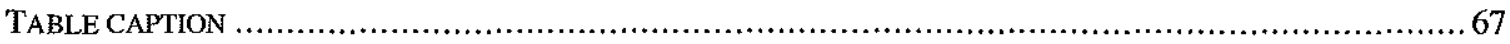

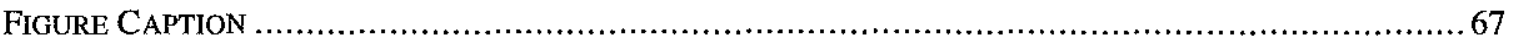

CHAPTER 3: PB ISOTOPIC VARIABILITY IN MELT INCLUSIONS FROM

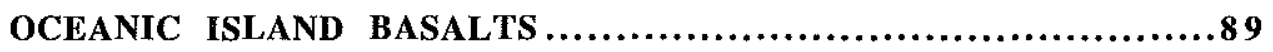




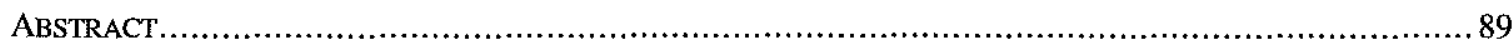

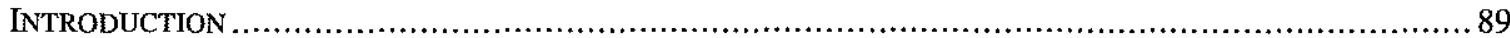

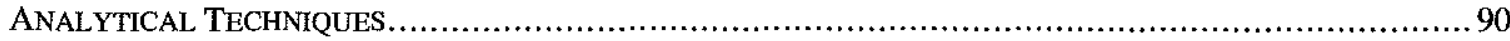

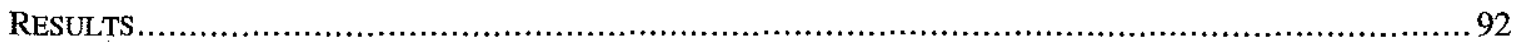

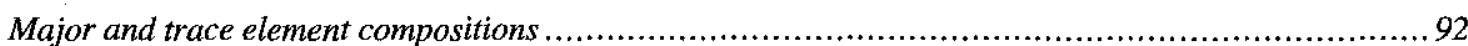

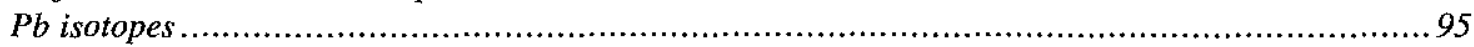

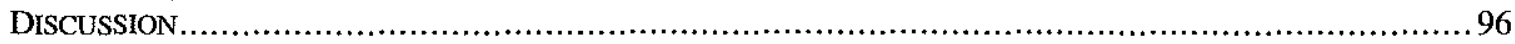

Petrography, major and trace element composition of the melt inclusions ............................... 96

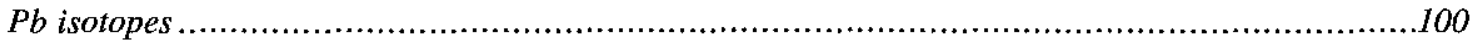

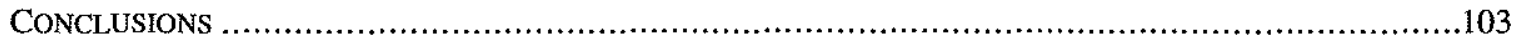

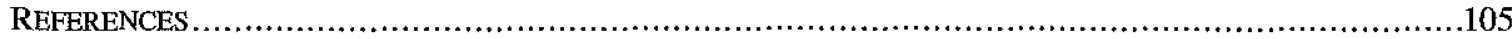

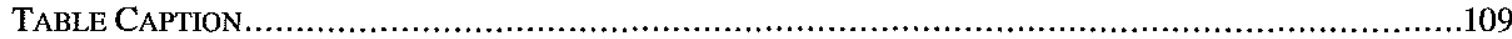

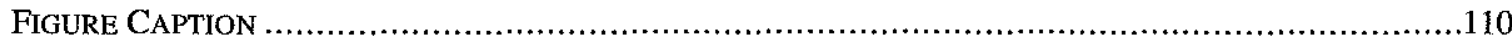

CHAPTER 4: U SERIES ISOTOPIC VARIABILITY IN GALAPAGOS LAVAS, EVIDENCE OF A WARM-SPOT ............................................... 55

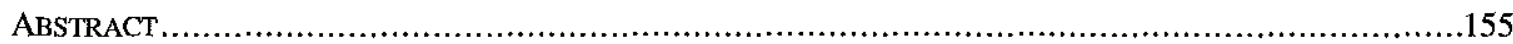

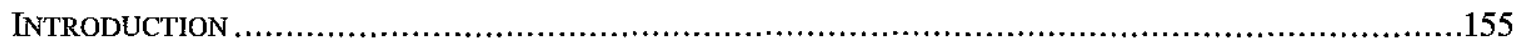

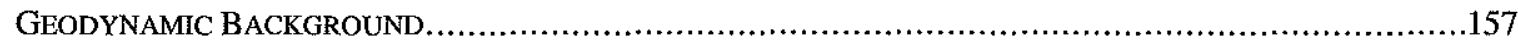

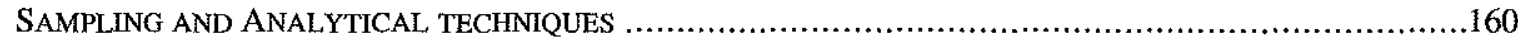

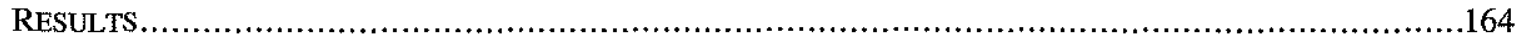

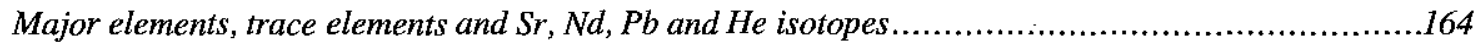

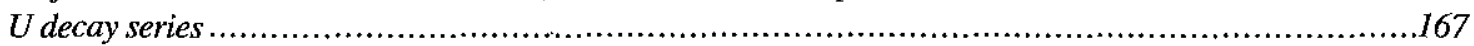

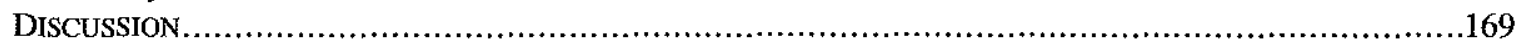

Extent of melting and pressure of melt segregation. ...............................................................169

Seeing through melting and the mixing, to source characteristics....................................172

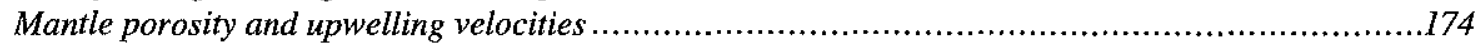

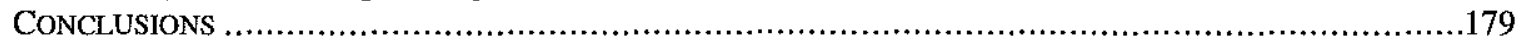

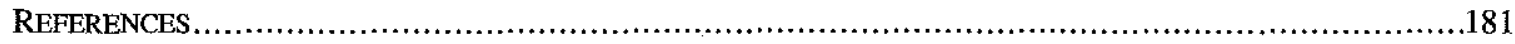

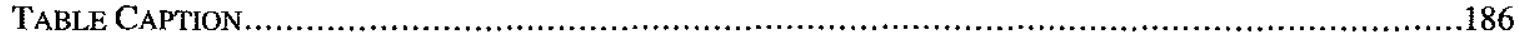

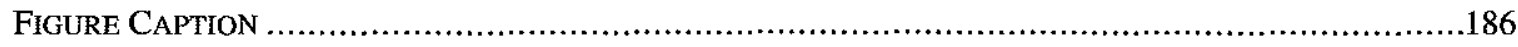

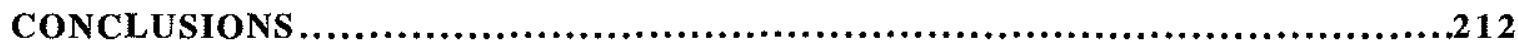




\title{
Evaluating mantle and crustal processes using isotope geochemistry
}

\author{
by \\ Alberto E. Saal \\ Submitted to the Department of Earth, Atmospheric, and Planetary Sciences \\ Massachusetts Institute of Technology \\ and \\ Department of Geology and Geophysics \\ Woods Hole Oceanographic Institution \\ in partial fulfillment of the requirements for the degree of Doctor of \\ Phylosophy
}

\section{Abstract}

Geochemical studies are fundamental for understanding how the dynamic Earth works and evolves. These studies place constraints on the composition, formation, age, distribution, evolution and scales of geochemically distinct reservoirs such as the Earth's crust, mantle and core. In this dissertation the strategy has been to work on a broad range of topics to evaluate crustal and mantle processes. This study presents Re-Os systematics to constrain the composition, formation and age of the lower continental crust and the mantle lithosphere, examines melt inclusion from oceanic island basalts to evaluate the scale of the mantle heterogeneities, and uses $U$-series isotope to constrain geodynamic parameters, such as the upwelling velocities and porosities of mantle plumes.

The lower continental crust plays a pivotal role in understanding the composition and evolution of the continental crust and the petrogenesis of continental basalts. This chapter presents $\mathrm{Re} / \mathrm{Os}$ isotope measurements which allow us to further our understanding of these problems. Two well-characterized suites of lower crustal xenoliths from Northern Queensland, Australia, which have average major and trace element compositions similar to bulk lower crust, were analyzed for Re/Os isotope systematics. From this data, we infer that the lower crust has 1 to 2 times as much Os, about half of the Re and is less radiogenic in ${ }^{187} \mathrm{Os} /{ }^{188} \mathrm{Os}$ than the upper continental crust. Our data show that assimilation and fractional crystallization (AFC) are important processes in the formation of the lower crust and lead to dramatic changes in the Os isotopic composition of basalts that pond and 
fractionate there. Because of this, the Re-Os system cannot be relied upon to yield accurate mantle extraction ages for continental rocks.

Chapter 2 examines the Re-Os isotopic composition of the Horoman massif, Japan. These data indicate that the Os isotope composition is controlled by the Re content, through radiogenic ingrowth, while the $\mathrm{Re}$ content is governed by the extent of depletion in "basaltic component" of the ultramafic rocks. Re-Os systematics suggest that depletion model ages of $\approx 1.8 \mathrm{Ga}$ represent the age of the melting event. The colinearity between mafic and ultramafic rocks in the Re-Os isochron diagram defines an apparent age of $\approx$ $1 \mathrm{Ga}$.. The similar "ages" determined by Re-Os and Sm-Nd isotopes and the high Re/Os ratios in the most fertile peridotites plotting to the right of the geochron, indicate that the mafic layers and the ultramafic rocks are genetically related by a refertilization process which took place $\approx 1 \mathrm{Ga}$ ago. The Re-Os systematics for' other ophiolitic massifs indicate that refertilization of the lithospheric mantle seems to be a more widespread process than previously thought.

Previous studies have suggested that melting processes are responsible for the trace element variability observed in olivine-hosted basaltic melt inclusions. Melt inclusions from four individual lava samples representing three mantle end-members HIMU, EMI and EMII (two from Mangaia, Cook Islands, one from Pitcairn, Gambier chain, and one from Tahaa, Society chain), have heterogeneous $\mathrm{Pb}$ isotopic compositions, even though the erupted lavas are isotopically homogeneous. The range of $\mathrm{Pb}$ isotopic compositions from individual melt inclusions in a single lava flow spans $50 \%$ of the world-wide range observed for ocean island basalts (OIB). The melt inclusion data can be explained by two-component mixing for each island. Our data imply that magmas with different isotopic compositions existed in the volcanic plumbing system prior to or during melt aggregation.

Evaluation of $\mathrm{U}$-series disequilibrium, trace element composition and $\mathrm{He}, \mathrm{Sr}, \mathrm{Nd}$ and $\mathrm{Pb}$ isotopes of Galapagos lavas indicates that magma mixing between plume and asthenospheric melts has been the main process responsible for the geochemical variation observed in the archipelago. Correlations between $\mathrm{He}$ isotopes and $\mathrm{Ti} / \mathrm{Ti}$ *, $\mathrm{K} / \mathrm{Rb}$ and $\mathrm{Nb} / \mathrm{La}$ ratios suggest that the mantle plume has positive anomalies of $\mathrm{Nb}$ and $\mathrm{Ti}$ and negative anomalies of $\mathrm{K} .{ }^{230} \mathrm{Th}$ excesses measured in the lavas indicate that the basalts from Galapagos originated completely or partially in the garnet stability field. Mantle upwelling velocity for the Galapagos plume (Fernandina) ranges from $\approx 1$ to $3 \mathrm{~cm} / \mathrm{y}$ with a maximum 
porosity of $0.3 \%$, indicating that Galapagos is a mildly buoyant plume. Very slow mantle upwelling rates and very low porosity for Pinta $(0.5$ to $1 \mathrm{~cm} / \mathrm{y}$ and $0.1 \%)$ and Floreana $(0.1 \mathrm{~cm} /$ year and $<0.1 \%)$ islands, support the hypothesis that the movement of the plume across the $91^{\circ} 50^{\prime}$ transform fault into a younger and thinner lithosphere produced slow upwelling and small extents of melting.

Thesis Supervisor: Stanley R. Hart

Senior Scientist

Woods Hole Oceanographic Institution 


\section{Introduction}

The long term goal of studying basalts, crustal rocks and mantle peridotites is to date and deconvolve the superimposed effects of processes responsible for the geochemical variations found in the Earth's crust and mantle. This dissertation attempts to use geochemical tracers such as major elements, trace elements and radiogenic isotopes to add constraints to the geologic processes responsible for the composition, formation and age of various geochemical reservoirs, such as the lower continental crust and the continental mantle lithosphere. Moreover, this study makes use of geochemical tracers in oceanic island basalts to assess the scale of mantle heterogeneities and to define geodynamic parameters during upwelling and melting of mantle plumes.

Chapter 1 applies Re-Os systematics to determine the composition, formation and age of the lower continental crust. The study of the lower continental crust is a key component in estimating the composition and age of the continental crust as a whole (Rudnick and Fountain, 1995). Whereas the upper continental crust is accessible to sampling, the deeper portions of the crust are relatively inaccessible. Lower crustal xenoliths are intact samples from the present-day lower continental crust (Taylor and McLennan, 1995, Rudnick, 1992). Therefore, the study of such xenoliths is very important for determining the bulk composition and origin of the lower continental crust. This study reports Re-Os isotopic data for two geochemically well-characterized suites of lower crustal xenoliths from Northern Queensland, Australia (Rudnick and Goldstein, 1990 and references therein). These data show that assimilation and fractional crystallization processes (AFC) are responsible for the formation and composition of the lower continental crust, and that whole rock Re-Os isochrons for magmas processed in the lower crust may not give reliable age or source composition information.

Chapter 2 examines the Re-Os systematics of a geochemically well-characterized $140 \mathrm{~m}$ section across the layered Horoman peridotite, Japan. The Horoman massif has been the subject of numerous structural, petrologic and geochemical studies (Takazawa et al., 1999a, 1999b and references therein). However, the process (or processes) responsible for the formation of the layering, as well as the origin of the fertile plagioclase lherzolite, still remains controversial. The origin of the layered structure has been explained either by melting processes (Takazawa et al., 1999b; Yoshikawa and Nakamura, 1999; Takahashi, 1992) or by a combination of melting and melt accumulation (Obata and 
Nagahara, 1987). The Re-Os systematics seem to support the second hypothesis, where the layered structure in the Horoman massif is produced by a combination of melting and melt accumulation, with the plagioclase lherzolite representing the region of melt accumulation.

Chapter 3 applies an old geochemical tool, $\mathrm{Pb}$ isotopes, to a new dimension in isotope geochemistry by analyzing $\mathrm{Pb}$ isotopes in single melt inclusions from oceanic island basalts. Studies of oceanic basalts have shown that the mantle is isotopically heterogeneous (Zindler and Hart, 1986; Hart et al, 1992 and references therein). However, the nature, distribution, and scale of these heterogeneities remain uncertain. The aggregation of melts on their way to the surface, and mixing in magma chambers prior to eruption, can obscure the chemical and isotopic signatures of pre-aggregated melts. Studies of olivine-hosted melt inclusions have been successful in defining the chemical composition of pre-aggregated melts (Sobolev and Shimizu, 1993). However, the lack of isotopic information on melt inclusions has made it difficult to distinguish whether these melt compositions represent different extents of melting from a single source or whether they originate from different source compositions. The range in $\mathrm{Pb}$ isotopic composition observed in melt inclusions from single lava flows suggests that the geochemical variation in melt inclusions has a large component of source control, and is mainly produced either by some mixing of melts or assimilation and fractional crystallization processes deep in the magma chambers.

Chapter 4 presents the first $U$ decay series isotopes study of lavas from the Galapagos archipelago. ${ }^{238} \mathrm{U}-{ }^{230} \mathrm{Th}-{ }^{232} \mathrm{Th}$ isotopes place unique constraints on magmatic processes and mantle source compositions. ${ }^{238} \mathrm{U}^{230} \mathrm{Th}$ disequilibrium provides quantitative evaluation of the present-day depletion of the mantle source, the extent of melting represented by erupted lavas, and helps to constrain estimates of the mantle porosity and upwelling velocities during melting (Elliot, 1997 and references therein). Although the Galapagos islands have been interpreted as the surface manifestation of mantle plumes, geological, geophysical and geochemical studies have found it challenging to fit Galapagos magmatism to a "standard" hotspot model (Kurz and Geist, 1999). The diffuse nature of the Galapagos plume, and the dynamic melting and equilibrium porous flow models using $\mathrm{U}$ decay series isotopes constrain mantle upwelling velocities for the Galapagos plume (Fernandina) to $\leq 3 \mathrm{~cm} / \mathrm{y}$ and maximum porosities of $0.3 \%$. These results indicate that 
Galapagos is a mildly buoyant plume, significantly less intense thermally than the Hawaiian hotspot. 


\section{References}

Elliot T., Fractionation of $U$ and Th during mantle melting: a reprise. Chem. Geol. 139: 165-183, 1997.

Hart S. R., Hauri E. H., Oschmann L. A. and Whitehead J. A. , Mantle plumes and entrainment: isotopic evidence. Science 256, 517-520, 1992.

Kurz M. D. and Geist D. J., Dynamics and evolution of the Galapagos hotspot from helium isotope geochemistry. Geochim Cosmochim Acta (in press), 1999.

Obata M. and Nagahara N., Layering of apline-type peridotite and the segregation of partial melt in the upper mantle. J. Geophys. Res 92: 3467-3474, 1987.

Rudnick, R. L., Xenoliths - Samples of the lower continental crust. In: The Continental Lower Crust (eds. Fountain, D. M., Arculus, R. and Kay, R.) 269-316 (Elsevier, Amsterdam, 1992).

Rudnick, R. L. and Fountain, D. M., Nature and composition of the continental crust: a lower crustal perspective. Rev. Geophys. 33, 267-309 (1995).

Rudnick, R. L. and Goldstein, S.L., The $\mathrm{Pb}$ isotopic compositions of lower crustal xenoliths and the evolution of the lower crustal Pb. Earth Planet. Sci. Lett. 98, 192-207 (1990).

Sobolev A. V. and Shimizu N., Ultra-depleted primary melt included in an olivine from the mid-Atlantic ridge. Nature , 363, 151-154, 1993.

Takahashi N. Evidence for melt segregation towards fractures in the Horoman mantle peridotite complex. Nature, 359: 52-55, 1992.

Takazawa E., Frey F. A., Shimizu N., Saal A. E. and Obata M., Polybaric petrogenesis of mafic layers in the Horoman peridotite complex, Japan. J Petrology (accepted for publication) 1999a.

Takazawa E., Frey F. A., Shimizu N. and Obata M. Whole-rock compositional variations in an upper mantle peridotite (Horoman, Hokkaido, Japan): Implications for melt segregation, migration and reaction. Geochim Cosmochim. Acta (accepted with revisions) $1999 \mathrm{~b}$.

Taylor S. R. and McLennan, S. M., The geochemical evolution of the continental crust. Rev. Geophys. 33, 241-265 (1995).

Yoshikawa M. and Nakamura E., Geochemical evolution of the Horoman peridotite complex: Implications for melt extraction, metasomatism and compositional layering in the mantle. J. Geophys. Res (under review) 1999. 
Zindler A. and Hart S. R., Chemical geodynamics.. Ann. Rev. Earth Planet. Sci. 14, 493571,1986 


\section{Chapter One}

\section{Re-Os isotope evidence for the composition, formation and age of the lower continental crust}

\subsection{Abstract}

The lower continental crust plays a pivotal role in understanding the composition and evolution of the continental crust and the petrogenesis of continental basalts. We present $\mathrm{Re} / \mathrm{Os}$ isotope measurements which allow us to further our understanding of these problems. Two well characterized suites of lower crustal xenoliths from Northern Queensland, Australia, which have average major and tracè element compositions similar to bulk lower crust, were analyzed for Re/Os isotope systematics. From this data, we infer that the lower crust has 1 to 2 times as much Os, about half of the Re and is less radiogenic in ${ }^{187} \mathrm{Os} /{ }^{188} \mathrm{Os}$ than the upper continental crust. Our data show that assimilation and fractional crystallization (AFC) are important processes in the formation of the lower crust and lead to dramatic changes in the Os isotopic composition of basalts that pond and fractionate there. Because of this, the Re-Os system cannot be relied upon to yield accurate mantle extraction ages for continental rocks.

\subsection{Introduction}

Determining the composition and age of the continental crust is fundamental to an understanding of the evolution of the Earth (Taylor and McLennan, 1995, Rudnick, 1995). The study of the lower continental crust is a key component in estimating the composition and age of the continental crust as a whole (Rudnick and Fountain, 1995). Whereas the upper continental crust is accessible to sampling, and sediments provide a good means to obtain its average composition, the deeper portions of the crust are relatively inaccessible. The sampling of lower crust is limited to granulite facies terrains exposed during major tectonic events, and xenoliths carried from lower crustal depths deep to the surface by alkali basalts. Not all granulitic terraines represent the deep crust, and only those terrains that have undergone isobaric cooling for long periods of time (>100 Ma.) can be representative of the lower crust (Rudnick and Taylor, 1987). In contrast, lower crustal xenoliths are intact samples from the present-day lower continental crust (Taylor and McLennan, 1995, 
Rudnick, 1992). Therefore, the study of such xenoliths is very important for determining the bulk composition and origin of the lower continental crust.

$\mathrm{Re}$-Os differs from other isotopic systems ( $\mathrm{Pb}, \mathrm{Sr}, \mathrm{Hf}$ and $\mathrm{Nd}$ ) because $\mathrm{Re}$ and $\mathrm{Os}$ are siderophile and chalcophile (rather than lithophile) elements, and because Os is a compatible element (Os is retained in the crystals) during partial melting or fractional crystallization (Hart and Ravizza, 1996). This compatible behaviour leads to high Re/Os ratios and radiogenic Os isotopic compositions in the continental crust (Allègre and Luck, 1980) and makes ${ }^{187} \mathrm{Os} /{ }^{188} \mathrm{Os}$ ratios in fractionating mantle-derived magmas susceptible to change by crustal contamination (Reisberg et al, 1993; Marcantonio et al., 1995; RoyBarman and Allègre, 1995; Widom and Shirey, 1991; Martin et al., 1991; Walker et al., 1997). The slow evolution of ${ }^{187} \mathrm{Os} /{ }^{188} \mathrm{Os}$ in the mantle contrasts with the much more rapid growth of radiogenic Os in most crustal rocks (Allègre and Luck, 1980). Thus, Os isotopes should be a clear discriminator between crustal and mantle material (Walker et al., 1991; Walker et al., 1994; Horan et al., 1995). The Re-Os isotope systematics of the lower continental crust are important for evaluating

1) the processes responsible for the formation, composition, and age of the lower crust (Taylor and McLennan, 1995; Rudnick , 1992; Zandt and Ammon, 1995; Halliday et al., 1993; Rudnick and Fountain, 1995; Rudnick, 1995; Rudnick and Presper, 1990

2) the average Re-Os isotopic composition and concentration of the bulk continental crust (Rudnick , 1992);

3) the sensitivity of Re-Os as an indicator of crustal contamination, and the extent to which basalts erupted through the continental crust have chemically exchanged with the deepest crust (Martin, 1989; Lambert et al., 1989; Walker et al., 1991; Marcantonio et al., 1993; Walker et al., 1994; Horan et al., 1995)

We report Re-Os isotopic data for two geochemically well-characterized suites of lower crustal xenoliths from Northern Queensland, Australia (Rudnick et al., 1986; Rudnick and Taylor, 1987; Rudnick and Williams, 1987; Rudnick and Goldstein, 1990; Rudnick 1990; Rudnick and Taylor, 1991; Kempton and Harmon, 1992). In this paper, we use the Re-Os isotopic systematics of these lower crustal xenoliths to show that assimilation and fractional crystallization processes (AFC) are responsible for the formation 
and composition of the lower continental crust. We assess the sensitivity of the Re-Os isotopic system as an indicator of crustal contamination, and test whether there is decoupling between Os and other isotopic systems during assimilation processes. Finally, we show that whole rock Re-Os isochrons for magmas processed in the lower crust may not give reliable age information.

\subsection{Geologic Background}

Two suites of granulite-facies xenoliths, Chudleigh and McBride, from North Queensland have been the subject of extensive petrological and geochemical studies (Rudnick et al., 1986; Rudnick and Taylor, 1987; Rudnick and Williams, 1987; Rudnick and Goldstein, 1990; Rudnick 1990; Rudnick and Taylor, 1991; Kempton and Harmon, 1992). The Chudleigh xenoliths were carried in <2 Ma basalts erupted through Paleozoic rocks of the Tasman fold belt. Three types of xenoliths are present: plagioclase-rich, pyroxene-rich and transitional between these two groups. Mineralogical studies indicate that the xenoliths underwent isobaric cooling at moderate to high pressure $(\approx 0.7$ to 1.5 $\mathrm{GPa}$.). These xenoliths are mafic in composition $\left(\mathrm{SiO}_{2}<51.2 \mathrm{wt} \%\right)$, and show good correlations between isotopic compositions, trace element contents and $\mathrm{Mg \#} \mathrm{(molar}$ $\mathrm{Mg} /(\mathrm{Mg}+\mathrm{Fe})$ ratios). These correlations were used to argue that the samples are geneticallyrelated cumulates from basaltic liquids, something which is very unusual to find in lower crustal xenolith suites (Rudnick et al., 1986; Rudnick and Goldstein, 1990; Rudnick and Taylor, 1991; Kempton and Harmon, 1992). Rudnick et al. (1986), conclude that the age of the Chudleigh xenoliths is relatively young $(<100 \mathrm{Ma})$, probably related to the Cenozoic igneous activity which occurs throughout eastern Australia (Rudnick et al., 1986).

The McBride xenoliths were carried by $<3 \mathrm{Ma}$ basalts erupted through the Proterozoic Georgetown inlier. These xenoliths range in composition from mafic to felsic, although mafic compositions dominate. Therefore, their chemical compositions reflect equally diverse protoliths, ranging from mafic cumulates, to mafic and felsic melts, and restites of the anatexis of metapelitic sediments (Rudnick and Taylor, 1987; Rudnick and Goldstein, 1990; Rudnick 1990; Rudnick and Taylor, 1991; Kempton and Harmon, 1992). As in Chudleigh, the xenoliths underwent isobaric cooling at moderate to high pressure (> $0.7 \mathrm{GPa}$.). The age of these rocks has been determined by $\mathrm{U}-\mathrm{Pb}$ zircon techniques (Rudnick and Williams, 1987). Most of the ages show xenoliths formation times $\approx 300 \mathrm{Ma}$ ago, during calc-alkaline igneous activity. In contrast, some of the xenoliths apparently 
formed during the Proterozoic $\approx 1570 \mathrm{Ma}$. Therefore the protoliths for the McBride xenoliths formed during large-scale mixing between Proterozoic crust and basalts during late-Paleozoic ( $300 \mathrm{Ma}$ ) convergent margin magmatism (Rudnick and Taylor, 1987; Rudnick and Goldstein, 1990; Rudnick 1990; Rudnick and Taylor, 1991; Kempton and Harmon, 1992).

\subsection{Analytical Techniques}

The samples were washed in ultrasonic bath with Millipore water, and dried on a hotplate at $50^{\circ} \mathrm{C}$. Approximately $50 \mathrm{~g}$ of material was selected from each sample; the samples were wrapped in plastic and hammered to small chips, and the chips were powdered in an agate shatterbox.

The analytical techniques for Re-Os isotopes are described in Ravizza and Turekian (1989), Hauri and Hart (1993) and Peucker-Ehrenbrink et al., (1995). Re and Os were determined on separate powder splits. For the analysis of Os, $15 \mathrm{~g}$ of sample powder was digested by a NiS fire-assay technique. The powder is spiked with a solution of enriched ${ }^{190} \mathrm{Os}$, and mixed with high purity boric acid, Ni and $\mathrm{S}$ powders. The 1.5:1 mixture of flux to sample was melted at 1050 to $1150^{\circ} \mathrm{C}$. This step produced a NiS bead that scavenges Os from the fused rock. The bead is dissolved in $6 \mathrm{~N} \mathrm{HCl}$ and the solution is filtered to recover the PGE particulates. The filter is dissolved in an oxidizing $\mathrm{CrO}_{3}+\mathrm{H}_{2} \mathrm{SO}_{4}$ acid solution, from which the $\mathrm{OsO}_{4}$ is distilled and trapped in $\mathrm{HBr}$ acid. The $\mathrm{HBr}$ solution is dried down to a 1-2 $\mu 1$ drop and diluted in $\mathrm{H}_{2} \mathrm{O}$ until a solution of $1 \mathrm{~N} \mathrm{HBr}$ is obtained. A single bead of Chelex 50 resin is added to the solution, and Os is partitioned into the resin bead at low normality $\mathrm{HBr}$. The bead is deposited in concentrated $\mathrm{HBr}$ to liberate the Os, which is then loaded on a $\mathrm{Pt}$ filament with $\mathrm{BaNO}_{3}$ as an activator. The Os concentrations and isotopic compositions were measured by negative thermal ionization mass spectrometry on NIMA$\mathrm{B}$ (WHOI), with oxygen enhanced emission and analog multiplier detection using a single collector and a dynamic collection routine.

For Re analysis, $0.5 \mathrm{~g}$ of sample powder is spiked with a solution of enriched ${ }^{185} \mathrm{Re}$, and digested in a mixture of $\mathrm{HF}-\mathrm{HNO}_{3}$. Re is extracted by simple ion exchange techniques, using AG1X8 resin. The Re is absorbed into the resin from $0.5 \mathrm{~N} \mathrm{HNO}_{3}$, and then eluted in $4 \mathrm{~N} \mathrm{HNO}_{3}$. An identical second step is used to further purify the Re. The $\mathrm{Re}$ 
measurements were done on a Finnigan MAT Element high-resolution ICP-MS (at WHOI), by rapid peak-hopping using electrostatic scanning.

In-run precision for all but two of the measurements is $2 \sigma<0.35 \%$ for ${ }^{187} \mathrm{Os} /{ }^{188} \mathrm{Os}$, $2 \sigma<1 \%$ for Os and $2 \sigma<2 \%$ for Re contents. The exceptions are samples 83-107 and 83140 , with lower precision for Os concentration $(2 \sigma<10 \%)$ and isotopic composition ( $2 \sigma$ $<7 \%$ ), due to a large blank correction. The analytical blanks ranged from 0.4 to $0.5 \mathrm{pg} / \mathrm{g}$ of flux for Os and 5 to $24 \mathrm{pg}$ total blank for Re; the isotopic composition of the blank ranged from 0.4 to 0.47 for ${ }^{187} \mathrm{Os} /{ }^{188} \mathrm{Os}$. We used a ratio $1.5: 1$ of flux to sample. All samples were corrected for blank contribution. Re and Os replicates on separate powder splits ranged from 2 to $11 \%$ and from 1 to $18 \%$ respectively, excluding sample $85-106$, which showed a $32 \%$ difference for the Re replicate. The ${ }^{187} \mathrm{Os} /{ }^{188} \mathrm{Os}$ replicates for the Chudleigh xenoliths are $<0.6 \%$, but for the McBride suite, the replicates range from 2 to $5 \%$. The style of the poorer reproducibility in replicates from the McBride suite is suggestive of a "nugget" effect; that is, domains or minerals having higher $\mathrm{Re} / \mathrm{Os}$ are heterogeneously distributed within the rock and have been out of diffusive equilibrium with the rest of the rock for reasonably long time spans (in this case $300 \mathrm{Ma}$, the age of the suite; Rudnick and Williams, 1987). We consider high Re/Os nuggets as a possible explanation for the poor reproducibility in the $\mathrm{McBride}$ suite because the variation in ${ }^{187} \mathrm{Os} /{ }^{188} \mathrm{Os}$ ratios and Re contents is large, at similar Os concentrations (Table 1).

\subsection{Results}

The Os isotopic composition and Re and Os concentrations of sixteen samples from two well-characterized lower crustal xenolith suites from North Queensland are reported in Table 1. The two suites of xenoliths from Queensland show differences in $\operatorname{Re}$ and Os concentration and $\mathrm{Re} / \mathrm{Os}$ ratios, but have a similar and large range in ${ }^{187} \mathrm{Os} /{ }^{188} \mathrm{Os}$ ratios (from 0.1721 to 1.759 for McBride versus 0.1889 to 1.814 for Chudleigh) (Figure $1 \mathrm{a}$ and b). The McBride xenoliths have a larger range of Re (two orders of magnitude), and a smaller range of Os contents and $\mathrm{Re} / \mathrm{Os}$ ratios than the Chudleigh xenoliths (a factor of less than two, excluding one outlier). Moreover, the Os isotopic ratios of the McBride xenoliths do not correlate with $\mathrm{Re} / \mathrm{Os}$ ratios (Figure 1). These characteristics are consistent with the extreme lithologic and genetic diversity of the McBride xenoliths; as noted above, these range from paragneisses to mafic and felsic orthogneisses, formed during large-scale mixing between Proterozoic crust and basalts during late-Paleozoic $(\sim 300 \mathrm{Ma})$ convergent 
margin magmatism (Rudnick and Taylor, 1987; Rudnick and Goldstein, 1990; Rudnick 1990; Rudnick and Taylor, 1991; Kempton and Harmon, 1992).

In contrast, the Re-Os results for the Chudleigh xenoliths show a strikingly good linear correlation on a Re-Os isochron diagram, defining an apparent age of approximately $260 \mathrm{Ma}$ (Figure 2). However, relatively good positive correlations for present-day ${ }^{187} \mathrm{Os} /{ }^{188} \mathrm{Os}$ and $\delta^{18} \mathrm{O}, \mathrm{Pb}$, and $\mathrm{Sr}$ isotopic compositions, and negative correlations between ${ }^{187} \mathrm{Os} /{ }^{188} \mathrm{Os}$ and $\mathrm{Nd}$ isotopic ratios contradict the hypothesis that the Re-Os isochron array represents a real age (Figure 3). In particular, the positive correlation between ${ }^{187} \mathrm{Os} /{ }^{188} \mathrm{Os}$ and $\Delta 7 / 4 \mathrm{~Pb}$ (Hart, 1984) implies the existence of an old crustal component in the formation of the lower crust (Figure 3). These correlations between the different isotopes and ${ }^{187} \mathrm{Os} /{ }^{188} \mathrm{Os}$ ratios suggest that the variation in Os isotopes is not the result of ingrowth from $\mathrm{Re} / \mathrm{Os}$, but is produced by mixing or AFC processes, as proposed by earlier studies. These studies showed that the Chudleigh xenoliths are mafic in composition $\left(\mathrm{SiO}_{2}<51.2\right.$ wt\%), and showing good correlations between $\mathrm{Sr}, \mathrm{Nd}, \mathrm{Pb}$ and $\delta^{18} \mathrm{O}$ isotopic composition, trace element contents and $\mathrm{Mg}^{\#}$. These correlations reflect a genetically-related suite of cumulates from mafic magma(s) that underwent simultaneous assimilation and fractionation in the deep crust (Rudnick et al., 1986; Rudnick and Goldstein, 1990; Rudnick and Taylor, 1991; Kempton and Harmon, 1992). It is very unusual to find such simple chemical and isotopic systematics in lower crustal xenolith suites. The Chudleigh suite thus provides an unique natural laboratory with which to investigate the chemical changes occurring in mafic magmas that pond and fractionate within the deep continental crust.

\subsection{Discussion}

\subsubsection{The Re-Os composition of the lower continental crust}

The Chudleigh and McBride xenoliths have average major and trace element compositions similar to estimates of the bulk lower continental crust (Rudnick, 1992; Rudnick and Fountain, 1995) (Figure 4), and can therefore be used to place broad constraints on the Re-Os concentration and Os isotopic composition of the lower crust. The xenoliths have Os and Re concentrations which average 102 and $276 \mathrm{ppt}(\mathrm{Re} / \mathrm{Os}=$ $2.71)$, with median values of 49 and $184 \mathrm{ppt}(\mathrm{Re} / \mathrm{Os}=3.75)$ respectively (Table 1 , Figure 1). The average and the median are quite different because of one outlier (sample 85-100) with high Os $(\approx 1000 \mathrm{ppt})$ and $\operatorname{Re}(\approx 800 \mathrm{ppt})$ concentrations. The median values are 
probably more useful in representing the bulk lower crust, but more data are clearly desirable. The concentration-weighted mean ${ }^{187} \mathrm{Os} /{ }^{188} \mathrm{Os}$ ratio for the lower crust in north Queensland is 0.4 or 0.8 , including and excluding the outlier, respectively. Recent analyses of eclogite and granulite facies xenoliths from central Arizona by Esperança et al., (1997), give similar results (Table 1, Figure 1), although these xenoliths have somewhat lower Os contents, which translates into a slightly higher mean Re/Os ratio. We infer from these data that, relative to the upper crust (Esser and Turekian, 1993), the lower crust has one to two times as much Os, about half of the Re, and is probably less radiogenic (having one half to one third the ${ }^{187} \mathrm{Os} /{ }^{188} \mathrm{Os}$ of the upper crust). However, the Os isotopic composition of the lower continental crust will vary with the age of the crust. If we assume a mean age of $2.3 \mathrm{Ga}$ for the continental crust (Allègre et al., 1983) and the Re-Os composition of the mantle given by Meisel et al. (1996), and our average Re/Os estimates of $\cdot{ }^{187} \mathrm{Re}^{188} \mathrm{Os} \approx 20$ and 16 , respectively (including and excluding the data by Esperança et al. (1997), for the Arizona xenoliths), we calculate the mean ${ }^{187} \mathrm{Os} /{ }^{188} \mathrm{Os}$ of the bulk lower crust to be between 0.7 to 0.9 (Figure 1b), a range that encompasses the median Os isotopic composition derived from the Queensland xenoliths (Table 1). Importantly, our data establish the presence of material with relatively high Os contents and radiogenic Os isotopic compositions in the lower crust. The variation in Os isotopic composition and ReOs concentrations in all three xenolith suites illustrates the heterogeneity of the present lower crust, and shows that isotopic homogenization through fluid flow or melting has not been important.

\subsubsection{Chudleigh xenoliths}

\subsubsection{The Assimilation and Fractional Crystallization (AFC) model}

We model the Chudleigh xenoliths as cumulates resulting from simultaneous assimilation and fractional crystallization (DePaolo, 1981) of a basaltic melt in the deep continental crust (Figure 3d, e and f; modeling parameters are given in the figure caption). The sigmoidal shape of the curves in the ${ }^{187} \mathrm{Os} /{ }^{188} \mathrm{Os}$ versus $\mathrm{Sr}$ and $\mathrm{Nd}$ isotopes shows that during the first stages of AFC the Os isotopic composition is buffered by the Os content in the basaltic magma, whereas during the later stages it is buffered by the Os content and isotopic composition of the assimilant (old continental crust). The fractionation of olivine and/or sulfide decreases the concentration of Os in the magma (Hart and Ravizza, 1996), making it susceptible to contamination with crustal material having low Os concentration ( $2 \mathrm{ppt}$, in our model; Figure $3 \mathrm{~d})$. Notice that in the initial and final stages 
there is a decoupling between ${ }^{187} \mathrm{Os} /{ }^{188} \mathrm{Os}$ and the other isotopic systems. The compatible behavior of $\mathrm{Os}$ relative to $\mathrm{Nd}, \mathrm{Sr}$ and $\mathrm{Pb}$, and the differences in $\mathrm{Os}$ concentration and isotopic composition between mantle melts and evolved crustal materials, accounts for the buffering of Os in the melt; such effects are generally not observed in the other isotopic systems. Moreover, the compatible character of Os explains the large difference between the trends produced by AFC and bulk mixing (Figures 3), and makes AFC a far more effective process than bulk mixing for changing the isotopic composition of the basalt, especially when the contaminant has a low Os concentration.

\subsubsection{The age}

Although the Chudleigh xenoliths cannot be dated directly, the chemical systematics described above provide some constraints on their magmatic crystallization age. Because the xenoliths are cumulates, and not crystallized magmas, they exhibit a large range in $\mathrm{Sm} / \mathrm{Nd}$ ratio, depending upon whether plagioclase or clinopyroxene is the main cumulate phase. Thus the excellent correlations seen today between $\mathrm{Nd}$ isotopic composition $\left(\varepsilon_{\mathrm{Nd}}\right.$ from +9.6 to -6.1$), \mathrm{Mg} \#(63$ to 79$), \mathrm{Pb}\left({ }^{206} \mathrm{~Pb} /{ }^{204} \mathrm{~Pb}=17.8\right.$ to 18.7$), \mathrm{Sr}\left({ }^{87} \mathrm{Sr} /{ }^{86} \mathrm{Sr}=\right.$ 0.70239 to 0.71467$)$ and $\delta^{18} \mathrm{O}\left(\delta^{18} \mathrm{O}=+6.2\right.$ to +7.0$)$ degrade as the isotopic compositions are calculated at earlier times (Rudnick et al., 1986; Rudnick and Goldstein, 1990; Kempton and Harmon, 1992) (Figure 2, inset). These features led to the conclusion that the cumulates crystallized relatively recently $(<100 \mathrm{Ma})$, and that they are probably related to Cenozoic igneous activity that occurs throughout eastern Australia (Rudnick et al., 1986).

The Re-Os results for the Chudleigh xenoliths show a strikingly good linear correlation on a Re-Os isochron diagram, defining an apparent age of approximately 260 Ma (Figure 2). There are two possible interpretations for this correlation:

1) it accurately reflects the igneous crystallization age of the xenoliths.

2) it reflects a recent $\mathrm{AFC}$ process involving a mantle-like end member and a radiogenic crustal end member.

We prefer the second interpretation for the reasons outlined below.

Parental magmas in the xenolith suite underwent both crystallization (as evidenced by the cumulate textures and compositions) and crustal assimilation (as seen in the $\mathrm{Nd}, \mathrm{Sr}$, $\mathrm{Pb}, \delta^{18} \mathrm{O}$ isotopic systems, trace element and $\mathrm{Mg \#}$ systematics) (Rudnick et al., 1986; 
Rudnick and Goldstein, 1990; Kempton and Harmon, 1992). If interpretation 1 is correct, at $\approx 260 \mathrm{Ma}$ ago the samples should all have the same initial ${ }^{187} \mathrm{Os} /{ }^{188} \mathrm{Os}$, while the Re/Os and the other isotopic systems varied due to progressive contamination. Therefore, this hypothesis assumes that the Os isotopes were either completely immune to crustal assimilation, giving the isotopic composition of the initial melt, or they were homogenized to the isotopic composition of the contaminant. That means that $260 \mathrm{Ma}$ ago, the Os isotopes reflected in the initial or final stage of the sigmoidal curve produced during the AFC process (Figure 3). Neither case is true. The $\left({ }^{187} \mathrm{Os} /{ }^{188} \mathrm{Os}\right)_{260 \mathrm{Ma}}$ ratios of these xenoliths exhibit a large range, between 0.12 to 0.26 , and therefore are not uniform at 260 $\mathrm{Ma}$ as expected by interpretation 1 (Figure 5). Even in the case that we assume the initial $\left({ }^{187} \mathrm{Os} /{ }^{188} \mathrm{Os}\right)_{260 \mathrm{Ma}}$ for the xenoliths to be uniform, it would be required to be approximately $\approx 0.19$. This Os isotopic composition is either too high compared to modern mantle-derived basalts (cf. 0.1276 to 0.1565 ) or too low to represent old continental crust (cf. $\approx 1.9$ ). Another possibility is that the AFC event was not recent but occurred $260 \mathrm{Ma}$ ago and $\left({ }^{187} \mathrm{Os} /{ }^{188} \mathrm{Os}\right)_{260 \mathrm{Ma}}$ ratios were modified by contamination. If this would be the case, we would expect that the $\left({ }^{187} \mathrm{Os} /{ }^{188} \mathrm{Os}\right)_{260 \mathrm{Ma}}$ ratios would correlate with other indicators of contamination such as $\delta^{18} \mathrm{O}$ isotopes. Figure 5 shows that the initial Os isotope ratios do not correlate with any of the other isotopic systems at $\approx 260 \mathrm{Ma}$. Thus, it is unlikely that the apparent "age" of $260 \mathrm{Ma}$ is real, or that the mixing occured $260 \mathrm{Ma}$ ago. In contrast, relatively good positive correlations are seen for present-day ${ }^{187} \mathrm{Os} /{ }^{188} \mathrm{Os}$ and $\delta^{18} \mathrm{O}, \mathrm{Pb}$, and $\mathrm{Sr}$ isotopic compositions and negative correlations between ${ }^{187} \mathrm{Os} /{ }^{188} \mathrm{Os}$ and $\mathrm{Nd}$ isotopic ratios (Figure 3). The inset to Figure 2 shows that the correlations between different isotope systems, as measured by their correlation coefficient, are best within 50 to $100 \mathrm{Ma}$ of the present-day. The general lack of correlations between $\mathrm{Mg \#}$ and $\mathrm{Nd}, \mathrm{Pb}$ isotopes at $260 \mathrm{Ma}$ (Figure 2, inset), coupled with the relatively good present-day correlations (Figure 3), strongly suggests that these cumulates did not crystallize at $260 \mathrm{Ma}$ (Rudnick et al., 1986; Rudnick and Goldstein, 1990). We conclude that the positive trend in the Re-Os isochron diagram was produced by AFC processes at a later date.

Our AFC model not only explains the correlation between ${ }^{187} \mathrm{Os} /{ }^{188} \mathrm{Os}$ and the other isotopic ratios observed in the Chudleigh xenoliths (Figure 3d, e and f), it also reproduces the near-linear trend in the Re-Os isochron diagram (Figure 2), even when the contaminant does not lay on that trend. Our data and modelling show that AFC processes may produce 
whole-rock Re-Os isochrons with no age significance, by depletion of Os through olivinesulfide fractionation, coupled with assimilation of radiogenic crust.

\subsubsection{Continental basalts, mantle heterogeneity or lower crustal contamination?}

The Chudleigh xenoliths clearly document that the Os isotopic composition of basaltic magmas can be easily affected by crustal assimilation. Small amounts of AFC during basalt-lower continental crust interaction can produce Os isotopic variations that may be erroneously interpreted as evidence for mantle heterogeneity. For example, consider an $\mathrm{AFC}$ process involving basalts with a MORB signature $\left({ }^{187} \mathrm{Os} /{ }^{188} \mathrm{Os} \approx 0.1276\right.$, Os concentration ranging from 10 to $300 \mathrm{ppt}$; Roy-Barman and Allègre, 1995), interacting with the lower crust $\left({ }^{187} \mathrm{Os} /{ }^{188} \mathrm{Os} \approx 0.804, \mathrm{Os} \approx 50 \mathrm{ppt}\right)$. Figure 6 shows that it would require only 1 to $10 \% \mathrm{AFC}$, depending on the Os concentration of the basalts to change the isotopic composition of the melt from 0.1276 to 0.1565 , a value typical for a more enriched mantle source [using the most primitive OIB samples analyzed for Os isotopes (Hauri and Hart, 1993), and assuming a bulk $\mathrm{D}_{\mathrm{Os}} \approx 10$ (Hart and Ravizza, 1996), and a ratio of mass assimilated to mass fractionated of one half]. Thus, small extents of AFC processes

during basalt-lower crust interaction can produce isotopic variations in the melt that may be erroneously interpreted as evidence for mantle heterogeneity.

\subsection{Conclusions}

In summary, the lower crust has, on average, higher Os ( $\geq 2$ times) and lower $\operatorname{Re}$ concentrations than current estimates of the average upper crust and may thus be comparatively less radiogenic. Materials with relatively high Os concentrations and radiogenic Os isotopic compositions exist in the lower crust and may act as contaminants to basaltic magmas that differentiate there. The Re-Os system is extremely sensitive to AFC processes at relatively small degrees of differentiation (i.e., $<220 \%$ AFC) and AFC processes are more effective than bulk mixing in changing Os isotopic compositions of melts, due to Os depletion during fractional crystallization. Like other isotopic systems, the $\mathrm{Re}-\mathrm{Os}$ system is not a good indicator of the crystallization age of rocks that formed through AFC processes. 


\subsection{References}

Allègre, C. J., Hart, S. R. and Minster, J.F., Chemical structure and evolution of the mantle and continents determined by inversion of $\mathrm{Nd}$ and $\mathrm{Sr}$ isotopic data II. Numerical experiments and discussion. Earth Planet. Sci. Lett. 66, 191-213 (1983).

Allègre, C. J. and Luck, J.M., Osmium isotopes as petrogenetic and geological tracers. Earth Planet. Sci. Lett. 48, 148-154 (1980).

DePaolo D. J., Trace element and isotopic effects of combined wallrock assimilation and fractional crystallization. Earth Planet. Sci. Lett. 53, 189-202 (1981).

Esperança S., Carlson R. W. and Shirey S. B., Dating crust-mantle separation: Re-Os isotopic study of mafic xenoliths from central Arizona. Geology 25, 651-654 (1997)

Esser, B. K. and Turekian, K. K., The osmium isotopic composition of the continental crust. Geochim. Cosmochim. Acta 57, 3093-3104 (1993).

Halliday, A. H., Dickin A. P., Hunter, R. N., Davies, G. R., Dempster T. J., Hamilton, P. J. and Upton B. G. J., Formation and Composition of the lower continental crust: Evidence from Scottish xenolith suites. J. Geophys. Res. 98/B1, 581-607 (1993).

Hart, S. R., A large-scale isotopic anomaly in the Southern Hemisphere mantle. Nature 309, 753-757 (1984).

Hart S. R. and Ravizza G. E., Os partitioning between phases in lherzolite and basalt. In: Earth Processes: Reading the Isotopic Code (eds. Basu A. and Hart S.R) AGU Monograph 95, 123-134 (Washington: American Geophysical Union, 1996).

Hauri E. H. and Hart S. R., Re-Os isotope systematics of HIMU and EMII oceanic island basalts from the south Pacific ocean. Earth Planet. Sc. Lett. 114: 353-371, 1993.

Horan, M. F., Walker, R. J., Fedorenko, V. A. and Czamanske, G. K., Osmium and neodymium isotopic constraints on the temporal and spatial evolution of Siberian flood basalt sources. Geochim. Cosmochim. Acta 59, 5159-5168 (1995).

Kempton, P. D. and Harmon, R. S., Oxygen isotope evidence for large-scale hybridization of the lower crust during magmatic underplating. Geochim. Cosmochim. Acta 56, 971-986 (1992).

Lambert, D. D., Morgan, J. W., Walker, R. J., Shirey, S. B., Carlson, R. W., Zientek, M. L. and Koski, M. S., Re-Os and Sm-Nd systematics of the Stillwater complex. Science 244, 1169-1174 (1989).

Marcantonio, F., Zindler, A., Elliot, T. R. and Staudigel, H., Os isotope systematics of La Palma, Canary Islands: evidence for recycled crust in the mantle source of HIMU ocean island. Earth Planet. Sci. Lett. 133, 397-410 (1995). 
Marcantonio, F., Zindler, A., Reisberg, L. C. and Mathez E. A., Re-Os isotope systematics in chromitites from Stillwater complex. Geochim. Cosmochim. Acta 57, 4029$4037(1993)$

Martin, C. E., Carlson, R. W., Shirey, S. B., Frey, F. A. and Chen, C. Y., Os isotopic variation in basalts from Haleakala volcano, Maui, Hawaii; a record of magmatic processes in oceanic mantle and crust. Earth Planet. Sci. Lett. 128, 287-301 (1991).

Martin, C. E., Re-Os isotopic investigation of the Stillwater complex, Montana. Earth Planet. Sci. Lett. 93, 336-344 (1989).

Meisel, T., Walker, R. J. and Morgan, J. W., The osmium isotopic composition of the Earth's primitive upper mantle. Nature 383, 517-520 (1996).

Peucker-Ehrenbrink, B., Ravizza, G. E. and Hofmann, A. W., The marine ${ }^{187} \mathrm{Os} /{ }^{188} \mathrm{Os}$ record of the past 80 million years. Earth Planet. Sci. Lett. 130, 155-167 (1995).

Ravizza G. and Turekian K. K., Applications of the 187Re-187Os system to black shale geochronology. Geochim Cosmochim. Acta, 53: 3257-3262, 1989.

Reisberg, L. C., Zindler, A., Marcoantonio, F., White, W. M., Wyman, D. A. and Weaver, B.L., Os isotope systematics in ocean island basalts. Earth Planet. Sci. Lett. 120, 149-167 (1993).

Rudnick, R. L., McDonough, W. F., McCulloch, M. T. and Taylor, S. R., Lower crustal xenoliths from Queensland, Australia: evidence for deep crustal assimilation and fractionation of continental basalts. Geochim. Cosmochim. Acta 50, 1099-1115 (1986).

Rudnick, R. L. and Taylor, S. R., The composition and petrogenesis of the lower crust: a xenolith study. J. Geophys. Res. 92/B13, 13,981-14,005 (1987).

Rudnick, R. L. and Williams, I. S., Dating the lower crust by ion microprobe. Earth Planet. Sci. Lett. 85, 145-161 (1987).

Rudnick, R. L. and Goldstein, S.L., The Pb isotopic compositions of lower crustal xenoliths and the evolution of the lower crustal Pb. Earth Planet. Sci. Lett. 98, 192-207 (1990).

Rudnick, R. L., Nd and Sr isotopic compositions of lower crustal xenoliths from North Queensland, Australia: implications for $\mathrm{Nd}$ model ages and crustal growth processes. Chem. Geol. 83, 195-208 (1990).

Rudnick, R. L. and Taylor, S. R., Petrology and Geochemistry of lower crustal xenoliths from northern Queensland and inferences on lower crustal composition. In: The Australian Lithosphere (ed. Drummond B.). Geol. Soc. Aust. Spec. Publ. 17, 189-208 (1991).

Rudnick, R. L., Xenoliths - Samples of the lower continental crust. In: The Continental Lower Crust (eds. Fountain, D. M., Arculus, R. and Kay, R.) 269-316 (Elsevier, Amsterdam, 1992). 
Rudnick, R. L. and Fountain, D. M., Nature and composition of the continental crust: a lower crustal perspective. Rev. Geophys. 33, 267-309 (1995).

Rudnick, R. L., Making continental crust. Nature 378, 571-578 (1995).

Rudnick, R. L. and Presper, T., Geochemistry of intermediate to high-pressure granulites, in Granulites and Crustal Evolution, Vielzeuf, D. and Vidal, P. (eds.) 523-550, Kluwer Acad., Norwell, Mass., (1990).

Roy-Barman, M. and Allègre, C. J., ${ }^{187} \mathrm{Os} /{ }^{188} \mathrm{Os}$ in oceanic island basalts: tracing crust recycling in the mantle. Earth Planet. Sci. Lett. 129, 145-161 (1995).

Taylor S. R. and McLennan, S. M., The geochemical evolution of the continental crust. Rev. Geophys. 33, 241-265 (1995).

Walker, R. J., Morgan, J. W., Hanski, E. J. and Smolkin, V. F., Re-Os systematics of early Proterozoic ferropicrites, Pechenga Complex, NW Russia: evidence for ancient ${ }^{187} \mathrm{Os}-$ enriched plumes. Geochim. Cosmochim. Acta 61,3145-3160 (1997).

Walker, R. J., Morgan, J. W., Naldrett, A. J., Li, C. and Fassett J. D., Re-Os isotope systematics of $\mathrm{Ni}-\mathrm{Cu}$ sulfide ores, Sudbury igneous complex: Evidence for a major crustal component. Earth Planet. Sci. Lett. 105, 416-429 (1991).

Walker, R. J., Morgan, J. W., Horan, M. F., Czamanske, G. K., Krogstad, E. J., Fedorenko, V. A. and Kunilov V. E., Re-Os isotopic evidence for an enriched-mantle source for the Noril'sk-type, ore-bearing intrusions, Siberia. Geochim. Cosmochim. Acta 58, 4179-4197 (1994).

Widom, E. and Shirey, S. B., Os isotope systematics in the Azores: implications for mantle plume sources. Earth Planet. Sci. Lett. 142, 451-465 (1991).

Zandt, G. and Ammon, C. J., Continental crust composition constrained by measurements of crustal Poisson's ratio. Nature 374, 152-154 (1995).

NOTE: This chapter is based on an already published work: Saal A. E., Rudnick R.L., Ravizza G. E. and Hart S. R., Re-Os isotope evidence for the composition, formation and age of the lower continental crust. Nature 393, 58-61 (1998). 


\subsection{Table Caption}

Table 1: Re, Os concentration and Os isotopic composition for the Chudleigh and McBride xenolith suites. * indicates samples and replicate that were run on the same day. $\mathrm{T}_{\text {OSPUM }}$ are Os model ages calculated with respect to "bulk earth" $\left({ }^{187} \operatorname{Re} /{ }^{188} \mathrm{Os}=0.428\right.$ and ${ }^{187} \mathrm{Os} /{ }^{187} \mathrm{Os}=0.1290$; Meisel et al. (1996) and a decay constant of $1.64 \times 10^{-11} \mathrm{y}^{-1} . \mathrm{PI}=$ plagioclase and $\mathrm{Px}=$ pyroxene. Average and median values for the Arizona suite (Esperança et al, 1997) and average values for the upper continental crust (Esser and Turekian, 1993) are also reported. In some samples, we report duplicates for Re, but we measured the Os concentration and ${ }^{187} \mathrm{Os} /{ }^{188} \mathrm{Os}$ ratios only once. In those cases, we calculate the ${ }^{187} \operatorname{Re} /{ }^{188} \mathrm{Os}$ and the Os model ages twice, using both Re values and the measured Os concentration and isotopic composition.

\subsection{Figure Captions}

Figure 1: a) Os versus Re concentrations, and b) $\mathrm{Re} / \mathrm{Os}$ versus ${ }^{187} \mathrm{Os} /{ }^{188} \mathrm{Os}$ ratios for lower crustal xenoliths from Queensland, Australia. The two mean lower crustal isotopic compositions shown in panel $\mathrm{b}$ are weighted according to Os concentrations. The lower square includes an anomalously high Os sample, the upper square excludes this sample. Fields for upper continental crust (without organic and carbonate-shelf sediments) and oceanic basalts (MORB-OIB) were compiled by Bernhard Peucker-Ehrenbrink. The mean and median $\mathrm{Re}$ and Os concentration, Re/Os ratios and isotopic composition weighted by Os concentration for Arizona xenoliths (Esperança et al, 1997) are plotted for comparison. The McBride xenoliths show chemical characteristics indicative of a lithologically and genetically diverse suite, and plot in the field defined by upper crustal material. The Chudleigh suite shows characteristics of genetically-related cumulates from basaltic magma undergoing crustal contamination (see text).

Figure 2: Re-Os isochron diagram for the Chudleigh suite showing bulk mixing and AFC trends. The data (solid circles) define a linear trend, with an apparent age of $\approx 260 \mathrm{Ma}$. Open circles are duplicate analyses, not included in the isochron regression. The inset shows correlation coefficients (for linear correlations) between $\mathrm{Mg \# ,} \mathrm{Nd}\left({ }^{143} \mathrm{Nd} /{ }^{144} \mathrm{Nd}\right.$ ) and $\mathrm{Pb}\left({ }^{206} \mathrm{~Pb} /{ }^{204} \mathrm{~Pb}\right)$. In contrast to the Re-Os age, the best correlations exist at $<100 \mathrm{Ma}$, suggesting that the crystallization age of these xenoliths was $<100 \mathrm{Ma}$. The AFC model (using the parameters listed in Figure 3 caption) generates a linear trend in the Re-Os 
diagram (shown by gray circles), which has no age significance. $X$ 's show the bulk mixing trend between the initial melt and the assimilant used in the AFC model. Each gray circle and $\mathrm{X}$ corresponds to $5 \% \mathrm{AFC}$ or bulk mixing, respectively. The York regression for the AFC model was calculated using the same number of points and same distribution in the isochron as the Chudleigh suite, to make the results comparable (the points used are labeled, i.e., 3\%). Note that the Chudliegh xenoliths are cumulates, producing low $\mathrm{Re} / \mathrm{Os}$ ratios during the $\mathrm{AFC}$ process. Figures 2, 3 and 6 indicate that careful evaluation of $\mathrm{AFC}$ is necessary before age significance is attributed to Re-Os isochrons for lower crustal xenoliths or for basalts (or their cumulates) that may have differentiated in the lower continental crust.

Figure 3: Isotopic correlations and AFC model results for the Chudleigh xenoliths (black circles). ${ }^{187} \mathrm{Os} /{ }^{188} \mathrm{Os}$ versus a) ${ }^{206} \mathrm{~Pb} /{ }^{204} \mathrm{~Pb}$, b) $\Delta 7 / 4 \mathrm{~Pb}$, c) $\delta^{18} \mathrm{O}$, d) Os concentration, e) ${ }^{143} \mathrm{Nd} /{ }^{144} \mathrm{Nd}$ and f) ${ }^{87} \mathrm{Sr} /{ }^{86} \mathrm{Sr}$. Relatively good correlations exist between ${ }^{187} \mathrm{Os} /{ }^{188} \mathrm{Os}$, Os concentration and $\mathrm{Pb}, \mathrm{Sr}, \mathrm{Nd}, \mathrm{Pb}, \delta^{18} \mathrm{O}$ isotopic systems, with the exception of one sample. The aberrant sample (83-114, open circle) is probably showing a "nugget" effect; this explanation is consistent with this sample having the lowest Os isotopic ratios and the highest Os concentration, and plotting outside the correlation defined by the other samples. The AFC curves (gray circles) are marked in 5\% increments (except the labeled points), where the ratio of mass assimilated to mass fractionated is $\approx 0.67$. The contaminant has intermediate $\mathrm{Sr}$ and $\mathrm{Nd}$ isotopic compositions $\left({ }^{87} \mathrm{Sr} /{ }^{86} \mathrm{Sr} \approx 0.75\right.$ and $\left.{ }^{143} \mathrm{Nd} /{ }^{144} \mathrm{Nd} \approx 0.5114\right)$ and elemental concentrations $(\mathrm{Sr} \approx 200 \mathrm{ppm}, \mathrm{Nd} \approx 27 \mathrm{ppm}$ ), based on published data for crust from the Tasman fold belt (Rudnick et al, 1986). This crustal contaminant is assumed to have very low $\mathrm{Os}(\approx 2 \mathrm{ppt})$, to test the sensitivity of Os to crustal contamination, and $\mathrm{Re}$ concentrations $(\approx 24 \mathrm{ppt})$, and ${ }^{187} \mathrm{Os} /{ }^{188} \mathrm{Os} \approx 2.6477\left(\mathrm{~T}_{\mathrm{OsCH}} \approx 2 \mathrm{Ga}\right.$.), similar to Proterozoic upper continental crust. All of the isotope systems (e.g., $\mathrm{Sr}, \mathrm{Nd}, \mathrm{Pb}, \delta^{18} \mathrm{O}$ and $\mathrm{Os}$ ) require a contaminant that is higher in $\delta^{18} \mathrm{O}, \Delta 7 / 4 \mathrm{~Pb}, \mathrm{Sr}, \mathrm{Pb}$ and $\mathrm{Os}$ and lower in $\mathrm{Nd}$ isotopic composition than any sample seen in either the Chudleigh or McBride xenolith suites; this suggests the presence in the lower crust of (unsampled) old material with high $\delta^{18} \mathrm{O}$ and high time-integrated $\mathrm{Rb} / \mathrm{Sr}, \mathrm{U} / \mathrm{Pb}$ and $\mathrm{Re} / \mathrm{Os}$ and low $\mathrm{Sm} / \mathrm{Nd}$. For the parental basaltic melt, we used the most primitive isotopic composition seen in the xenoliths $\left({ }^{87} \mathrm{Sr} /{ }^{86} \mathrm{Sr} \approx 0.702,{ }^{143} \mathrm{Nd} /{ }^{144} \mathrm{Nd} \approx 0.5131\right)$ and inferred ${ }^{187} \mathrm{Os} /{ }^{188} \mathrm{Os} \approx 0.1276$. We assumed this melt has $\mathrm{Sr} \approx 350 \mathrm{ppm}, \mathrm{Nd} \approx 14 \mathrm{ppm}, \mathrm{Re} \approx 250 \mathrm{ppt}$, and 7.5 times the Os concentration of the contaminant $(\approx 15 \mathrm{ppt})$. Bulk partition coefficients for $\mathrm{Sr}$ and $\mathrm{Nd}$ were 
estimated assuming cumulates of plagioclase + clinopyroxene + olivine $\left(\mathrm{D}_{\mathrm{Sr}} \approx 0.5, \mathrm{D}_{\mathrm{Nd}} \approx\right.$ 0.1 ). The bulk partition coefficient for Os $\left(D_{\mathrm{Os}} \approx 7\right)$, was estimated from the data of Hart and Ravizza, (1996); Re was assumed to be moderately incompatible $\left(\mathrm{D}_{\mathrm{Re}} \approx 0.6\right)$. The AFC model presented here is not unique, but serves to illustrate that the trends observed in the data can be explained by an AFC process. In contrast, the same is not true for bulk mixing, which is not successful in reproducing the observed arrays.

Figure 4: Comparison between the mean major and trace elements composition of global lower crustal xenoliths with those from the Queensland xenoliths. The global dataset (available on http://www-ep.es.llnl.gov/germ/) includes 450 analyses of major elements and 150 analyses of trace elements, excluding the Queensland data. Both means for a variety of elements agree within the standard errors $(2 \sigma)$ of the compilations, suggests that the global average is a reasonable estimate of lower crust composition. The exception are $\mathrm{Cs}, \mathrm{Th}, \mathrm{U}, \mathrm{Pb}, \mathrm{Cu}$ and $\mathrm{Zn}$, difference that we attribute to their mobility during secondary processes and to the difficulty in their accurate measurement. The fact that many lower crustal xenoliths are demonstrably older than the magmatic episode that carried them to the surface indicates that the xenoliths are not genetically relatated to that magmatic event (Rudnick, 1992).

Figure 5: $\quad\left({ }^{187} \mathrm{Os} /{ }^{188} \mathrm{Os}\right)_{260 \mathrm{Ma}}$ versus $\left({ }^{206} \mathrm{~Pb} /{ }^{204} \mathrm{~Pb}\right)_{260 \mathrm{Ma}}, \quad\left({ }^{143} \mathrm{Nd} /{ }^{144} \mathrm{Nd}\right)_{260 \mathrm{Ma}}$, and $\left({ }^{87} \mathrm{Sr} /{ }^{86} \mathrm{Sr}\right)_{260 \mathrm{Ma}},{ }^{187} \mathrm{Re} /{ }^{188} \mathrm{Os}$ and $\delta^{18} \mathrm{O}$. Note that the present-day correlation between the isotopes is lost when they are corrected back to $260 \mathrm{Ma}$, indicating that the AFC processes did not occur $260 \mathrm{Ma}$ ago. Moreover, the xenoliths exhibit a large range in $\left({ }^{187} \mathrm{Os} /{ }^{188} \mathrm{Os}\right)_{260 \mathrm{Ma}}$ from 0.12 to 0.26 ; this variability would not be expected if the linear trend produced by the Chudleigh xenoliths in the Re-Os isochron diagram define a real age of $260 \mathrm{Ma}$ (see text for discussion).

Figure 6: ${ }^{187} \mathrm{Os} /{ }^{188} \mathrm{Os}$ versus extent of differentiation during an AFC process. This is a hypothetical case where we evaluate how much differentiation it would take for a MOR basalt interacting with the lower crust to give Os isotopic ratios similar to those measured in OIBs. We assumed for MORB ${ }^{187} \mathrm{Os} /{ }^{188} \mathrm{Os} \approx 0.1276$, and an Os concentration ranging from 10 to $300 \mathrm{ppt}$. We used our average Os values for the lower crust $\left({ }^{187} \mathrm{Os} /{ }^{188} \mathrm{Os} \approx\right.$ 0.804 , Os $\approx 50 \mathrm{ppt}$ ). We also assumed that the ratio between mass assimilated and mass fractionated is equal to 0.5 and the bulk partition coefficient for $\mathrm{Os}$ is $\mathrm{D}_{\mathrm{Os}} \approx 10$. Symbols are given at every $1 \%$ of AFC. Thus, it would require only 1 to $10 \% \mathrm{AFC}$, depending on 
the initial basalt Os concentration, to change the MORB Os isotopic composition of 0.1276 to that of OIBs $\approx 0.1565$. 
Table 1: $\operatorname{Re}$ and $O$ s concentrations and $O$ s isotopic compositions of granulite-facies lower crustal xenolith suites from Northern Queensland, Australia.

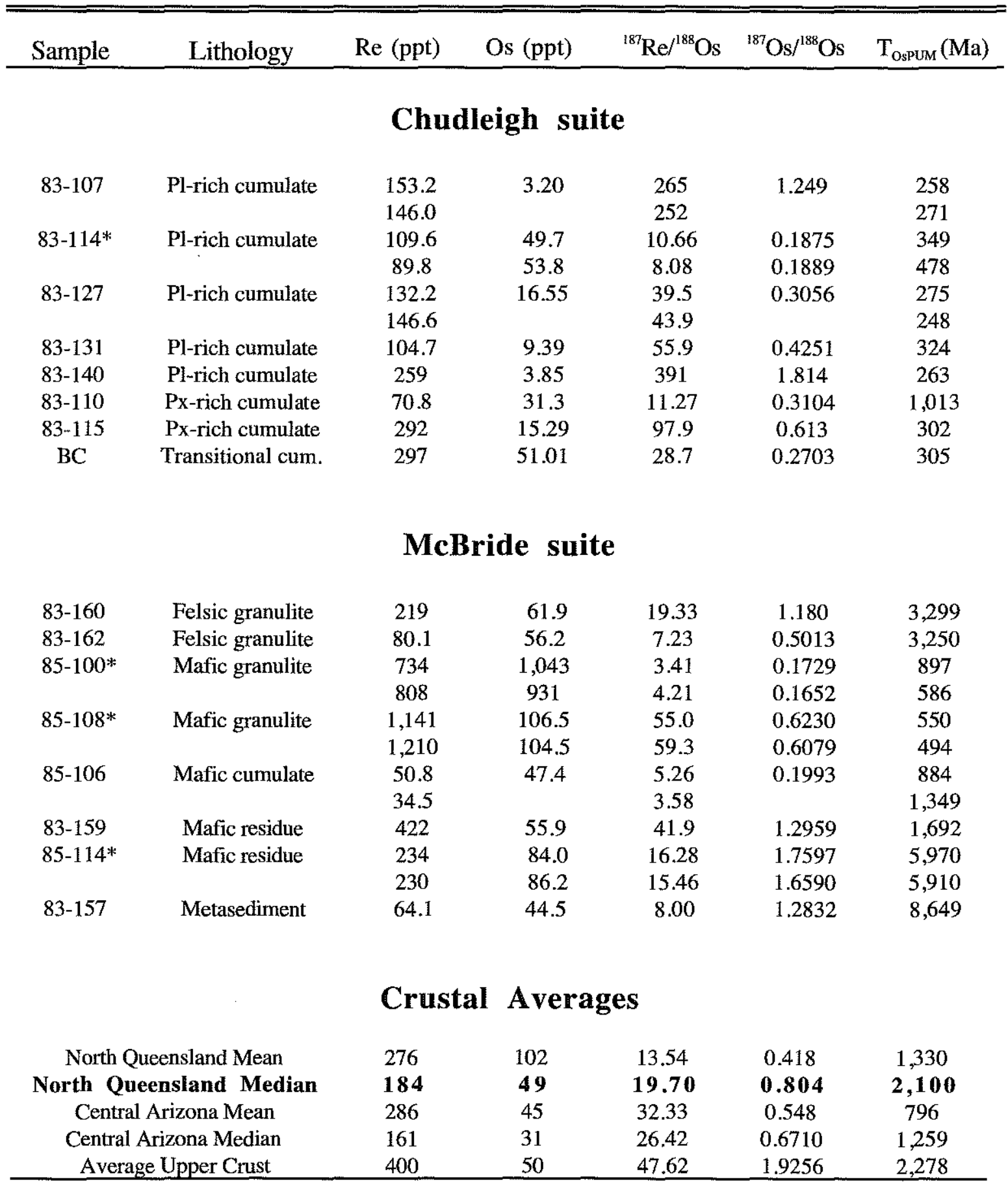



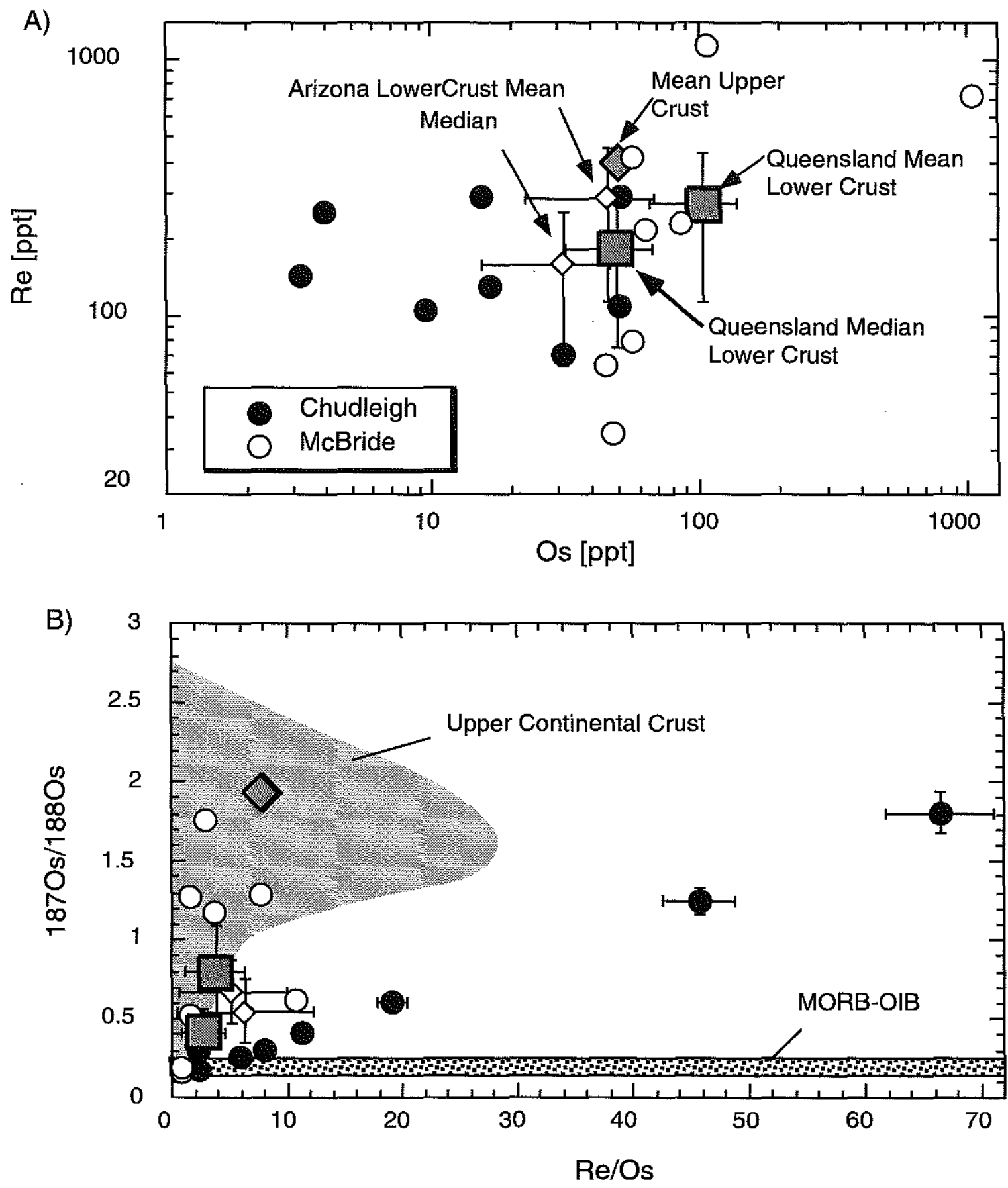

Figure 1 


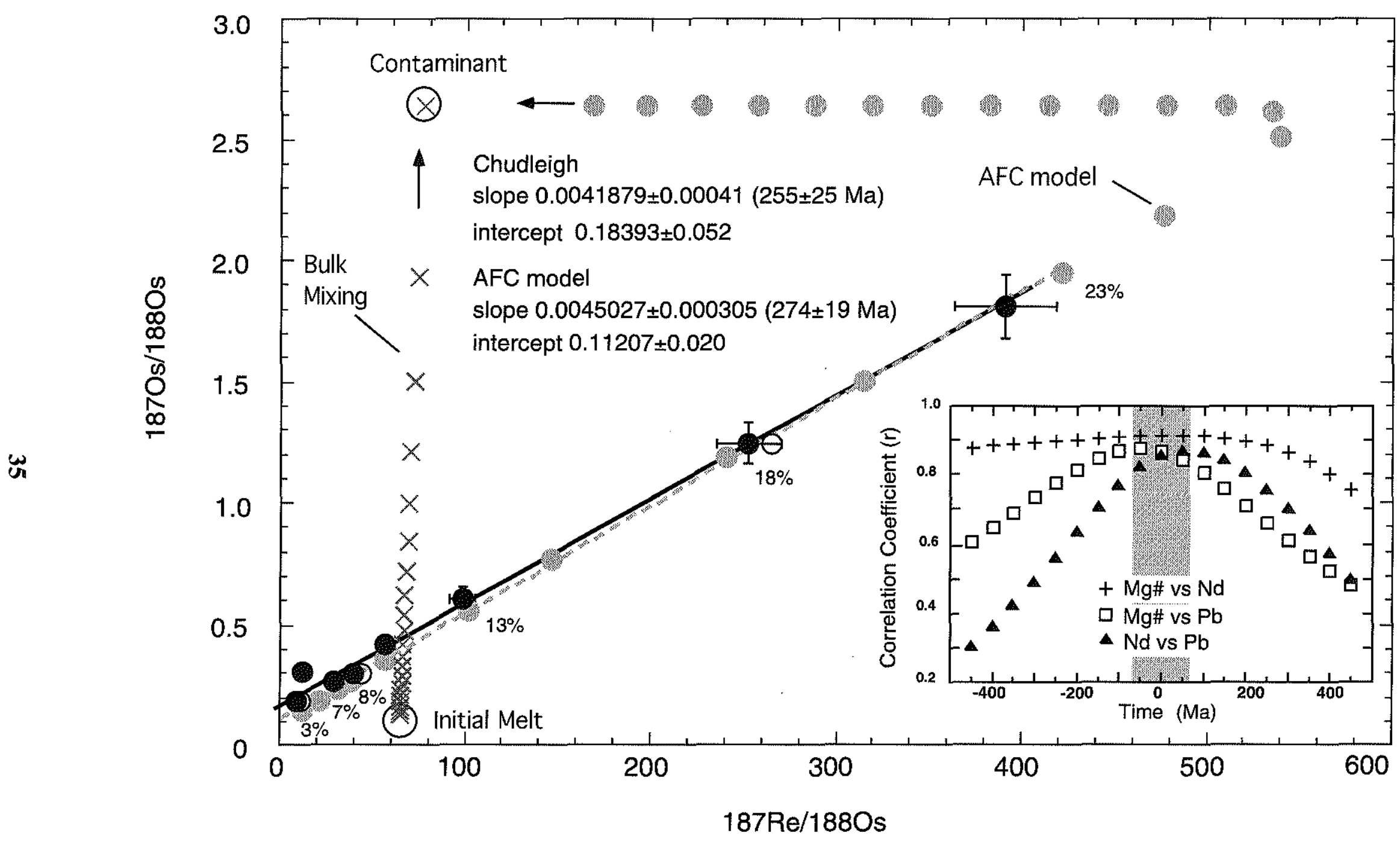

Figure 2 

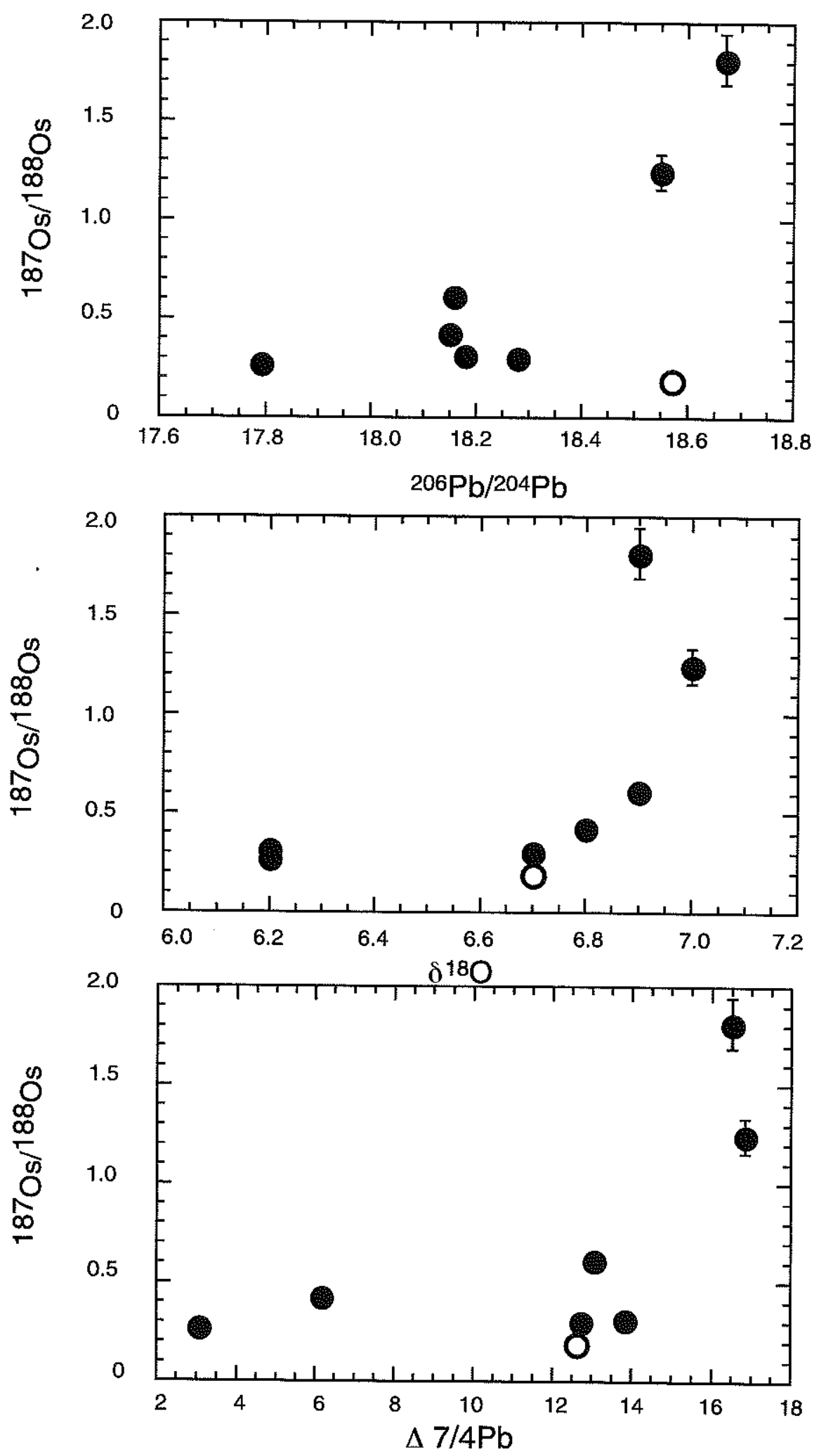

Figure 3 

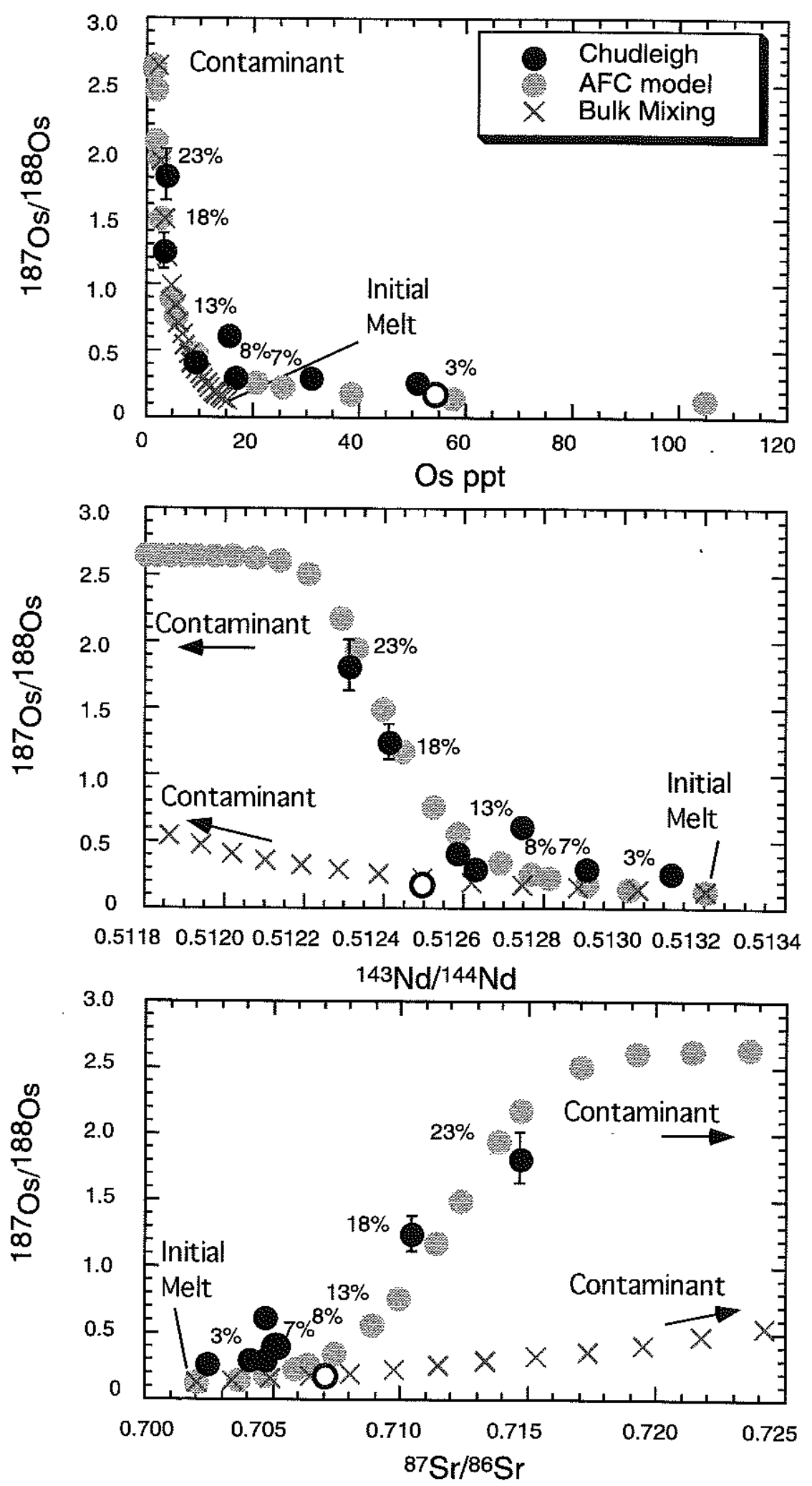

Figure 3 continuation 


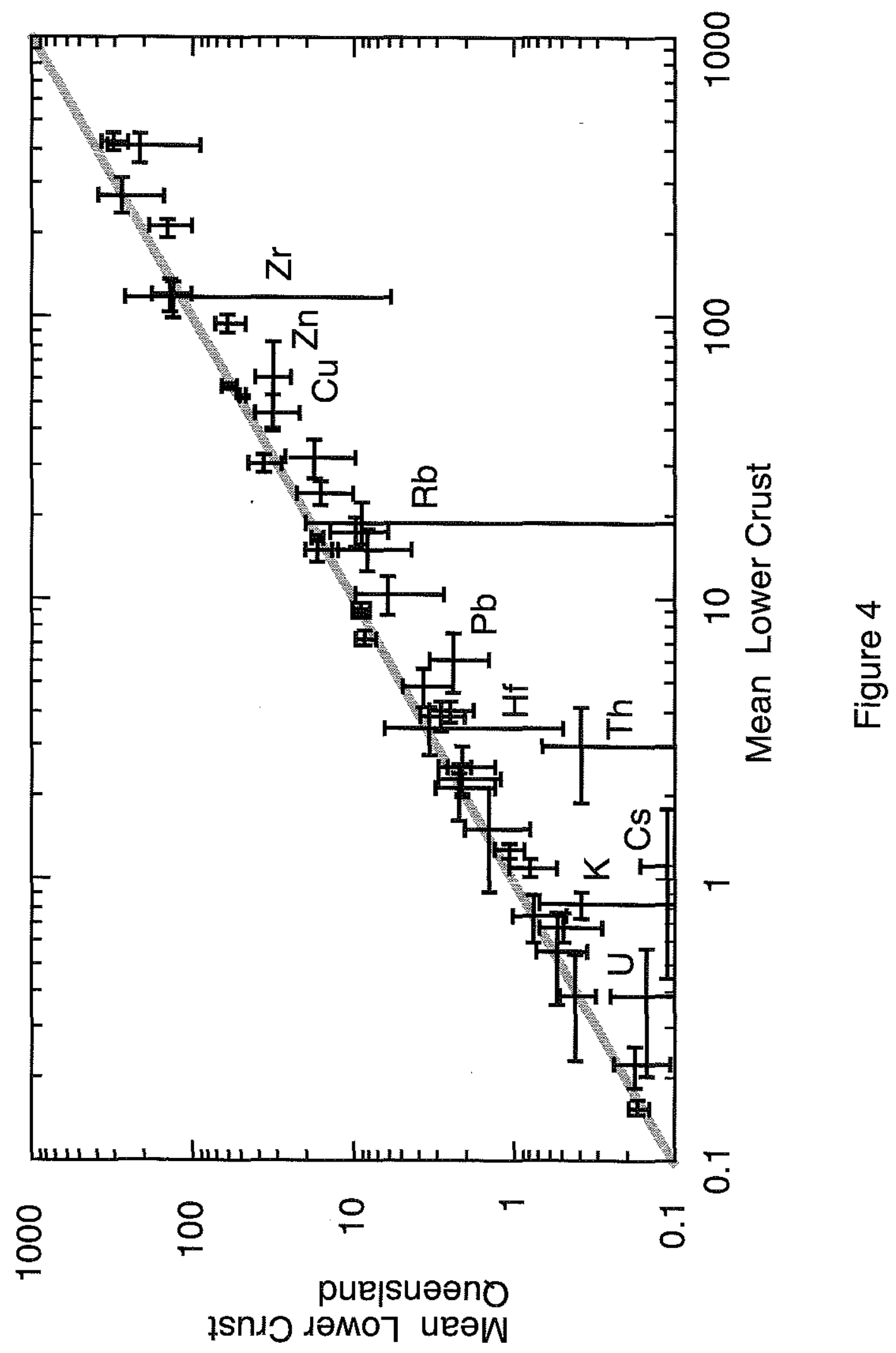



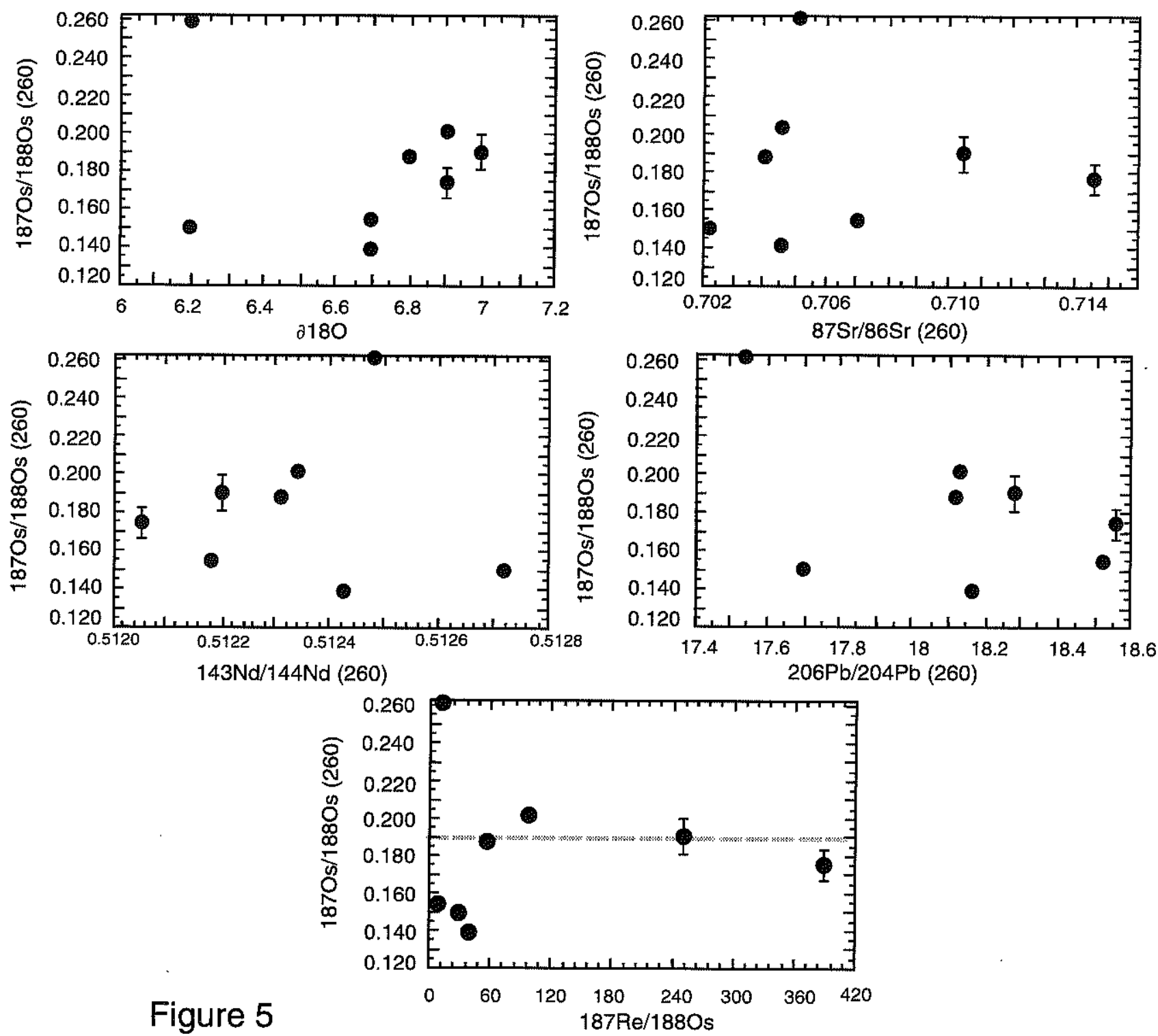

Figure 5 
AFC: Basalt-Lower Crust interaction

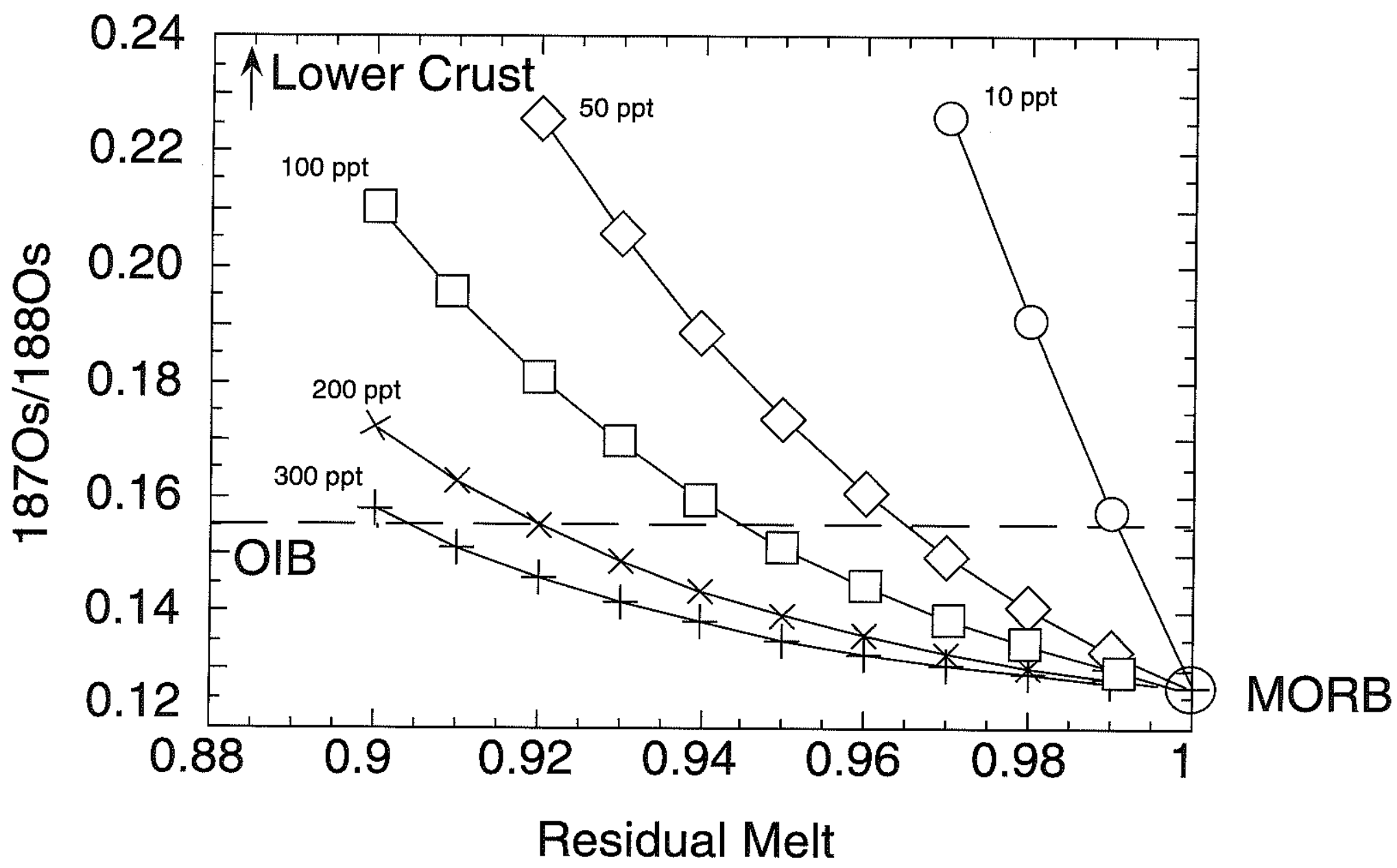

Figure 6 


\section{Chapter Two}

\section{Re-Os isotopic composition of the Horoman peridotite: Implications for the genesis of the Plagioclase Lherzolite and the layered structure}

\subsection{Abstract}

We report the Re-Os isotopic composition of the Horoman peridotite. Twenty samples were analyzed from a geochemically well-characterized 140-m section across the layered sequence ranging from plagioclase therzolite to lherzolite to harzburgite (the Bozu section). The range in ${ }^{187} \mathrm{Os} /{ }^{188} \mathrm{Os}$ ratios observed in the $140-\mathrm{m}$ Bozu section is similar to that reported for other peridotitic massifs, suggesting that the process(es) responsible for the Re-Os isotope variation at the meter or the whole massif scales are the same. The Re-Os isotope systematics in the Horoman peridotite indicate that the Os isotope composition is controlled by the Re content, through radiogenic ingrowth, while the Re content is governed by the extent of depletion in "basaltic component" of the ultramafic rocks. Re depletion model ages of $\approx 1.8 \mathrm{Ga}$ suggest that the age of melting is much older than $\approx 1$ $\mathrm{Ga}$, previously estimated based on $\mathrm{Nd}$ isotopes. However, the colinearity of data for mafic layers and the ultramafic samples in a Re-Os isochron diagram defines an apparent age of $\approx$ $1 \mathrm{Ga}$, similar to the ages defined by $\mathrm{Nd}$ isotopes. The colinearity between mafic and ultramafic rocks, the similar "ages" determined by Re-Os and Sm-Nd isotopes and the high $\mathrm{Re} / \mathrm{Os}$ ratios in the most fertile peridotites plotting to the right of the geochron, indicate that the mafic layers and the ultramafic rocks are genetically related by a refertilization process which took place $\approx 1 \mathrm{Ga}$ ago. The Re-Os systematics for other peridotite massifs indicate that refertilization of the lithospheric mantle seems to be a more widespread process than previously thought. Confirmation of the refertilization hypothesis could have important implications for our understanding of how the continental lithosphere forms and grows.

\subsection{Introduction}

The Horoman peridotite is a fault-bounded mantle slice, $8 \times 10 \times 3 \mathrm{~km}$, emplaced in the southern end of the high-temperature low-pressure Hidaka Metamorphic Belt in 
Hokkaido, Japan (Niida, 1974; 1984). The Horoman massif has been the subject of numerous structural, petrologic and geochemical studies (Nagasaki, 1966; Komatsu and Nochi, 1966; Niida, 1974; 1984; Arai and Takahashi, 1989; Obata and Nagahara, 1987; Takahashi et al., 1989; Takahashi, 1991; 1992; Ozawa and Takahashi, 1995; Frey et al, 1991, Takahashi and Arai, 1989; Takazawa et al., 1992; 1994; 1996, 1999a, 1999b; Takazawa 1996; Yoshikawa et al., 1993; Yoshikawa and Nakamura, 1998; Morishita and Kodera, 1998). However, the process (or processes) responsible for the formation of the layering, as well as the origin of the fertile plagioclase lherzolite, still remains controversial.

Several hypotheses have been proposed to explain the formation of the layering:

1) polybaric melting of an upwelling fertile mantle (plagioclase lherzolite), followed by subsolidus thinning and folding of large-scale simple compositional bands (Takazawa, 1996; Yoshikawa and Nakamura, 1999)

2) formation of cumulates through fractional crystallization (Niida, 1984).

3) melting and melt segregation of an homogeneous mantle, where the depleted rocks represent residues of melting and the plagioclase lherzolite represents the region of melt accumulation (Obata and Nagahara, 1987)

4) melt segregation processes governed by suction associated with local melting along a fracture, during continuous ascent of a mantle peridotite (Takahashi, 1992).

In summary, the origin of the layered structure has been explained either by melt depletion processes or by a combination of melting and melt accumulation. Thus, depending on the model considered, the plagioclase lherzolite has been considered as an unmelted section of a fertile peridotite or as a region of melt accumulation.

The Re-Os isotope system provides a unique view of mantle processes. Parent and daughter elements for other isotopic systems, ( $\mathrm{Rb}-\mathrm{Sr}, \mathrm{Sm}-\mathrm{Nd}$ and $\mathrm{U}-\mathrm{Pb}$ ) behave incompatibly during mantle melting, being mainly controlled by silicate phases. In contrast, Re behaves as a moderately incompatible element, while Os is highly compatible during melting, and both $\mathrm{Re}$ and Os have chalcophile and siderophile affinities (Walker et al., 1989; Reisberg et al., 1991; Luck and Allègre, 1991; Martin, 1991; Carlson and Irving, 1994; Hart and Ravizza, 1997; Shirey and Walker, 1997, Handler et al., 1997, Burton et al., 1998). Consequently, mantle peridotites have high Os concentrations, and this is 
presumed to make the Os isotope system more resistant to young metasomatic disturbances than the other isotopic systems. Thus, Re-Os isotope systematics can be a more reliable indicator of processes such as melting in peridotitic massifs than $\mathrm{Sr}, \mathrm{Nd}$ and $\mathrm{Pb}$ isotopes (Reisberg et al., 1991; Luck and Allègre, 1991; Reisberg and Lorand, 1995; Roy Barman et al., 1996; Burnham et al., 1998).

The long term goal of studying the continental mantle lithosphere is to date and deconvolve the superimposed effects of processes responsible for the geochemical variations found in the peridotite massif. To deconvolve the complex history of peridotitic massif is one of the few avenues availables to investigate the percolation and extraction of melts from the mantle. In this paper we report Re-Os isotope data for the Horoman peridotite. We selected a geochemically well-characterized $140 \mathrm{~m}$ section across the layered peridotite with rock types ranging from plagioclase lherzolite to lherzolite to harzburgite (the Bozu section); two mafic layers were also included. Takazawa and co-workers have studied this section and the mafic layers from the Horoman massif in detail, reporting major, trace element and isotopic compositions of whole rocks and mineral separates (Takazawa, 1996; Takazawa et al., 1992a; 1992b; 1993; 1994; 1995; 1996, 1999a, 1999b). The main objective of this work is to determine the origin of the plagioclase lherzolites (unmelted fertile peridotite or a region of melt impregnation and accumulation?) and the role played by the mafic layers.

\subsubsection{Geological Background}

The Horoman peridotite is a massif tectonically emplaced in the south-western tip of the high-temperature low-pressure Hidaka metamorphic belt, Hokkaido, Japan (Figure 1). To the west, the Horoman ultramafic complex is in fault contact with an peridotite section composed of greenschist to amphibolite-facies metamorphic rocks (Miyashita, 1983; Komatsu et al., 1994). To the east and south, the massif is in tectonic contact with a metamorphic sequence, ranging from biotite-schists to granulites, and intruded by granitoids, and representing a continental or island arc crustal section (Komatsu and Nochi, 1966; Niida, 1974; Osanai et al., 1991; Shimura et al., 1992; Komatsu et al, 1994, and references therein). A Rb-Sr age of $23 \pm 1.2 \mathrm{Ma}$ obtained for a phlogopite-bearing spinel lherzolite is essentially identical to the oldest ages reported for the Hidaka metamorphic belt. This age may indicate the time of uplift for both the Horoman mantle sliver and the Hidaka metamorphic belt (Yoshikawa et al., 1993). 
The Horoman complex consists of a cyclically layered sequence of plagioclase lherzolite, lherzolite and harzburgite with subordinate amounts of dunite, gabbro and pyroxenite (Figure 2). The massif has been divided into two main zones (Niida, 1974; 1984):

1) The Lower Zone, approximately $2 \mathrm{~km}$ thick, consists of cyclic layers of plagioclase lherzolite to lherzolite to harzburgite, with some dunites; the cycle repeats every 100 to $500 \mathrm{~m}$. The abundance of mafic layers is sparse, with the exception of thin bands in the plagioclase lherzolite.

2) The Upper Zone, approximately $1 \mathrm{~km}$ thick, is characterized by a finescale layering (centimeter scale) of plagioclase therzolite and harzburgite as the dominant rock types, with subordinate dunite.

In the Upper Zone, plagioclase lherzolite and mafic layers are more abundant than in the Lower Zone (Takazawa, 1996; Takazawa et al., 1999a). Moreover, the equilibration temperature, calculated using the composition of orthopyroxene porphyroclast cores, increases from the Lower Zone to the Upper Zone by approximately $100^{\circ} \mathrm{C}(\mathrm{Ozawa}$ and Takahashi, 1995; Takazawa et al., 1996). The association of high equilibration temperature, and the high proportion of mafic layers and plagioclase lherzolite in the Upper Zone, suggests a genetic link between these rock types (Ozawa and Takahashi, 1995).

The compositional layering and the presence of fine grain size mineral aggregates (seams) define the foliation planes in the Horoman peridotite. The megascopic structures are characterized by a monoclinal layered structure in the northern part, a synclinal structure in the central part and a domal structure in the southern part of the massif (Niida, 1984). The border between the Upper and Lower Zones is continuous, without evidence for a thrust or shear zone (Niida, 1974; Frey et al., 1991; Takazawa, 1996; Takazawa et al., 1999a). In the same way, the boundary between the compositional layers is sharp on mesoscopic scale, but transitional over a few centimeters on a microscopic scale.

Petrographic studies show that the plagioclase in the plagioclase-lherzolite usually occurs in seams associated with spinel, pyroxenes, olivine and Ti-pargasite. The seams share a similar mineralogical association with the mafic layers (Niida, 1984; Takahashi and Arai, 1989; Takazawa et al., 1999a; 1999b). Moreover, in the plagioclase lherzolite, the seams and orthopyroxene porphyroclasts contain two-pyroxene, $\mathrm{Cr}$-spinel symplectites. 
Takahashi and Arai (1989) and Ozawa and Takahashi (1995) interpreted the symplectites as the breakdown product of gamet formed by subsolidus reaction during decompression. This is also consistent with the garnet pyroxenite composition of the Type I mafic layers (Takazawa et al., 1999a). Thus, the mafic layers and the seams from the plagioclase lherzolite seem to have a common mineralogy suggesting a genetic link between them.

Based on petrography and mineralogy, Takahashi (1991) divided the Horoman complex into three genetically different peridotitic suites:

1) The Main Harzburgite-Lherzolite suite, consisting of a harzburgite, spinel lherzolite and plagioclase lherzolite layered complex, with transitional boundaries, representing residues after various degree of magma extraction.

2) The Banded Dunite-Harzburgite suite, consisting of dunites and harzburgites with olivine orthopyroxenites, with sharp layer boundaries, representing cumulates from a Mg-rich magma.

3) The Spinel-rich Dunite-Wehrlite suite, consisting of dunites with large oblate chromian spinels representing cumulates from magma segregated from the surrounding Main Harzburgite-Lherzolite suite.

The earlier division of the complex given by Niida $(1974 ; 1984)$ considers only the Main Harzburgite-Lherzolite suite of Takahashi (1991), and this is is the main focus of our work.

In the Horoman peridotite, there are five different petrographic types of mafic layers (Niida, 1984; Shiotani and Niida, 1997; Takazawa et al., 1999a), of which two are dominant (Takazawa et al, 1999a):

Type I : plagioclase $+\mathrm{Ti}$ augite + olivine + orthopyroxene $+\mathrm{Ti}$ pargasite (or kaersutite) + green spinel + titaniferous magnetite + ilmenite + sulfide

Type II : plagioclase $+\mathrm{Cr}$ diopside + olivine + orthopyroxene + pargasite + spinel + magnetite + sulfide

The mafic layers vary from a few centimeters to several meters in thickness, are usually oriented parallel to the foliation plane of the peridotite and typically are in sharp contact with the ultramafic host (Niida, 1984, Takazawa et al., 1999a). Sometimes in the plagioclase-lherzolite, it is possible to observe that the large seams of mafic compositions 
grade into Type I mafic layers (Niida, 1984), suggesting a genetic relationship between the seams and the Type I layers.

The primary mineral assemblages in the mafic layers indicate multiple episodes of melt injection over a wide range of pressure, from the garnet stability field (Type I) to the plagioclase stability field (Type II) (Takazawa et al., 1999a). The sequence of the mafic injection is controversial. Takazawa, (1996) initially considered a simple sequence for intrusion of the mafic layers, starting first in the garnet and ending in the plagioclase stability field. Field observations support this sequence, with Type I layers being highly discontinuous, indicating that they have experienced more deformation than the Type II layers, which are traceable for more than a kilometer. Lately, Takazawa et al. (1999a), proposed a second possible sequence of intrusion based on $\mathrm{Nd}$ model ages. They suggest that Type II layers intrude at low pressure, early in the evolution of the Horoman complex and Type I layers intrude later at high pressure, during the subduction of the Horoman complex.

\subsubsection{Sampling the Bozu section}

We chose the Bozu section for our study, as it is a representative $140 \mathrm{~m}$ section from the Lower Zone. This section is a continuously exposed lithologic sequence ranging from harzburgite to therzolite to plagioclase lherzolite, and it has been geochemically wellcharacterized, with integrated geochemical observations made on a scale of $\mu \mathrm{ms}$ to tens of meters (Takazawa et al., 1992; 1996; Takazawa, 1996; Takazawa et al., 1999b) (Figure 3a). Based on this study of the Bozu section, Takazawa and co-workers concluded that the layered structure was produced by melting of an upwelling fertile mantle (plagioclase lherzolite) approximately $1 \mathrm{Ga}$ ago. In the lithosphere, the Horoman massif suffered metasomatism by a light-REE-rich melt/fluid, producing enrichment of incompatible elements in harzburgite, lherzolite and in a special type of plagioclase-lherzolite that Takazawa et al, 1999b defined as E-type (Figure 3b). The E-Type plagioclase lherzolite is enriched in $\mathrm{MgO}, \mathrm{Mg}^{\#}$ and in the very incompatible trace elements (LREE), but is depleted in $\mathrm{TiO}_{2}, \mathrm{Al}_{2} \mathrm{O}_{3}, \mathrm{CaO}, \mathrm{Na}_{2} \mathrm{O}$ and $\mathrm{HREE}$ contents similar to that of the lherzolites. During uplift of the massif, the peridotite was transformed from the garnet to spinel to plagioclasefacies mineralogy by subsolidus reaction.

We selected two harzburgite, two lherzolites, four E-type plagioclase lherzolites and ten plagioclase lherzolites for Re-Os isotopic systematics. In addition, we analyzed two 
Type I mafic layers for Re-Os isotopes; one from the Lower Zone and one from the Upper Zone. With the exception of the plagioclase-lherzolites, where we analyzed all the samples available, the peridotite samples are all from the center of their respective layers, to avoid transitional areas.

\subsection{Analytical Techniques}

The 200 to 500 gram samples were sliced into several slabs using a diamond saw, and they were later polished using silicon carbide sand paper to remove contamination from the saw. The samples were washed with Millipore water in an ultrasonic bath and dried on a hotplate at $50^{\circ} \mathrm{C}$. Finally, the samples were wrapped in plastic and hammered to small chips, and the chips were powdered in an agate shatterbox (Takazawa et al., 1999b).

The analytical techniques for Re-Os isotopes were described in Ravizza and Turekian (1989) and Hauri and Hart (1993). Re and Os were determined on separate powder splits. For the analysis of Os, $1 \mathrm{~g}$ of sample powder was fused by the NiS fireassay technique. The sample powder was spiked with ${ }^{190} \mathrm{Os}$ and mixed with high purity boric acid, $\mathrm{Ni}$ and $\mathrm{S}$ powders. A 4:1 or 2:1 mixture of flux to sample, for peridotite and mafic layer respectively, were fused at $1050^{\circ} \mathrm{C}$ to $1150^{\circ} \mathrm{C}$. This step produced a NiS bead that scavenges Os from the melted rock. The bead is dissolved in $6 \mathrm{~N} \mathrm{HCl}$ and the solution is filtered. The filter is dissolved in an oxidizing $\mathrm{CrO}_{3}+\mathrm{H}_{2} \mathrm{SO}_{4}$ acid solution, from which the $\mathrm{OsO}_{4}$ is distilled and trapped in $\mathrm{HBr}$. The $\mathrm{HBr}$ solution is dried down to a 1-2 $\mu 1$ drop and diluted with $\mathrm{H}_{2} \mathrm{O}$ until a of $1 \mathrm{~N} \mathrm{HBr}$ slution is obtained. A single bead of Chelex 50 resin is added to the $\mathrm{HBr}$ solution to extract the Os. The Chelex bead is deposited in concentrated $\mathrm{HBr}$, liberating the $\mathrm{Os}$, and this is then loaded onto a Pt filament with $\mathrm{BaNO}_{3}$ as an activator. The Os concentrations and isotopic compositions were measured by negative thermal ionization mass spectrometry on NIMA-B (WHOI), with oxygenenhanced emission and single collector analog detection using an electron multiplier and a dynamic collection routine.

For Re analysis, $1 \mathrm{~g}$ of sample powder is spiked with ${ }^{185} \mathrm{Re}$ and digested in a mixture of $\mathrm{HF}-\mathrm{HNO}_{3}$. Re is extracted by a simple ion exchange technique using AG1X8 anion resin. The Re is absorbed onto the resin from $0.5 \mathrm{~N} \mathrm{HNO}_{3}$ and eluted in $4 \mathrm{~N} \mathrm{HNO}_{3}$. An identical second step is used to further purify the Re. The Re measurements were done 
on a Finnigan MAT Element ICP-MS (at WHOI) by rapid peak hopping using electrostatic scanning.

In-run precision is $2 \sigma<0.35 \%$ for ${ }^{187} \mathrm{Os} /{ }^{188} \mathrm{Os}, 2 \sigma<1 \%$ for Os concentration and $2 \sigma<2 \%$ for Re concentration. Analytical blanks ranged from 0.2 to 0.26 for ${ }^{187} \mathrm{Os} /{ }^{188} \mathrm{Os}$, 1.2 to $1.4 \mathrm{pg} \mathrm{g}^{-1}$ of flux for Os concentration, and 2 to $3 \mathrm{pg}$ total procedural blank for $\mathrm{Re}$ concentration. All samples have been corrected for blank contribution; The correction is insignificant for $\mathrm{Re}$ and Os contents or Os isotopic composition, with the exception of samples BZ-116 and BZ-125 which have an estimated $2 \sigma$ error of $\approx 25 \%$ for $\operatorname{Re}$ concentration due to the blank correction. Re and Os replicates on separated powder split differ by $<10 \%$ for Re, $<2 \%$ for Os concentration, and $<0.5 \%$ for ${ }^{187} \mathrm{Os} /{ }^{188} \mathrm{Os}$.

\subsection{Results}

Results for 20 ultramafic and mafic samples analyzed from the Horoman peridotite are listed in Table 1; whole rock major and trace elements compositions are reported by Takazawa et al. (1999a, 1999b). In the Bozu section, the ${ }^{187} \mathrm{Os} /{ }^{188} \mathrm{Os}$ ratios of the ultramafic rocks ranges from 0.1158 to 0.1283 , while the Re and Os concentrations vary from 7 to $350 \mathrm{ppt}$ and from 2.9 to $5.2 \mathrm{ppb}$ respectively. Thus, while the Re content varies by a factor of 50 , the Os concentration varies by about a factor 2 .

There are two important observations that we can make directly from this data set:

1) The ${ }^{187} \mathrm{Os} /{ }^{188} \mathrm{Os}$ ratios obtained over a $140 \mathrm{~m}$ section of peridotite is as large as the range in Os isotopic composition reported for a number of peridotite massifs such as Beni Boussera, Baldisero, Lanzo, Lherz and Ronda (Roy-Barman et al., 1996; Reisberg et al., 1991; Reisberg and Lorand 1995), (Figure 4a).

2) The lowest and highest Os isotopic ratios found for the Horoman suite correspond to two samples separated by a distance of only $5 \mathrm{~m}$. The samples are an E-type and a N-type (normal) plagioclase lherzolite respectively (Figure 4b).

The ${ }^{187} \mathrm{Os} /{ }^{188} \mathrm{Os}$ ratios correlate negatively with the extent of melt depletion calculated for each rock type (Figure 5, also compare $3 \mathrm{a}$ and $4 \mathrm{~b}$ ). There is a gradual decrease in the Os isotopic composition from plagioclase lherzolites to lherzolites to harzburgites, suggesting a progressive time-integrated depletion in Re/Os. 
${ }^{187} \mathrm{Os} /{ }^{188} \mathrm{Os}$ ratios and $\mathrm{Re}$ contents define a negative correlation with $\mathrm{MgO}$ concentrations; however, the Os content does not correlate with either ${ }^{187} \mathrm{Os} /{ }^{188} \mathrm{Os}$ ratios, or $\mathrm{Re}$ or $\mathrm{MgO}$ concentrations (Figure 6). The negative correlation between $\mathrm{Re}$ and $\mathrm{MgO}$ contents suggests that Re behaves as a moderately incompatible element during melting. This is supported by the positive correlation between $\mathrm{Re}$ and $\mathrm{Al}_{2} \mathrm{O}_{3}, \mathrm{Sc}$ and $\mathrm{Yb}$ contents, and between $\mathrm{Re}$ and the modal proportion of clinopyroxene (Figure 7). Moreover, the well-defined correlation (one to one) with the zero intercept between $\mathrm{Re}$ and $\mathrm{Yb}$ suggest that both elements have similar bulk partition coefficients (in agreement with the conclusion of Hauri and Hart, 1997). On the other hand, the small variation in Os concentration (factor of $\approx 2$ ) indicates that Os behaves as a highly compatible element during mantle melting (Morgan, 1986; Hart and Ravizza, 1996).

The ${ }^{187} \mathrm{Os} /{ }^{188} \mathrm{Os}$ ratios for Horoman peridotites define a positive correlation with Re content (Figure 7) and ${ }^{187} \mathrm{Re} /{ }^{188} \mathrm{Os}$ ratios (Figure 8). The ${ }^{187} \mathrm{Os} /{ }^{188} \mathrm{Os}$ ratios for the ultramafic samples are lower than the Os isotopic composition estimated for the Primitive Upper Mantle (PUM $=0.1290 \pm 0.0009$; Meisel et al., 1996). Moreover, most of the samples have ${ }^{187} \mathrm{Re} /{ }^{188} \mathrm{Os}$ ratios below PUM (PUM= 0.4 - 0.428; McDonough and Sun, 1995; Meisel et al., 1996; Morgan, 1986, Luck and Allègre, 1983). However, five NType plagioclase lherzolite plot to the right of the geochron and four of the five samples have higher ${ }^{187} \mathrm{Re} /{ }^{188} \mathrm{Os}$ ratios than the estimates for PUM.

Two mafic layers were also analyzed for Re-Os isotopes (Table 1). In both cases they correspond to the Type I mafic layers (garnet pyroxenites) defined by Takazawa et al., (1999a). The Os isotopic ratios of these samples, ranging from 0.788 to 2.001 , are much higher than the nearly chondritic ratios of the ultramafic rocks. The ${ }^{187} \mathrm{Re} /{ }^{188} \mathrm{Os}$ ratios range from 34.8 to 86.36 , a variation that is closely related to the Os isotopic range. In the mafic layers, the Re contents (3.5 - $0.23 \mathrm{ppb})$ are higher than the Os concentrations (0.245 0.035), and the range in Re content is a factor of 2 higher than that for Os.

Table 1 show model ages for the Horoman samples calculated in two different ways. One method $\left(\mathrm{T}_{\mathrm{MA}}\right)$, as defined by Luck and Allègre (1984), extrapolates the ${ }^{187} \mathrm{Re} /{ }^{188} \mathrm{Os}$ back in time until the Os isotopic composition of the sample equals that for a model of the isotopic evolution of the mantle. This model is sensitive to problems of Re modification by metasomatism or melt addition. These processes may change the Re but are unlikely to change the Os of the peridotites. The high concentration of Os in peridotite 
compared to basalts or fluids preclude any modification of Os contents, or even the isotopic composition, if the metasomatic process is relatively young. Thus, to avoid potential problems with open system Re behaviour, Walker et al. (1989), calculated "Re depletion model ages" $\left(\mathrm{T}_{\mathrm{RD}}\right)$. The calculations for this model are done in the same way as above, but assumes that the Re/Os ratios of the sample is equal to zero (Table 1 and Figure 9). Thus, this method gives minimum model ages for the Re depletion event. Two main observations can be made from the model ages of the Horoman samples:

1) Assuming a mantle source equal to PUM, $T_{M A}$ gave implausible ages for some of the ultramafic rocks indicating that the Re-Os systems has not remained closed since melting. This is especially the case for the N-Type plagioclase lherzolites, which have ${ }^{187} \mathrm{Re} /{ }^{188} \mathrm{Os}$ higher than PUM. In these cases, the model ages are in the future, indicating mainly the addition of $\operatorname{Re}$ to the peridotite. In contrast, the two mafic layers give reasonable model ages of 1.3 to $1.16 \mathrm{Ga}$, similar to the ages of $\approx 1 \mathrm{Ga}$ reported for the depletion event in the Horoman peridotites by Takazawa (1996) and Yoshikawa and Nakamura (1999) using Nd isotopes. However, Takazawa et al. (1999a), based on $\mathrm{Nd}$ isotopes, considered the age for the Type I mafic layers to be young ( $80 \mathrm{Ma}$ ), while the Type II layers are considered to be old $(\approx 0.8) \mathrm{Ga}$. These results are contrary to the field observations which show that the Type I layers are very discontinuous and have experienced more deformation than the Type II layers, some of which are traceable for more than a kilometer (Takazawa et al., 1999a). The field relationship and the Re-Os model ages are more consistent with the hypothesis that the Type I mafic layers are ancient, as previously proposed by Takazawa (1996). Moreover, if the Type I mafic layers are $80 \mathrm{Ma}$ old cumulates from a MORB source as proposed by Takazawa et al.( 1999a), it would require an unrealistically high ${ }^{187} \mathrm{Re} /{ }^{188} \mathrm{Os}$ ratio of $\approx 1400$ to produce the measured ${ }^{187} \mathrm{Os} /{ }^{188} \mathrm{Os} \approx 2$. This would also require subsequent major modification of the $\mathrm{Re} / \mathrm{Os}$ ratios, lowering it to the observed value of 86 .

2) The Re depletion model ages $\left(T_{R D}\right)$ for the sample with the lowest ${ }^{187} \mathrm{Os} /{ }^{188} \mathrm{Os}=0.1158$ yields a minimum age for the melt depletion event of $1.86 \mathrm{Ga}$ (Table 1 and Figure 9). This age constrains the age of melting to be much older than that previously estimated by Takazawa (1996) and Yoshikawa and Nakamura (1999).

The positive correlation defined by the Horoman peridotites in the isochron diagram $\left({ }^{187} \mathrm{Os} /{ }^{188} \mathrm{Os}\right.$ versus ${ }^{187} \mathrm{Re} /{ }^{188} \mathrm{Os}$ ) yields an apparent "age" of $1.04 \pm 0.4 \mathrm{Ga}$ (Figure 8 ). If the 
two mafic layers are included in the regression, the apparent "age" is $1.16 \pm 0.28 \mathrm{Ga}$ (Figure 10). These apparent "ages" again are very similar to ages reported for the ultramafic rocks based on Nd isotopes, by Takazawa (1996) and Yoshikawa and Nakamura (1999). Moreover, it suggests that Type I mafic layers are $\approx 1 \mathrm{Ga}$, much older than $80 \mathrm{Ma}$.

\subsection{Discussion}

\subsubsection{What controls the Re/Os systematics of the Horoman peridotite?}

The correlation between ${ }^{187} \mathrm{Os} /{ }^{188} \mathrm{Os}$ ratios and Re content (Figure 7) and the lack of correlation of Os isotopes with Os concentrations (Figure 6) suggest that the isotopic composition of the samples is mainly controlled by the variation in Re content. The large variation of $\operatorname{Re}$ (a factor of 50) compared to that of Os (factor of less than 2) indicates that the $\mathrm{Re} / \mathrm{Os}$ ratios in Horoman are mainly controlled by the variations in Re. Thus, the Os isotopic composition is mainly related to the variation of $\mathrm{Re} / \mathrm{Os}$ ratios ( $\operatorname{Re}$ content!) through ingrowth.

Given that the variation in Re content controls the Os isotopic composition, the next step is to determine what governs the variation in Re content. The negative correlation between $\mathrm{Re}$ and $\mathrm{MgO}$ and the positive correlation between $\mathrm{Re}$ and $\mathrm{Al}_{2} \mathrm{O}_{3}, \mathrm{Sc}$ and $\mathrm{Yb}$ contents, and the modal proportion of clinopyroxene, indicates that Re is mainly controlled by silicate phases. The variation in $\mathrm{Al}_{2} \mathrm{O}_{3}, \mathrm{Sc}$ and $\mathrm{Yb}$ contents, and the modal proportion of clinopyroxene in the ultramafic rocks indicates a change in the proportion of a basaltic component in the Horoman peridotites. Thus, the observed Re variation in Horoman was not produced by an exotic sulfide component as proposed by Burnham et al. (1998) in the Pyrenees, but by the variation in the proportion of a basaltic component between the different rock types. In contrast to the suggestion of Burnham et al. (1998) that $\operatorname{Re}$ is controlled by sulfides, in the Horoman peridotite the correlation of Re with $\mathrm{Yb}$ contents defines a linear trend that tends toward the origin. This simple observation indicates that both elements had similar bulk partition coefficient (D) during melting (Figure 7). Similar D's (bulk partition coefficient) for $\mathrm{Yb}$ and $\mathrm{Re}$, assuming that the Re content is controlled by sulfides, will require an extraordinary set of coincidences. For example, the variation in the proportions of sulfides and silicate phases in the mantle residue have to be compensated by the change of $\mathrm{D}_{\min / \text { melt }}$ (partition coefficient between a mineral phase and the melt) for Re and $\mathrm{Yb}$ between melt-crystal and melt-sulfide to keep the similarity in D's during melting. 
Moreover, Burton et al. (1998), by analyzing mineral separates from spinel and garnet peridotites, confirmed that the Re budget is almost exclusively controlled by silicate phases, especially garnet when present. The work of Burton et al. (1998) and the correlation found between $\mathrm{Yb}$ and $\mathrm{Re}$ for the Horoman peridotites, is confirmed by the experimental data of Righter and Hauri (1998) which proves that Re is compatible in garnet during melting. Although garnet is not present in Horoman peridotite, in the plagioclase lherzolite, the seams and orthopyroxene porphyroclasts contain two-pyroxene, Cr-spinel symplectites. Takahashi and Arai (1989) and Ozawa and Takahashi (1995) interpreted the symplectites as the breakdown product of garnet formed by subsolidus reaction during decompression.

In summary, the Os isotope ratios in the Horoman massif are controlled mainly by the variation in Re content, and the Re concentration is governed by the variation of a silicate phase (mainly garnet), which from now on we will call the "basaltic component".

\subsubsection{What is the process (or processes) responsible for the variation in the basaltic component in the Horoman peridotite?}

There are two simple processes that can produce the observed variation in "basaltic component": melt removal (melting) or melt addition (refertilization) to the peridotites. We can make use of the Re-Os systematics to differenciate between these two process, and to evaluate the origin of the layered structure and the plagioclase lherzolite. There are two main hypotheses:

a) the layered structure is produced by melting of a fertile mantle represented by the N-Type plagioclase lherzolite (Takazawa et al., 1999b; Yoshikawa and Nakamura, 1999; Takahashi, 1992)

b) the layered structure results from a combination of melting and melt accumulation, where the N-Type plagioclase therzolite is the zone of melt accumulation (Obata and Nagahara, 1987).

Clearly melting has played a fundamental role in defining the geochemical variation of the Horoman peridotites (Takazawa et al, 1999b; Yoshikawa and Nakamura, 1999 and references therein). Thus, the decrease in Re and Os isotopic composition on going from the N-Type plagioclase therzolite to the harzburgite can, in principle, be explained by progressive extraction of a basaltic component. This hypothesis can explain the correlation between $\mathrm{Re}$, Os isotopic composition, $\mathrm{MgO}$, modal clinopyroxene and $\mathrm{Al}_{2} \mathrm{O}_{3}, \mathrm{Sc}$ and $\mathrm{Yb}$ 
contents. However, the melt removal hypothesis has difficulty explaining the following observations:

1) The high $\mathrm{Re} / \mathrm{Os}$ ratios observed in five $\mathrm{N}$-Type plagioclase lherzolites plotting to the right of the geochron (Figure 8). Re/Os ratios higher than PUM and Chondrites Re/Os are difficult to explain by melt depletion processes. Although the value for the PUM Re/Os can be questioned, all the work done up to now has concluded that the $\mathrm{Re} / \mathrm{Os}$ ratios and Os isotopic composition for PUM is chondritic (McDonough and Sun, 1995, Meisel et al., 1996 and references therein). Moreover, new platinum group element (PGE) data for the Horoman peridotite, especially the supra-chondritic $\mathrm{Pd} / \mathrm{Ir}$ ratios, do not support the melting hypothesis (Rehkämper et al, 1997).

2) the small scale layering of the peridotitic massif. The samples with the highest and the lowest Os isotopic composition are only $5 \mathrm{~m}$ apart (Figure $4 \mathrm{~b}$ ). This range in Os isotopic composition observed in the Horoman peridotites overlaps with the reported range in Os isotopes for a compilation of peridotite massifs (Figure 4a). Although it can be argued that until now there is not a good understanding of the scale of melt extraction, to explain a variation in depletion of basaltic component from $8 \%$ to $19 \%$ over a $5 \mathrm{~m}$ distance seems excessive (Figure $3 a$ and $4 b$ ).

These two obstacles for the simple melt removal can be easily explained by the refertilization (melt addition) model. The addition of a basaltic component to a peridotite can explain the high $\mathrm{Re} / \mathrm{Os}$ ratios in the five plagioclase lherzolites, plotting to the right of the geochron, and can also explain the variation in Os isotopic composition over very short distances. Moreover, such refertilization processes would account for the correlation between $\mathrm{Re}$, Os isotopic composition, $\mathrm{MgO}$, modal clinopyroxene and $\mathrm{Al}_{2} \mathrm{O}_{3}, \mathrm{Sc}$ and $\mathrm{Yb}$ contents.

In the Horoman peridotite the linear variation of $\mathrm{Na}_{2} \mathrm{O}$ as a function of $\mathrm{MgO}$ and the high content of HREE in the N-Type plagioclase lherzolites (compared to melting models) suggest that melting did not take place in the spinel stability field (Takazawa et al., 1999b; Yoshikawa and Nakamura, 1999). To model the $\mathrm{Na}_{2} \mathrm{O}$ and HREE contents, Takazawa et al., (1999b) considered melting in the garnet stability field. Because the variation of HREE in the Horoman rocks requires a bulk $\mathrm{D}<1$, consideration of melting in the garnet field required a very small amount of garnet in the initial fertile peridotite (Takazawa et al., 1999b). However, no model has been presented to explain the variation of all the major 
elements. In the Horoman massif, the linear variation in major elements as a function of $\mathrm{MgO}$ and the high HREE content in the most fertile plagioclase lherzolites can also be explained by refertilization process, as we show below in point 2.5.3.

The main reason that previous studies have rejected the hypothesis of refertilization in peridotitic massifs is that peridotites are not enriched in incompatible trace elements relative to estimates for primitive mantle. There is no physical reason why the addition of the "basaltic component" should stop at a level just necessary to compensate for the initial depletion (Burnham et al., 1998, Takazawa et al., 1999b). This is an important point, and the answer can give important clues regarding melting processes, and on the type of "basaltic component" that produces the refertilization. To answer this question, we make two simple observations: First, previous works such as Johnson et al. (1990), have shown that melting of ocean ridge mantle approaches a fractional melting process, where the melt readily separates from the source, and accumulates prior to eruption. If this is the case, after 20 to $25 \%$ of melting (common estimates for harzburgites-lherzolites) the level of depletion would have stripped most of the incompatible trace elements from the residual mantle, especially the most incompatible elements. Second, there is no reason why the refertilization has to be identified with a basaltic melt phase. The "basaltic component" could be in the form of cumulates derived from basalt that passes through the lithosphere, cools and undergoes fractional crystallization. Thus, our "basaltic component" can be a mafic cumulate. The association between perdotites and mafic cumulates is common in peridotite massifs. Peridotitic massifs such as Horoman contain mafic layers that have been classified as mafic cumulates (Takazawa et al., 1999a). Clearly, to enrich $\mathrm{a} \approx 20 \%$ depleted peridotite in incompatible trace elements beyond the levels in primitive mantle will require such a large addition of a mafic cumulate ( $>20 \%$ ) that the mixture will no longer be a peridotite. In reality, certain elements that are moderately incompatible during melting of the peridotite and highly compatible in the crystallizing minerals forming the cumulates from the percolating basalts, can be enriched beyond the primitive mantle values during the refertilization. For elements that are highly incompatible during melting, their concentration in the depleted peridotite will be so low that it will be impossible to refertilize to values above primitive mantle. In contrast, elements that are moderately incompatible during melting can reach concentrations above the values for primitive mantle by the addition of reasonable amount of mafic cumulates. However, only some elements are moderately incompatible during melting and compatible in the crystallizing phases forming the 
cumulates. For example, let us assume that the peridotite melts in the spinel stability field, and that the percolating basalt forms cumulate of plagioclase or garnet; therefore $\mathrm{Sr}, \mathrm{HREE}$ and $\mathrm{Re}$ will be moderately incompatible during melting and strongly compatible ( $\mathrm{Sr}$ in plagioclase and HREE and Re in garnet) in the cumulate respectively. Thus, these elements can provide some clues regarding the refertilization process.

Several observations indicate that mixing between depleted peridotites, such as the E-Type plagioclase lherzolite, and mafic layers (Type I) provides a mechanism for the formation of the N-Type plagioclase lherzolites in the Bozu section.

1) The mineralogy of the seams in the plagioclase lherzolites are similar to that of the Type I mafic layers. The present mineralogy of the seams and mafic layers do not represent primary igneous phases, but is a mineral association produced by subsolidus reaction at lower pressure (Takazawa et al., 1999a). The primary mineralogy of the mafic layers can be calculated based on their major and trace element compositions. Thus, Takazawa et al., (1999a) determined that Type I mafic layers were garnet-pyroxenites. The presence of garnet in the mafic layers is consistent with the presence of othopyroxeneclinopyroxene-spinel symplectites in the seams, produced by decompression of garnet during subsolidus reaction (Takahashi and Arai, 1989). Moreover, garnet is the main phase that controls the Re content of the rock (Righter and Hauri, 1998; Burton et al, 1998), suggesting that the addition of garnet-pyroxenite to a depleted peridotite is responsible for the high $\mathrm{Re} / \mathrm{Os}$ ratios in the plagioclase lherzolite.

2) The high Re/Os ratios of the Type 1 mafic layers support this hypothesis, explaining the N-Type plagioclase lherzolite plotting to the right of the geochron by addition of garnet pyroxenite to a depleted peridotite.

3) The colinearity of the Type I mafic layers and the ultramafic rocks in a Re-Os isochron diagram suggest that these rocks are genetically related. The Re-Os isotopes of these rocks define an age of $\approx 1.16 \pm 0.28 \mathrm{Ga}$., similar to the reported age based on Nd isotopes (Takazawa 1996; Yoshikawa and Nakamura, 1999); this also supports the hypothesis that the mafic layers and the peridotites are genetically linked (Figure 10)

4) The field observation that Type I mafic layers are dismembered in the peridotite, passing transitionally from mafic layers to form seams in the plagioclase lherzolite (Niida, 1984), supports the hypothesis of refertilization. 
All of these observations endorse the Type I mafic layers as a suitable mafic end member for the mixing hypothesis. The field relationships between the mafic layers and the plagioclase lherzolite are especially supportive of this hypothesis.

\subsubsection{Can the mixing hypothesis explain the major and trace element contents of the fertile plagioclase lherzolite?}

The question now is can the hypothesis of mixing between Type I mafic layers and E-Type plagioclase lherzolite explain the major and trace element contents of the $\mathrm{N}$-type plagioclase lherzolite? To answer this question, we will model the N-Type plagioclase lherzolite as a mixture between E-Type plagioclase lherzolite and Type I mafic layers. It is a very difficult task to define the composition of the mixing components. Our simple approach is to use the mean composition of both the E-Type plagioclase lherzolite and the Type I mafic layers analyzed by Takazawa et al, (1999a and b). Moreover, by averaging the measured compositions we avoid the problem of dealing with any internal chemical differentiation which has affected the Type I layers (Takazawa et al., 1999a). Because the most depleted samples have undergone strong metasomatism (Takazawa et al., 1992), it is difficult to define a pristine depleted peridotite end-member (Figure 11). Therefore, we will avoid incompatible elements affected by metasomatism and model only the major elements, and the trace elements from $\mathrm{Gd}$ to $\mathrm{Lu}$, including $\mathrm{Cr}$ and $\mathrm{Sc}$. Note that the major elements $\mathrm{K}$ and $\mathrm{P}$ have been affected by metasomatism.

First, the dataare normalized following the scheme of Allègre et al, (1995) so that each element is given a comparable weight. Each parameter used is normalized to its standard deviation, multiplied by the concentration range and divided by the mean concentration and the analytical error. Allègre et al. (1995), argued that the elements that have larger ranges in concentration will carry more weight in the regression. Clearly, the elements that have a larger concentration range will be better indicators of the processes responsible for the geochemical variation. To model the mixing process, we consider the simple model presented by Cantagrel et al. (1984); they express the mixing equation

$$
\begin{aligned}
& \mathrm{Ca}^{*}(1-\mathrm{Xb})+\mathrm{Cb}^{*} \mathrm{Xb}=\mathrm{Cm}, \text { as } \\
& (\mathrm{Cb}-\mathrm{Ca}) * \mathrm{Xb}=(\mathrm{Cm}-\mathrm{Ca})
\end{aligned}
$$

where $\mathrm{Ca}, \mathrm{Cb}$ and $\mathrm{Cm}$ are the concentrations of an element in the depleted peridotite, the mafic layer, and the mixture (fertile peridotite) respectively; and $\mathrm{Xb}$ is the proportion of 
mafic layer in the mixture. We have defined the composition of the depleted lherzolite, the mafic layers and the mixture (fertile peridotite), so we can plot $(\mathrm{Cm}-\mathrm{Ca})$ as a function of $(\mathrm{Cb}-\mathrm{Ca})$, where each point represents one element. If the fertile peridotite is produced by mixing between a depleted peridotite and a mafic layer, the points in the figure will define a line passing through the origin with a slope $(\mathrm{Xb})$. The slope represents the proportion of the mafic component in the mixture (Figure 12). Thus, we apply a simple linear regression and obtained the proportion of the mafic component in the mixture, for each N-Type plagioclase lherzolite. For the uncertainty in the slope (proportion of mafic layers), we propagated the analytical errors reported by Takazawa et al, (1999a and b) and the error in the linear regression.

Figure 13 show the calculated values for all the elements normalized to their measured values for each of the $10 \mathrm{~N}$-Type plagioclase lherzolites. Surprisingly, the mixing model reproduces the measured major and trace element composition for the fertile plagioclase lherzolite quite well simply by using the same two end member component and only changing the proportion of the mafic component in the mixture. As we previously mentioned, $\mathrm{K}$ and $\mathrm{P}$ are the two elements that are not well reproduced by this model. We believe that the main reason for this is the $\mathrm{K}$ and $\mathrm{P}$ contents chosen for the depleted peridotite end member are too high, as result of metasomatism (Figure 11).

\subsubsection{The age of the melting and mixing events}

The ages of the melting and mixing events are not well defined. Up to now the age of the depletion event was considered to be $\approx 1 \mathrm{Ga}$, based on $\mathrm{Nd}$ isotopes (Takazawa 1996; Yoshikawa and Nakamura, 1999). In contrast, Re-Os depletion model ages indicates that the minimum age for the depletion event has to be older than $1.8 \mathrm{Ga}$ (Figure 9, Table 1). The ultramafic and mafic rocks from the Horoman massif define an apparent age of $1.16 \pm 0.28 \mathrm{Ga}$ in the Re-Os isochron diagram (Figure 10), similar to the age of $\approx 1 \mathrm{Ga}$ based on Nd isotopes reported by Takazawa (1996) and Yoshikawa and Nakamura, (1999). Moreover, the $\mathrm{Rb}-\mathrm{Sr}$ isotope systematics on whole rocks reported by Yoshikawa and Nakamura, (1999) also define an apparent age of $\approx 1 \mathrm{Ga}$. Thus, the consistency of the $\approx 1 \mathrm{Ga}$ age defined by the three isotopic systems suggests that this age has a geologic meaning. The colinearity between the mafic layers and the peridotites in the Re-Os isochron diagram and the $\approx 1.1-1.3 \mathrm{Ga}$ Re-Os model ages for the mafic layers suggest that the mafic layers are genetically related to the peridotite through a refertilization process $\approx 1$ 
Ga ago. Another interpretation is that the melt depletion and refertilization are two parts of the same process as envisioned by Obata and Nagahara (1987). These authors considered melting and melt segregation of an homogeneous mantle, where the depleted rocks represent residues of melting and the plagioclase lherzolite represents the region of melt accumulation. If this is the case, $1 \mathrm{Ga}$ is the time of depletion and refertilization, and the $\mathrm{Re}$ depletion model age older than $1.8 \mathrm{Ga}$ indicates that the Horoman peridotite was a depleted peridotite previous to the depletion and refertilization event at $1 \mathrm{Ga}$.

In synthesis, the Re-Os isotope systematics indicate that the age of melting event in Horoman peridotites is $\geq 1.8 \mathrm{Ga}$ (Re depletion model age), much older than the ages $\approx 1$ Ga previously estimated based on Nd isotopes (Takazawa et al., 1999b; Yoshikawa and Nakamura, 1999). Re-Os isotope systematics, major and trace elements contents, and field and petrographic information are consistent with the hypothesis that the N-Type plagioclase lherzolite are produced by refertilization of the depleted peridotite by the addition of mafic cumulates (Type I) at $\approx 1 \mathrm{Ga}$. Refertilization of a depleted peridotite seems a more suitable process than melting to explain the variation in major elements and Os isotopes at the scale of a few meters. We propose that the refertilization process has played an important role in the formation of the layering, especially in the Horoman massif where the plagioclase Iherzolite forms $60 \%$ of the total outcrop (Takazawa et al., 1999a).

\subsubsection{Is Horoman an unusual place or does the refertilization process play a role in other peridotite massifs?}

Several peridotite massifs have been studied with Re-Os sytematics: Ronda, the Pyrenees (Lherz), Beni Bousera, Lanzo (Reisberg et al, 1991; Reisberg and Lorenz, 1995, Roy-Barman et al, 1996 Burnham et al. 1998, among others). However, with the exception of Ronda, Re-Os isotopic data combining both peridotite and the associated mafic rocks are sparse. Although the data are meager, the Re-Os systematics seem to indicate that a refertilization processes could have played an important role in these orogenic therzolite massifs. Figure 14 shows whole rock Re-Os isochron diagrams for several peridotite massifs. In all of these cases, the most fertile samples have high Re/Os ratios, plotting to the right of the geochron. Moreover, the mafic layers are co-linear with the ultramafic rocks defining ages that are similar to the ages determined by $\mathrm{Nd}$ isotopes. The fact that both the Re-Os and Sm-Nd isotope systematics give similar ages suggests that the linear array on the isochron diagram is not only an indication of mixing but may also represent the

age of refertilizaltion. In Ronda, Reisberg et al, (1991), analyzed both garnet-rich and 
spinel-rich mineral bands; when plotted on the isochron diagram, only the garnet-rich bands are colinear with the ultramafic rocks. These garnet-rich seams in Ronda have been interpreted to be the product of tectonic disaggregation of mafic layers in an isotopically depleted peridotite (Reisberg et al, 1989). These observations from Ronda mimic the observations made in Horoman. Two different processes have been invoked to explain the colinearity of the mafic layers and the ultramafic rocks in the Re-Os isochron diagram for the Ronda massif (Reisberg et al, 1991, Roy-Barman et al., 1996):

1) The marble cake model of Allègre and Turcotte (1986), where the mafic layers are remnants of subducted oceanic crust and the colinearity has no age significance.

2) The mafic layers represent both, cumulates formed during an ancient melting event and residues of earlier mafic layers that reequilibrate during that ancient melting event (Reisberg et al., 1991).

We discard the first model because a systematic study of the mafic layers in Ronda indicates that they are cumulates (Garrido and Bodinier, 1999). Moreover, the agreement between the Re-Os and Sm-Nd ages supports the hypothesis that the ages are significant. The second model is similar to our model for refertilization with the difference that Reisberg et al (1991) considered the isochron to record a melt depletion event, even though they proposed that the most fertile garnet peridotite was produced by refertilization through tectonic disaggregation of mafic layers. These authors also discarded mixing as an explanation because some of the mafic layers where not co-linear with the ultramafic rocks. Not all mafic layers are formed at the same time and therefore not all of them need be responsible for the refertilization process. In Ronda, the best examples of refertilization are the garnet-rich seams produced by disaggregation of garnet-rich mafic layers, which are colinear with the ultramafic rocks (Figure 14). Although Beni Boussera and Lanzo are less convincing examples, due to the few samples analyzed, they show the same tendency as that observed in Ronda, with the mafic layers being colinear with the ultramafic rocks. In the Pyrenees, only ultramafic rocks have been analyzed for both Re-Os isotopic systematics. There are Os isotopic data for mafic layers, there are no reported Re contents. We predict that the Pyrenees will show the same tendencies as Horoman, Ronda and the other peridotite massifs.

If the hypothesis of refertilization is confirmed, it will have important implications for understanding how the continental crust forms and grows. Any hypothesis of how the 
crust grows will be different whether we consider that the ages represent melting events of asthenospheric material, or refertilization events of an old depleted lithosphere. Both processes will have consistency between the ages observed in the crustal material and those obtained from the peridotitic massifs. Thus, the ages could indicate either stabilization of both young crust and lithospheric mantle or the refertilization of a depleted lithospheric mantle already stable. For example, Griffin et al. (1998), concluded that subcontinental mantle lithosphere (SCML) becomes progressively less depleted from Archean through Proterozoic to Phanerozoic times. The broad correlation between the SCML composition and the crustal age implies quasi-contemporaneous formation of the crust and its lithospheric mantle. Moreover, this broad correlation would suggest that the extent of melting progressively decreased from the Archean to the Phanerozoic. In contrast to Griffin et al., (1998) hypothesis, we speculate that the correlation between depletion of the SCML and the mantle ages does not indicate formation and stabilization of the continental crust and its lithosphere, but indicates a process of refertilization of the SCML and a resetting of an already stable continental area. Thus, the correlation between mantle lithosphere and crustal ages and extent of depletion of the lithosphere may not have any implicit indication of a correlation between the extent of melting and time.

\subsection{Conclusions}

$\mathrm{Re}-\mathrm{Os}$ isotope systematics in Horoman peridotites indicate that the Os isotopes are mainly controlled by variations in Re content, while Re contents are controlled by the variation of a "basaltic component" in the ultramafic rocks.

Re-Os isotopes, major and trace elements contents, and field and petrographic information are consistent with the hypothesis that the Horoman N-Type plagioclase lherzolites are produced by refertilization of a depleted peridotite, by the addition of a garnet-rich mafic cumulate.

Refertilization of depleted peridotite seems a more suitable process than melting to explain large variations in major elements and Os isotopes over very short distances. For example, the total range in Os isotopic composition occurs between two samples only $5 \mathrm{~m}$ apart. Therefore, we propose that refertilization processes have played an important role in the formation of the layering, especially in the Horoman massif, where the fertile plagioclase lherzolite forms $60 \%$ of the total outcrop. 
Re depletion model ages of $\approx 1.8 \mathrm{Ga}$ suggests that the age of melting is much older than $\approx 1 \mathrm{Ga}$ previously estimated based on $\mathrm{Nd}$ isotopes (Takazawa et al., 1999b; Yoshikawa and Nakamura, 1999). On a Re-Os isochrone diagram the Type I mafic layers and the peridotitic samples are colinear and define an apparent age of $\approx 1 \mathrm{Ga}$, similar to the $\mathrm{Nd}$ ages; this suggests that the linear trend in the isochron diagram is not only an indication of mixing but has an age significance, and may represent the age of refertilization.

If the refertilization hypothesis is confirmed, it will have important implications for the understanding of how the continental lithosphere forms and grows. 


\subsection{References}

Allègre C. J. and Turcotte D. L., Implications of a two-component marble-cake mantle. Nature 323: 123-127, 1986.

Allègre C. J., Schiano P. and Lewin E., Differences between oceanic basalts by multytrace element ratio topology. Earth Planet. Sc. Lett. 129: 1-12, 1995.

Anders E. and Grevesse N., Abundances of the elements: meteoritic and solar. Geochim. Cosmochim. Acta 53: 197-214.

Arai S. and Takahashi N., Formation and compositional variation of phlogopites in Horoman peridotite complex, Hokkaido, Japan: Implications for the origin and fractionation of metasomatic fluids in the upper mantle. Contrib. Mineral. Petrol. 101: $165-175,1989$.

Burnham O. M., Rogers N. W., Pearson D. G., van Calsteren P. W. and Hawkesworth C. J., The petrogenesis of the eastern Pyrenean peridotites: An integrated study of their whole-rock geochemistry and Re-Os isotope composition. Geochim Cosmochim. Acta, 62: 2293-2310, 1998.

1998.

Burton K. W., Schiano P., Birck J. L. and Allègre C. J., The behaviour of Re and Os in mantle minerals with implications for mantle melting. EOS, Transactions, AGU, S373, 1998.

Carlson R. W. and Irving A. J., Depletion and enrichment history of subcontinental lithospheric mantle: $\mathrm{An} \mathrm{Os}, \mathrm{Sr}, \mathrm{Nd}$ and $\mathrm{Pb}$ isotopic study of ultramafic xenoliths from the northwestern Wyoming craton. Earth Planet. Sc. Lett. 126: 457-472, 1994.

Cantagrel J. M., Didier J. and Gourgaud A., Magma mixing: Origin of intermediate rocks and enclaves in volcanism to plutonism. Phys. Earth Planet. Int. 35: 63-76, 1984.

Frey F. A., Shimizu N., Leinbach A., Obata M. and Takazawa E., Compositional variations within the lower layered zone of the Horoman peridotite, Hokkaido, Japan: Constraints on models for melt-solid segregation. J Petrology Special Lherzolite Issue 211227, 1991.

Garrido C. J. and Bodinier J. L., Diversity of mafic rocks in the Ronda peridotite: evidence for pervasive melt/rock reaction during extension of subcontinental lithospheric mantle. J . Petrology 40 (5): 729-754, 1999.

Griffin W. L., O'Reilly S. Y. and Ryan C. G., The composition of the subcontinental lithospheric mantle: garnet-based estimates. Min. Magazine Goldschmidt Conference, Toulouse, 62A part 1: 541-542, 1998 .

Handler M. R., Bennett V. C. and Tezer M. E., The persistence of off-cratonic lithospheric mantle: Os isotopic systematics of variably metasomatised southeast Australian xenoliths. Earth Planet. Sc. Lett. 151: 61-75, 1997. 
Hart S. R. and Ravizza G. E., Os partitioning between phases in lherzolite and basalts. In Earth Processes: Reading the isotopic code. Geophysical Monograph 95: 123-134, 1996.

Hauri E. H. and Hart S. R., Re-Os isotope systematics of HIMU and EMII oceanic island basalts from the south Pacific ocean. Earth Planet. Sc. Lett. 114: 353-371, 1993.

Hauri E. H. and Hart S. R., Rhenium abundances and systematics in oceanic basalts. Chem. Geology 139, (1-4), 185-205, 1997.

Johnson K. T., Dick H. J. And Shimizu N., Melting in the oceanic upper mantle: an ion microprobe study of diopsides in abyssal peridotites. J. Geophys. Res. 95: 2661-2678, 1990 .

Komatsu M. and Nochi M., Ultrabasic rocks in Hidaka metamorphic belt, Hokkaido, Japan. I. Mode of occurrence of the Horoman ultrabasic rocks. Earth Science 20: 99-108, 1966.

Komatsu M., Toyoshima T., Osanai Y. and Arai M., Prograde and anatectic reactions in the deep arc crust exposed in the Hidaka metamorphic belt, Hokkaido, Japan. Lithos, 33: $31-49,1994$.

Luck J. M. and Allègre C. J., ${ }^{187}{ }^{R e}-{ }^{187}$ Os investigation in sulfide from Cape Smith komatiite. Earth Planet. Sc. Lett. 68: 205-208, 1984.

Luck J. M. and Allègre C. J., Osmium isotopes in ophiolites. Earth Planet. Sc. Lett. 107: 406-415, 1991.

Luck J. M. and Allègre C. J., 187Re-187Os systematics in meteorites and cosmochemical consequences. Nature 302: 130-132, 1983.

Martin C. E., Osmium isotopic characteristics of mantle-derived rocks. Geochim Cosmochim. Acta, 55: 1421-1434, 1991.

McDonough W. F. and Sun S. - s., The composition of the Earth. Chem. Geol. 120: 223253,1995 .

Meisel T., Walker R. J. and Morgan J. W., The osmium isotopic composition of the Earth's primitive upper mantle. Nature, 383: 517-520, 1996.

Miyashita S., Reconstruction of the ophiolite succession in the western zone of the Hidaka metamorphic belt, Hokkaido. J. Geol. Soc. Japan 89: 69-86,1983.

Morgan J. W., Ultramafic xenoliths: Clues to Earth's late accretionary history. J. Geophys. Res. 91: 12375-12387, 1986.

Morishita T. and Kodera T., Finding of corundum-bearing boulder possibly derived from the Horoman peridotite complex, Hokkaido, northern Japan. J. Min. Petrol. and Econ. Geol. 93: 52-63, 1998.

Nagasaki H., A layered ultrabasic complex at Horoman, Hokkaido, Japan. J. Fac. Sc. Univ. Tokyo, 16:313-346, 1966. 
Niida K., Structure of the Horoman ultramafic massif of the Hidaka metamorphic belt in Hokkaido, Japan. J. Geol. Soc. Japan, 80: 31-44, 1974.

Niida K., Petrology of the horoman ultramafic rocks. J. Fac. Sc. Hokkaido Univ. Ser. IV 21: 61-81, 1984.

Obata M. and Nagahara N., Layering of apline-type peridotite and the segregation of partial melt in the upper mantle. J. Geophys. Res 92: 3467-3474, 1987.

Osawa K. and Takahashi N., P-T history of a mantle diapir: The horoman peridotite complex, Hokkaido, northern Japan. Contrib. Mineral. Petrol. 120: 223-248, 1995.

Osanai Y., Komatsu M. And Owada M., Metamorphism and granite genesis in the Hidaka metamorphic belt, Hokkaido, japan. J. Metam. Geol. 9: 111-124, 1991.

Ravizza G. and Turekian K. K., Applications of the 187Re-187Os system to black shale geochronology. Geochim Cosmochim. Acta, 53: 3257-3262, 1989.

Reisberg L., Zindler A. and Jagoutz E., Further $\mathrm{Sr}$ and $\mathrm{Nd}$ isotopic results from peridotites of the Ronda ultramafic complex. Earth Planet. Sc. Lett. 96: 161-180, 1989.

Reisberg L. C., Allègre C. J. and Luck J. M., The Re-Os systematics of the Ronda ultramafic complex of southern Spain. Earth Planet. Sc. Lett. 105: 196-213, 1991.

Reisberg L. and Lorand J. P., Longevity of sub-continental mantle lithosphere from osmium isotope systematics in orogenic peridotite massifs. Nature, 376: 159-162, 1995.

Rehkämper M., Halliday A. N. and Fitton J. G., Fractionation of Platinum-Group-Element abundances in the lithospheric mantle. Lunar and Planet. Inst. Contrib. 921 :171-172, 7th Goldschmidt Conference, Tucson, 1997.

Righter K. and Hauri E. H., Compatibility of rhenium in garnet during mantle melting and magma genesis. Science, 280: 1737-7141, 1998.

Roy Barman M., Luck J. M. and Allègre C. J., Os isotopes in orogenic lherzolite massifs and mantle heterogeneities. Chem. Geol. 130: 55-64, 1996.

Shimura T., Komatsu M. and Iriyama J. T., Genesis of the lower crustal garnetorthopyroxene tonalites (S-type) of the Hidaka metamorphic belt, northern Japan. Trans. Royal Soc. Edinburgh : Earth Sc. 83: 259-268, 1992.

Shiotani Y. and Niida K., Origin of the mafic layers in the Horoman peridotite complex. Mem. Geol. Soc. Japan, 47: 123-137, 1997.

Shirey S. B. and Walker R. J., The Re-Os isotope system in cosmochemistry and high temperature geochemistry. An. Rev. Earth Plan. Sc.. 1997,

Smoliar M. I., Walker R. J., Morgan J. W., Re-Os age of group IIA, IIIA, IVA and IVB iron meteorites. Science 271: 1099-1102, 1996. 
Takahashi N., Arai S. and Murota Y., Alkali metasomatism in peridotite complexes from the Hidaka belt, Hokkaido, northern Japan. J. Geol. Soc. Japan, 95: 311-329, 1989.

Takahashi N., Origin of three peridotite suites from Horoman peridotite complex, Hokkaido, Japan: Melting, melt segregation and solidification processes in the upper mantle. J. Min. Petrol. And Econ. Geol. 86: 199-215, 1991.

Takahashi N. Evidence for melt segregation towards fractures in the Horoman mantle peridotite complex. Nature, 359: 52-55, 1992.

Takahashi N. and Arai S., Textural and chemical features of chromian spinel-pyroxene symplectites in the Horoman peridotites, Hokkaido, Japan. Sc. Rep. Inst. Geosc. Univ. Tsukuba, Sect B, 10: 45-55, 1989.

Takazawa E., Frey F. A., Shimizu N., Obata M. and Bodinier J. L., Geochemical evidence for melt migration and reaction in the upper mantle. Nature 359: 55-58, $1992 \mathrm{a}$.

Takazawa E., Frey F. A., Shimizu N., Obata M. and Nakamura E., Geochemical characteristics of the Horoman layered ultramafic complex, Hokkaido, Japan: Evidence for fluid migration and reaction in the upper mantle. 29Th Int. Geol. Congr. Abst., Kyoto, p $174,1992 b$.

Takazawa E., Shimizu N. and Frey F. A., Compositional zoning in clinopyroxenes from the Horoman layered ultramafic complex, Japan. EOS, Transactions, AGU, F682, 1993.

Takazawa E., Shimizu N. and Frey F. A., Development and evolution of the lithospheric mantle: a case study from the Horoman peridotite, Japan. Mineral. Mag. 58 A: 889-890, 1994.

Takazawa E., Frey F. A., Shimizu N., Yoshikawa M. and Nakamura E., Geodynamic evolution of the Horoman peridotite, Hokkaido, Japan, based on the geochemical studies of a a $40 \mathrm{~m}$ stratigraphic section. Abst. 2nd Int. Workshop on Orogenic Lherzolites and Mantle Processes, Granada p 68-69, 1995.

Takazawa E., Frey F. A., Shimizu N. and Obata M., Evolution of the Horoman peridotite (Hokkaido, Japan): Implications from pyroxene compositions. Chem. Geol. 134: 3-26, 1996.

Takazawa E. Geodynamic evolution of the Horoman peridotite, Japan: Geochemical study of lithospheric and asthenospheric processes. Ph.D thesis Massachusetts Institute of technology, 1996.

Takazawa E., Frey F. A., Shimizu N., Saal A. E. and Obata M., Polybaric petrogenesis of mafic layers in the Horoman peridotite complex, Japan. J Petrology (accepted for publication) 1999a.

Takazawa E., Frey F. A., Shimizu N. and Obata M. Whole-rock compositional variations in an upper mantle peridotite (Horoman, Hokkaido, Japan): Implications for melt segregation, migration and reaction. Geochim Cosmochim. Acta (accepted with revisions) $1999 \mathrm{~b}$. 
Walker R. J., Carlson R. W., Shirey S. B. and Boyd F. R., Os, Sr, Nd and Pb isotope systematics of southern African peridotite xenoliths: Implications for the chemical evolution of subcontinental mantle. Geochim Cosmochim. Acta, 53: 1583-1595, 1989.

Yoshikawa M., Nakamura E. and Takahashi N., Rb-Sr isotope systematics in a phlogopite-bearing spinel therzolite and its implications for age and origin of metasomatism in the Horoman peridotite complex, Hokkaido, Japan. J. Min. Petrol. and Econ. Geol. 88: $121-130,1993$.

Yoshikawa M. and Nakamura E., Geochemical evolution of the Horoman peridotite complex: Implications for melt extraction, metasomatism and compositional layering in the mantle. J. Geophys. Res (under review) 1999. 


\subsection{Table caption}

Table 1: Re and Os concentration and Os isotopic composition of 20 samples from the Horoman Peridotite. $\mathrm{T}_{\mathrm{MA}}$ are model ages calculated with respect to "primitive upper mantle" ${ }^{187} \mathrm{Re} /{ }^{188} \mathrm{Os}=0.428$ and ${ }^{187} \mathrm{Os} /{ }^{188} \mathrm{Os}=0.1290$ (Meisel et al., 1996; McDonough and Sun, 1995 ) and a decay constant of $1.64 \times 10^{-11} \mathrm{y}^{-1} \cdot \mathrm{T}_{\mathrm{RD}}$ are Re depletion model ages assuming ${ }^{187} \operatorname{Re} /{ }^{188} \mathrm{Os}=0$

\subsection{Figure Caption}

Figure 1: Simplified geologic map of the Hidaka metamorphic belt. After Komatsu et al., 1986; Takazawa et al., 1999a.

Figure 2: Geologic map of the Horoman peridotite. Note the position of the Bozu section in the Lower Zone. The Boundary between the Lower and the Upper Zone is marked by a dashed line. Inset shows the location of the studied area. After Takazawa et al., 1999a.

Figure 3: a) Degree of melting along the Bozu section, Horoman peridotite. Dashed vertical lines indicate the contacts between lithologies. The shaded regions in the middle of both therzolite and plagioclase therzolite layers stand for phlogopite-bearing lherzolite and E-Type plagioclase therzolite respectively. The extent of melting is calculated by mass balancing the $\mathrm{FeO}$ and $\mathrm{MgO}$ contents between initial source and residual peridotite for each analyzed sample. Figure after Takazawa et al. (1999b); Takazawa (1996). b) Chondrite normalized REE contents for representative harzburgite (BZ-125L), lherzolite (BZ-143) and $\mathrm{E}$ and $\mathrm{N}$-type plagioclase lherzolite (BZ-260 and BZ-253 respectively) from the Bozu section. Symbols as in Figure 3a. C1 chondrite values from Anders and Grevesse (1989). Data from Takazawa et al., (1999b). Open circle, N-type plagioclase lherzolite; close circle, E-type plagioclase lherzolite; open square, lherzolite; crossed square, harzburgite.

Figure 4: a) ${ }^{187} \mathrm{Os} /{ }^{188} \mathrm{Os}$ in Horoman peridotites and in peridotites from different orogenic Iherzolite massifs, compiled by Roy-Barman et al. (1996). Note that the range in Os isotopic composition obtained in a 140 section from the Horoman massif is similar to that observed in the compilation of other peridotite massifs (compilation does not include mafic layers). b) ${ }^{187} \mathrm{Os} /{ }^{188} \mathrm{Os}$ versus distance along the Bozu section. Note that the extreme variation in $\mathrm{Os}$ isotopic composition occurs between an $\mathrm{E}$ - and $\mathrm{N}$-Type plagioclase lherzolites separatedby only $5 \mathrm{~m}$. Symbols as in Figure 3. 
Figure 5: ${ }^{187} \mathrm{Os} /{ }^{188} \mathrm{Os}$ versus degree of melting for samples from the Bozu section. The inverse correlation between Os isotopes and the extent of melt depletion indicate that both parameters are related by a single process: melting or refertilization of a depleted peridotite. The extent of depletion is calculated by mass balancing the $\mathrm{FeO}$ and $\mathrm{MgO}$ contents between initial source and residual peridotite (Takazawa et al., 1999b).

Figure 6: ${ }^{187} \mathrm{Os} /{ }^{188} \mathrm{Os}$ ratios, $\mathrm{Re}$ and Os contents versus $\mathrm{MgO}$ content for samples from the Bozu section, Horoman peridotite. The samples define a negative correlation between $\mathrm{Re}$, Os isotopes and $\mathrm{MgO}$, but show no correlation between $\mathrm{MgO}$ and Os contents. This figure suggests that Re behaves as an incompatible element, while Os is highly compatible. Moreover, the negative correlation between ${ }^{187} \mathrm{Os} /{ }^{188} \mathrm{Os}$ and $\mathrm{MgO}$ indicates that the Os isotopes are controlled by $\mathrm{Re}$ content through ingrowth.

Figure 7: ${ }^{187} \mathrm{Os} /{ }^{188} \mathrm{Os}$ ratios, $\mathrm{Al}_{2} \mathrm{O}_{3}, \mathrm{Yb}, \mathrm{Sc}$ contents and modal clinopyroxene versus $\mathrm{Re}$ content. The observed correlations indicate that the variation in ${ }^{187} \mathrm{Os} /{ }^{188} \mathrm{Os}$ ratios is controlled by Re content through ingrowth, and the Re content is controlled by the variation in the proportion of "basaltic component" of the peridotite. Modal proportions of clinopyroxene (in \%) have been calculated by mass balancing the mineral compositions with that of the whole rock (Takazawa et al., 1999b). Dashed line represents Re and Os content for PUM. Doted square represent the composition of the PUM. Data from McDonough and Sun (1995).

Figure 8: ${ }^{187} \mathrm{Os} /{ }^{188} \mathrm{Os}$ versus ${ }^{187} \mathrm{Re} /{ }^{188} \mathrm{Os}$. The samples define a rough positive correlation with an apparent "age" of $1.04 \pm 0.4) \mathrm{Ga}$. (2o, York regression). Five N-Type plagioclase Iherzolites have high ${ }^{187} \mathrm{Re} /{ }^{188} \mathrm{Os}$ ratios plotting to the right of the geochron. Values for PUM and Geochron from Meisel et al. (1996). Values for Chondrite and Geochron from Smoliar et al. (1996). Dashed line as drawn infers a second stage deviation from a depleted mantle; the isochron cross the geochron at a lower values than that for present PUM, indicating that if the age of $1 \mathrm{Ga}$ represents a melting event, the mantle source is a depleted mantle.

Figure 9: Frequency diagram for Re depletion model ages for Horoman peridotite. The model ages were calculated using PUM values ${ }^{187} \mathrm{Re} /{ }^{188} \mathrm{Os}=0.428$ and ${ }^{187} \mathrm{Os} /{ }^{188} \mathrm{Os}=$ 0.1290 (Meisel et al., 1996). The Re depletion model ages reach values of up to $\approx 1.8 \mathrm{Ga}$., much older than the ages previously reported based on $\mathrm{Nd}$ isotopes. The $\mathrm{Re}$ depletion model ages should be considered as minimum ages. 
Figure 10: ${ }^{187} \mathrm{Os} /{ }^{188} \mathrm{Os}-{ }^{188} \mathrm{Re} /{ }^{188} \mathrm{Os}$ isochron diagram for Horoman samples including the two Type I mafic layers. All of the samples define an apparent "age" of $1.16 \pm 0.28 \mathrm{Ga}$ (York regression), similar to the $\approx 1 \mathrm{Ga}$ ages detemined using $\mathrm{Nd}$ isotopes (Yoshikawa and Nakamura, 1999; Takazawa 1996). The colinearity between the mafic layers and the ultramafic rocks, especially for those plagioclase therzolite plotting to the right of the geochron (see inset) suggest that the mafic and ultramafic rocks are genetically linked.

Figure 11: Primitive mantle normalized trace and major element contents for representative samples of the N-Type plagioclase lherzolite, E-Type plagioclase lherzolite and Type I mafic layers. We have also plotted the average for both the depleted E-Type plagioclase lherzolite and the mafic layers used as end-member in the mixing models (thick lines in gray). Note that in the depleted end-member (E-Type plagioclase lherzolite), the elements more incompatible that $\mathrm{Eu}$ have been modified (enriched) by metasomatic processes. Data from Takazawa et al., (1999a; 1999b). Plagioclase therzolite E-Type (BZ260); N-Type (BZ-250, BZ-254, BZ-256 and 62210); mafic layer (G2). Primitive Mantle values from McDonough and Sun, (1995).

Figure 12: $\mathrm{Cm}$-Ca versus $\mathrm{Cb}-\mathrm{Ca}$. diagram to determine the proportion of the end member component in a mixture (Cantagrel et al., 1984). Each point represents one element used in the mixing model. $\mathrm{Cm}, \mathrm{Ca}, \mathrm{Cb}$ are the concentrations of each element in the mixture $(\mathrm{N}-$ Type plagioclase lherzolite), the depleted peridotite (E-Type plagioclase lherzolite) and in the mafic layer (Type I) respectively. "Xb" represents the slope of the line, which is the proportion of the mafic layer in the mixture.In this case we used one variable regression.

Figure 13: Calculated trace and major element contents from the mixing model, normalized by their measured value for each of the N-Type Plagioclase Lherzolites. Note that with the exception of $\mathrm{P}$ and $\mathrm{K}$, the model reproduces the values for major and trace elements more compatible than $\mathrm{Eu}$. We used the same end-members for all the samples, changing only the proportion of mafic layers in the mixture.

Figure 14: Re-Os isochron diagrams for a) Ronda, b) Beni Bouseras and Lanzo, and c) Pyrenees peridotites and mafic layers. In all of these cases, the most fertile peridotites in each massif have high ${ }^{188} \mathrm{Re} /{ }^{188} \mathrm{Os}$, plotting to the right of the geochrone. Moreover, the mafic layers are colinear with the peridotites in each massif, suggesting that the mafic and ultramafic rocks are genetically related probably through refertilization processes. The case of Ronda is interesting, where garnet-rich bands, believed to be disaggregated garnet- 
bearing mafic layers, plot as the most fertile end member of the linear trend defined by the peridotites. Therefore, if the age has any significance, it may indicate the age of refertilization as in the case of the Horoman massif. 
Table 1

\begin{tabular}{|c|c|c|c|c|c|c|c|c|}
\hline Sample \# & Distance $(m)$ & $\operatorname{Re}(\mathrm{ppb})$ & Os (ppb) & $\mathrm{Re} / \mathrm{Os}$ & ${ }^{187} \mathrm{Os} /{ }^{188} \mathrm{Os}$ & ${ }^{187} \mathrm{Re} /{ }^{188} \mathrm{Os}$ & $\mathrm{T}_{\mathrm{RD}}(\mathrm{Ga})$ & $T_{M A}(G a)$ \\
\hline \multicolumn{9}{|l|}{ Plagioclse Lherzolite } \\
\hline N-Type Bz-263 & 132 & 0.205 & 4.57 & 0.045 & 0.1240 & 0.217 & 0.71 & 1.44 \\
\hline N-Type Bz-262 & 127 & 0.288 & 2.89 & 0.100 & 0.1253 & 0.480 & 0.53 & -4.54 \\
\hline N-Type Bz-261 & 120 & 0.318 & 3.22 & 0.099 & 0.1259 & 0.476 & 0.44 & -4.12 \\
\hline E-Type Bz-260 & 117 & 0.099 & 5.18 & 0.0191 & 0.1200 & 0.0918 & 1.27 & 1.61 \\
\hline E-Type Bz-259 & 115 & 0.147 & 3.11 & 0.047 & 0.1210 & 0.228 & 1.14 & 2.41 \\
\hline E-Type Bz-258 & 109 & 0.154 & 2.92 & 0.053 & 0.1201 & 0.254 & 1.25 & 3.04 \\
\hline E-Type Bz-257 & 103 & 0.151 & 4.65 & 0.0324 & 0.1158 & 0.156 & 1.86 & 2.90 \\
\hline N-Type Bz-256 & 101 & 0.353 & 2.91 & 0.121 & 0.1267 & 0.585 & 0.32 & -0.89 \\
\hline N-Type Bz-255 & 97.7 & 0.270 & 3.48 & 0.077 & 0.1283 & 0.373 & 0.10 & 0.79 \\
\hline N-Type Bz-254 & 94.7 & 0.253 & 3.12 & 0.081 & 0.1226 & 0.391 & 0.90 & 9.66 \\
\hline N-Type Bz-253 & 89.3 & 0.310 & 4.02 & 0.077 & 0.1256 & 0.371 & 0.48 & 3.51 \\
\hline N-Type Bz-252 & 87.9 & 0.318 & 4.50 & 0.071 & 0.1260 & 0.341 & 0.43 & 2.07 \\
\hline N-Type Bz-251 & 86.2 & 0.237 & 3.44 & 0.069 & 0.1235 & 0.332 & 0.78 & 3.40 \\
\hline N-Type Bz-250 & 84.3 & 0.223 & 2.44 & 0.092 & 0.1246 & 0.441 & 0.63 & -24.93 \\
\hline \multicolumn{9}{|l|}{ Lherzolite } \\
\hline 143 & 72.3 & 0.128 & 3.98 & 0.0322 & 0.1226 & 0.155 & 0.90 & 1.41 \\
\hline 134 & 39.9 & 0.143 & 4.24 & 0.0339 & 0.1190 & 0.163 & 1.40 & 2.25 \\
\hline $134 \mathrm{R}$ & & 0.161 & 4.31 & 0.0373 & 0.1196 & 0.180 & 1.32 & 2.27 \\
\hline \multicolumn{9}{|l|}{ Harzburgite } \\
\hline 116 & 9.1 & 0.0087 & 3.86 & 0.0022 & 0.1193 & 0.0108 & 1.37 & 1.41 \\
\hline 125 & 4.1 & 0.0066 & 4.61 & 0.0014 & 0.1207 & 0.0069 & 1.17 & 1.19 \\
\hline \multicolumn{9}{|l|}{ Type 1 Mafic Layers } \\
\hline G9 & & 0.233 & 0.035 & 6.65 & 0.788 & 34.8 & & 1.16 \\
\hline G2 & & 3.53 & 0.245 & 14.4 & 2.010 & 86.4 & & 1.32 \\
\hline
\end{tabular}




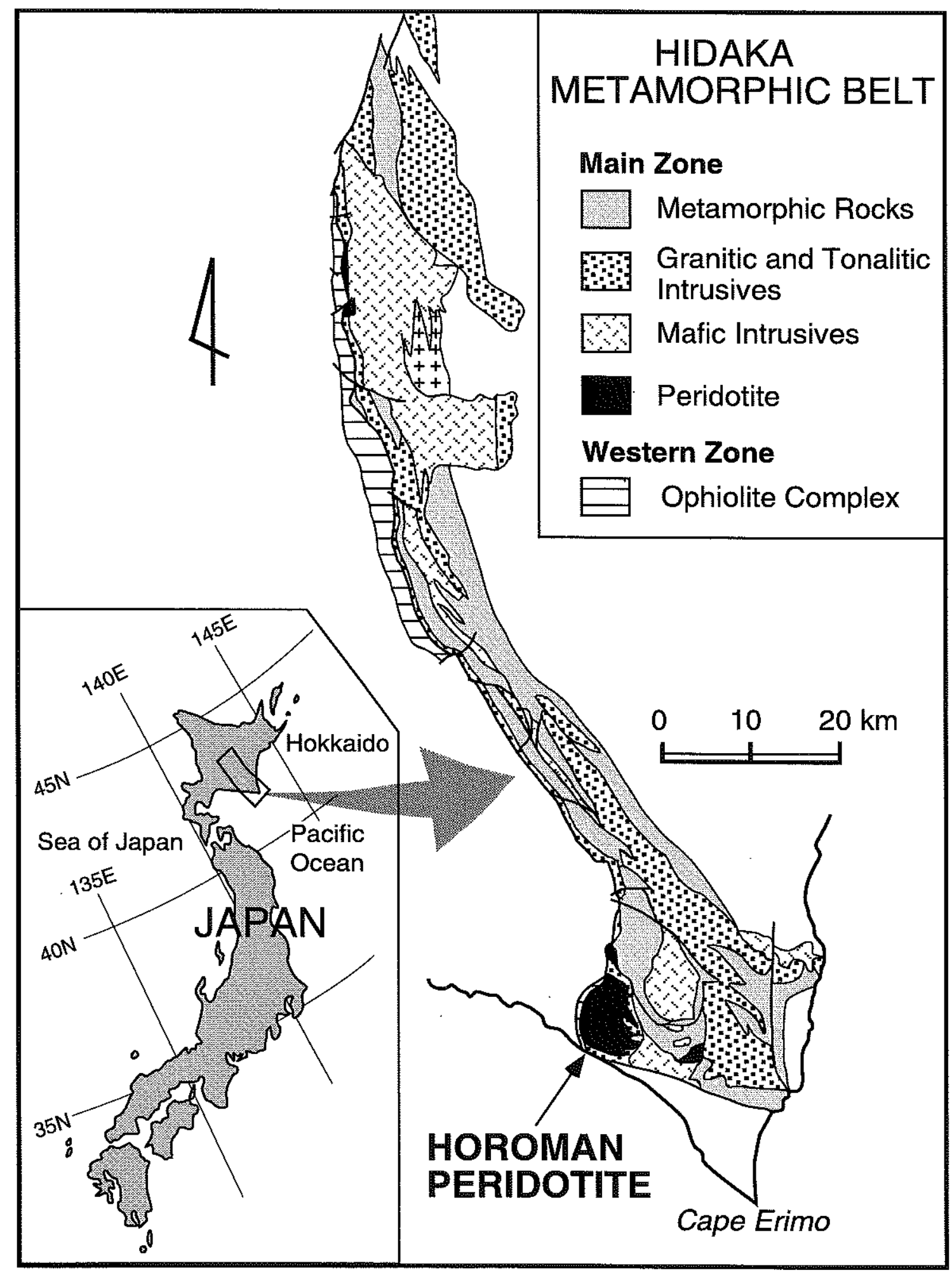

Figure 1 


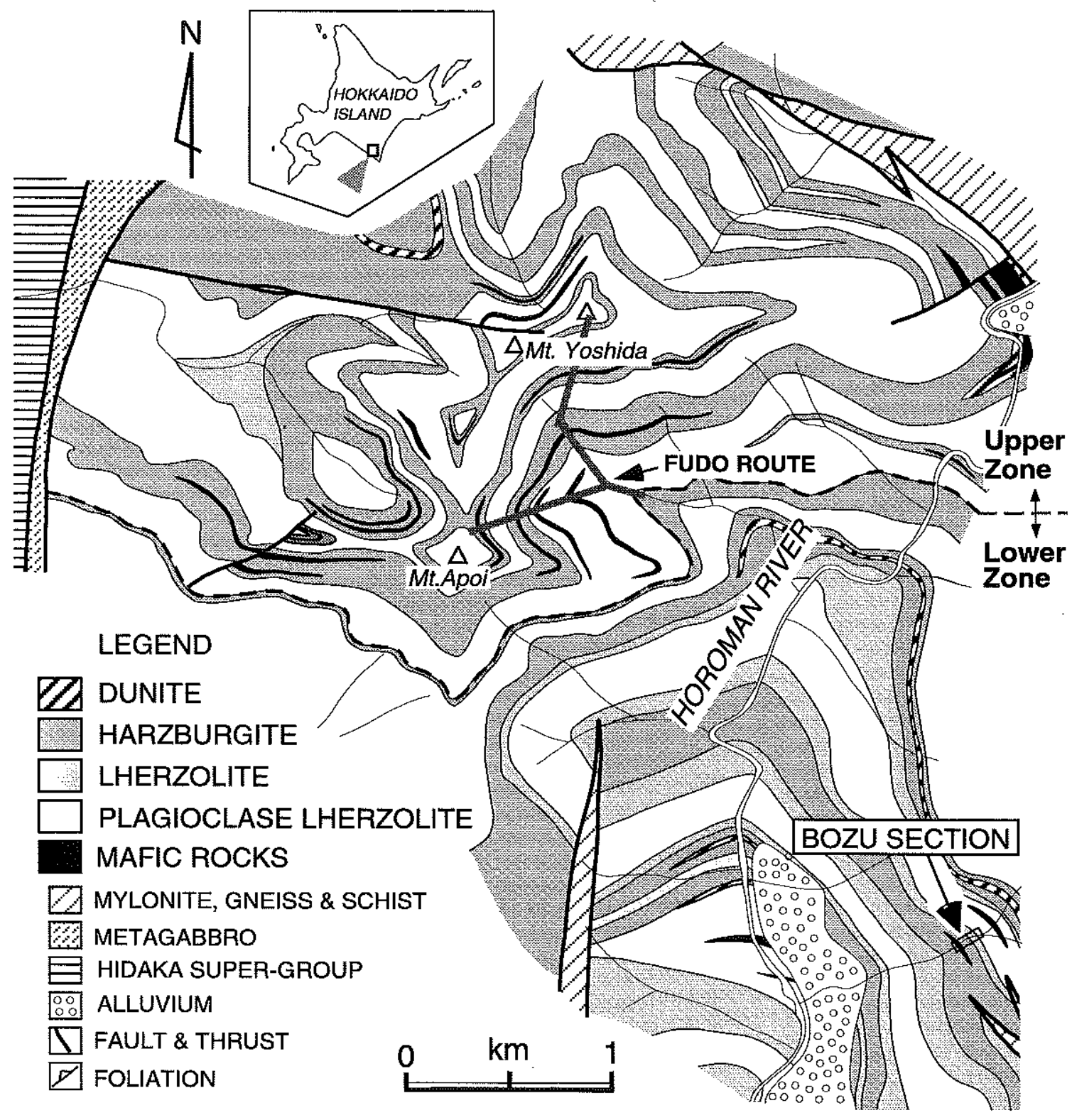

Figure 2 

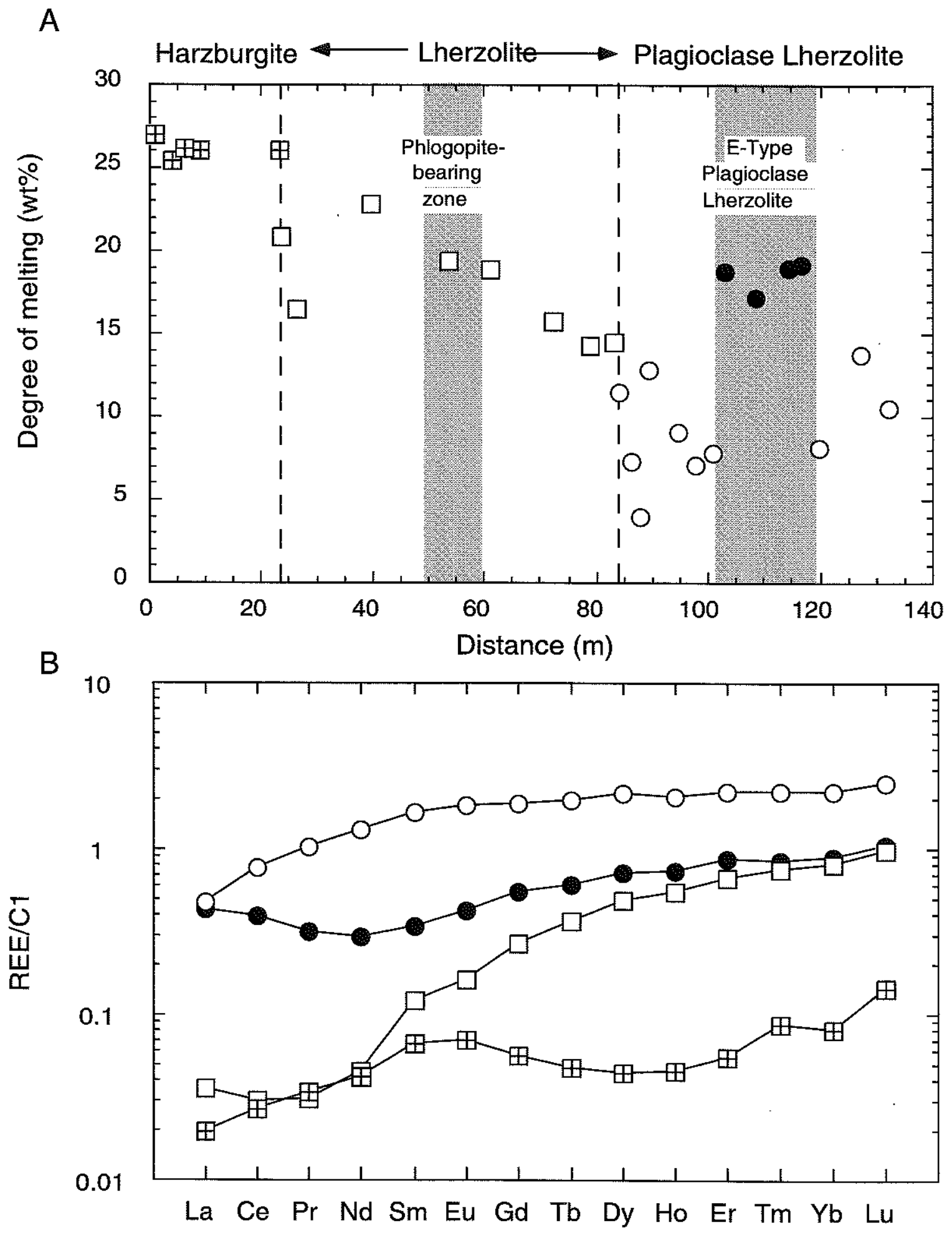

Figure 3 

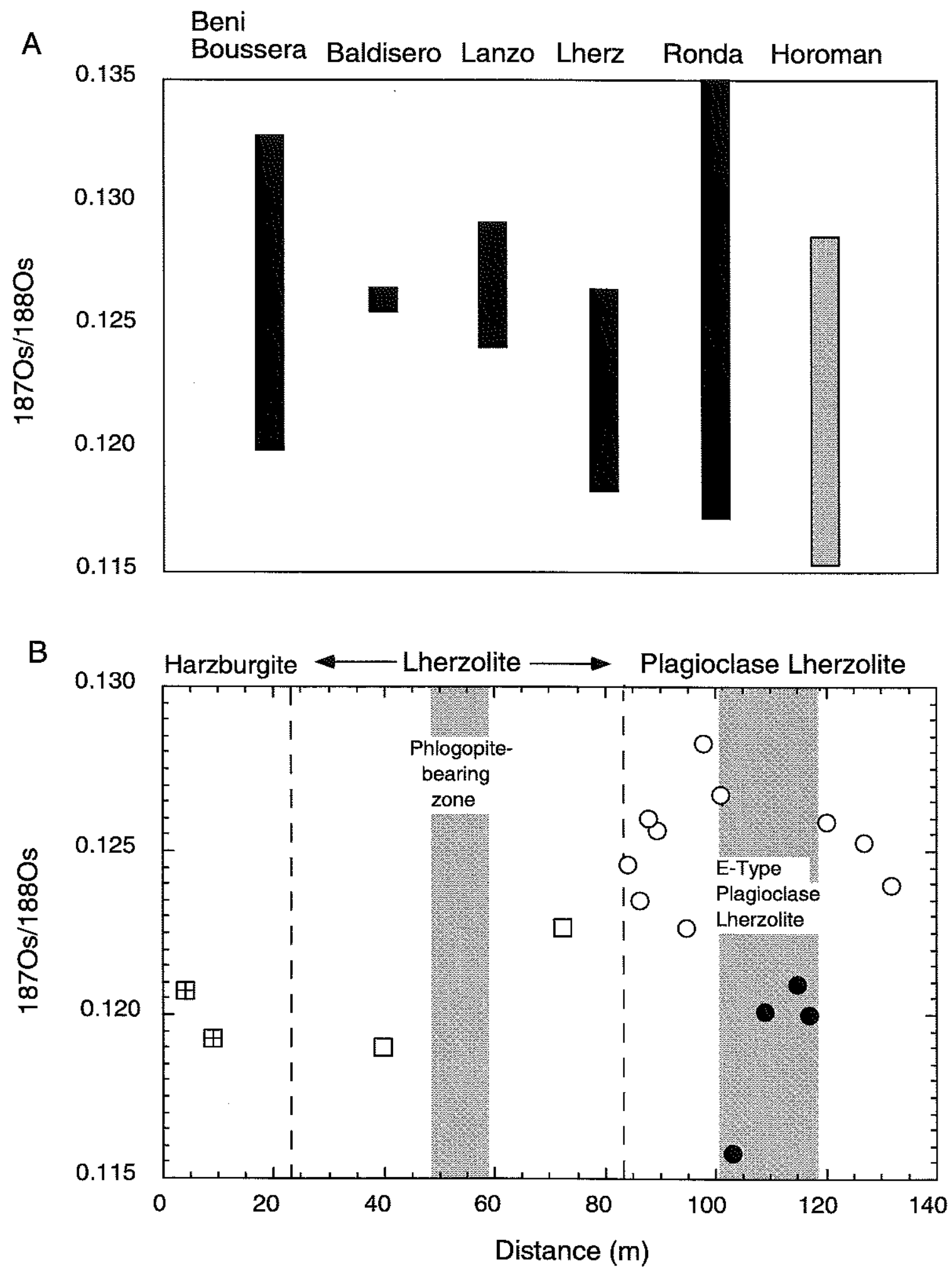

Figure 4 


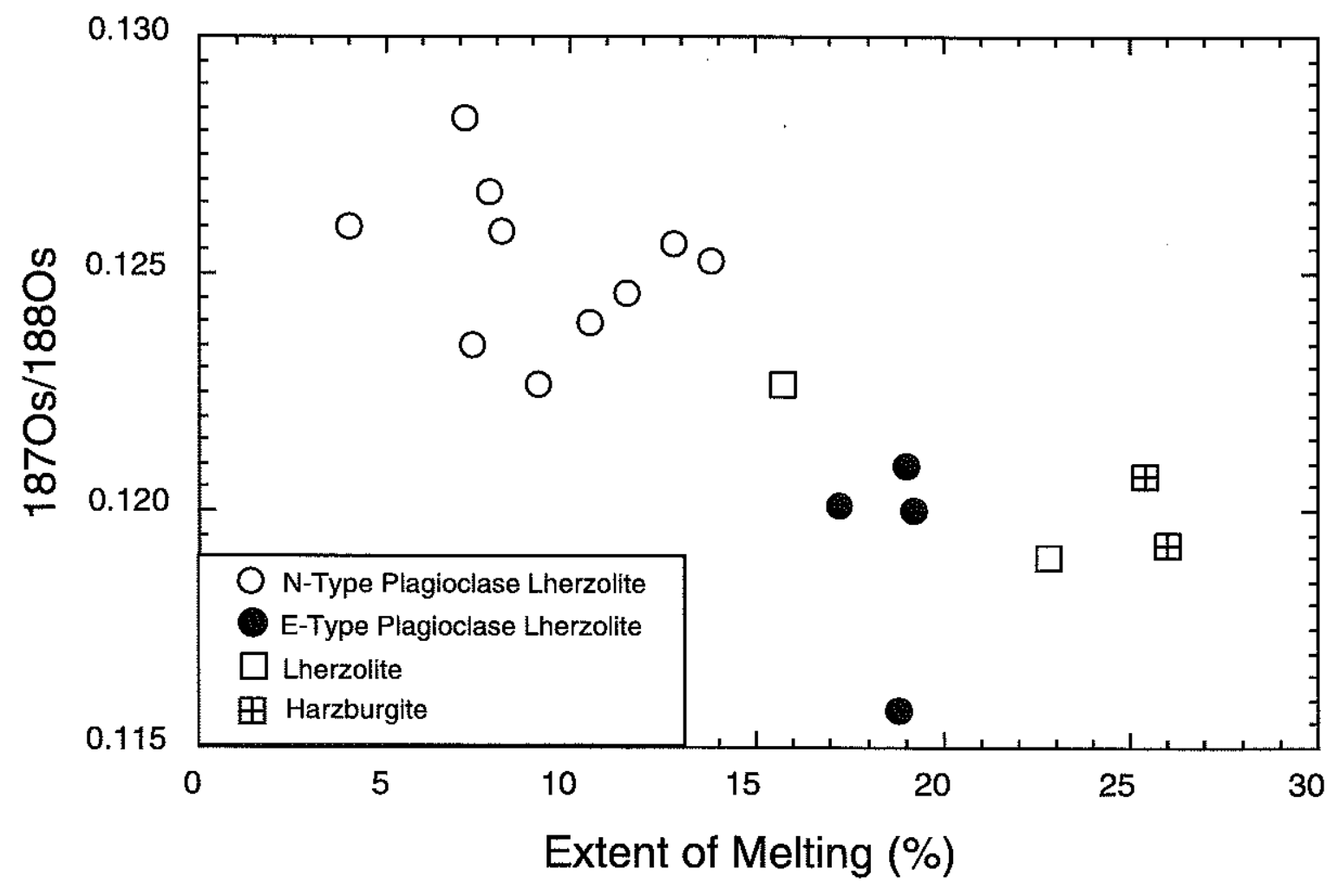

Figure 5 


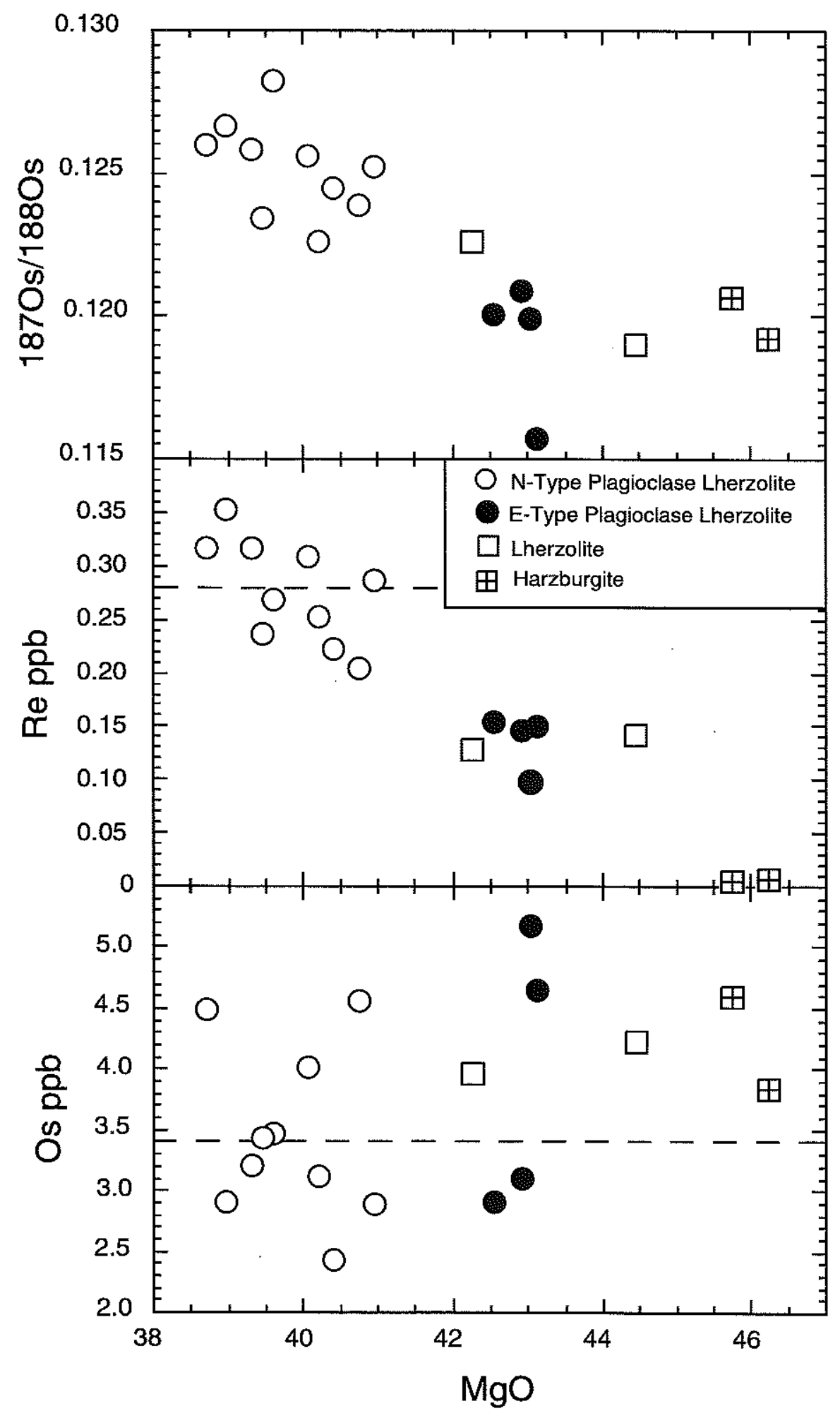

Figure 6 

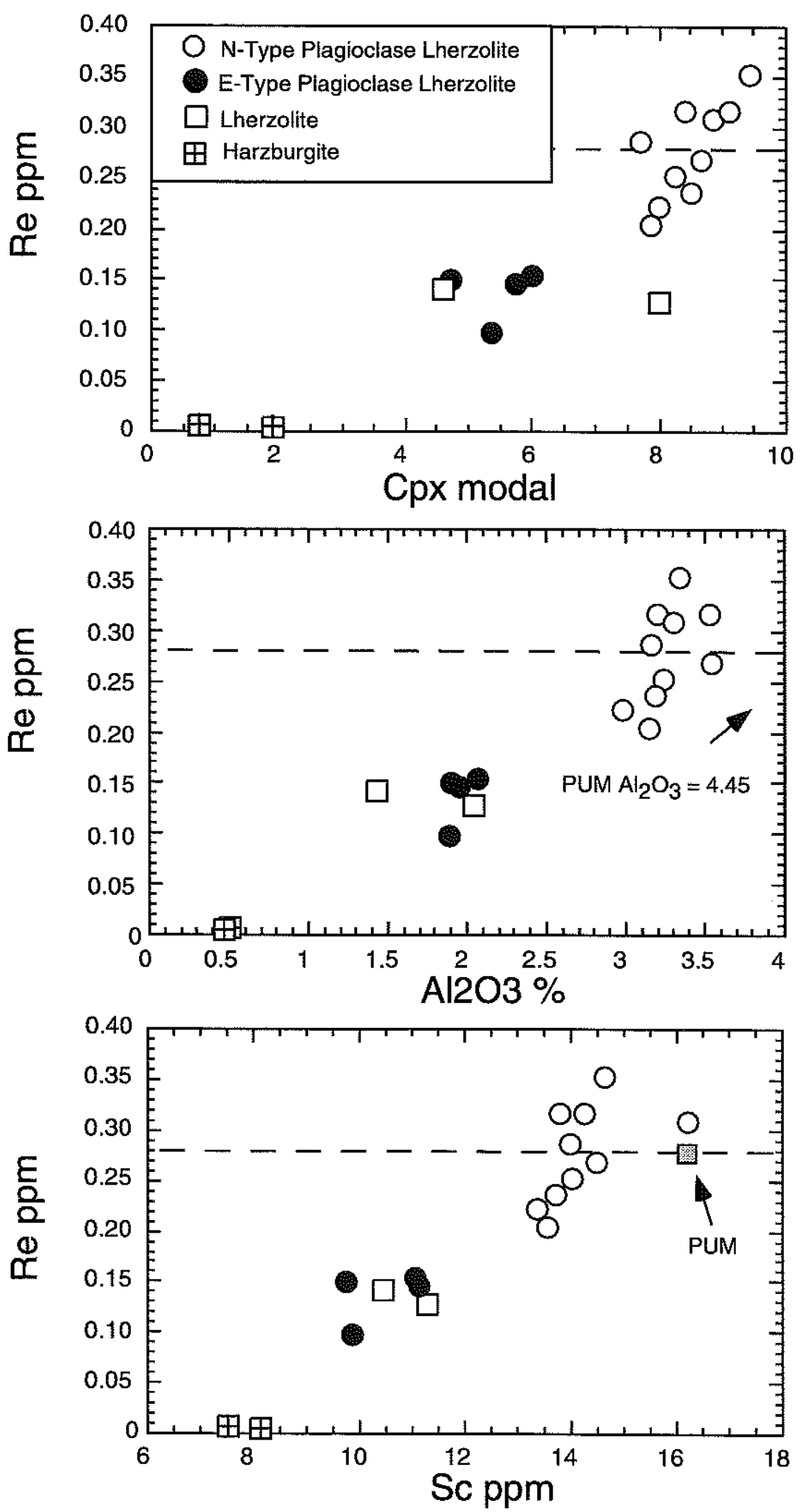

Figure 7 

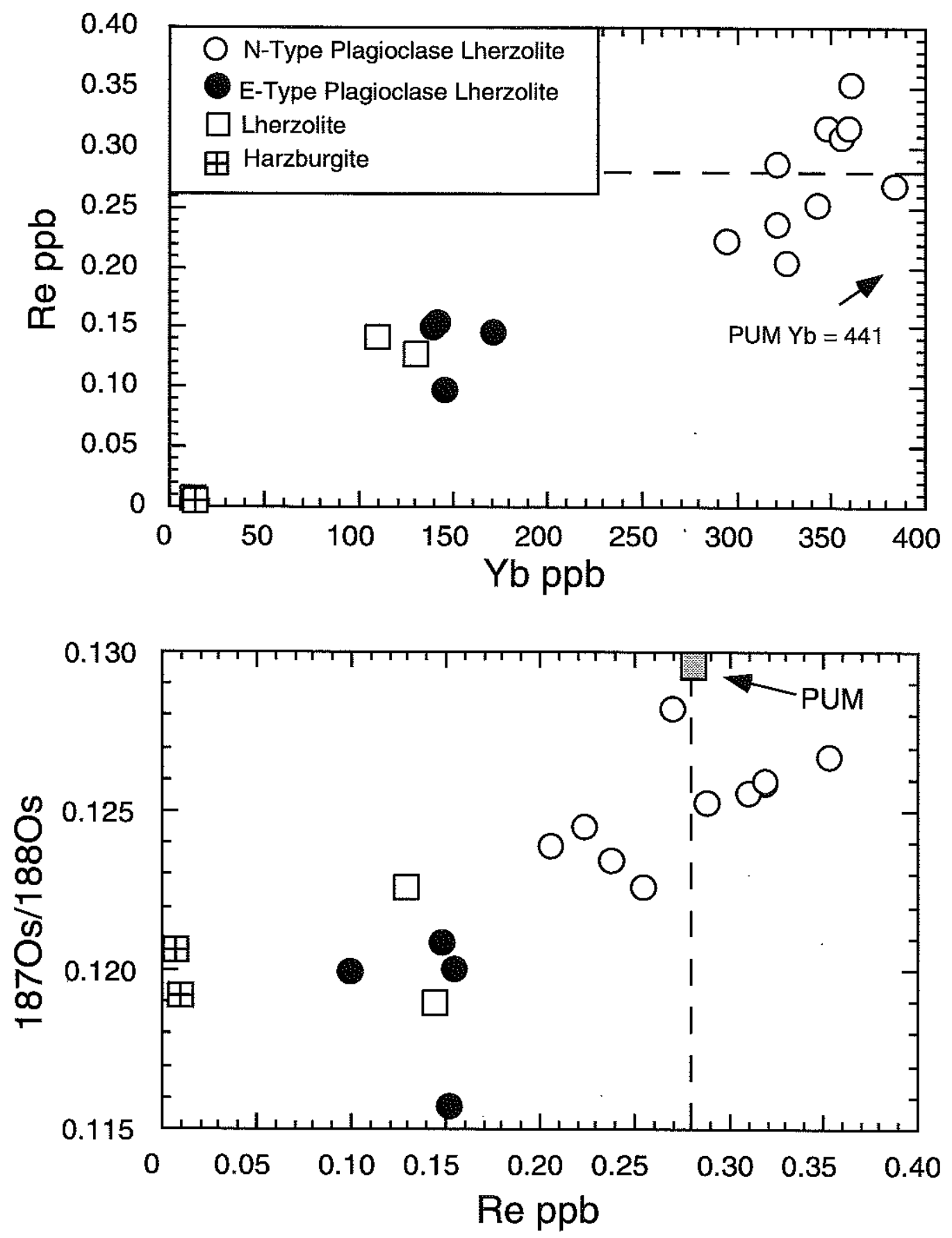

Figure 7 continuation 


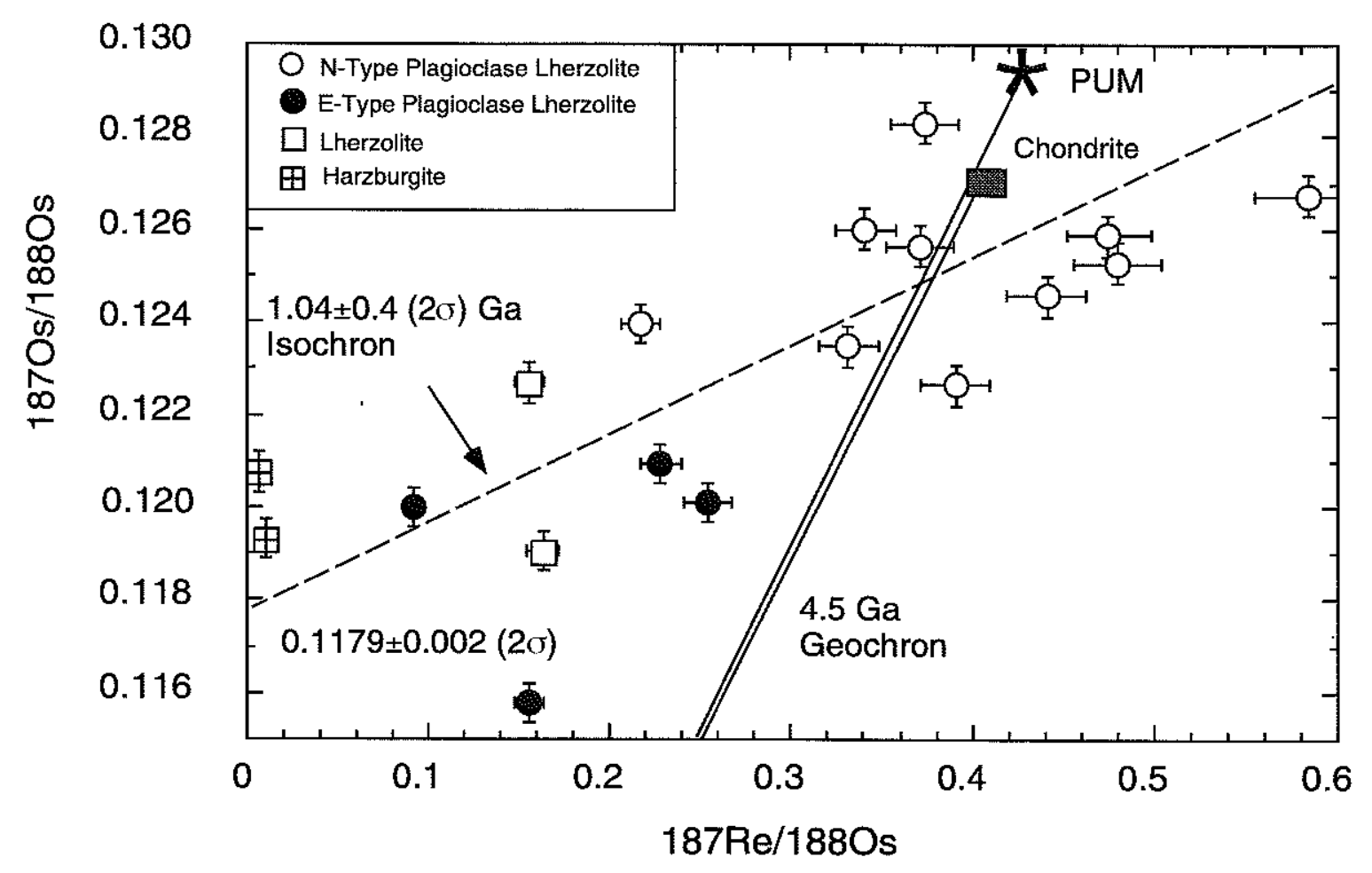

Figure 8 


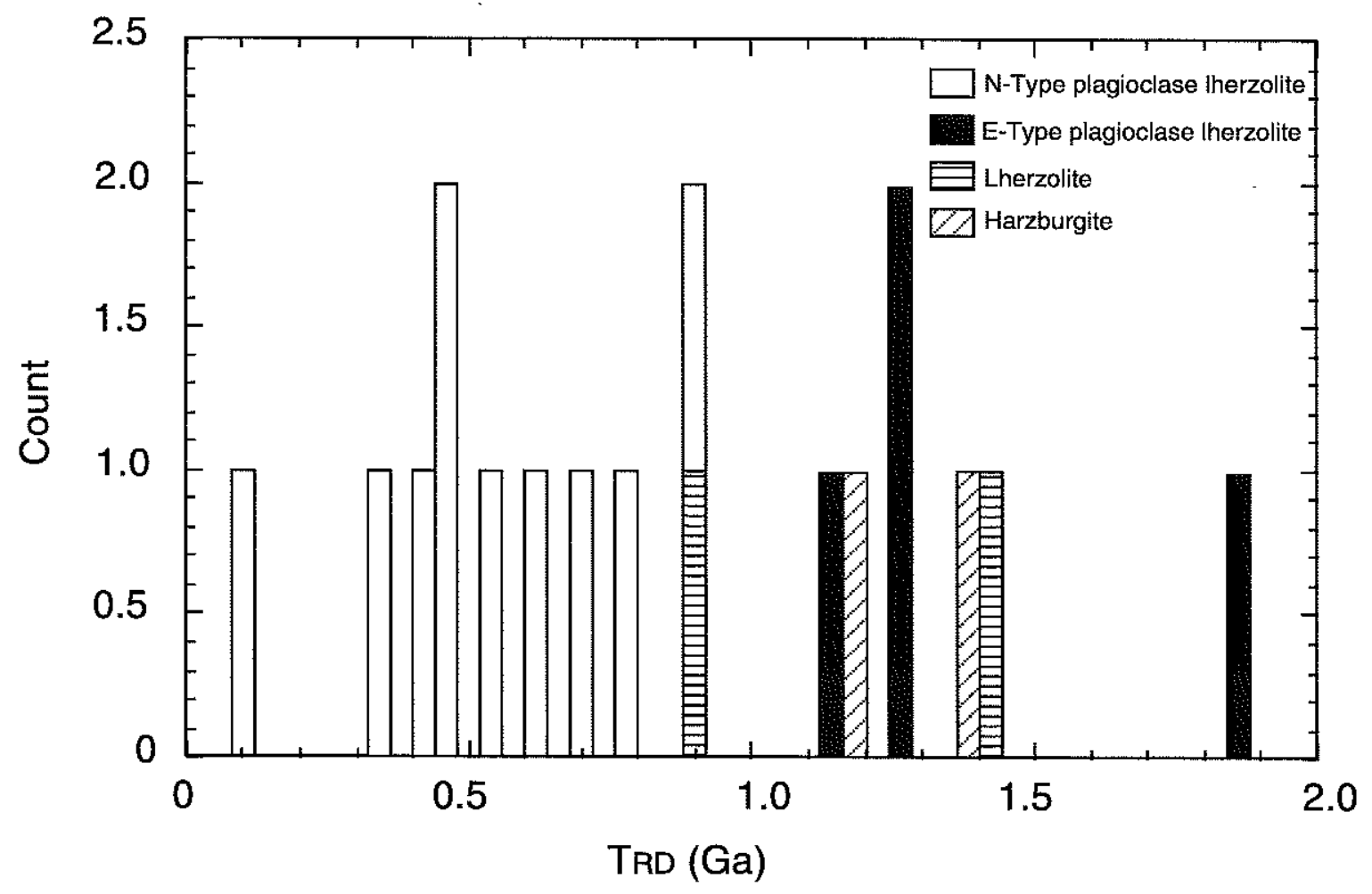

Figure 9 


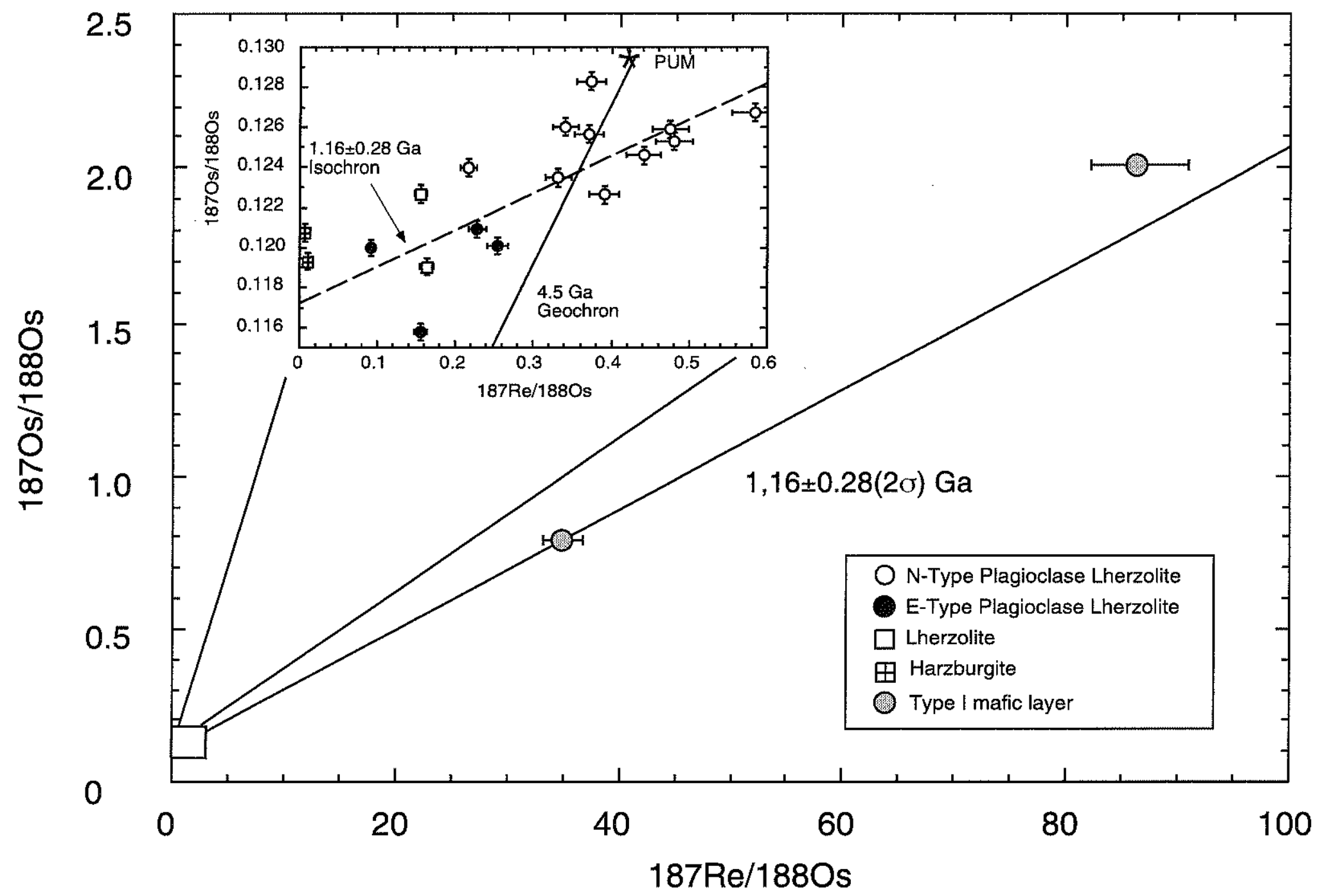

Figure 10 


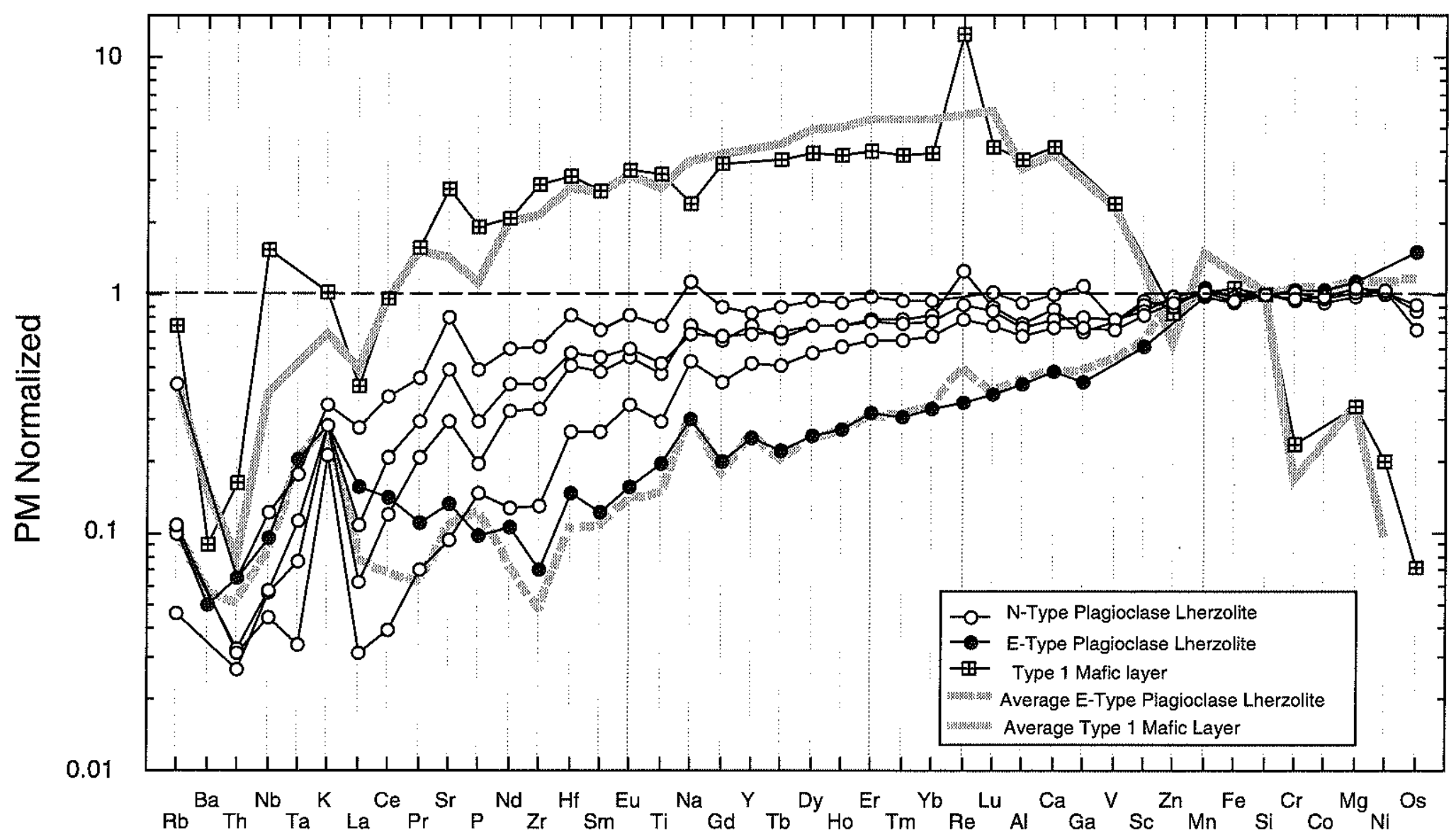

Figure 11 


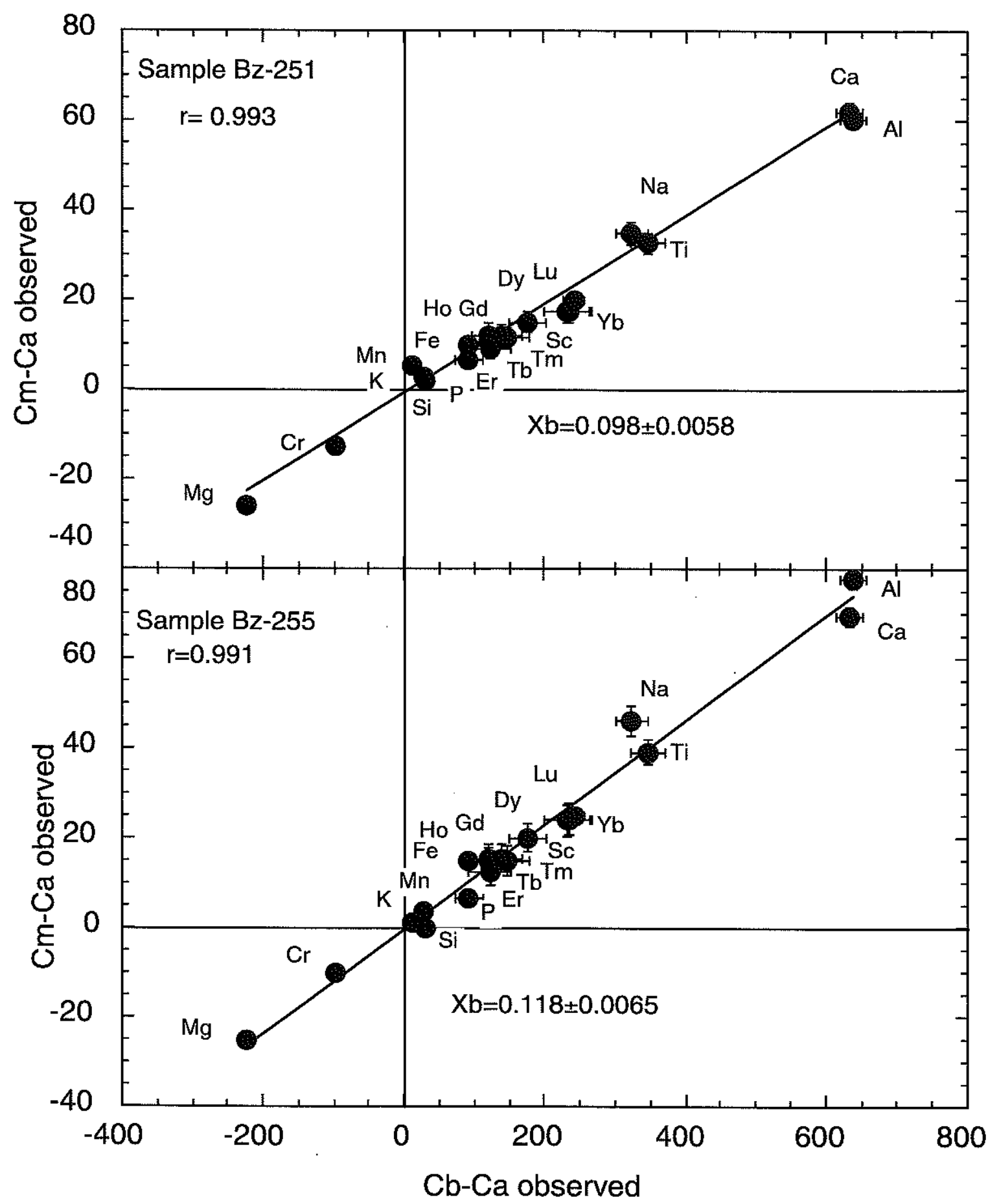

Figure 12 

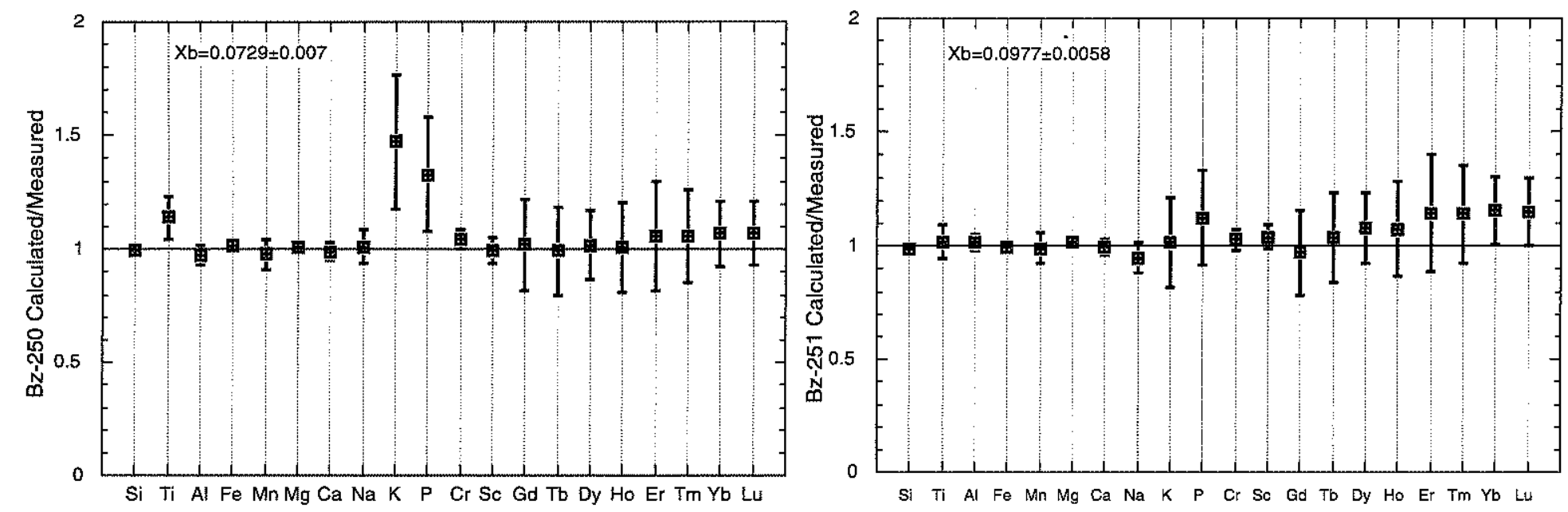

$\infty$
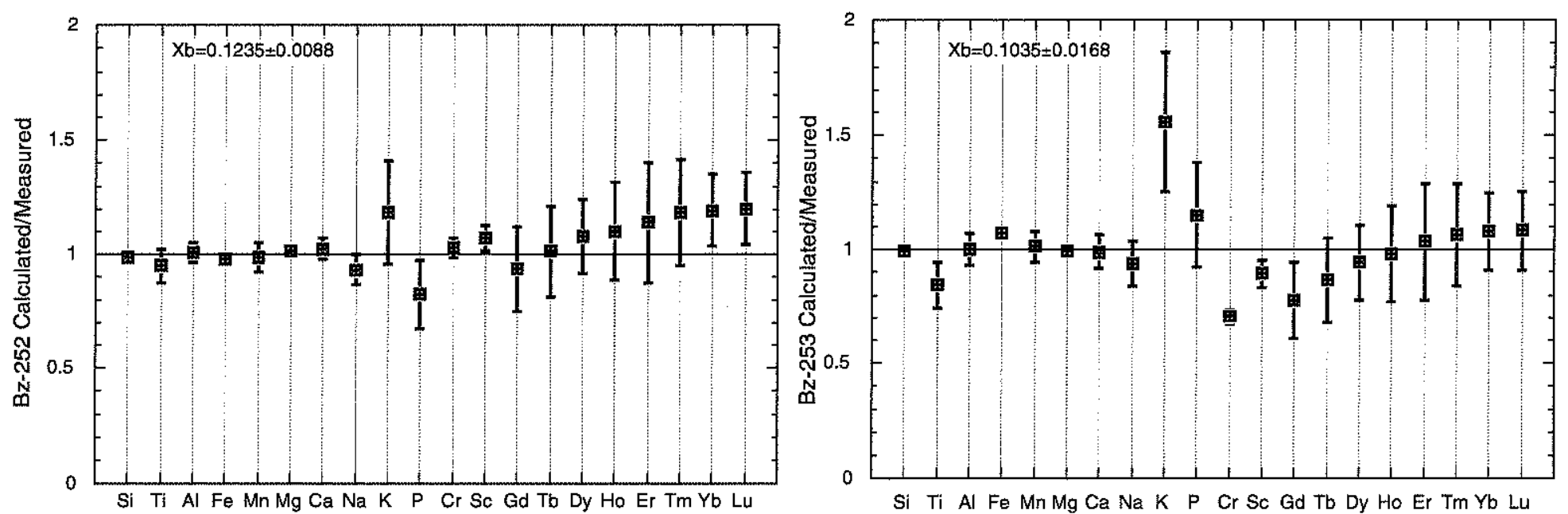

Figure 13 

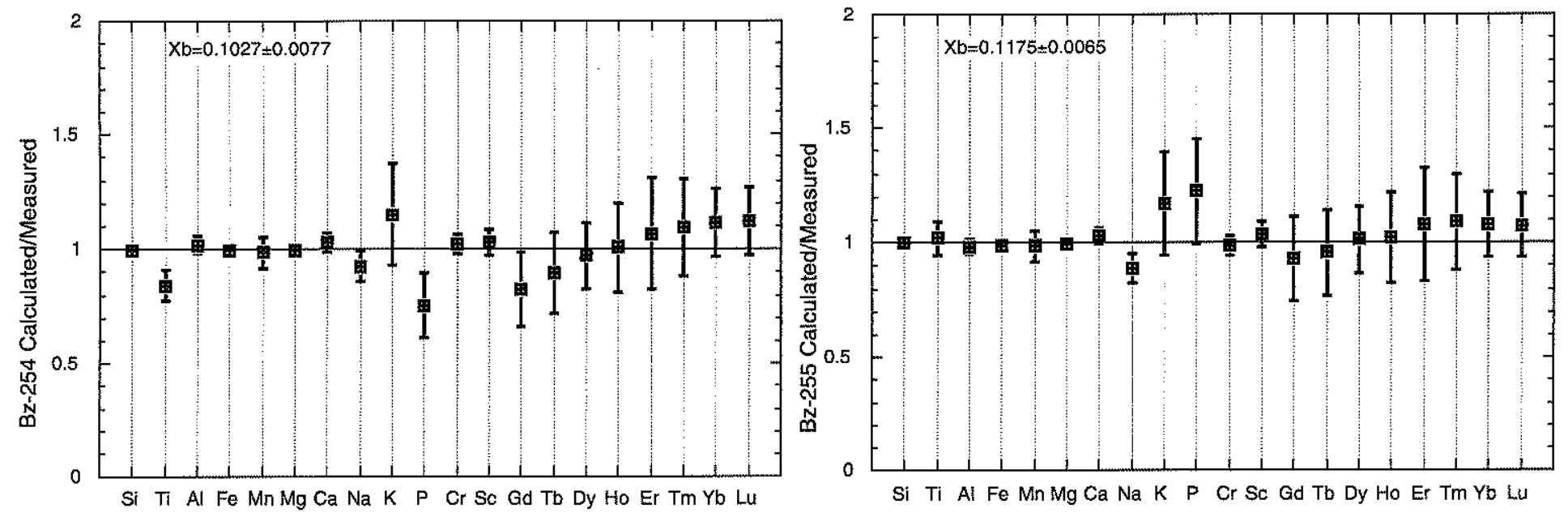

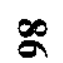
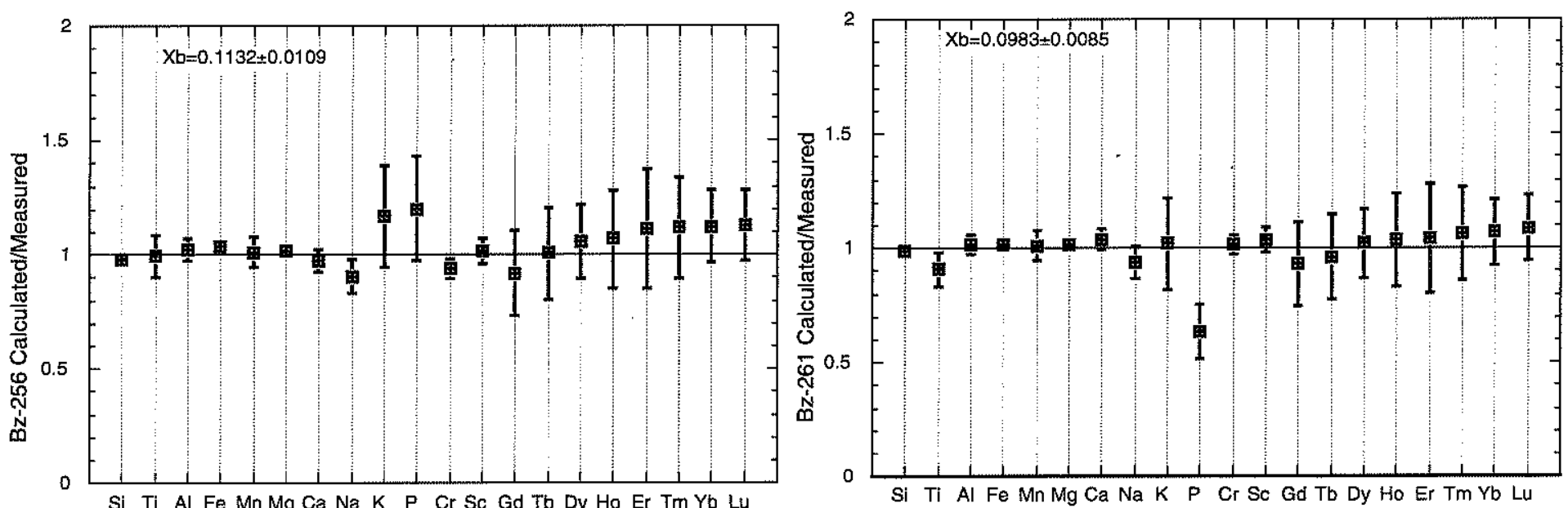

Figure 13

Continuation 

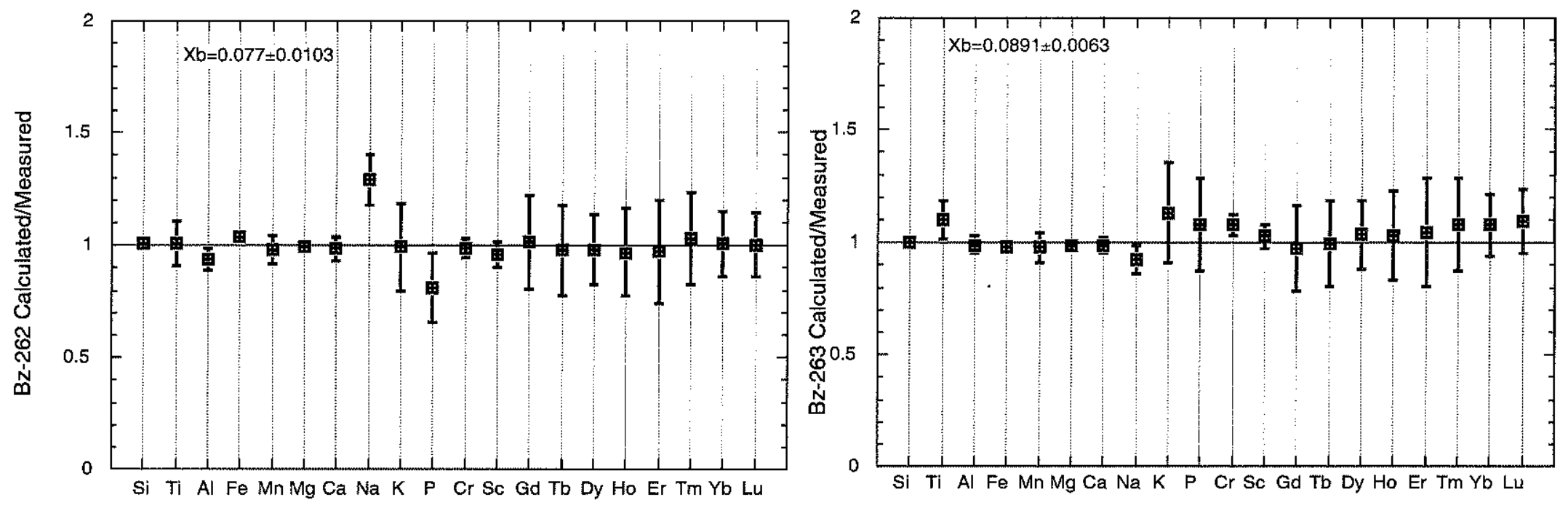

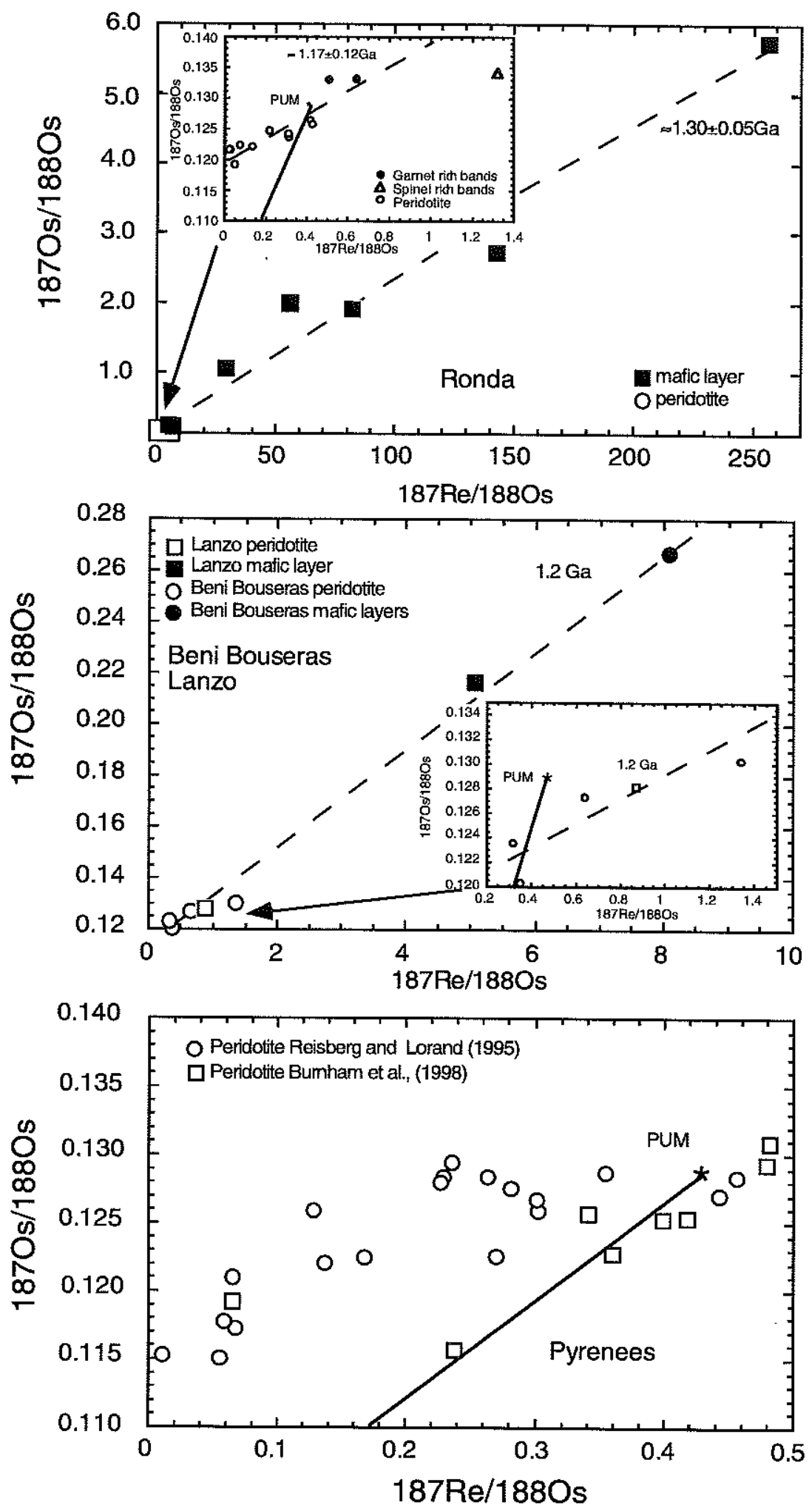

Figure 14 


\section{Chapter Three}

\section{Pb Isotopic Variability in Melt Inclusions from Oceanic Island Basalts}

\subsection{Abstract}

Previous studies have suggested that melting processes are responsible for the trace element variability observed in olivine-hosted basaltic melt inclusions. Melt inclusions from four individual lava samples, two from Mangaia, Cook Islands, one from Tahaa, Society chain, and one from Pitcairn, Gambier chain, have heterogeneous $\mathrm{Pb}$ isotopic composition, even though the erupted lavas are isotopically homogeneous. The range of $\mathrm{Pb}$ isotopic compositions from individual melt inclusions in a single lava flow spans $50 \%$ of the worldwide range observed for ocean island basalts (OIB). The melt inclusion data can be explained by two-component mixing for each island. Our data imply that magmas with different isotopic compositions existed in the volcanic plumbing system prior to or during melt aggregation.

\subsection{Introduction}

Studies of oceanic basalts have shown that the mantle is isotopically heterogeneous (Zindler and Hart, 1986; Hart et al, 1992; Hannan and Graham, 1996, Hofmann, 1997 and references therein). However, the nature, distribution, and scale of these heterogeneities remain uncertain. The aggregation of melts on their way to the surface, and mixing in magma chambers prior to eruption, can obscure the chemical and isotopic signatures of preaggregated melts.

Trace and major element studies of olivine-hosted melt inclusions have been successful in defining the chemical composition of pre-aggregated melts (Sobolev and Shimizu, 1993; Gurenko and Chaussidon, 1995, Sobolev et al., 1994a, 1994b; Nielsen, 1995, Kamenetsky, 1996; Sobolev and Danyushevsky, 1994; Schiano and Clocchiatti, 1994). However, the lack of isotopic information on melt inclusions has made it difficult to distinguish whether these melt compositions represent different extents of melting from a single source or whether they originate from different source compositions. 
We selected four geochemically well-characterized basalt samples, two from Mangaia, Cook Islands, one from Tahaa, Society islands, one from Pitcairn, Gambier chain, and two peridotitic xenoliths from Tubuaii, Austral chain, (Hauri et al., 1993; Hauri and Hart, 1993; 1997; Eiler, et al., 1995; Eiler, et al., 1997). The whole rock Sr, Nd and $\mathrm{Pb}$ isotopic compositions from Mangaia, Tahaa and Pitcairn islands are very similar to the three end-member mantle compositions known as the HIMU (high U/Pb ratios) EMII and EMI (enriched mantle) end-members respectively (Zindler and Hart, 1986; Hart et al., 1992). Previous studies reporting isotope, major and trace element compositions of these lavas have explained the observed geochemical variation by melting of single (homogeneous) mantle sources, originating through the recycling of the oceanic crust (Woodhead, 1996; Hemond et al., 1994, Eiler et al., 1997, Hauri et al., 1993; Hauri and Hart, 1993). Thus, these lavas are excelent examples on which to test the hypothesis that the geochemical variations in melt inclusions do in fact represent melt processes as opposed to source effects.

In this work, we present the first study of $\mathrm{Pb}$ isotopes on melt inclusions from the three mantle end-members: HIMU, EMI and EMII. The range in $\mathrm{Pb}$ isotopic composition observed in melt inclusions from single lava flows suggests that the geochemical variation in melt inclusions has a large component of source control, and is mainly produced by either mixing of melts or assimilation and fractional crystallization processes deep in the magma chambers.

\subsection{Analytical Techniques}

Approximately 100 grams of fresh interior of the basalt samples were crushed with a steel jaw crusher. The samples were sieved to separate the olivine and clinopyroxene phenocrysts (retaining grains larger than $1 \mathrm{~mm}$ ). The grains were washed with ultrapure water in an ultrasonic bath and dried at low temperature $\left(<80^{\circ} \mathrm{C}\right)$ in an oven. The olivines and clinopyroxenes with melt inclusions were selected under a binocular microscope, and mounted in an aluminum ring with epoxy and cured overnight. The grains where polished with silicon carbide, diamond and alumina powder until the melt inclusions were exposed. The mounts were cleaned with ethanol in ultrasonic bath for 5 minutes, dried at room temperature and placed in a vacuum chamber for at least 12 hours prior to the analysis. 
Major element compositions of host crystals and daughter minerals were measured on a JEOL 733 electron microprobe at the Massachusetts Institute of Technology (Table 1 and Appendix). We applied the correction methods of Bence and Albee (1968) and Albee and Ray (1970). The typical operating conditions used were an accelerating voltage of 15 $\mathrm{keV}$ and currents of $10 \mathrm{nAmps}$. Counting times ranges from 20 to 40 seconds. The in-run precision is mainly governed by counting statistics, varying with the abundance of the elements. For example, for a single analysis, the one sigma uncertainties are approximately $\leq 1 \%$ for element contents $\geq 1 \mathrm{wt}$. $\%, 1$ to $5 \%$ for $1-0.5 \mathrm{wt} \%, 5$ to $15 \%$ for $0.5-0.1 \mathrm{wt}$ $\%$ and $>15 \%$ for contents of less than $0.1 \%$. The melt inclusion and daughter and host mineral compositions reported are averages of two to four analyses. The spot size ranges from $5 \mu$ for the daughter minerals, to $10 \mu$ for the host minerals, and ranged from $10 \mu$ to $30 \mu$ for estimating the glass composition and the average melt inclusion composition respectively.

Trace element compositions for the melt inclusions were obtained by secondary ion mass spectrometry (SIMS) with a Cameca IMS $6 \mathrm{f}$ ion microprobe at the Department of Terrestrial Magnetism, Carnegie Institution of Washington and with the Cameca IMS $3 \mathrm{f}$ ion microprobe at the Woods Hole Oceanographic Institution, following the techniques of Shimizu and Hart, (1982) and Hauri et al., (1996) (Table 1 and Appendix). We used a primary ${ }^{16} \mathrm{O}^{-}$beam of 4.5 to $10 \mathrm{keV}$ and current ranging from 5 to $20 \mathrm{nAmps}$. The beam was focused to a spot of 10 to $20 \mu$. Energy filtering techniques, with secondary voltage offsets of -60 to -90 , were used to eliminate molecular ion interference and to reduce the magnitude of matrix effects. Counting times ranged from 5 to 30 seconds depending on the element abundance. The intensities of the secondary ions were normalized to that of ${ }^{30} \mathrm{Si}$. The acquisition of the intensities consist of an average of five cycles of alternating measurements from light to heavy mass elements, and the ${ }^{30} \mathrm{Si}$ intensity was measured at the beginning and at the end of each run. The trace element concentrations were determined using empirical working curves of intensities versus concentrations for well known standards. The analytical uncertainty for each analysis varies inversely with the intensity of the element considered, and ranged from $<5 \%$ to $30 \%$.

Lead isotopes were determined by secondary ion mass spectrometry (SIMS) with a Cameca IMS 1270 ion microprobe at the Woods Hole Oceanographic Institution (Table 2). We used a primary ion $\left({ }^{16} \mathrm{O}^{-}\right.$) beam of $22.5 \mathrm{keV}$ (nominal primary accelerating voltage of $12.5 \mathrm{keV}$, and secondary accelerating voltage of $10 \mathrm{keV}$ ) and currents ranging from 30 to 
$50 \mathrm{nAmps}$ focused into a spot 20 to $30 \mu \mathrm{m}$ in diameter. To resolve isobaric interferences, secondary ions were analyzed at a mass resolution of 3500 with no energy filtering (Figure 1). Each analysis comprised 200 to 400 cycles of alternating measurements of ${ }^{206} \mathrm{~Pb}(4 \mathrm{~s}$ counting), ${ }^{207} \mathrm{~Pb}$ (4 s counting), ${ }^{208} \mathrm{~Pb}(2 \mathrm{~s}$ counting) and background (1 s counting). The in-run precision inversely correlates with the $\mathrm{Pb}$ content of the sample; typical in-run precision for the $\mathrm{Pb}$ isotopic measurements $\left({ }^{207} \mathrm{~Pb} /{ }^{206} \mathrm{~Pb} ;{ }^{208} \mathrm{~Pb} /{ }^{206} \mathrm{~Pb}\right)$ ranged from $\approx 0.2 \%$ $\left(2 \sigma ;{ }^{208} \mathrm{~Pb}\right.$ count rates $\left.10,000 \mathrm{cps}\right)$ to $1.2 \%\left(2 \sigma ;{ }^{208} \mathrm{~Pb}\right.$ count rates $\left.200 \mathrm{cps}\right)$. When ${ }^{208} \mathrm{~Pb}$ counts rates were higher than $2,000 \mathrm{cps}$, we also measured ${ }^{204} \mathrm{~Pb}(8 \mathrm{~s}$ counting), with an in-run precision for ${ }^{206} \mathrm{~Pb} /{ }^{204} \mathrm{~Pb}$ ranging from $\approx 0.5 \%\left(2 \sigma ; 10,000 \mathrm{cps}\right.$ for $\left.{ }^{208} \mathrm{~Pb}\right)$ to $1.6 \%$ $\left(2 \sigma ; 2,000 \mathrm{cps}\right.$ for ${ }^{208} \mathrm{~Pb}$ ). We used Loihi glass $158-4 *$ previously analyzed by TIMS (Garcia et al., 1995) as a standard during the period of measurement of the melt inclusions. The $\mathrm{Pb}$ content of the Loihi glass is $\approx 3 \mathrm{ppm}$, similar to the $\mathrm{Pb}$ content of the melt inclusions. Typical ${ }^{208} \mathrm{~Pb}$ count rates were approximately $400 \mathrm{cps}$ per ppm of total $\mathrm{Pb}$. The average of ion probe analyses reproduced the TIMS value of the glass standard to within $<0.1 \%$ standard errors $(2 \sigma)$. The external precision $(2 \sigma)$ defined by the 34 runs on the Loihi standard is $\pm 0.66 \%\left({ }^{208} \mathrm{~Pb} /{ }^{206} \mathrm{~Pb}\right)$, and $\pm 0.50 \%\left({ }^{207} \mathrm{~Pb} /{ }^{206} \mathrm{~Pb}\right)$; these are essentially the same as the average internal precision of the 34 runs (Figure 2a, b and c). We carefully evaluated whether hydride or correlated errors in ${ }^{206} \mathrm{~Pb}$ played any role in the isotopic ratios measured; we found that the isotopic ratios are mainly controlled by counting statistics, with no effect of hydride or systematic error in ${ }^{206} \mathrm{~Pb}$. The mass fractionation for SIMS analysis was $<0.15 \%$ per amu, and was smaller than the in-run precision. Comparison of TIMS and SIMS $\mathrm{Pb}$ isotope data for basaltic glass, feldspar, chalcopyrite, and zircon indicate that instrumental mass fractionation is generally smaller than the precision of the analyses and that there are no resolvable matrix effects (Layne and Shimizu ,1997).

\subsection{Results}

\subsubsection{Major and trace element compositions}

We recovered olivine (Fo 84-89) and clinopyroxene-hosted melt inclusions from two primitive basalts from Mangaia. We selected olivines and clinopyroxenes from an ankaramite, (MGA-B-25), and olivines from a picrite, (MGA-B-47). All melt inclusions are in general ellipsoidal in shape and range from 30 to $300 \mu \mathrm{m}$ in the longest direction. Sometimes the inclusions have straight boundaries or rectangular habits resembling pseudomorphs after a single phase. All of the inclusions now contain "daughter minerals" 
such as Ti-augite, Cr-spinel, ilmenite, Ti-magnetite, kaersutite, sphene, apatite and phlogopite that crystallized after entrapment of the melt (Table 1 and Appendix). Some of the daughter minerals, such as $\mathrm{Cr}$-spinel and augite, are zoned becoming enriched in $\mathrm{Ti}$ toward the margin. The host olivine and clinopyroxene are also zoned close to the contact with the melt inclusions. The olivine becomes enriched in $\mathrm{Fe}$ and $\mathrm{Ca}$ and the clinopyroxene is enriched in $\mathrm{Ti}$ (Appendix). Sometimes crystallized daughter clinopyroxene or kaersutite forms a surface that separates the melt inclusion from the host olivine or clinopyroxene respectively (Figure $3 a$ and $b$ ).

Some melt inclusions $(\approx 7 \%)$ from both Mangaia samples are texturally very complex, containing co-existing silicate glasses, sulfide, and carbonate globules (Figure 3a). In many cases, the inclusions contain droplets of silicate glass within carbonate spherules, bounded by sharp, curved menisci. This texture is suggestive of processes related to carbonate-silicate liquid immiscibility (Kogarko et al., 1995) (Figure 3a). The carbonate spherules consist largely of calcium-iron-magnesium carbonates with minor alkalis. The carbonates are associated with $\mathrm{Ca}$ or $\mathrm{Mg}$-rich volatile-bearing silicate glasses (up to $15 \%$ volatiles) and phonolitic glasses. In addition, sulfide globules form part of the mineral association in these melt inclusions. The sulfides range in composition from chalcopyrite, pentlandite to pyrrothite (Table 1 and Appendix). The observed mineral associations, textures, and the major element compositions of the minerals, carbonates and silicate glasses in the Mangaia melt inclusions are similar to those described for carbonatesilicate melt pockets in carbonated peridotitic xenoliths such as those reported for Spitșbergen and the Canary Islands (Ionov et al., 1996; Kogarko et al., 1995).

The silicate glasses and carbonate globules from the Mangaia melt inclusions have a large range of trace element compositions (Figure 4, Table 1 and Appendix). The silicate glasses range to very high $\mathrm{Sr}$ and $\mathrm{Ba}$ contents (up to 1.4 and $0.8 \mathrm{wt} \%$ respectively). Also, they have variable REE concentrations, with $\mathrm{La}$ and $\mathrm{Yb}$ ranging from 10 to 300 and 0.3 to 20 times primitive mantle respectively. Fractionation of the REEs is also large with $(\mathrm{La} / \mathrm{Yb})_{\mathrm{PM}}$ ratios reaching values up to 90 , as compared to most whole rocks which typically have ratios of $\approx 10$ (Hauri and Hart, 1997). Moreover, we found that several melt inclusions have a large fractionation between $\mathrm{Zr}$ and $\mathrm{Hf}$, with $\mathrm{Zr} / \mathrm{Hf}$ ratios ranging up to 100 , similar to the $\mathrm{Zr} / \mathrm{Hf}$ ratios reported for Mangaia and Tubuaii lavas (Dupuy et al., 1992). 
Only two carbonate globules were analyzed for trace element contents (Table 1). From 140 melt inclusions, we found only two carbonate globule large enough to allow us to get a representative composition of the carbonate without any influence from the surrounding silicate glass. The high trace element contents of the carbonates globules, specially the high rare earth elements, compared to those of carbonates produced during secondary (hydrothermal) processes, suggests that the carbonates have had a magmatic origin. However the trace element content (i.e., $\mathrm{La}<60 \mathrm{ppm}$ ) and the $(\mathrm{La} / \mathrm{Yb})_{\mathrm{PM}}$ ratios in the carbonate globules (5 to 35 ) are generally lower than those reported for carbonatitic melts (Nelson et al., 1988). This is also true for their alkali contents, where the $\mathrm{Na}_{2} \mathrm{O}$ and $\mathrm{K}_{2} \mathrm{O}$ in the carbonate globules are low compared to those of carbonatitic melts experimentally produced by an immiscibility process (Lee and Wyllie, 1998). Thus, although the texture suggests that the carbonate is formed by immiscibility process, the compositions of the carbonates are not consistent with this hypothesis. The same apparent contradiction between textures and carbonate compositions was also described for carbonate-silicate melt pockets in carbonated peridotitic xenoliths from Spitsbergen (Ionov et al., 1993; 1996).

We also recovered olivine (Fo 86)-hosted melt inclusions from a primitive basalt from Tahaa (TAA-B-26). These melt inclusions are ellipsoidal in shape and range from 10 to $100 \mu \mathrm{m}$ in diameter. In contrast to the Mangaia melt inclusions, the Tahaa melt inclusions are much simpler. Silica-alumina-alkali-rich glass (phonolitic) records only insitu fractional crystallization of clinopyroxene, Cr-spinel, ilmenite- and plagioclase, and segregation of sulfide globules (Table 1 and Appendix). Compared to the Mangaia inclusions the Tahaa melt inclusions have a smaller range in REE concentrations (La and $\mathrm{Yb}$ ranging from 50 to 250 and 3 to 10 times primitive mantle, respectively) and smaller $\mathrm{REE}$ fractionation ( $\mathrm{La} / \mathrm{Yb}_{\mathrm{PM}}$ ranges from 9 to 33; Table 1 and Appendix).

The olivines (Fo 80) and two spinel-hosted melt inclusions recovered from Pitcairn sample (PIT 1; Eiler et al., 1995) have not yet been analyzed for major or trace element composition.

The petrography, major and trace element compositions of two mantle xenoliths from Tubuaii (TBA 1-9 and TBA 4-11), have been described in previous work (Hauri et al., 1993). TBA 1-9 is a wherlite consisting of primary olivine (Fo 90) and minor orthopyroxene. $40 \%$ by volume of the xenolith consists of melt pockets made of 
clinopyroxene + silica-alumina-alkali-rich glass (phonolitic) + spinel \pm euhedral apatite. These melt pockets have rectangular habits, resembling pseudomorphs after a single phase. Hauri et al., (1993) reconstructed the compositions of the melt pockets; they suggested that the composition resembles that of subcalcic pyroxene ( \pm apatite). TBA 4-11 is a wherlitic dunite consistent of olivine (Fo 84-90), chromite and apatite. This xenolith also has silicarich glass forming up to $10 \%$ of the total volume of the sample.

\subsubsection{Pb isotopes}

SIMS analyses of $\mathrm{Pb}$ isotope ratios $\left({ }^{207} \mathrm{~Pb} /{ }^{206} \mathrm{~Pb}\right.$ and $\left.{ }^{208} \mathrm{~Pb} /{ }^{206} \mathrm{~Pb}\right)$ of the melt inclusion populations from Mangaia, Tahaa and Pitcairn islands, and of clinopyroxene and melt pockets from Tubuaii xenoliths, are reported in Table 2 . The $\mathrm{Pb}$ isotopic ratios of melt inclusions from the two Mangaia basalts show large and systematic variations that overlap with the $\mathrm{Pb}$ isotope compositions of whole rocks from the entire Cook-Austral Islands chain between Mangaia island and Macdonald seamount (Mangaia, Tubuaii, Rimatara, Rurutu, Raivavae, Rapa, Morotiri and Macdonald) (Figure 5 and 6). In the Mangaia melt inclusions, ${ }^{20} 7 \mathrm{~Pb} /{ }^{206} \mathrm{~Pb}$ varies from 0.706 to 0.815 , and ${ }^{208} \mathrm{~Pb} /{ }^{206} \mathrm{~Pb}$ ratios range from 1.840 to 2.02 . These isotopic variations in the Mangaia melt inclusions are much larger than those observed for Mangaia whole rock lavas (0.726 to 0.735 and 1.869 to 1.883 respectively), and cover $50 \%$ of the entire range defined by the world-wide population of oceanic island basalts (OIB, Figure 5). In a similar way, the range in $\mathrm{Pb}$ isotopes of the Tahaa melt inclusions is larger than that observed for Tahaa whole rock lavas, and overlaps with the $\mathrm{Pb}$ isotopic composition of whole rock lavas from the entire Society Island chain (Cyana, Mehetia, Moua Piha, Rocard, Tahaa, Tahiti, and Teahitia) (Figure 7). For Tahaa melt inclusions, ${ }^{207} \mathrm{~Pb} /{ }^{206} \mathrm{~Pb}$ varies from 0.809 to 0.824 , and ${ }^{208} \mathrm{~Pb} /{ }^{206} \mathrm{~Pb}$ ranges from 2.009 to 2.048 , while the $\mathrm{Pb}$ isotopes for Tahaa whole rock lavas vary from 0.811 to 0.816 and from 2.027 to 2.032 respectively. The $\mathrm{Pb}$ isotopic composition of Pitcairn melt inclusions have a similar range in ${ }^{207} \mathrm{~Pb} /{ }^{206} \mathrm{~Pb}$ ratios, but a larger range in ${ }^{208} \mathrm{~Pb} /{ }^{206} \mathrm{~Pb}$ ratios than those reported for Pitcairn whole rock lavas (Figure 7). Thus, for Pitcairn melt inclusions, ${ }^{207} \mathrm{~Pb} /{ }^{206} \mathrm{~Pb}$ and ${ }^{208} \mathrm{~Pb} /{ }^{206} \mathrm{~Pb}$ vary from 0.841 to 0.875 and from 2.054 to 2.196 , meanwhile the whole rock lavas range from 0.838 to 0.878 and from 2.107 to 2.210 respectively. Finally, the $\mathrm{Pb}$ isotopic composition of the melt pockets and clinopyroxene from the Tubuaii xenoliths reproduced exactly the $\mathrm{Pb}$ isotopic measurements reported by Hauri et al., (1993) (Figure 7). Thus, the range in ${ }^{207} \mathrm{~Pb} /{ }^{206} \mathrm{~Pb}(0.739-0.751)$ and 
${ }^{208} \mathrm{~Pb} /{ }^{206} \mathrm{~Pb}(1.905-1.921)$ obtained by TIMS compare very well with the variation in $\mathrm{Pb}$ isotopes $(0.746-0.750$ and $1.918-1.925)$ obtained in this work by SIMS.

For samples with high $\mathrm{Pb}$ concentrations (measured ${ }^{208} \mathrm{~Pb}$ counts rates higher than $2,000 \mathrm{cps} ; \approx 5 \mathrm{ppm} \mathrm{Pb}$ content), we measured ${ }^{206} \mathrm{~Pb} /{ }^{204} \mathrm{~Pb}$ ratios on subsets of melt inclusions from Mangaia, Tahaa and melt pockets from Tubuaii xenoliths (Table 2). The range in ${ }^{206} \mathrm{~Pb} /{ }^{204} \mathrm{~Pb}$ ratios for Mangaia and Tahaa melt inclusions is larger than that for whole rock lavas, while the ${ }^{206} \mathrm{~Pb} /{ }^{204} \mathrm{~Pb}$ ratios measured on Tubuaii melt pockets by SIMS reproduce those measured by TIMS. Thus, the ${ }^{206} \mathrm{~Pb} /{ }^{204} \mathrm{~Pb}$ ratios measured by SIMS substantiate the variation observed in ${ }^{207} \mathrm{~Pb} /{ }^{206} \mathrm{~Pb}$ and ${ }^{208} \mathrm{~Pb} /{ }^{206} \mathrm{~Pb}$ ratios. SIMS ${ }^{206} \mathrm{~Pb} /{ }^{204} \mathrm{~Pb}$ ratios measured in melt inclusions and melt pockets range from 22.01 to 19.63 in Mangaia, from 18.94 to 19.73 in Tahaa, and from 21.07 to 21.16 in Tubuaii. These variation in ${ }^{206} \mathrm{~Pb} /{ }^{204} \mathrm{~Pb}$ ratios in melt inclusions are very different from the ranges measured by TIMS on Mangaia and Tahaa whole rock lavas (from 21.480 to 21.932, and from 19.16 to 19.29 respectively), and similar to those measured in melt pockets of the Tubuaii xenolith (from 20.97 to 21.31 ), reproducing the variations observed in ${ }^{207} \mathrm{~Pb} /{ }^{206} \mathrm{~Pb}$ and ${ }^{208} \mathrm{~Pb} /{ }^{206} \mathrm{~Pb}$ ratios (Hart et al., 1992; Hauri and Hart, 1993; Hauri et al., 1993; Woodhead, 1996).

\subsection{Discussion}

\subsubsection{Petrography, major and trace element composition of the melt inclusions}

The compositional zoning observed in daughter and host minerals near the inclusion is explained simply by post-entrapment fractional crystallization of the melt inclusion. Sometimes, euhedral phases inside the melt inclusions are too large to be daughter phases crystallized from the trapped melt. These are crystals trapped along with the melt at the same time, by the olivine or clinopyroxene host. Common trapped phases are $\mathrm{Cr}$-spinel or clinopyroxene. They are strongly zoned, with the core composition similar to that of groundmas Cr-Spinel and the clinopyroxene phenocrysts respectively; meanwhile, the margins become more enriched in Ti produced during post-entrapment crystallization of the melt inclusion (see Appendix). As a cautionary note, trapped crystals are an important reason why melt inclusions must be studied first before they are homogenized.

Previous works suggested the presence of a carbonated mantle source for the magmas from the Cook-Austral islands, largely based on indirect evidence : 
1) the compositional and mineralogical characteristics of peridotitic xenoliths from Tubuai island (Hauri et al., 1993);

2) the observed supra-chondritic $\mathrm{Zr} / \mathrm{Hf}$ ratios in basaltic lavas from Tubuai and Mangaia islands (Dupuy et al., 1992); and

3) the similar geochemical and isotopic characteristics between carbonatitic magmas and some oceanic island basalts (Nelson et al., 1988). However, direct evidence for primary carbonate melts in peridotite xenoliths or in basaltic rocks has never been reported for the Cook-Austral chain.

The association of the carbonate globules with $\mathrm{Ca}$ or $\mathrm{Mg}$ volatile-rich silicate glasses (up to $15 \%$ volatiles), and with silica-alumina-alkali rich glasses in Mangaia melt inclusions, are essentially the same as those described for carbonate-silicate melt pockets in carbonated peridotitic xenoliths such as Spitsbergen, Canary Island, Tubuaii, Kerguelen and Northern Tanzania (Ionov et al., 1993; 1996; ; Kogarko et al., 1995; Hauri et al., 1993; Schiano et al., 1994; Rudnick et al., 1993; among others). The observed mineral associations, mineral and glass compositions, and the ocelli textures between carbonate globules and silicate glasses in the melt inclusions from both Mangaia lavas provide the first direct evidence for a carbonated mantle source for HIMU basalts (Table 1 and Appendix).

As mentioned previously, the ocelli texture between carbonate globules and silicate glass, and the presence of droplets of silicate glass in carbonate spherules, bounded by sharp, curved menisci (Figure 3a) has been considered as clear evidence of liquid immiscibility (Ionov et al., 1993; 1996; ; Kogarko et al., 1995). However, the REE content and the $(\mathrm{La} / \mathrm{Yb})_{\mathrm{PM}}$ ratios in carbonate globules from the melt inclusions or melt pockets in peridotites, are generally lower than those reported for carbonatitic rocks that have been formed by immiscibility processes (Nelson, et al., 1988). To evaluate whether liquid immiscibility is the process responsible for the formation of the carbonate globules in the Mangaia melt inclusions, we used the phase diagram for the pseudo-quaternary system $\mathrm{CaO}-\left(\mathrm{MgO}+\mathrm{FeO}^{*}\right)-\left(\mathrm{Na}_{2} \mathrm{O}+\mathrm{K}_{2} \mathrm{O}\right)-\left(\mathrm{SiO}_{2}+\mathrm{Al}_{2} \mathrm{O}_{3}+\mathrm{TiO}_{2}\right)$ with $\mathrm{CO}_{2}$ at 1.0 and $2.5 \mathrm{GPa}$ pressure (Lee and Wyllie, 1998). This diagram provides a petrogenetic framework for magmatic processes occurring within the mantle and deep crust (Figure $8 \mathrm{a}$ and $\mathrm{b}$ ). In Figure 8, the composition of the proposed immiscible carbonate globules and associated silicate glasses are compared with the $1.0 \mathrm{GPa}$ and $2.5 \mathrm{GPa}$ phase diagram. Moreover in 
both Figures, $8 \mathrm{a}$ and $\mathrm{b}$, we have also plotted the composition of carbonate globules and silicate glasses from Spitsbergen xenoliths (Ionov et al. 1993). Carbonate globules and silicate glasses from both, Mangaia melt inclusions and melt pockets from Spitsbergen xenoliths, have similar compositions, plotting well outside the miscibility gap. Therefore, the phase relations shown in Figure 8 indicates that none of the Mangaia silicate glass and carbonate globule compositions from the melt inclusions represent equilibrium immiscible liquids.

Carbonate globules and silicate glasses are too far removed from the miscibility gap, well inside the forbidden volumes of the primary silicate and carbonate liquidus respectively (Lee and Wyllie, 1998). Thus, although the ocelli texture is suggestive of immiscibility, the major and trace element composition of the carbonate globules and silicate glasses do not support this hypothesis. Lee et al. (1994) and Lee and Wyllie (1996 and 1997) were able to reconcile the textural with the chemical evidences. They demonstrated that, through a wide range in compositions, rounded calcites coexisting with silicate or carbonate liquids were in fact rounded single crystal phases. Therefore, some of the round calcites can be explained as crystal phases crystallizing from a silicate or silicatecarbonate melt.

Ionov et al., (1996) suggested that dolomite and magnesian calcite represent primary melts and that amorphous magnesite-ankerite phases are formed as a result of melting and breakdown of primary carbonate minerals in carbonate-bearing mantle xenoliths from Spitsbergen. Moreover, they consider that the Mg-rich silicate glass reported for Spitsbergen xenoliths (Amudsen, 1987 and Ionov et al., 1993) may have been formed by decompression-induced dissolution of olivine into a preexisting cabonate-rich melt. Due to the similarity in composition between the melt pockets in the Spitsbergen xenoliths and the Mangaia melt inclusions, we will follow the Ionov et al. (1996), and Lee and Wyllie (1998) interpretation. Thus, our results would suggest that Mangaia silicate glasses and carbonate globules record a complex history of crystal fractionation, and probably in some cases (Mg-rich volatile bearing glasses), decompression-induced dissolution or reaction of the olivine host in contact with the volatile-rich melt inclusions. Moreover, the round carbonate globules observed in the Mangaia melt inclusions are probably a phase crystallized from a primitive $\mathrm{CO}_{2}$-rich magma at pressures lower than 2.5 GPa. 
Tahaa melt inclusions have glasses with simple compositions, recording fractional crystallization of Ti-augite, ilmenite, $\mathrm{Cr}$-spinel and plagioclase and segregation of sulfide globules (Table 1 and Appendix).

The origin of the silica-alumina-alkali rich (phonolitic) glasses in mantle xenoliths and in Tahaa and Mangaia melt inclusions is controversial and several hypotheses have been proposed:

1) silicate-carbonate melt immiscibility (Ionov et al., 1993; 1996; Kogarko et al., 1995).

2) break-down of a crystal phase such as clinpyroxene during decompression-induced melting (Hauri et al., 1993)

3) low extent of partial melting of an amphibole peridotite (Schiano and Colocciatti, 1994)

4) partial melting of an eclogite created through subduction of oceanic crust, (Schiano et al., 1995)

5) extreme fractional crystallization of a small volume of melt percolating through the lithosphere (Schiano and Colocciatti, 1994)

The silica-rich glasses in the melt inclusions from Tahaa and Mangaia suggest that they are not necessarily related to silicate-carbonate immiscibility because:

a) the Tahaa melt inclusions do not have carbonate globules; and

b) the major element composition of the carbonate globules and silicate melts are not consistent with immiscibility.

Most of the melt inclusions are rounded and do not have sharp rectangular borders resembling pseudomorphs of a crystal phase (clinopyroxene) undergoing decompression melting. Therefore, we discard the hypothesis of a break-down of crystal phases by decompression-induced melting as the process responsible for the formation of the silicarich glass. The silica-rich glasses are usually associated with many different daughter crystals (Table 1 and Appendix). Thus, when the composition of the melt inclusion or melt pocket is averaged over the whole inclusion, the composition is no longer phonolitic, but basaltic [see Appendix and compare the phonolitic compositions obtained by analyses done 
with small beams ( 5 to $10 \mu$ ) with the basaltic ones obtained with large beams ( 20 to $30 \mu$ ) for the same melt inclusions]. Thus, the melt inclusions cannot be low extent melts from eclogites or amphibole peridotites because they do not have an averaged composition similar to that of the silica-alumina-alkali rich glasses. Therefore, the high silica glasses seem to be simple residual melts after post-entrapment fractional crystallization of the melt inclusions or after extensive fractional crystallization during melt percolation in the lithosphere prior to entrapment.

In the Mangaia and Tahaa melt inclusions, some of the trace element variability is likely a result of partial melting processes, but much of the trace element signal is complicated by extensive in-situ fractional crystallization. In the Mangaia melt inclusions, additional complexity is added by silicate-carbonate fractionation and probably by decompression-induced dissolution or reaction of crystal phases in the volatile-rich melt inclusions. Thus, while the presence of carbonate melts shows that the sub-Mangaia mantle is at least locally carbon-rich, the trace element data indicate little else about the Mangaia and Tahaa mantle source compositions, and it is difficult to deduce information regarding mantle source variability from the trace element compositions observed in these melt inclusions. Thus, the distinct mantle components beneath Mangaia and Tahaa are best resolved by measuring radiogenic isotopes on individual melt inclusions.

\subsubsection{Pb isotopes}

Figure 5, 6 and 7 show the large and systematic variations in $\mathrm{Pb}$ isotopic composition $\left({ }^{207} \mathrm{~Pb} /{ }^{206} \mathrm{~Pb}\right.$ and $\left.{ }^{208} \mathrm{~Pb} /{ }^{206} \mathrm{~Pb}\right)$ of melt inclusions from Mangaia, Tahaa and Pitcairn basalts. These variations are larger than the range in $\mathrm{Pb}$ isotopes reported for whole rock lavas for each island and overlap with the entire isotopic variation reported for each one of the islands chains: Cook-Austral chain, Society islands and Pitcairn island and seamounts.

The $\mathrm{Pb}$ isotope data for Mangaia, Tahaa and Pitcairn forms quasi-linear arrays that can be described by simple mixing of two end-members. For Mangaia, one component (end-member) is rich in radiogenic $\mathrm{Pb}$ and is identical to the HIMU component observed in erupted Mangaia lavas (Hauri and Hart, 1993; Woodhead, 1996). The $\mathrm{Pb}$ isotopic compositions of sulfide- and carbonate-bearing melt inclusions invariably reflect this endmember HIMU (Table 2, Figure 6). Whether the carbonation is responsible for the HIMU signature or merely accompanies it is still an unresolved issue. The second component is 
defined by a less-radiogenic $\mathrm{Pb}$ composition (hereafter called the "less radiogenic component"). The exact identity of this component is difficult to establish, partly because of the analytical errors involved, as can be seen from Figure 6 and 7 . It could be either the enriched mantle component observed in erupted lavas from other islands in the CookAustral chain, such as Macdonald seamount (Nakamura and Tatsumoto 1988; Chauvel et al., 1992; Chauvel et al., 1997; Hemond et al., 1994) or a depleted upper mantle component, such as the Pacific MORB (Zindler and Hart, 1986 and references therein). For the Tahaa melt inclusions, the $\mathrm{Pb}$ isotopic composition can also be explained by mixing between a component represented by the EMII mantle end-member, and a second component that is identical to the less radiogenic component observed in the Mangaia melt inclusions. The $\mathrm{Pb}$ isotopic compositions of sulfide from Tahaa melt inclusions are endmember EMII (Figure 7). The Pb data for the Pitcairn sample can be explained by a similar mixing trend between the EM I mantle end-member, and probably the same less-radiogenic component as in Mangaia and Tahaa (Figure 7). The less radiogenic component present in melt inclusions from the three end-member oceanic island basalts is similar to ubiquitous mantle components such as "FOZO" (Hart et al., 1992) or C (Hannan and Graham, 1996), although the geologic significance of this similarity is not clear at this point.

The $\mathrm{Pb}$ isotopic compositions in melt inclusions from sample MAG-B-47 (Mangaia) correlate negatively with the Cr content of daughter clinopyroxenes (Figure 9). The melt inclusions from Tahaa plot at one extreme of this correlation, corresponding to the less radiogenic component, and the lowest $\mathrm{Cr}$ content of daughter clinopyroxenes (Figure 9). The $\mathrm{Cr}$ variation in the daughter clinopyroxenes could be considered to reflect a different extent of in-situ fractionation resulting from olivine and $\mathrm{Cr}$-spinel crystallization in the melt inclusion. However, the correlation between the $\mathrm{Pb}$ isotopes and the $\mathrm{Cr}$ content in the clinopyroxene cannot be explained by a simple crystal fractionation model and instead requires a process that couples the change of $\mathrm{Cr}$ in clinopyroxene with the $\mathrm{Pb}$ isotope composition of the melt inclusions. This negative correlation suggests that the melt corresponding to the less radiogenic component may have suffered differentiation before its entrapment, or represents a source material present in the mantle which is already differentiated (eclogite?). We can explain this correlation in several ways:

1) A HIMU melt underwent coupled assimilation and fractional crystallization processes (AFC); as the primitive HIMU melt differentiates, it assimilates lithospheric material (lower oceanic crust?) with a less radiogenic $\mathrm{Pb}$ isotope composition. 
2) Mixing of two melts: one, a primitive HIMU melt and one melt having a less radiogenic signature that has undergone crystal fractionation (low $\mathrm{Cr}$ ) within the oceanic lithosphere prior to the mixing.

3) The less radiogenic component could also be a melt originating from a previously differentiated source. For example, partial melts of eclogites produced during recycling of the oceanic crust.

4) It is entirely possible that, during basalt-lithospheric interaction, many of the olivines observed in the Mangaia samples could be xenocrysts coming from the lithosphere, carrying inclusions with compositions not consistent with the host lava. MAGB-47 olivines have a range in Fo content from 86 to 89 . Therefore, if some of the olivines come from the lithosphere (Fo 91-92), the lower range in Fo content of the olivine phenocrysts in Mangaia lavas may indicate a tendency for the xenocrysts to equilibrate with the host lava.

To test whether there is any indication that the less radiogenic $\mathrm{Pb}$ component is situated in the lithosphere of the Cook-Austral islands, we analyzed the melt pockets and clinopyroxene from two peridotitic xenoliths from Tubuaii (Hauri et al., 1993). From seven analyses (six on melt pockets and one on clinopyroxene), none gave an isotopic composition similar to the unradiogenic component, and all of the isotopic compositions measured are similar to those of Tubuaii whole rock lavas.

The SIMS $\mathrm{Pb}$ data, and the range of $\partial^{18} \mathrm{O}$ (from 4.98 to 5.03 for Mangaia, 5.71 for Tahaa and 5.22 for Pitcairn) previously measured in olivine phenocrysts from the same samples (Eiler et al., 1995; 1997), suggests that the less radiogenic component could be derived from either the mantle or oceanic lithosphere.

There exists no evidence from data on erupted Mangaia lavas for the second, less radiogenic, component that we observe in the melt inclusions. This lack of evidence in the erupted lavas for the less radiogenic $\mathrm{Pb}$ isotopic compositions suggests that the proportion of this component in the erupted lavas must be small. In the case of Pitcairn, we see a trend toward a less radiogenic component in the isotopic composition of the whole rock lavas (Figure 5) although it is not as extreme as the range shown by the melt inclusions. In contrast to Mangaia and Pitcairn, the $\mathrm{Pb}$ isotopic composition of whole rock lavas from Tahaa is within errors the same as the less radiogenic component observed in the melt 
inclusions, suggesting a high proportion of this end-member and a dilution of the EMII end member in the Society chain. It is apparent from the $\mathrm{Pb}$ isotope data that shallow-level storage and mixing of distinct magma batches resulted in homogenization and dilution of the less radiogenic component within Mangaia and Pitcairn magmas, and dilution of the EMII component in the Tahaa lavas, prior to eruption. The melt inclusions are thus valuable samples for revealing magmatic diversity within the volcanic plumbing system beneath Mangaia, Pitcairn and Tahaa, and for providing information that is invisible in the erupted lavas. Moreover, we did not find melt inclusions with more extreme end-member isotopic compositions than those defined by the whole rocks. Therefore, the end-member $\mathrm{Pb}$ isotopic compositions remain as previously defined (Zindler and Hart, 1986; Hart et al., 1992).

In synthesis, the broad linear trend in ${ }^{207} \mathrm{~Pb} /{ }^{206} \mathrm{~Pb}-{ }^{208} \mathrm{~Pb} /{ }^{206} \mathrm{~Pb}$ space produced by the melt inclusions from Mangaia, Tahaa and the Pitcairn samples reproduces the entire trend defined by the Austral and Society chains and the Pitcairn island and seamount groups. The inclusions preserve a record of melt composition of far greater isotopic diversity than that sampled in whole rock basalts. The results suggest that the entire CookAustral chain, the Pitcairn island group and the Society island array can be explained by mixing of the HIMU, EMI and EMII end-members with a common component (less radiogenic component), respectively. The HIMU $\mathrm{Pb}$ isotopic composition measured for the carbonated globules, in conjunction with their textures and compositions, provide direct evidence for a carbonated mantle source beneath the Austral Islands.

\subsection{Conclusions}

The major and trace element composition of carbonate globules and silicate glasses from melt inclusions from phenocrysts from Mangaia basalts are not consistent with an immiscibility processes, but suggest simple crystallization of carbonates from a $\mathrm{CO}_{2}$-rich silicate melt. Moreover, the silica-alumina-alkali-rich glasses in melt inclusions from Mangaia and Tahaa lavas, and in melt pockets in mantle xenoliths, seem to be the result of post-entrapment crystallization of the melt inclusions or extensive fractional crystallization during melt percolation in the lithosphere.

The observed HIMU Pb isotopic composition of carbonate globules, their ocelli texture, and mineral associations, and the mineral and glass compositions in melt inclusions 
from two Mangaia basalts provide the first direct evidence for a carbonated mantle source for HIMU basalts.

The melt inclusion $\mathrm{Pb}$ isotope data for Mangaia, Tahaa and Pitcairn forms quasilinear arrays that can be described by simple binary mixing between the HIMU, EMI and EMII end-member compositions and an unradiogenic component common to all three isotopic arrays. Therefore, the geochemical variation in trace and major elements from melt inclusions does not always represent variable melting processes of a single mantle source, but clearly reflect geochemical source heterogeneities as well.

The negative correlation between the $\mathrm{Cr}$ content in daughter clinopyroxene and the $\mathrm{Pb}$ isotope composition of the melt inclusions from Mangaia suggests that the melt corresponding to the less radiogenic component may have suffered differentiation before its entrapment, or represents a source material in the mantle that has already been differentiated (eclogite?). 


\subsection{References}

Albee A. L. and Ray L., Correction factors for electron probe microanalysis of silicates, oxides, carbonates, phosphates and sulfates. Anal. Chem. 42: 1408-1414, 1970.

Amundsen H. E. F., Evidence for liquid immiscibility in the upper mantle. Nature 327: 692-695, 1987.

Bence A. E. and Albee A. L., Empirical correction factors for the electron microanalysis of silicates and oxides. J. Geol. 76: 382-403, 1968.

Chauvel C., Hofmann A. W. and Vidal P. , HIMU-EM: the french polynesian connection. Earth Planet. Sci. Lett. 110, 99-119 1992.

Chauvel C., McDonough W., Guille G., Maury R. and Duncan R., Contrasting old and young volcanism in Rurutu island, Austral chain. Chem. Geol. 139, 125-143 1997.

Dupuy C., Liotard J. M. and Dostal J., Zr/Hf fractionation in intraplate basaltic rocks: carbonate metasomatism in the mantle source Geochim. Cosmochim. Acta 56, 2417$2423,1992$.

Eiler J. M., Farley K. A., Valley J. W., Hauri E. H., Craig H., Hart S. R. and Stolper E. M. , Oxygen isotope variations in the ocean island basalt phenocrysts. Geochim. Cosmochim. Acta 61, (11) 2281-2293, 1997.

Eiler J. M., Farley K. A., Valley J. W., Stolper E. M., Hauri E. H. and Craig H., Oxygen isotope evidence against bulk recycled sediment in the mantle sources of Pitcairn island lavas. Nature 377:138-141, 1995.

Garcia M. O., Foss D. J. P., West H. B., and J. J. Mahoney, Geochemical and isotopic evolution of Loihi volcano, Hawaii. J. Petrology, 36, 1647-1674, 1995.

Gurenko A. A. and Chaussidon M., Enriched and depleted primitive melts included in olivine from Icelandic tholeiites: origin by continuous melting of a single mantle column. Geochim Cosmochim Acta 59, 14, 2905-2917, 1995.

Hannan B. B. and Graham D. W., Lead and Helium isotope evidence from oceanic basalts for a common deep source of mantle plumes. Science 272, 991-995, 1996.

Hart S. R., Hauri E. H., Oschmann L. A. and Whitehead J. A. , Mantle plumes and entrainment: isotopic evidence. Science 256, 517-520, 1992.

Hauri E. H. and Hart S. R., Re-Os isotope systematics of HIMU and EMII oceanic island basalts from the south Pacific ocean. Earth Planet. Sci. Lett. 114, 353-371, 1993.

Hauri E. H. and Hart S. R., Rhenium abundances and systematics in oceanic basalts. Chem. Geology 139, (1-4), 185-205, 1997.

Hauri E. H., Shimizu N. , Dieu J. and Hart S. R., Evidence for hotspot-related carbonatite metasomatism in the oceanic upper mantle. Nature 365, 221-227, 1993. 
Hauri E. H., Zhang J., Herzberg C. and Fei Y., Trace element partitioning at high pressures: new ion probe results and implications for differentiation of a terrestrial magma ocean. (abst), J. Conf. Abst. 1, p. 241, 1996.

Hemond C., Devey C. W. and C. Chauvel, Source compositions and melting processes in the Society and Austral plumes (south Pacific ocean): element and isotope ( $\mathrm{Sr}, \mathrm{Nd}, \mathrm{Pb}, \mathrm{Th}$ ) geochemistry. Chem. Geol. 115, 7-45, 1994.

Hofmann A. W., Mantle geochemistry: the message from oceanic volcanism. Nature 385: 219-229, 1997.

Ionov D., O'Reilly S. Y, Genshaft Y. and M. Kopylova, Carbonate-bearing mantle peridotite xenoliths from Spitsbergen: phase relationships, mineral compositions and traceelement residence. Contri. Miner. Petrol. 125, 375 - 392, 1996.

Ionov D., Dupuy C., O'Reilly S. Y., Kopylova M. G. and Genshaft Y. S., Carbonated peridotitic xenoliths from Spitsbergen: Implications for trace element signature of mantle carbonate metasomatism. Earth Planet. Sci. Lett. 119, 283-297, 1993.

Kamenetsky V. and Clocchiatti R., Primitive magmatism of Mt. Etna: insights from mineralogy and melt inclusions. Earth Planet. Sci. Lett. 142, 553-572, 1996.

Kamenetsky V., Methology for the study of melt inclusions in Cr-spinel, and implications for parental melts of MORB from FAMOUS area. Earth Planet. Sci. Lett. 142, 477-484, 1996.

Kogarko L. N., Henderson C. M. B. and Pacheco H., Primary Ca-rich carbonatite magma and carbonate-silicate-sulphide liquid immiscibility in the upper mantle. Contrib. Min. Petrol. 121, 267-274, 1995.

Lassiter J. C., Hauri E. H. and Barsczus H. G., (abs), Influence of the Austral fracture zone on the composition of lavas from Raivavae, Austral Islands: Evidence for crustal assimilation during magma ascent and evolution. Eos Trans., AGU 79 (17), spring meeting suppl., S378, 1998.

Layne G. D. and Shimizu N., Measurement of lead isotope ratios in common silicate and sulfide phases using the Cameca IMS 1270 ion microprobe, in G. Gillen, R. Lareau, J . Bennett and F Stevie (eds.). Secondary ion mass spectrometry SIMS XI, John Wiley \& son. p 63-65, 1997.

Lee W.-j. and Wyllie P. J. , Petrogenesis of carbonatite magmas from mantle to crust constrained by the system $\mathrm{CaO}-\left(\mathrm{MgO}+\mathrm{FeO}^{*}\right)-\left(\mathrm{Na}_{2} \mathrm{O}+\mathrm{K}_{2} \mathrm{O}\right)-\left(\mathrm{SiO}_{2}+\mathrm{Al}_{2} \mathrm{O}_{3}+\mathrm{TiO}_{2}\right)-\mathrm{CO}_{2} . \mathrm{J}$. Petrology 39, (3), 495-517, 1998.

Lee W.-j., Wyllie P. J. and Rossman G. R., CO2-rich glass, round calcite crystals and no liquid immiscibility in the system $\mathrm{CaO}-\mathrm{SiO}_{2}-\mathrm{CO}_{2}$ at $2.5 \mathrm{GPa}$. Am. Mineral. 79: 1135-1144, 1994.

Lee W.-j. and Wyllie P. J. Liquid immiscibility in the join $\mathrm{NaAlSi}_{3} \mathrm{O}_{8}-\mathrm{CaCO}_{3}$ to $2.5 \mathrm{GPa}$ and the origin of calciocarbonatite magmas. J. Petrology 37: 1125-1152, 1996. 
Lee W.-j. and Wyllie P. J. Liquid immiscibility between nephelinite and carbonatite from 2.5 to $1.0 \mathrm{GPa}$ compared with mantle melt compositions. Contrib. Min. Petrol. 127: 1-16, 1997.

Nakamura $\mathrm{Y}$. and Tatsumoto $\mathrm{M}$. , $\mathrm{Pb}$, $\mathrm{Nd}$ and $\mathrm{Sr}$ isotopic evidence for multicomponent source for rocks of Cook-Austral Island and heterogeneities of mantle plumes. Geochim. Cosmochim. Acta 52, 2909-2924, 1988.

Nielsen R. L., Estimating the volumetric proportions of parent magmas using melt inclusions. Eos Trans., AGU 76, spring meeting suppl., S266, 1995.

1995 ,

Nelson D. R., Chivas A. R., Chappell B. W. and McCulloch M. T., Geochemical and isotopic systematics in carbonatites and implications for the evolution of ocean-island source. Geochim. Cosmochim. Acta 52,1-17, 1988.

1988

Rudnick R. L., McDonough W.F. and Chappell B. W., Carbonatite metasomatism in the northern Tanzanian mantle: petrographic and geochemical characteristics. Earth Planet. Sci. Lett. 114, 463-475, 1993.

Schiano P. and Clocchiatti R., Worldwide occurrence of silica-rich melts in sub-continental and sub-oceanic mantle minerals. Nature 368: 621-624, 1994.

Schiano P., Clocchiatti R., Shimizu N., Weis D. and Mattielli N., Cogenetic silica-rich and carbonate-rich melts trapped in mantle minerals in Kerguelen ultramafic xenoliths: Implications for metasomatism in the oceanic upper mantle. Earth Planet. Sci. Lett. 123, 167-178, 1994;

Schiano P., Clocchiatti R., Shimizu N., Maury R. C., Jochum K. P. And Hofmann A. W., Hydrous, silica-rich melts in the sub-arc mantle and their relationship with erupted arc lavas. Nature 377: 595-600, 1995.

Shimizu N. and Hart S. R., Application of the ion microprobe to geochemistry and cosmochemistry. Ann. Rev. Earth Planet. Sci. 10, 483-526, 1982.

Sobolev A. V. and Shimizu N., Ultra-depleted primary melt included in an olivine from the mid-Atlantic ridge. Nature , 363, 151-154, 1993.

Sobolev A. V., Gurenko A. A. and Shimizu N., Ultra-depleted melts from Iceland: data from melt inclusion studies. Mineral. Mag. 58A: 860-861, 1994a.

Sobolev A. V., Casey, J. F., Shimizu N. and Perfit M., Ultra-depleted melts included in olivine from the Siqueiros transform fault: Evidence for near-fractional melting, mixing and contamination leading to formation of melts parental to MORB. Unpublished manuscript, $1994 b$.

Sobolev A. V. and Danyushevsky L. V., Petrology and geochemistry of boninites from the north termination of the Tonga trench: Constraints on the generation conditions of primary high-Ca boninite magmas. J. Petrol. 35: 1183-1213, 1994. 
Sun S.-s. and McDonough W. F., Chemical and isotopic systematics of oceanic basalts: implications for mantle composition and processes, in A.D. Saunders and M.J. Norry (eds.), Magmatism in the oceanic basins. Geological Society Special Publication No 42 313-345, 1989.

Woodhead J. D., Extreme HIMU in an oceanic setting: the geochemistry of Mangaia island (Polynesia), and temporal evolution of the Cook-Austral hotspot. J. Volcanology and Geothermal Research 72, 1-19, 1996.

Zindler A. and Hart S. R., Chemical geodynamics.. Ann. Rev. Earth Planet. Sci. 14, 493$571,1986$.

NOTE: This chapter is based on an already published work: Saal A. E., Hart S. R., Shimizu N. Hauri E. H. and Layne G. D., Pb isotopic variability in melt inclusions from oceanic island basalts, Polynesia. Science 282, 1481-1484 (1998). 


\subsection{Table Caption}

Table 1: Major and trace element compositions for representative glasses, carbonates, sulfides and minerals from melt inclusions and their mineral hosts. Major elements (in wt\%) were determined on the Jeol-733 electron microprobe at MIT, and trace elements (in ppm) were measured with a Cameca $6 f$ ion probe at the Department of Terrestrial Magnetism. Glass 1 is common to both olivine and clinopyroxene hosts; glass 2 is commonly found in clinopyroxene host, and glass 3 is found in olivine host. The particular mineral phases listed in the table are all hosted in olivine, and the reported carbonates are all hosted in clinopyroxene, but similar mineral and carbonate compositions were found in clinopyroxene and olivine phenocrysts respectively. The composition of Glass 4 and plagioclase are from Tahaa melt inclusions, the other compositions are from Mangaia melt inclusions. Plag $=$ plagioclase $; \mathrm{Phl}=$ phlogopite; Kaer $=$ kaersutite; $\mathrm{Sp}=$ spinel; $\mathrm{Im}=$ ilmenite; $\mathrm{Sph}=$ sphene; $\mathrm{Ti}-\mathrm{Au}=\mathrm{Ti}$-augite $\mathrm{H}-\mathrm{Cpx}=$ host clinopyroxene $; \mathrm{H}-\mathrm{Ol}=$ host olivine; $\mathrm{Ap}=$ apatite , $\mathrm{Py}=$ chalcopyrite, $\mathrm{Pn}=$ pentlandite, $\mathrm{Po}=$ pyrrothite, $\mathrm{Carb}=$ carbonate. Table 1 lists only representative analyses. A full listing of all of the analyses is reported in the Appendix.

Table 2: $\mathrm{Pb}$ isotopic composition for single melt inclusions from two basalts from Mangaia and one basalt each from Tahaa and Pitcairn island. Analyses of melt pockets and one clinopyroxene from two mantle xenoliths from Tubuaii are also reported. All samples analyzed were silicates except where designated. Two spinel-hosted melt inclusions from Pitcairn were analyzed also.

Appendix: We report major element compositions of representative glasses, daughter mineral phases, carbonates and sulfides from melt inclusions from Mangaia and Tahaa basalts. Each reported analysis is the average of two to four spot analyses. We also report trace element compositions for melt inclusions from both islands. Trace elements (in ppm) were measured with a Cameca $6 \mathrm{f}$ ion probe at the Department of Terrestrial Magnetism (for Mangaia melt inclusions) and with a Cameca $3 f$ ion probe (for Tahaa melt inclusions). In each table, the number corresponds to a number assigned to each melt inclusion. The size of the beam used during the analysis is denoted between parenthesis. Note the different compositions obtained with a small beam $(10 \mu)$ as compared with those of a larger beam $(30 \mu)$ for the same inclusion. The table for olivine compositions reports analyses for olivine hosts. No daughter olivine has been found. The number for each olivine analysis 
represents the melt inclusion number hosted by the olivine. The letters "NI" indicates a second analysis for the same olivine host near the melt inclusion. In the Appendix we report analyses for daughter and host-clinopyroxene. The analyses for the hosts are labeled with an "H". The number is the melt inclusion number the clinopyroxene either hosts or crystallized from. We report analyses for daughter crystals such as amphibole (AMPH), ilmenite (ILM), Ti-magnetite (TI-MNT), plagioclase (PLAG), spinel, sphene, and biotite. Several spinels analyzed are included in olivine phenocrysts ("in OL"). When clinopyroxene or spinel are zoned, the analyses for core and margin are denoted with a "c" or a " $\mathrm{m}$ " respectively. Carbonate and sulfide major element compositions are also included in this appendix as are trace element compositions for melt inclusions, daughter clinopyroxene ("cpx") and carbonates.

\subsection{Figure Caption}

Figure 1: Mass spectrum for ${ }^{206} \mathrm{~Pb},{ }^{207} \mathrm{~Pb}$ and ${ }^{204} \mathrm{~Pb}$ obtained with the IMS Cameca 1270 ion probe. To resolve isobaric interferences, secondary ions were analyzed at a mass resolution of 3500 with no energy filtering. Note that we are able to separate isobaric interferences such as major element and REE oxides. The spectrum was taken on Loihi standard 158-4.

Figure 2: $\mathrm{a}$ and b) Reproducibility of ${ }^{207} \mathrm{~Pb} /{ }^{206} \mathrm{~Pb}$ and ${ }^{206} \mathrm{~Pb} /{ }^{204} \mathrm{~Pb}$ for 34 and 11 analyses of the Loihi 158-4 standard glass used during the course of the melt inclusion analyses respectively. The horizotal lines define the TIMS value reported for the standard and the 2 sigma standard error limits (Garcia et al., 1995). The grey circle define the mean of the 34 and 11 analyses c) ${ }^{208} \mathrm{~Pb} /{ }^{206} \mathrm{~Pb}$ versus ${ }^{207} \mathrm{~Pb} /{ }^{206} \mathrm{~Pb}$ for Loihi $158-4$. The error bars are the 2 sigma in-run (internal) precision. We also add the trends produced by mass fractionation, correlated error in ${ }^{206} \mathrm{~Pb}$, hydride and counting statistics. There is perhaps a small trend in the data in the direction defined by mass fractionation and counting statistics.

Figure 3: BSE microphotograph of two representative melt inclusions. a) Inclusion \#25 from sample MAGB25. The inclusion contains droplets of silicate glass in carbonate spherules, bounded by sharp, curved menisci. Surprisingly, this one melt inclusion contains three different types of silicate glasses (G1; G2; G3) and two different types of carbonates $(\mathrm{C} 1 ; \mathrm{C} 2)$ as reported in Table 1 and Figure 4 and 8 . The host is clinopyroxene; note the crystallization of kaersutite along the contact between the host and the melt 
inclusion. b) Typical and petrographically simple melt inclusion hosted by olivine with crystallization of daughter clinopyroxene; note how the clinopyroxene crystallizes along the contact between the olivine host and the inclusion.

Figure 4: Primitive mantle normalized trace element data for representative melt inclusions from Mangaia. (a) carbonates, (b) silicate glasses contained in the melt inclusions, and (c) whole rock composition for the two Mangaia basalts (Hauri and Hart, 1997). The shaded area defines the compositional range of 46 analyses of melt inclusions. Primitive mantle values are from Sun and McDonough, (1989).

Figure 5: ${ }^{208} \mathrm{~Pb} /{ }^{206} \mathrm{~Pb}$ versus ${ }^{207} \mathrm{~Pb} /{ }^{206} \mathrm{~Pb}$ ratios for whole rock basalts from Pacific MORB, Pitcairn, Marquesas, Society, St. Helena and the Cook-Austral islands. The shaded fields represent $\mathrm{Pb}$ isotopic compositions for the islands and seamounts from the Cook-Austral chain between Mangaia island and Macdonald seamount. The dashed fields represent the Society islands, where the field for Tahaa is highlighted. The field for Pitcairn island and adjacent seamounts is highlighted by verticallines. The data used are from Zindler and Hart (1986); Hauri and Hart, (1993); Hart et al., (1992); Woodhead (1996); Nakamura and Tatsumoto, (1988); Chauvel et al. (1997); Hemond et al., (1994); Eiler et al., (1995); Chauvel et al., (1992); Lassiter, et al. (1998). Large open circles are the four end-members of the mantle tetrahedron (Hart et al., 1992) projected onto the ${ }^{208} \mathrm{~Pb} /{ }^{206} \mathrm{~Pb}$ ${ }^{207} \mathrm{~Pb} /{ }^{206} \mathrm{~Pb}$ plane.

Figure 6: ${ }^{208} \mathrm{~Pb} /{ }^{206} \mathrm{~Pb}$ versus ${ }^{207} \mathrm{~Pb} /{ }^{206} \mathrm{~Pb}$ ratios (Table 2) for individual olivine and clinopyroxene-hosted melt inclusions from Mangaia basalts MAG-B-47 (open circle) and MAG-B-25 (open square). Filled diamonds: sulfide globule and filled square: carbonate globule (both from MAG-B-25); filled triangle: carbonate globule from MAG-B-47. The error bars are in-run precision ( $2 \sigma$, standard error)

Figure 7: ${ }^{208} \mathrm{~Pb} /{ }^{206} \mathrm{~Pb}$ versus ${ }^{207} \mathrm{~Pb} /{ }^{206} \mathrm{~Pb}$ ratios (Table 2) for individual olivine-hosted melt inclusions from Tahaa TAA B 26 (open triangle), Pitcairn PIT 1 (gray filled square) and melt pockets and clinopyroxene from Tubuaii xenoliths TBA 4-11 and TBA 9-11 (open diamond). Inset shows a magnified view of the $\mathrm{Pb}$ isotopic composition for individual olivine-hosted melt inclusions from Tahaa basalt TAA-B-26 (open triangle); filled circle: sulfide globule composition (Table 2$)$. The error bars are in-run precision $(2 \sigma$, standard error) 
Figure 8: $\quad\left(\mathrm{SiO}_{2}+\mathrm{Al}_{2} \mathrm{O}_{3}+\mathrm{TiO}_{2}\right)-(\mathrm{MgO}+\mathrm{FeO} *)-(\mathrm{CaO})-\left(\mathrm{Na}_{2} \mathrm{O}+\mathrm{K}_{2} \mathrm{O}\right) \quad$ generalized pseudoquaternary phase diagram (in weight percent) a) at $1.0 \mathrm{GPa}$ and b) at $2.5 \mathrm{GPa}$ showing the major element compositions for silicate glasses and carbonate globules from Mangaia melt inclusions (Table 1) and from Spitsbergen mantle xenoliths (Ionov et al., 1996). The figures show the three major liquidus volumes (the miscibility gap, silicate and carbonate liquidus fields), and the liquidus surfaces between them. Contours and values for $\left(\mathrm{MgO} \mathrm{FeO}^{*}\right)$ of the surfaces are also shown. Glass 1 - filled triangles; glass 2 filled diamonds; glass 3 - dotted circle; carbonate globules - black circle, black square, grey diamond and open triangles; silicate glasses and carbonate globules from Spitsbergen xenoliths - open diamonds (Ionov et al., 1996); whole rock lavas from Mangaia (MAG-B47 and MAG-B-25 respectively; Hauri and Hart, 1997)) - open circle and open square. The small circles are the projection of each point from the $\left(\mathrm{MgO}+\mathrm{FeO}^{*}\right)$ vertex onto the basal plane of the tetrahedron. The composition of the Mangaia silicate glasses and carbonate globules are very similar to the composition of those found in Spitsbergen xenoliths. The phase relationships at $1.0 \mathrm{GPa}$ and at $2.5 \mathrm{GPa}$ indicate that none of these carbonate and glass compositions represent equilibrium immiscible liquids.

Figure 9: ${ }^{207} \mathrm{~Pb} /{ }^{206} \mathrm{~Pb}$ ratios for single melt inclusions versus the $\mathrm{Cr}$ content of daughter clinopyroxenes from Mangaia (MAG-B-47) and Tahaa (TAA-B-26). The negative correlation suggests that the "less radiogenic component" has suffered differentiation prior to entrapment by the olivine phenocrysts, or that it originated from partial melting of a differentiated source (recycled oceanic crust, eclogite). The error bars for the ${ }^{207} \mathrm{~Pb} /{ }^{206} \mathrm{~Pb}$ ratios are in-run precision ( $2 \mathrm{~s}$ standard errors); for $\mathrm{Cr}$ content the error bars are standard deviation (2s) from replicated analyses. Symbols as in Figure 6 and 7. 
Table 1: Representative mineral, sulfide, glass and carbonate analyses from melt inclusions from samples MAG-B-47, MAG-B-25 and TAA-B-26

\begin{tabular}{|c|c|c|c|c|c|c|c|c|c|c|c|c|}
\hline & Phl & $\mathrm{Ap}$ & Sph & Ilm & Kaer & Sp & Sp & $\mathrm{Ti}-\mathrm{Au}$ & Plag & H- Cpx & $\mathrm{H}-\mathrm{OI}$ & $\mathrm{H}-\mathrm{Ol}$ \\
\hline $\mathrm{SiO}_{2}$ & 43.86 & 2.67 & 30.50 & 0.48 & 38.99 & 0.14 & 0.11 & 40.99 & 54.73 & 51.39 & 39.19 & 39.38 \\
\hline $\mathrm{TiO}_{2}$ & 4.11 & 0.00 & 36.95 & 54.02 & 8.45 & 7.54 & 17.99 & 6.08 & 0.00 & 0.85 & 0.00 & 0.00 \\
\hline $\mathrm{Al}_{2} \mathrm{O}_{3}$ & 13.11 & 0.51 & 1.89 & 0.27 & 14.35 & 17.97 & 5.97 & 12.66 & 28.27 & 3.00 & 0.03 & 0.03 \\
\hline $\mathrm{Cr}_{2} \mathrm{O}_{3}$ & 0.10 & 0.00 & 0.00 & 0.34 & 0.00 & 33.81 & 17.72 & 0.00 & 0.00 & 0.51 & 0.06 & 0.04 \\
\hline $\mathrm{FeO}$ & 9.81 & 1.04 & 0.85 & 37.81 & 10.13 & 33.62 & 54.75 & 10.81 & 0.93 & 5.10 & 16.37 & 13.15 \\
\hline $\mathrm{MnO}$ & 0.12 & 0.00 & 0.00 & 0.73 & 0.11 & 0.44 & 0.75 & 0.21 & 0.00 & 0.20 & 0.05 & 0.22 \\
\hline $\mathrm{MgO}$ & 17.30 & 0.78 & 0.00 & 5.53 & 11.45 & 7.09 & 2.95 & 7.02 & 0.11 & 16.00 & 44.09 & 46.95 \\
\hline $\mathrm{CaO}$ & 0.06 & 51.53 & 29.16 & 0.58 & 12.66 & 0.09 & 0.04 & 22.33 & 10.46 & 22.21 & 0.37 & 0.39 \\
\hline $\mathrm{Na}_{2} \mathrm{O}$ & 0.80 & 0.00 & 0.02 & 0.00 & 2.91 & 0.00 & 0.00 & 0.67 & 2.29 & 0.45 & 0.00 & 0.00 \\
\hline $\mathrm{K}_{2} \mathrm{O}$ & 8.46 & 0.00 & 0.00 & 0.00 & 0.41 & 0.00 & 0.00 & 0.00 & 3.23 & 0.00 & 0.00 & 0.00 \\
\hline $\mathrm{P}_{2} \mathrm{O}_{5}$ & 0.11 & 36.57 & 0.00 & 0.00 & 0.00 & 0.00 & 0.00 & 0.00 & 0.00 & 0.00 & 0.00 & 0.00 \\
\hline $\mathrm{NiO}$ & 0.00 & 0.00 & 0.00 & 0.00 & 0.00 & 0.07 & 0.19 & 0.00 & 0.00 & 0.04 & 0.03 & 0.17 \\
\hline Total & 97.84 & 93.09 & 99.37 & 99.76 & 99.45 & 100.77 & 100.46 & 100.78 & 100.02 & 99.75 & 100.18 & 100.33 \\
\hline \multirow[t]{3}{*}{$\mathrm{Mg \#}$} & 0.80 & 0.62 & 0.00 & 0.24 & 0.71 & 0.32 & 0.11 & 0.59 & 0.20 & 0.87 & 0.86 & 0.89 \\
\hline & & & & & & & & & & & $\begin{array}{c}\text { Fo } 84- \\
86\end{array}$ & $\begin{array}{c}\text { Fo } 86 \\
89\end{array}$ \\
\hline & Cpy & Pn & $\mathrm{Pn}-\mathrm{Po}$ & Po & & & & & & & & \\
\hline $\mathrm{Fe}$ & 39.98 & 33.57 & 58.28 & 60.01 & & & & & & & & \\
\hline Co & 0.13 & 0.68 & 0.18 & 0.13 & & & & & & & & \\
\hline $\mathrm{Ni}$ & 0.33 & 31.59 & 2.16 & 0.32 & & & & & & & & \\
\hline $\mathrm{Cu}$ & 22.07 & 0.27 & 0.22 & 0.16 & & & & & & & & \\
\hline $\mathrm{Zn}$ & 0.15 & 0.21 & 0.12 & 0.18 & & & & & & & & \\
\hline $\mathrm{Pb}$ & 0.18 & 0.00 & 0.00 & 0.00 & & & & & & & & \\
\hline$S$ & 35.58 & 33.03 & 37.95 & 39.39 & & & & & & & & \\
\hline Total & 98.42 & 99.34 & 98.90 & 100.20 & & & & & & & & \\
\hline
\end{tabular}


Table 1: Representative glass and carbonate analyses from melt inclusions from samples MAG-B-47, MAG-B-25 and TAA-B-26 (continuation)

\begin{tabular}{|c|c|c|c|c|c|c|c|c|c|}
\hline & Glass 1 & Glass 1 & Glass 2 & Glass 2 & Glass 3 & Glass 4 & Carb & Carb & Carb \\
\hline $\mathrm{SiO}_{2}$ & 57.39 & 58.61 & 55.07 & 52.95 & 43.69 & 58.53 & 0.02 & 0.71 & 0.19 \\
\hline $\mathrm{TiO}_{2}$ & 0.30 & 0.31 & 0.00 & 0.14 & 0.03 & 0.45 & & & \\
\hline $\mathrm{Al}_{2} \mathrm{O}_{3}$ & 21.54 & 21.74 & 20.78 & 18.84 & 0.99 & 22.04 & & & \\
\hline $\mathrm{Cr}_{2} \mathrm{O}_{3}$ & 0.00 & 0.00 & 0.00 & 0.03 & 0.02 & 0.09 & & & \\
\hline $\mathrm{FeO}$ & 1.86 & 1.62 & 0.51 & 1.83 & 9.41 & 1.08 & 16.76 & 26.86 & 14.73 \\
\hline $\mathrm{MnO}$ & 0.04 & 0.00 & 0.00 & 0.00 & 0.26 & 0.00 & 0.27 & 0.46 & 1.99 \\
\hline $\mathrm{MgO}$ & 0.10 & 0.06 & 0.90 & 1.19 & 30.27 & 0.27 & 30.18 & 11.09 & 4.05 \\
\hline $\mathrm{CaO}$ & 3.42 & 3.09 & 7.92 & 10.44 & 0.16 & 1.44 & 4.26 & 18.20 & 36.10 \\
\hline $\mathrm{Na}_{2} \mathrm{O}$ & 7.81 & 8.00 & 0.31 & 0.37 & 0.00 & 6.43 & 0.38 & 0.15 & 0.08 \\
\hline $\mathrm{K}_{2} \mathrm{O}$ & 2.14 & 2.12 & 0.77 & 0.72 & 0.00 & 6.83 & & & \\
\hline $\mathrm{P}_{2} \mathrm{O}_{5}$ & 1.08 & 0.60 & 0.12 & 2.23 & 0.00 & 0.88 & & & \\
\hline $\mathrm{CO}_{2}$ & & & & & & & 47.05 & 44.31 & 43.40 \\
\hline $\mathrm{NiO}$ & 0.00 & 0.00 & 0.00 & 0.00 & 0.00 & 0.00 & & & \\
\hline Total & 95.68 & 96.15 & 86.39 & 88.75 & 84.84 & 98.02 & 98.94 & 101.77 & 100.54 \\
\hline $\mathrm{Mg} \#$ & 0.10 & 0.08 & 0.80 & 0.59 & 0.88 & 0.36 & & & \\
\hline $\mathrm{Rb}$ & 26.6 & & & 2.76 & 1.78 & & 0.84 & & 4.20 \\
\hline $\mathrm{Ba}$ & 524 & & & 145 & 1.06 & 1077 & 33.3 & & 100 \\
\hline $\mathrm{Nb}$ & 74.9 & & & 7.94 & 8.22 & 42.6 & 29.5 & & 90.7 \\
\hline $\mathrm{La}$ & 131 & & & 6.31 & 4.59 & 51 & 29.9 & & 60.2 \\
\hline $\mathrm{Ce}$ & 232 & & & 10.9 & 8.82 & 76.4 & 54.7 & & 137 \\
\hline $\mathrm{Sr}$ & 972 & & & 14454 & 25.7 & 1022 & 313 & & 10281 \\
\hline $\mathrm{Nd}$ & 78.6 & & & 4.64 & 4.73 & 20.5 & 19.4 & & 57.1 \\
\hline $\mathrm{Sm}$ & 14.9 & & & 0.89 & 0.96 & 2.61 & 2.76 & & 10.9 \\
\hline $\mathrm{Zr}$ & 272 & & & 33.8 & 48.7 & 327 & 112 & & 554 \\
\hline Hf & 4.90 & & & 0.38 & 0.74 & & 1.17 & & 5.31 \\
\hline $\mathrm{Eu}$ & 4.47 & & & 0.18 & 0.27 & & 0.68 & & 3.16 \\
\hline $\mathrm{Ti}$ & 1528 & & & 96.5 & 3087 & 5113 & 805 & & 16049 \\
\hline Gd & 11.0 & & & 0.61 & 0.74 & & 1.35 & & 7.25 \\
\hline Dy & 7.14 & & & 0.45 & 0.56 & 1.11 & 1.24 & & 6.75 \\
\hline $\mathrm{Y}$ & 33.9 & & & 2.70 & 3.42 & 10.5 & 7.67 & & 50 \\
\hline $\mathrm{Er}$ & 2.41 & & & 0.21 & 0.22 & & 0.56 & & 5.29 \\
\hline $\mathrm{Yb}$ & 1.13 & & & 0.14 & 0.18 & 0.41 & 0.59 & & 8.93 \\
\hline
\end{tabular}


Table 2: $\mathrm{Pb}$ isotopic composition of single melt inclusions from samples MAG-B-47, MAG-B-25, TAA-B-26 and PIT 1, and from melt pockets and clinopyroxene TBA 411 and TBA 9-11

\begin{tabular}{|c|c|c|c|c|c|c|}
\hline $\begin{array}{l}\text { MAG B } 47 \\
\text { inclusion \# }\end{array}$ & $207 / 206$ & $\begin{array}{l}\text { in-run error } \\
(2 \mathrm{~s})\end{array}$ & $208 / 206$ & $\begin{array}{l}\text { in-run error } \\
\text { (2s) }\end{array}$ & $206 / 204$ & $\begin{array}{l}\text { in-run error } \\
(2 \mathrm{~s})\end{array}$ \\
\hline 1 & 0.754 & 0.006 & 1.905 & 0.017 & & \\
\hline 2 & 0.743 & 0.005 & 1.887 & 0.013 & & \\
\hline 5 & 0.765 & 0.006 & 1.924 & 0.017 & & \\
\hline 6 & 0.731 & 0.009 & 1.890 & 0.022 & & \\
\hline 8 carbonate & 0.728 & 0.010 & 1.890 & 0.026 & & \\
\hline 8 & 0.745 & 0.008 & 1.894 & 0.023 & & \\
\hline 9 & 0.768 & 0.012 & 1.940 & 0.032 & & \\
\hline 10 & 0.793 & 0.003 & 1.969 & 0.009 & & \\
\hline 11 & 0.793 & 0.004 & 1.974 & 0.014 & & \\
\hline duplicate & 0.804 & 0.009 & 1.979 & 0.024 & & \\
\hline 13 & 0.729 . & 0.007 & 1.861 & 0.021 & & \\
\hline 16 & 0.735 & 0.006 & 1.868 & 0.017 & & \\
\hline 19 & 0.812 & 0.004 & 2.020 & 0.011 & & \\
\hline 23 & 0.738 & 0.003 & 1.892 & 0.011 & & \\
\hline 25 & 0.745 & 0.007 & 1.901 & 0.017 & & \\
\hline $33 \mathrm{~A}$ & 0.727 & 0.008 & 1.864 & 0.022 & & \\
\hline 36 & 0.813 & 0.005 & 2.022 & 0.014 & & \\
\hline 39 & 0.792 & 0.004 & 1.967 & 0.011 & & \\
\hline 42 & 0.744 & 0.004 & 1.883 & 0.010 & & \\
\hline 43 & 0.727 & 0.003 & 1.844 & 0.009 & & \\
\hline 44 & 0.735 & 0.004 & 1.860 & 0.013 & & \\
\hline $45 \mathrm{~A}$ & 0.721 & 0.008 & 1.854 & 0.023 & & \\
\hline 46 & 0.806 & 0.004 & 1.995 & 0.013 & & \\
\hline 48 & 0.805 & 0.003 & 1.987 & 0.008 & & \\
\hline 49 & 0.793 & 0.004 & 1.978 & 0.010 & & \\
\hline 50 & 0.748 & 0.008 & 1.911 & 0.027 & & \\
\hline 52 & 0.706 & 0.009 & 1.840 & 0.027 & & \\
\hline 55 & 0.776 & 0.006 & 1.957 & 0.019 & & \\
\hline 56 & 0.753 & 0.006 & 1.906 & 0.016 & & \\
\hline 57 & 0.803 & 0.003 & 1.986 & 0.007 & 19.64 & 0.31 \\
\hline duplicate & 0.800 & 0.005 & 2.000 & 0.013 & & \\
\hline 58 & 0.783 & 0.011 & 1.964 & 0.026 & & \\
\hline 60 & 0.747 & 0.007 & 1.897 & 0.016 & & \\
\hline 61 & 0.813 & 0.009 & 2.003 & 0.006 & & \\
\hline duplicate & 0.796 & 0.008 & 1.986 & 0.019 & & \\
\hline 67 & 0.727 & 0.009 & 1.866 & 0.025 & & \\
\hline
\end{tabular}


Table 2: Pb isotopic composition of single melt inclusions from samples MAG-B-47, MAG-B-25, TAA-B-26 and PIT 1, and from melt pockets and clinopyroxene TBA 411 and TBA 9-11 (continuation)

\begin{tabular}{|c|c|c|c|c|c|c|}
\hline $\begin{array}{l}\text { MAG B } 25 \\
\text { inclusion \# }\end{array}$ & $207 / 206$ & $\begin{array}{l}\text { in-run error } \\
(2 \mathrm{~s})\end{array}$ & $208 / 206$ & $\begin{array}{c}\text { in-run error } \\
(2 \mathrm{~s})\end{array}$ & $206 / 204$ & $\begin{array}{l}\text { in-run error } \\
(2 s)\end{array}$ \\
\hline 1 & 0.731 & 0.007 & 1.866 & 0.019 & & \\
\hline 2 & 0.750 & 0.008 & 1.916 & 0.022 & & \\
\hline 12 & 0.748 & 0.009 & 1.899 & 0.025 & & \\
\hline 24 & 0.760 & 0.004 & 1.923 & 0.012 & & \\
\hline 25 carbonate & 0.737 & 0.010 & 1.871 & 0.027 & & \\
\hline 25 & 0.731 & 0.002 & 1.866 & 0.005 & 21.46 & 0.12 \\
\hline 28 & 0.732 & 0.005 & 1.865 & 0.013 & & \\
\hline $31 \mathrm{E}$ & 0.740 & 0.003 & 1.891 & 0.009 & & \\
\hline 32 sulfide & 0.727 & 0.002 & 1.865 & 0.007 & 22.01 & 0.16 \\
\hline 35 & 0.808 & 0.009 & 2.003 & 0.022 & & \\
\hline 44 & 0.750 & 0.005 & 1.909 & 0.012 & 21.28 & 0.30 \\
\hline 48 & 0.736 & 0.007 & 1.884 & 0.017 & & \\
\hline 54 & 0.739 & 0.003 & 1.885 & 0.009 & 21.61 & 0.21 \\
\hline $\begin{array}{l}\text { TAA B 26 } \\
\text { inclusion \# }\end{array}$ & $207 / 206$ & $\begin{array}{l}\text { in-run error } \\
\text { (2s) }\end{array}$ & $208 / 206$ & $\begin{array}{c}\text { in-run error } \\
(2 \mathrm{~s})\end{array}$ & $206 / 204$ & $\begin{array}{l}\text { in-run error } \\
(2 s)\end{array}$ \\
\hline 1 & 0.814 & 0.003 & 2.027 & 0.007 & 19.73 & 0.20 \\
\hline E1 & 0.819 & 0.005 & 2.045 & 0.014 & & \\
\hline E2 & 0.815 & 0.004 & 2.033 & 0.010 & & \\
\hline 3 sulfide & 0.821 & 0.005 & 2.043 & 0.016 & & \\
\hline 4 sufide & 0.822 & 0.005 & 2.039 & 0.012 & 19.25 & 0.29 \\
\hline 4 & 0.814 & 0.002 & 2.028 & 0.004 & 19.17 & 0.10 \\
\hline 6 & 0.819 & 0.004 & 2.032 & 0.011 & & \\
\hline 7 & 0.823 & 0.004 & 2.036 & 0.011 & 19.21 & 0.26 \\
\hline 14 & 0.823 & 0.006 & 2.044 & 0.015 & & \\
\hline 20 & 0.816 & 0.003 & 2.022 & 0.008 & & \\
\hline 21 & 0.810 & 0.003 & 2.024 & 0.007 & 19.33 & 0.17 \\
\hline duplicate & 0.818 & 0.004 & 2.028 & 0.009 & & \\
\hline 22 & 0.814 & 0.004 & 2.015 & 0.009 & & \\
\hline 24 & 0.817 & 0.005 & 2.021 & 0.011 & & \\
\hline 28 & 0.809 & 0.003 & 2.023 & 0.007 & & \\
\hline 35 & 0.817 & 0.003 & 2.035 & 0.008 & & \\
\hline 38 & 0.816 & 0.007 & 2.040 & 0.023 & $19.54^{\circ}$ & 0.24 \\
\hline duplicate & 0.814 & 0.004 & 2.034 & 0.011 & & \\
\hline 40 & 0.816 & 0.006 & 2.033 & 0.013 & & \\
\hline 50 & 0.824 & 0.005 & 2.041 & 0.013 & & \\
\hline 51 & 0.809 & 0.008 & 2.048 & 0.020 & & \\
\hline 52 & 0.816 & 0.003 & 2.028 & 0.006 & 18.94 & 0.12 \\
\hline
\end{tabular}


Table 2: Pb isotopic composition of single melt inclusions from samples MAG-B-47, MAG-B-25, TAA-B-26 and PIT 1, and from melt pockets and clinopyroxene TBA 411 and TBA 9-11 (continuation)

\begin{tabular}{|c|c|c|c|c|c|c|}
\hline $\begin{array}{l}\text { TAA B } 26 \\
\text { inclusion \# }\end{array}$ & $207 / 206$ & $\begin{array}{l}\text { in-run error } \\
(2 \mathrm{~s})\end{array}$ & $208 / 206$ & $\begin{array}{c}\text { in-run error } \\
(2 \mathrm{~s})\end{array}$ & $206 / 204$ & $\begin{array}{c}\text { in-run error } \\
(2 \mathrm{~s})\end{array}$ \\
\hline 54 & 0.811 & 0.007 & 2.027 & 0.022 & & \\
\hline 59 & 0.816 & 0.003 & 2.026 & 0.008 & & \\
\hline 60 & 0.817 & 0.003 & 2.033 & 0.008 & & \\
\hline 61 & 0.810 & 0.003 & 2.013 & 0.009 & & \\
\hline $62 \mathrm{E}$ & 0.815 & 0.003 & 2.030 & 0.007 & 19.26 & 0.16 \\
\hline 62 & 0.820 & 0.006 & 2.036 & 0.014 & & \\
\hline 63 & 0.818 & 0.003 & 2.032 & 0.008 & & \\
\hline 65 & 0.812 & 0.004 & 2.009 & 0.013 & 19.27 & 0.21 \\
\hline 68 & 0.814 & 0.003 & 2.023 & 0.009 & & \\
\hline 69 & 0.815 & 0.007 & 2.023 & 0.017 & & \\
\hline $\begin{array}{c}\text { PIT 1 } \\
\text { inclusion \# }\end{array}$ & $207 / 206$ & $\begin{array}{c}\text { in-run error } \\
(2 \mathrm{~s})\end{array}$ & $208 / 206$ & $\begin{array}{l}\text { in-run error } \\
(2 s)\end{array}$ & & \\
\hline $5 \mathrm{~A}$ & 0.850 & 0.002 & 2.118 & 0.006 & & \\
\hline 22 & 0.864 & 0.008 & 2.159 & 0.019 & & \\
\hline 23A spinel & 0.868 & 0.004 & 2.154 & 0.009 & & \\
\hline $25 \mathrm{~B}$ & 0.865 & 0.003 & 2.165 & 0.008 & & \\
\hline $27 \mathrm{~A}$ & 0.870 & 0.004 & 2.177 & 0.010 & & \\
\hline $32 \mathrm{~A}$ & 0.874 & 0.002 & 2.196 & 0.006 & & \\
\hline $46 \mathrm{~A}$ & 0.841 & 0.008 & 2.054 & 0.022 & & \\
\hline $48 \mathrm{~A}$ & 0.875 & 0.004 & 2.190 & 0.009 & & \\
\hline $52 \mathrm{~A}$ & 0.849 & 0.003 & 2.116 & 0.008 & & \\
\hline 54 spinel & 0.849 & 0.006 & 2.089 & 0.017 & & \\
\hline 59 & 0.863 & 0.004 & 2.173 & 0.012 & & \\
\hline $73 \mathrm{~A}$ & 0.874 & 0.003 & 2.195 & 0.008 & & \\
\hline 81 & 0.865 & 0.007 & 2.170 & 0.019 & & \\
\hline $81 B$ & 0.865 & 0.003 & 2.177 & 0.008 & & \\
\hline $83 \mathrm{~A}$ & 0.870 & 0.006 & 2.185 & 0.015 & & \\
\hline $89 \mathrm{~A}$ & 0.858 & 0.003 & 2.154 & 0.007 & & \\
\hline $91 \mathrm{~B}$ & 0.874 & 0.011 & 2.160 & 0.026 & & \\
\hline $\begin{array}{c}\text { TBA } \\
\text { inclusion \# }\end{array}$ & $207 / 206$ & $\begin{array}{l}\text { in-run error } \\
(2 \mathrm{~s})\end{array}$ & $208 / 206$ & $\begin{array}{l}\text { in-run error } \\
(2 \mathrm{~s})\end{array}$ & $206 / 204$ & $\begin{array}{l}\text { in-run error } \\
\text { (2s) }\end{array}$ \\
\hline $9-1$ melt 1 & 0.748 & 0.002 & 1.922 & 0.005 & 21.07 & 0.08 \\
\hline $9-1$ melt 2 & 0.750 & 0.001 & 1.925 & 0.003 & 21.12 & 0.13 \\
\hline $9-1$ melt 3 & 0.746 & 0.002 & 1.918 & 0.007 & & \\
\hline 9-1 cpx & 0.756 & 0.005 & 1.914 & 0.014 & 21.32 & 0.06 \\
\hline 4-11 melt 1 & 0.749 & 0.003 & 1.920 & 0.008 & 21.16 & 0.20 \\
\hline 4-11 melt 2 & 0.749 & 0.003 & 1.916 & 0.008 & 21.16 & 0.17 \\
\hline
\end{tabular}



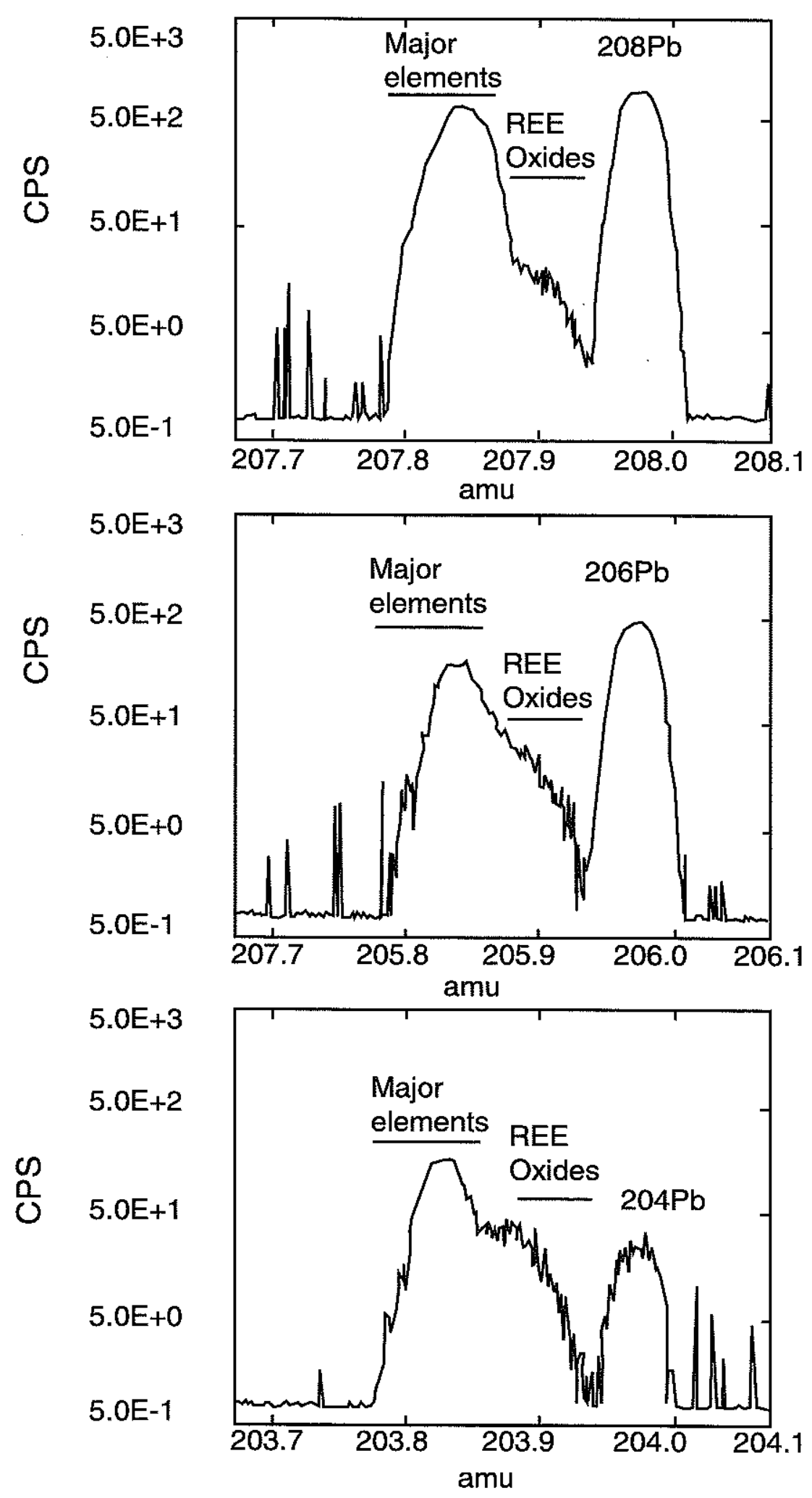

Figure 1 
Loihi 158-4
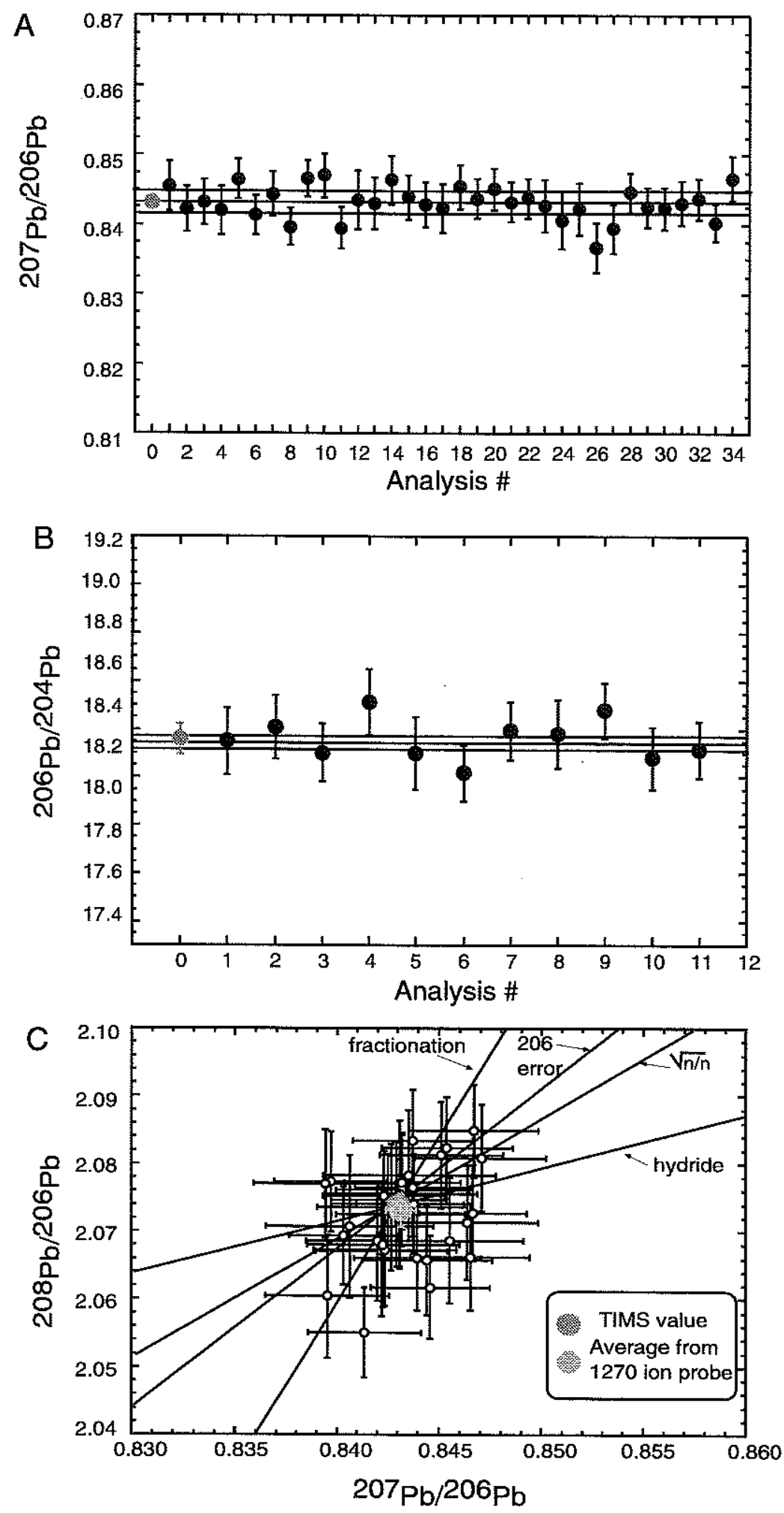

Figure 2 

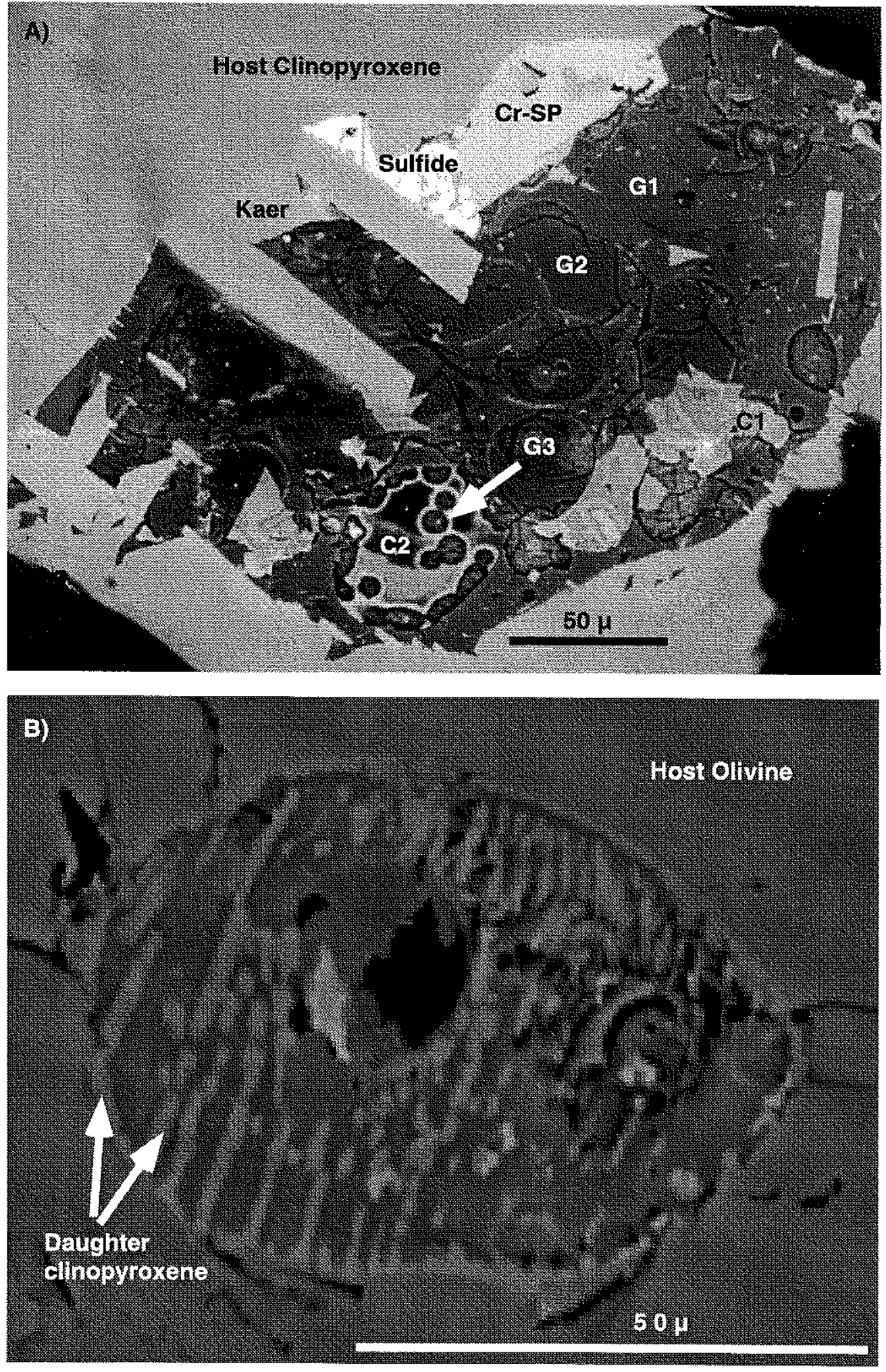

Figure 3 


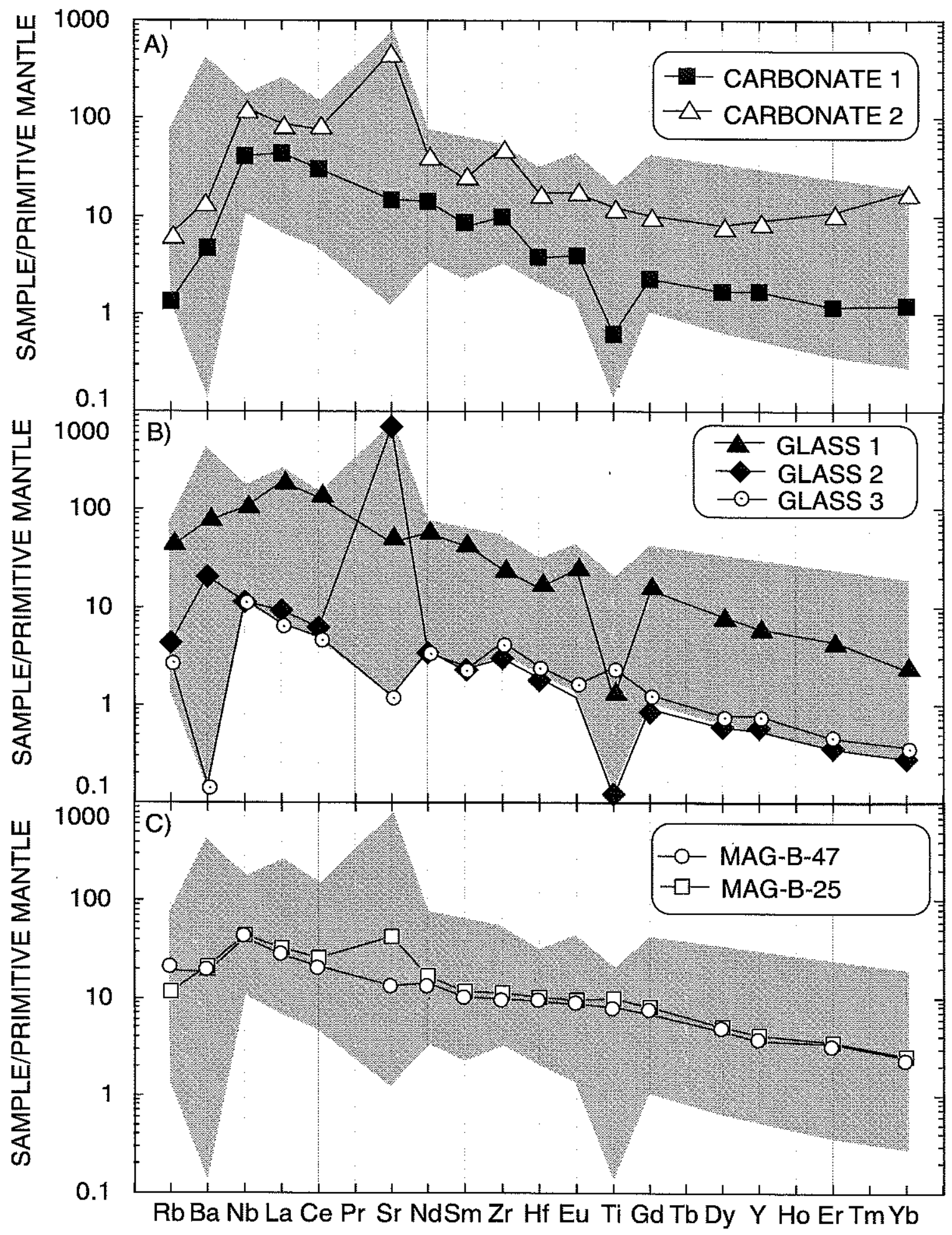

Figure 4 


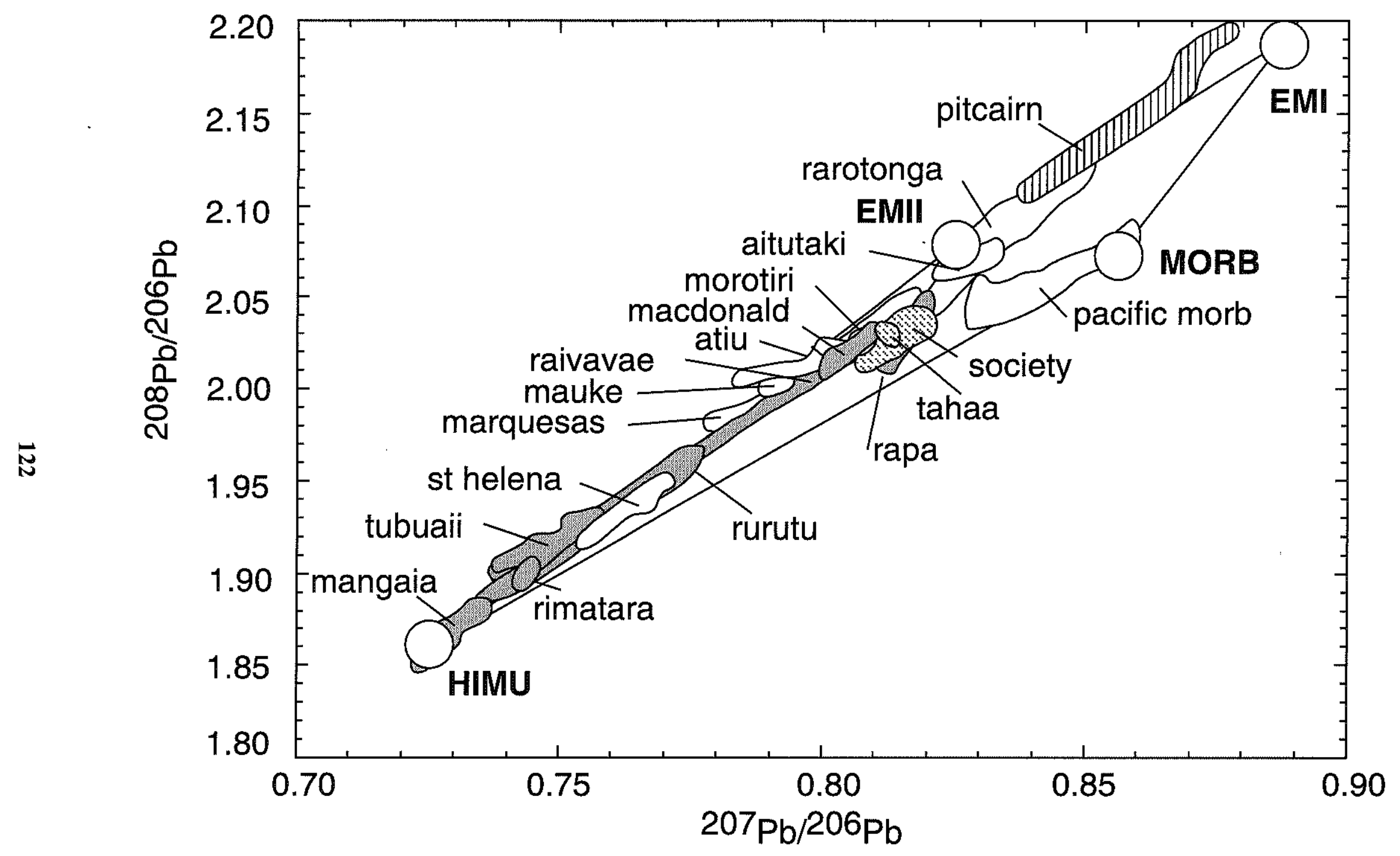

Figure 5 


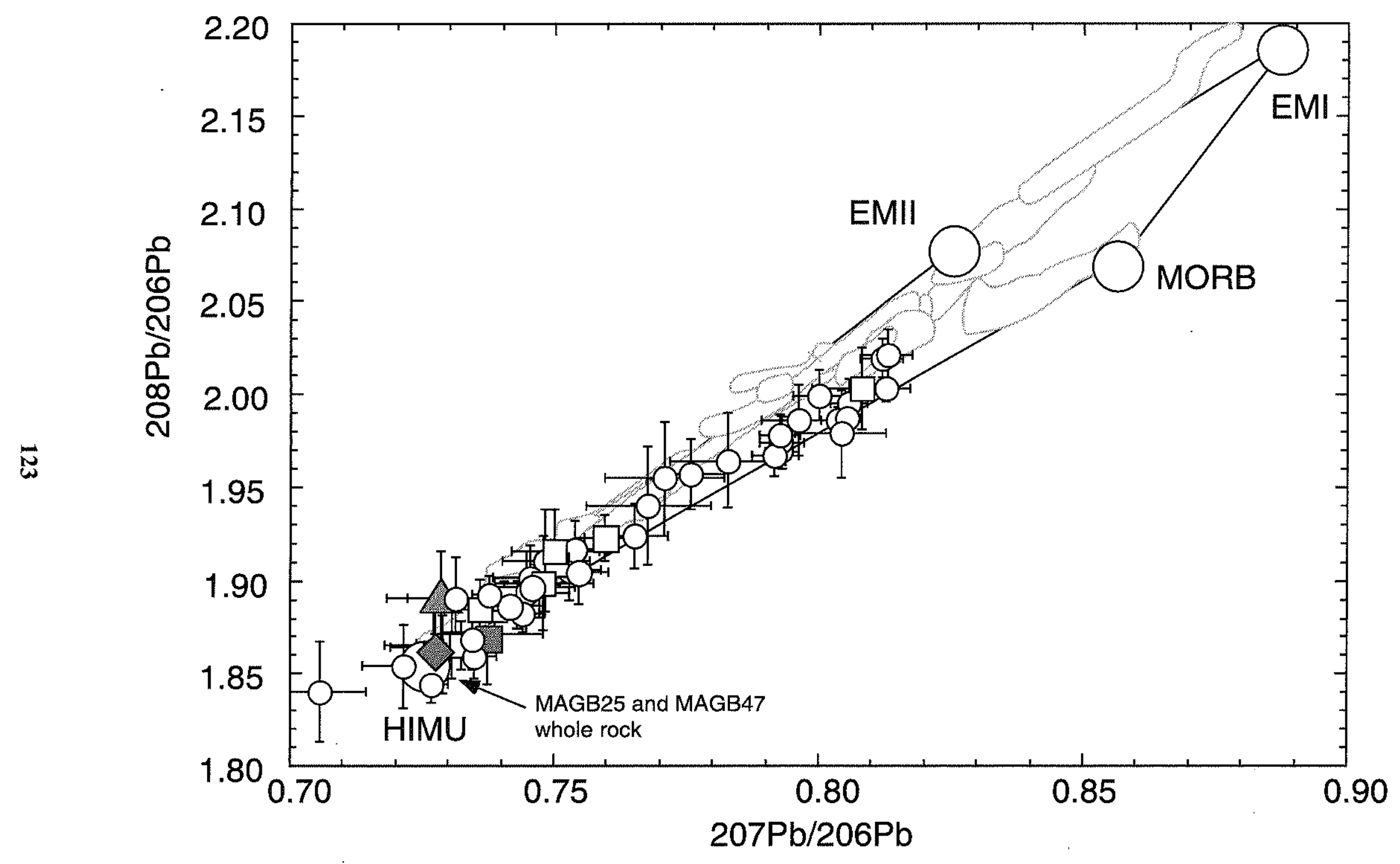

Figure 6 


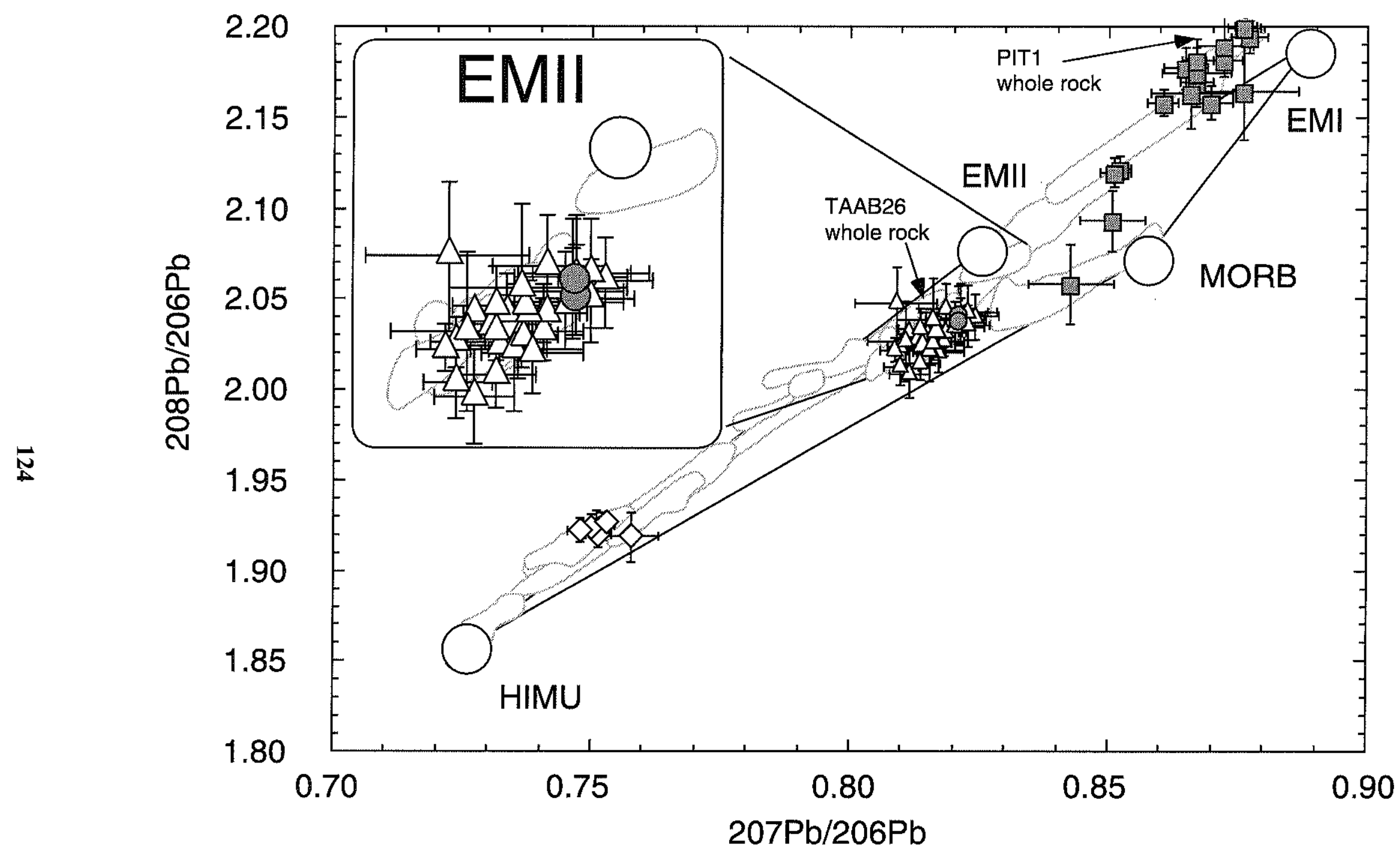

Figure 7 


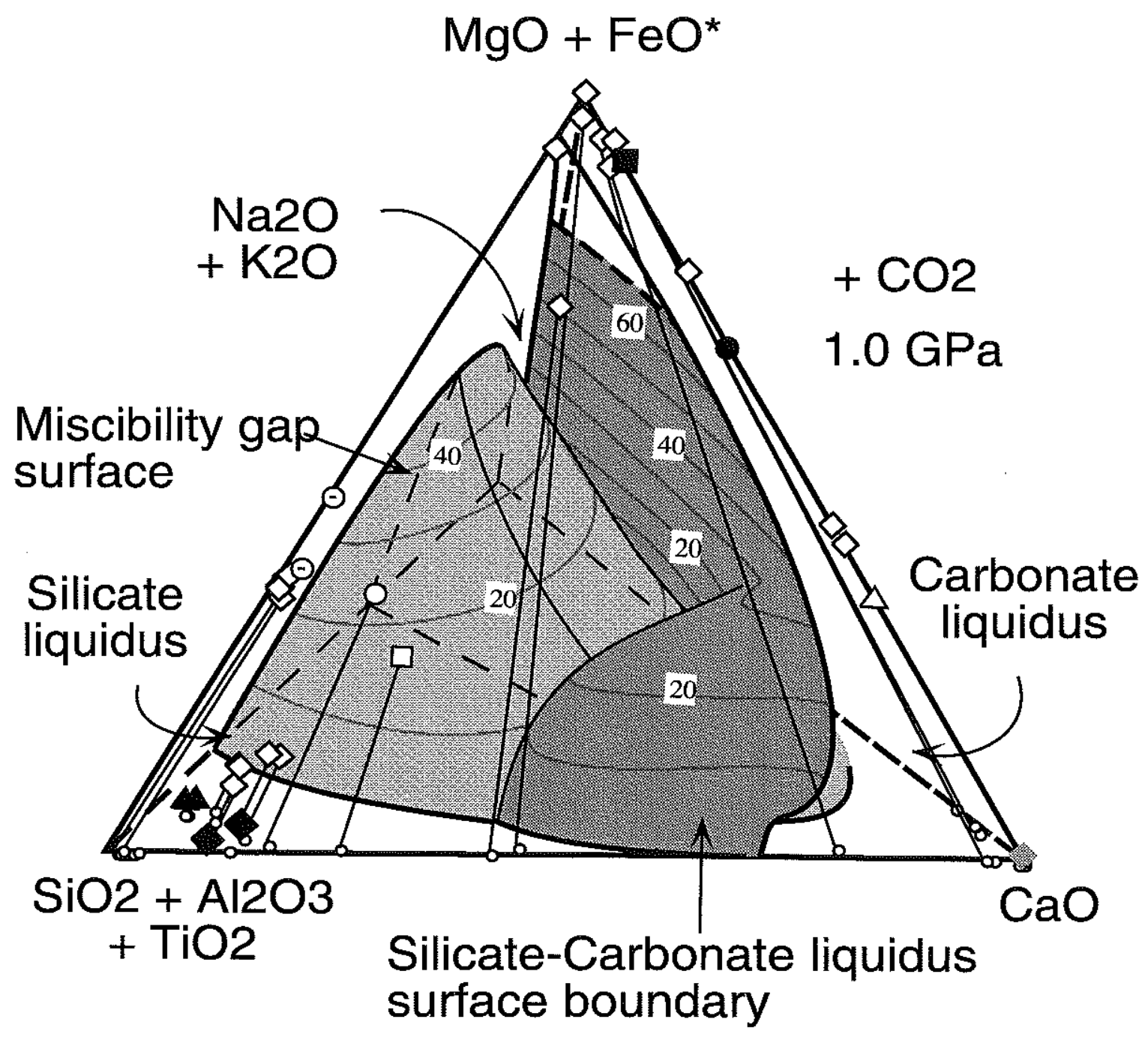

Figure $8 a$ 


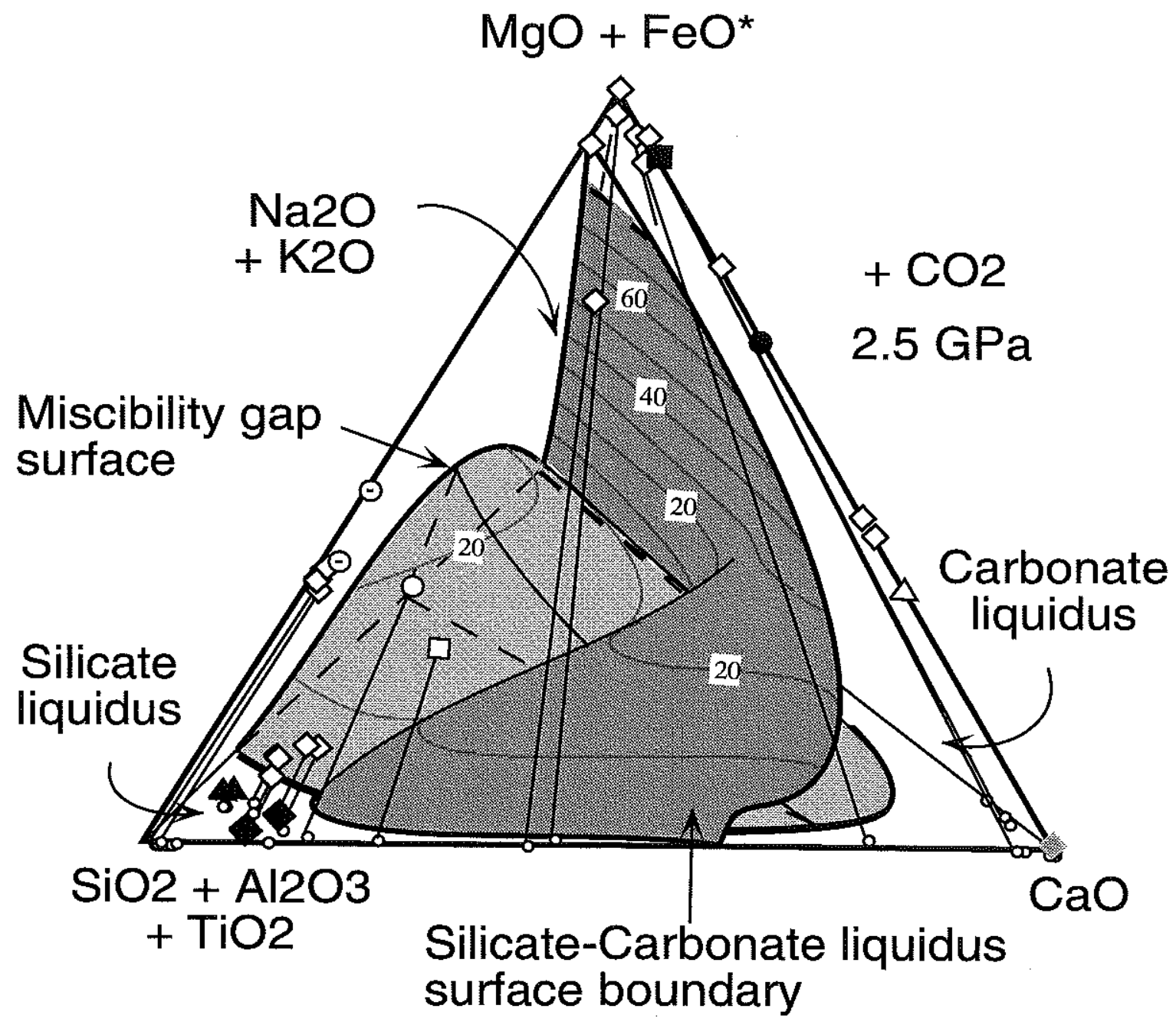

Figure $8 b$ 


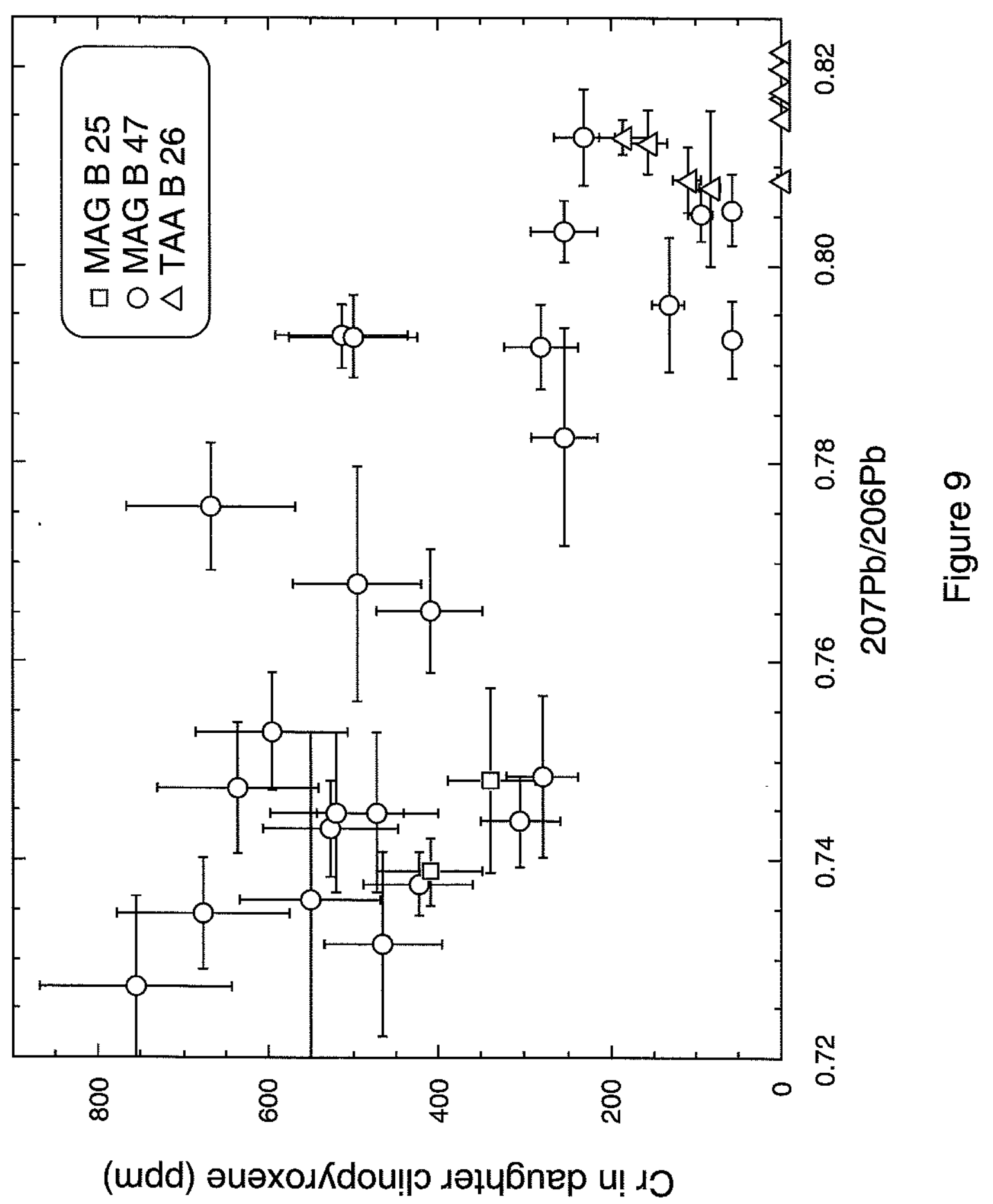


APPENDIX TABLE 1: Major element composition of melt inclusions

\begin{tabular}{|c|c|c|c|c|c|c|c|c|c|c|c|c|c|c|}
\hline$\overline{M A G B} 47$ & $1(30 \mu)$ & $2(10 \mu)$ & $2(30 \mu)$ & $3(10 \mu)$ & $3(30 \mu)$ & $5(10 \mu)$ & $5(30 \mu)$ & $6(10 \mu)$ & $6(30 \mu)$ & $7(10 \mu)$ & $7(30 \mu)$ & $8(10 \mu)$ & $8(30 \mu)$ & $9(10 \mu)$ \\
\hline $\mathrm{SiO} 2$ & 53.54 & 58.43 & 51.60 & 62.28 & 52.79 & 51.47 & 49.98 & 61.60 & 52.79 & 59.65 & 55.00 & 40.78 & 41.62 & 61.02 \\
\hline $\mathrm{TiO} 2$ & 2.16 & 0.17 & 2.75 & 0.29 & 2.15 & 0.24 & 2.06 & 0.05 & 2.09 & 0.23 & 1.80 & 0.08 & 2.50 & 0.07 \\
\hline $\mathrm{A} 12 \mathrm{O} 3$ & 20.07 & 29.24 & 18.61 & 25.74 & 19.24 & 28.27 & 19.67 & 25.25 & 18.91 & 24.38 & 20.54 & 0.06 & 4.71 & 25.51 \\
\hline $\mathrm{Cr} 2 \mathrm{O} 3$ & 0.03 & 0.02 & 0.12 & 0.04 & 0.10 & 0.04 & 0.02 & 0.01 & 0.02 & 0.01 & 0.01 & 0.01 & 0.04 & 0.02 \\
\hline $\mathrm{FeO}$ & 3.63 & 0.93 & 3.90 & 1.04 & 3.97 & 1.00 & 5.60 & 0.97 & 3.67 & 1.11 & 3.18 & 10.07 & 10.01 & 0.53 \\
\hline $\mathrm{MnO}$ & 0.09 & 0.01 & 0.12 & 0.03 & 0.07 & 0.03 & 0.05 & 0.01 & 0.02 & 0.01 & 0.02 & 0.20 & 0.18 & 0.00 \\
\hline $\mathrm{MgO}$ & 3.74 & 0.05 & 4.71 & 0.26 & 2.89 & 0.26 & 2.58 & 0.01 & 4.09 & 0.36 & 3.43 & 33.02 & 22.01 & 0.01 \\
\hline $\mathrm{CaO}$ & 8.61 & 0.46 & 11.95 & 1.40 & 9.23 & 9.70 & 11.32 & 0.77 & 10.02 & 1.35 & 7.79 & 0.30 & 9.37 & 1.02 \\
\hline $\mathrm{Na} 2 \mathrm{O}$ & 6.57 & 8.50 & 5.13 & 7.32 & 6.97 & 5.17 & 5.89 & 8.92 & 6.71 & 9.16 & 5.46 & 0.00 & 0.35 & 10.17 \\
\hline $\mathrm{K} 2 \mathrm{O}$ & 1.55 & 2.98 & 1.51 & 2.82 & 1.75 & 3.39 & 2.83 & 3.96 & 2.25 & 3.73 & 2.51 & 0.00 & 0.04 & 2.70 \\
\hline $\mathrm{P} 2 \mathrm{O} 5$ & 0.25 & 0.07 & 0.29 & 0.15 & 0.60 & 0.22 & 0.39 & 0.29 & 0.21 & 0.14 & 0.32 & 0.03 & 0.35 & 0.00 \\
\hline $\mathrm{NiO}$ & 0.00 & 0.00 & 0.00 & 0.00 & 0.00 & 0.00 & 0.00 & 0.00 & 0.00 & 0.00 & 0.00 & 0.00 & 0.00 & 0.00 \\
\hline Total & 100.24 & 100.86 & 100.69 & 101.37 & 99.76 & 99.79 & 100.38 & 101.84 & 100.77 & 100.14 & 100.06 & 84.55 & 91.17 & 101.04 \\
\hline Mg\# & 0.70 & 0.11 & 0.73 & 0.31 & 0.62 & 0.36 & 0.50 & 0.03 & 0.71 & 0.40 & 0.70 & 0.88 & 0.83 & 0.03 \\
\hline MAG B 25 & $1(15 \mu)$ & $1(5 \mu)$ & $2(5 \mu)$ & $2(10 \mu)$ & $3(10 \mu)$ & $3(15 \mu)$ & $4(10 \mu)$ & $5(20 \mu)$ & $7(10 \mu)$ & $8(5 \mu)$ & $9(5 \mu)$ & $11 \mathrm{~A}(5 \mu)$ & $12(5 \mu)$ & $13(5 \mu)$ \\
\hline $\mathrm{SiO} 2$ & 59.42 & 60.73 & 61.83 & 48.93 & 57.39 & 43.03 & 51.36 & 51.94 & 58.11 & 54.25 & 56.40 & 60.61 & 61.44 & 61.05 \\
\hline $\mathrm{TiO}_{2}$ & 0.14 & 0.08 & 0.12 & 2.34 & 0.30 & 4.10 & 0.00 & 0.02 & 0.02 & 0.02 & 0.00 & 0.07 & 0.09 & 0.12 \\
\hline Al2O3 & 21.45 & 23.43 & 20.81 & 17.17 & 21.54 & 11.56 & 21.22 & 21.09 & 18.96 & 21.67 & 20.77 & 22.43 & 23.91 & 21.31 \\
\hline $\mathrm{Cr} 2 \mathrm{O} 3$ & 0.00 & 0.03 & 0.00 & 0.00 & 0.00 & 0.04 & 0.00 & 0.00 & 0.00 & 0.00 & 0.00 & 0.00 & 0.00 & 0.00 \\
\hline $\mathrm{FeO}$ & 1.49 & 1.15 & 1.11 & 7.91 & 1.86 & 10.74 & 0.61 & 0.91 & 2.69 & 0.02 & 0.00 & 0.00 & 1.24 & 0.00 \\
\hline $\mathrm{MnO}$ & 0.37 & 0.06 & 0.00 & 0.14 & 0.04 & 0.67 & 0.23 & 0.10 & 0.09 & 0.00 & 0.00 & 0.00 & 0.04 & 0.00 \\
\hline $\mathrm{MgO}$ & 0.00 & 0.02 & 0.11 & 4.89 & 0.10 & 8.37 & 0.40 & 0.93 & 3.08 & 0.65 & 0.81 & 0.00 & 0.11 & 0.03 \\
\hline $\mathrm{CaO}$ & 2.89 & 2.83 & 1.30 & 6.72 & 3.42 & 17.05 & 8.50 & 8.17 & 2.11 & 9.46 & 8.16 & 2.45 & 1.27 & 1.20 \\
\hline $\mathrm{Na} 2 \mathrm{O}$ & 8.46 & 7.54 & 9.15 & 6.59 & 7.81 & 1.76 & 0.00 & 0.22 & 2.48 & 1.05 & 0.33 & 9.11 & 7.01 & 10.22 \\
\hline $\mathrm{K} 2 \mathrm{O}$ & 1.97 & 2.11 & 2.96 & 1.74 & 2.14 & 0.42 & 0.03 & 0.18 & 2.08 & 2.23 & 0.51 & 2.34 & 3.08 & 2.68 \\
\hline P205 & 0.41 & 0.81 & 0.19 & 0.40 & 1.08 & 0.44 & 0.07 & 0.04 & 1.31 & 0.70 & 0.08 & 0.30 & 0.68 & 0.62 \\
\hline $\mathrm{NiO}$ & 0.00 & 0.00 & 0.00 & 0.00 & 0.00 & 0.00 & 0.00 & 0.00 & 0.00 & 0.00 & 0.00 & 0.00 & 0.00 & 0.00 \\
\hline Total & 96.59 & 98.78 & 97.59 & 96.83 & 95.68 & 98.15 & 82.42 & 83.59 & 90.92 & $90: 04$ & 87.06 & 97.31 & 98.87 & 97.23 \\
\hline $\mathrm{Mg} \#$ & 0.00 & 0.04 & 0.18 & 0.58 & 0.10 & 0.63 & 0.60 & 0.70 & 0.72 & 0.99 & 1.00 & 0.00 & 0.16 & 1.00 \\
\hline TAA B 26 & $1(20 \mu)$ & $2(20 \mu)$ & $3(20 \mu)$ & $4(20 \mu)$ & $5(20 \mu)$ & $6(20 \mu)$ & $6(5 \mu)$ & $8(20 \mu)$ & $9(20 \mu)$ & $10(5 \mu)$ & $10(10 \mu)$ & $12(20 \mu)$ & $14(10 \mu)$ & $15(10 \mu)$ \\
\hline $\mathrm{SiO}_{2}$ & 58.53 & 57.61 & 59.08 & 58.96 & 61.25 & 58.04 & 62.11 & 56.53 & 56.72 & 60.62 & 50.37 & 58.09 & 59.56 & 58.42 \\
\hline $\mathrm{TiO} 2$ & 0.45 & 0.49 & 0.41 & 0.39 & 0.43 & 0.41 & 0.28 & 1.48 & 0.44 & 0.44 & 5.62 & 1.50 & 0.42 & 0.39 \\
\hline $\mathrm{Al} 2 \mathrm{O} 3$ & 22.04 & 22.66 & 21.90 & 22.28 & 22.37 & 21.40 & 21.96 & 18.38 & 23.95 & 21.44 & 17.34 & 18.83 & 21.68 & 22.71 \\
\hline $\mathrm{Cr} 2 \mathrm{O} 3$ & 0.09 & 0.00 & 0.00 & 0.00 & 0.00 & 0.00 & 0.00 & 0.02 & 0.00 & 0.00 & 0.01 & 0.00 & 0.00 & 0.00 \\
\hline $\mathrm{FeO}$ & 1.08 & 1.16 & 1.44 & 1.33 & 1.06 & 1.19 & 1.08 & 3.79 & 1.32 & 1.06 & 6.33 & 1.51 & 1.65 & 1.38 \\
\hline Mno & 0.00 & 0.03 & 0.07 & 0.03 & 0.06 & 0.04 & 0.05 & 0.09 & 0.04 & 0.02 & 0.14 & 0.06 & 0.03 & 0.06 \\
\hline $\mathrm{MgO}$ & 0.27 & 0.25 & 0.13 & 0.10 & 0.24 & 0.21 & 0.19 & 1.42 & 0.34 & 0.26 & 5.07 & 0.14 & 0.54 & 0.46 \\
\hline $\mathrm{CaO}$ & 1.44 & 1.73 & 1.78 & 1.60 & 1.17 & 2.49 & 1.38 & 9.10 & 2.13 & 0.99 & 6.69 & 7.97 & 2.42 & 1.83 \\
\hline $\mathrm{Na} 2 \mathrm{O}$ & 6.43 & 6.78 & 6.80 & 7.25 & 6.66 & 7.22 & 3.52 & 4.73 & 8.68 & 6.69 & 4.33 & 6.52 & 6.87 & 7.48 \\
\hline $\mathrm{K} 2 \mathrm{O}$ & 6.83 & 6.45 & 7.17 & 6.08 & 6.80 & 6.51 & 4.94 & 3.85 & 4.54 & 6.95 & 4.35 & 3.45 & 5.82 & 4.64 \\
\hline P2O5 & 0.88 & 1.16 & 0.76 & 0.50 & 0.94 & 1.37 & 0.59 & 0.96 & 1.41 & 0.98 & 0.79 & 1.71 & 0.77 & 0.98 \\
\hline $\mathrm{NiO}$ & 0.00 & 0.00 & 0.00 & 0.00 & 0.00 & 0.00 & 0.00 & 0.00 & 0.00 & 0.00 & 0.00 & 0.00 & 0.00 & 0.00 \\
\hline Total & 98.02 & 98.30 & 99.53 & 98.52 & 100.97 & 98.88 & 96.09 & 100.34 & 99.55 & 99.46 & 101.05 & 99.77 & 99.76 & 98.34 \\
\hline $\mathrm{Mg} \#$ & 0.36 & 0.32 & 0.17 & 0.15 & 0.34 & 0.28 & 0.28 & 0.45 & 0.36 & 0.35 & 0.64 & 0.17 & 0.42 & 0.42 \\
\hline
\end{tabular}


APPENDIX TABLE 1: Major element composition of melt inclusions

\begin{tabular}{|c|c|c|c|c|c|c|c|c|c|c|c|c|c|c|}
\hline MAG B 47 & $9(30 \mu)$ & $12(20 \mu)$ & $13(10 \mu)$ & $13(30 \mu)$ & $14(10 \mu)$ & $14(30 \mu)$ & $15(10 \mu)$ & $15(30 \mu)$ & $16(30 \mu)$ & $17(10 \mu)$ & $17(30 \mu)$ & $18(10 \mu)$ & $18(30 \mu)$ & $21(20 \mu)$ \\
\hline $\mathrm{SiO} 2$ & 53.98 & 39.39 & 40.99 & 42.55 & 55.27 & 48.03 & 35.40 & 36.44 & 54.08 & 52.51 & 49.36 & 61.79 & 50.65 & 44.75 \\
\hline $\mathrm{TiO} 2$ & 1.34 & 0.04 & 0.05 & 0.42 & 0.76 & 2.97 & 0.06 & 1.63 & 0.71 & 0.35 & 2.24 & 0.19 & 2.72 & 0.03 \\
\hline $\mathrm{A} 12 \mathrm{O} 3$ & 20.05 & 0.00 & 0.20 & 0.84 & 24.93 & 15.85 & 6.74 & 8.58 & 20.95 & 25.66 & 19.48 & 23.19 & 19.36 & 22.37 \\
\hline $\mathrm{Cr} 2 \mathrm{O} 3$ & 0.03 & 0.04 & 0.05 & 0.05 & 0.09 & 0.12 & 0.28 & 0.38 & 0.03 & 0.02 & 0.03 & 0.02 & 0.03 & 0.02 \\
\hline $\mathrm{FeO}$ & 3.37 & 26.70 & 11.79 & 9.43 & 1.17 & 4.31 & 24.32 & 11.36 & 2.23 & 1.04 & 3.79 & 1.03 & 4.16 & 2.87 \\
\hline $\mathrm{MnO}$ & 0.02 & 0.35 & 0.19 & 0.21 & 0.00 & 0.09 & 0.26 & 0.06 & 0.05 & 0.00 & 0.04 & 0.00 & 0.06 & 0.27 \\
\hline $\mathrm{MgO}$ & 2.07 & 32.24 & 32.31 & 32.33 & 1.54 & 7.78 & 19.14 & 18.40 & 1.00 & 0.70 & 5.25 & 0.27 & 4.10 & 1.46 \\
\hline $\mathrm{CaO}$ & 8.91 & 0.41 & 0.07 & 0.10 & 3.78 & 15.36 & 0.43 & 10.30 & 13.21 & 3.60 & 9.01 & 1.39 & 10.37 & 7.43 \\
\hline $\mathrm{Na} 2 \mathrm{O}$ & 8.05 & 0.00 & 0.01 & 0.00 & 10.88 & 4.52 & 0.08 & 0.63 & $\cdot 7.18$ & 14.18 & 9.76 & 10.91 & 7.11 & 0.06 \\
\hline $\mathrm{K} 2 \mathrm{O}$ & 1.83 & 0.00 & 0.01 & 0.01 & 2.83 & 0.90 & 0.05 & 0.12 & 0.92 & 1.57 & 1.30 & 2.82 & 1.81 & 2.10 \\
\hline P2O5 & 1.21 & 0.14 & 0.00 & 0.00 & 0.38 & 0.35 & 0.00 & 0.94 & 0.22 & 1.41 & 0.28 & 0.32 & 0.69 & 0.00 \\
\hline $\mathrm{NiO}$ & 0.00 & 0.00 & 0.00 & 0.00 & 0.00 & 0.00 & 0.00 & 0.00 & 0.00 & 0.00 & 0.00 & 0.00 & 0.00 & 0.00 \\
\hline Total & 100.85 & 99.32 & 85.67 & 85.94 & 101.64 & 100.27 & 86.75 & 88.83 & 100.58 & 101.02 & 100.54 & 101.92 & 101.06 & 81.36 \\
\hline Mg\# & 0.57 & 0.73 & 0.86 & 0.88 & 0.74 & 0.80 & 0.63 & 0.78 & 0.34 & 0.60 & 0.75 & 0.37 & 0.69 & 0.53 \\
\hline
\end{tabular}

\begin{tabular}{|c|c|c|c|c|c|c|c|c|c|c|c|c|c|c|}
\hline MAG B 25 & $14(15 \mu)$ & $15(25 \mu)$ & $15(5 \mu)$ & $24(5 \mu)$ & $24(5 \mu)$ & $25(5 \mu)$ & $25(5 \mu)$ & $25(5 \mu)$ & $27(10 \mu)$ & $28(5 \mu)$ & $29(5 \mu)$ & $30(5 \mu)$ & $31(5 \mu)$ & $31 \mathrm{~A}(5 \mu)$ \\
\hline $\mathrm{SiO} 2$ & 40.15 & 48.23 & 62.15 & 51.93 & 58.28 & 54.01 & 48.26 & 58.87 & 51.08 & 57.77 & 47.30 & 50.14 & 59.09 & 56.07 \\
\hline $\mathrm{TiO} 2$ & 6.38 & 1.88 & 0.19 & 0.12 & 0.23 & 0.07 & 0.21 & 0.20 & 0.09 & 0.21 & 0.04 & 0.05 & 0.10 & 0.27 \\
\hline $\mathrm{Al} 2 \mathrm{O} 3$ & 13.26 & 16.06 & 20.89 & 20.52 & 22.56 & 20.03 & 9.02 & 21.48 & 19.75 & 21.40 & 18.92 & 0.85 & 20.74 & 23.77 \\
\hline $\mathrm{Cr} 2 \mathrm{O} 3$ & 0.02 & 0.04 & 0.02 & 0.03 & 0.00 & 0.01 & 0.01 & 0.00 & 0.02 & 0.01 & 0.00 & 0.08 & 0.02 & 0.00 \\
\hline $\mathrm{FeO}$ & 10.82 & 7.37 & 1.05 & 1.11 & 1.31 & 0.81 & 12.96 & 1.53 & 2.10 & 0.94 & 1.45 & 23.00 & 0.73 & 1.44 \\
\hline $\mathrm{MnO}$ & 0.00 & 0.14 & 0.04 & 0.03 & 0.10 & 0.01 & 0.07 & 0.00 & 0.00 & 0.00 & 0.00 & 0.00 & 0.00 & 0.00 \\
\hline $\mathrm{MgO}$ & 4.64 & 5.12 & 0.06 & 0.60 & 0.06 & 0.95 & 11.45 & 0.12 & 0.85 & 0.04 & 0.68 & 11.23 & 0.04 & 0.23 \\
\hline $\mathrm{CaO}$ & 17.64 & 9.90 & 2.19 & 7.62 & 3.95 & 8.39 & 1.97 & 3.19 & 9.55 & 3.36 & 8.32 & 1.50 & 4,03 & 7.65 \\
\hline $\mathrm{Na} 2 \mathrm{O}$ & 1.52 & 5.43 & 8.37 & 0.50 & 6.45 & 0.29 & 0.22 & 7.90 & 0.61 & 8.64 & 0.11 & 0.16 & 8.14 & 7.39 \\
\hline $\mathrm{K} 2 \mathrm{O}$ & 0.52 & 1.36 & 2.82 & 0.58 & 2.25 & 0.66 & 0.36 & 2.17 & 1.10 & 2.33 & 0.20 & 0.41 & 2.20 & 0.41 \\
\hline $\mathrm{P} 2 \mathrm{O} 5$ & 0.82 & 0.77 & 0.90 & 0.46 & 1.06 & 0.50 & 0.26 & 0.84 & 1.11 & 1.05 & 0.13 & 0.20 & 1.65 & 1.21 \\
\hline $\mathrm{NiO}$ & 0.00 & 0.00 & 0.00 & 0.00 & 0.00 & 0.00 & 0.00 & 0.00 & 0.00 & 0.00 & 0.00 & 0.00 & 0.00 & 0.00 \\
\hline Total & 95.77 & 96.28 & 98.67 & 83.50 & 96.24 & 85.73 & 84.80 & 96.30 & 86.25 & 95.75 & 77.14 & 87.62 & 96.73 & 98.44 \\
\hline $\mathrm{Mg} \#$ & 0.49 & 0.61 & 0.11 & 0.57 & 0.09 & 0.75 & 0.66 & 0.14 & 0.54 & 0.07 & 0.64 & 0.52 & 0.10 & 0.22 \\
\hline
\end{tabular}

\begin{tabular}{|c|c|c|c|c|c|c|c|c|c|c|c|c|c|c|}
\hline TAA B 26 & $16(10 \mu)$ & $17(10 \mu)$ & $18(20 \mu)$ & $20(20 \mu)$ & $21(20 \mu)$ & $22(30 \mu)$ & $23(30 \mu)$ & $24(30 \mu)$ & $26(10 \mu)$ & $28(30 \mu)$ & $30(30 \mu)$ & $30(10 \mu)$ & $32(30 \mu)$ & $33(20 \mu)$ \\
\hline $\mathrm{SiO} 2$ & 59.02 & 57.58 & 54.23 & 57.61 & 57.88 & 58.63 & 55.85 & 58.35 & 57.61 & 57.87 & 53.55 & 60.72 & 58.94 & 58.95 \\
\hline $\mathrm{TiO} 2$ & 0.37 & 0.23 & 1.81 & 0.32 & 0.23 & 0.31 & 1.01 & 0.51 & 0.96 & 0.81 & 1.84 & 0.63 & 0.38 & 0.47 \\
\hline $\mathrm{Al} 2 \mathrm{O} 3$ & 23.82 & 23.20 & 20.45 & 22.99 & 20.20 & 22.21 & 19.53 & 22.47 & 21.05 & 20.37 & 17.58 & 20.59 & 22.50 & 22.99 \\
\hline $\mathrm{Cr} 2 \mathrm{O} 3$ & 0.00 & 0.00 & 0.05 & 0.00 & 0.00 & 0.00 & 0.04 & 0.00 & 0.00 & 0.00 & 0.02 & 0.00 & 0.00 & 0.00 \\
\hline $\mathrm{FeO}$ & 1.51 & 1.31 & 2.58 & 1.21 & 0.61 & 1.15 & 2.48 & 1.14 & 1.84 & 1.59 & 3.30 & 1.34 & 1.27 & 1.33 \\
\hline $\mathrm{MnO}$ & 0.03 & 0.04 & 0.08 & 0.04 & 0.06 & 0.09 & 0.04 & 0.04 & 0.05 & 0.05 & 0.12 & 0.06 & 0.06 & 0.08 \\
\hline MgO & 0.31 & 0.35 & 2.87 & 0.32 & 0.00 & 0.28 & 2.73 & 0.48 & 1.33 & 1.30 & 4.50 & 0.94 & 0.34 & 0.28 \\
\hline $\mathrm{CaO}$ & 1.74 & 1.73 & 5.00 & 1.83 & 5.25 & 1.58 & 6.00 & 1.39 & 3.17 & 3.37 & 8.95 & 2.46 & 1.67 & 1.68 \\
\hline $\mathrm{Na} 2 \mathrm{O}$ & 7.59 & 6.82 & 6.98 & 7.33 & 5.73 & 6.71 & 5.88 & 7.40 & 6.68 & 5.85 & 5.01 & 6.80 & 6.99 & 7.37 \\
\hline $\mathrm{K} 2 \mathrm{O}$ & 5.16 & 5.23 & 4.35 & 6.37 & 6.44 & 6.78 & 4.29 & 7.02 & 5.13 & 6.58 & 3.44 & 5.16 & 6.02 & 5.66 \\
\hline $\mathrm{P} 2 \mathrm{O} 5$ & 1.37 & 1.21 & 0.74 & 1.32 & 1.90 & 1.32 & 0.99 & 0.72 & 0.94 & 0.80 & 0.84 & 0.95 & 1.54 & 0.91 \\
\hline $\mathrm{NiO}$ & 0.00 & 0.00 & 0.00 & 0.00 & 0.00 & 0.00 & 0.00 & 0.00 & 0.00 & 0.00 & 0.00 & 0.00 & 0.00 & 0.00 \\
\hline Total & 100.93 & 97.72 & 99.13 & 99.34 & 98.30 & 99.06 & 98.84 & 99.51 & 98.74 & 98.59 & 99.15 & 99.66 & 99.70 & 99.72 \\
\hline $\mathrm{Mg} \#$ & 0.31 & 0.37 & 0.71 & 0.37 & 0.00 & 0.35 & 0.71 & 0.48 & 0.62 & 0.64 & 0.75 & 0.61 & 0.37 & 0.32 \\
\hline
\end{tabular}


APPENDIX TABLE 1: Major element composition of melt inclusions

\begin{tabular}{|c|c|c|c|c|c|c|c|c|c|c|c|c|c|c|}
\hline MAG B 47 & $22(10 \mu)$ & $24(20 \mu)$ & $24(10 \mu)$ & $25(30 \mu)$ & $25(10 \mu)$ & $29(10 \mu)$ & $30(10 \mu)$ & $31(20 \mu)$ & $\mathrm{I} 31(30 \mu)$ & $34(10 \mu)$ & $36(10 \mu)$ & $37(30 \mu)$ & $41(20 \mu)$ & $42(10 \mu)$ \\
\hline $\mathrm{SiO} 2$ & 40.82 & 47.71 & 60.26 & 43.87 & 48.16 & 53.44 & 43.98 & 50.29 & 50.52 & 57.97 & 51.01 & 35.85 & 43.64 & 62.15 \\
\hline $\mathrm{TiO} 2$ & 0.06 & 0.38 & 0.36 & 0.00 & 0.02 & 1.17 & 0.00 & 2.09 & 2.85 & 0.11 & 0.23 & 0.72 & 1.52 & 0.09 \\
\hline $\mathrm{Al} 2 \mathrm{O} 3$ & 2.79 & 28.65 & 19.61 & 0.76 & 1.10 & 21.14 & 0.78 & 18.79 & 19.48 & 24.35 & 29.40 & 6.18 & 13.10 & 23.27 \\
\hline $\mathrm{Cr} 2 \mathrm{O} 3$ & 0.00 & 0.00 & 0.00 & 0.00 & 0.01 & 0.01 & 0.00 & 0.06 & 0.05 & 0.00 & 0.00 & 0.02 & 0.06 & 0.04 \\
\hline $\mathrm{FeO}$ & 3.96 & 1.20 & 2.47 & 5.58 & 16.32 & 2.50 & 4.79 & 4.60 & 5.33 & 0.95 & 0.61 & 5.47 & 7.52 & 0.78 \\
\hline $\mathrm{MnO}$ & 0.27 & 0.03 & 0.03 & 0.08 & 0.14 & 0.03 & 0.07 & 0.08 & 0.13 & 0.00 & 0.00 & 0.17 & 0.19 & 0.00 \\
\hline $\mathrm{MgO}$ & 36.53 & 0.37 & 1.94 & 30.55 & 21.23 & 2.91 & 34.26 & 2.06 & 2.83 & 0.00 & 0.00 & 23.79 & 8.66 & 0.00 \\
\hline $\mathrm{CaO}$ & 1.05 & 6.62 & 5.47 & 0.13 & 0.47 & 7.47 & 0.07 & 12.15 & 14.82 & 0.62 & 0.75 & 4.44 & 14.88 & 0.94 \\
\hline $\mathrm{Na} 2 \mathrm{O}$ & 0.00 & 13.15 & 3.00 & 0.00 & 0.07 & 11.00 & 0.00 & 4.75 & 4.90 & 10.25 & 15.77 & 0.00 & 0.43 & 11.22 \\
\hline $\mathrm{K} 2 \mathrm{O}$ & 0.00 & 1.70 & 7.45 & 0.00 & 0.12 & 0.95 & 0.00 & 0.78 & 0.45 & 4.68 & 2.34 & 0.00 & 1.42 & 2.48 \\
\hline $\mathrm{P} 2 \mathrm{O} 5$ & 1.03 & 2.97 & 0.41 & 0.33 & 0.40 & 1.02 & 0.19 & 0.25 & 0.83 & 0.06 & 0.00 & 0.57 & 0.40 & 0.01 \\
\hline $\mathrm{NiO}$ & 0.00 & 0.00 & 0.00 & 0.00 & 0.00 & 0.00 & 0.00 & 0.00 & 0.00 & 0.00 & 0.00 & 0.00 & 0.00 & 0.00 \\
\hline Total & 86.51 & 102.76 & 100.99 & 81.31 & 88.05 & 101.64 & 84.14 & 95.89 & 102.18 & 98.99 & 100.10 & 77.19 & 91.82 & 100.98 \\
\hline $\mathrm{Mg} \#$ & 0.95 & 0.41 & 0.63 & 0.92 & 0.74 & 0.66 & 0.94 & 0.50 & 0.54 & 0.00 & 0.00 & 0.91 & 0.72 & 0.00 \\
\hline MAG B 25 & $32(5 \mu)$ & $33(5 \mu)$ & $34(5 \mu)$ & $34(15 \mu)$ & $35(5 \mu)$ & $36(5 \mu)$ & $36(5 \mu)$ & $37(5 \mu)$ & $38(5 \mu)$ & $39(5 \mu)$ & $40(20 \mu)$ & $40 \mathrm{~A}(20 \mu)$ & $41(5 \mu)$ & $42(5 \mu)$ \\
\hline $\mathrm{SiO} 2$ & 46.93 & 41.58 & 62.71 & 52.19 & 50.63 & 50.81 & 50.16 & 60.90 & 51.85 & 48.62 & 51.60 & 50.55 & 59.35 & 60.06 \\
\hline $\mathrm{TiO} 2$ & 0.25 & 0.02 & 0.17 & 1.85 & 0.04 & 0.14 & 0.04 & 0.24 & 0.03 & 0.10 & 1.99 & 1.90 & 0.11 & 0.13 \\
\hline $\mathrm{Al} 2 \mathrm{O} 3$ & 6.72 & 10.67 & 23.78 & 17.88 & 19.69 & 19.53 & 20.61 & 19.25 & 18.73 & 19.43 & 16.87 & 17.25 & 21.79 & 21.15 \\
\hline $\mathrm{Cr} 2 \mathrm{O} 3$ & 0.03 & 0.00 & 0.00 & 0.00 & 0.01 & 0.03 & 0.01 & 0.00 & 0.02 & 0.00 & 0.06 & 0.02 & 0.01 & 0.00 \\
\hline $\mathrm{FeO}$ & 18.28 & 15.09 & 0.77 & 4.41 & 1.62 & 2.89 & 0.34 & 1.83 & 1.84 & 0.36 & 5.08 & 6.71 & 0.84 & 0.70 \\
\hline $\mathrm{MnO}$ & 0.00 & 0.00 & 0.05 & 0.00 & 0.00 & 0.00 & 0.00 & 0.00 & 0.00 & 0.00 & 0.16 & 0.00 & 0.00 & 0.00 \\
\hline $\mathrm{MgO}$ & 10.97 & 15.02 & 0.09 & 2.50 & 1.08 & 1.93 & 0.65 & 1.10 & 1.31 & 0.83 & 3.01 & 3.48 & 0.04 & 0.03 \\
\hline $\mathrm{CaO}$ & 3.39 & 0.99 & 1.80 & 9.16 & 8.22 & 3.69 & 10.07 & 3.12 & 7.58 & 10.89 & 8.99 & 6.83 & 3.66 & 3.69 \\
\hline $\mathrm{Na} 2 \mathrm{O}$ & 0.08 & 0.06 & 3.79 & 4.96 & 0.19 & 6.28 & 0.06 & 7.80 & 1.44 & 0.11 & 6.67 & 5.36 & 8.33 & 7.99 \\
\hline $\mathrm{K} 2 \mathrm{O}$ & 0.65 & 0.15 & 2.30 & 1.71 & 0.43 & 2.52 & 0.11 & 2.59 & 2.26 & 0.65 . & 1.72 & 2,96 & 2.13 & 2.22 \\
\hline P2O5 & 1.70 & 0.09 & 0.02 & 0.82 & 0.36 & 0.38 & 1.07 & 0.55 & 0.32 & 2.40 & 0.85 & 0.79 & 1.35 & 1.18 \\
\hline $\mathrm{NiO}$ & 0.00 & 0.00 & 0.00 & 0.00 & 0.00 & 0.00 & 0.00 & 0.00 & 0.00 & 0.00 & 0.00 & 0.00 & 0.00 & 0.00 \\
\hline Total & 89.00 & 83.66 & 95.48 & 95.48 & 82.26 & 88.20 & 83.13 & 97.38 & 85.37 & 83.39 & 96.99 & 95.84 & 97.60 & 97.15 \\
\hline $\mathrm{Mg \#}$ & 0.57 & 0.69 & 0.21 & 0.56 & 0.69 & 0.60 & 0.81 & 0.57 & 0.61 & 0.83 & 0.57 & 0.53 & 0.09 & 0.09 \\
\hline TAAB 26 & $34(20 \mu)$ & $35(30 \mu)$ & $36(30 \mu)$ & $37(20 \mu)$ & $38(20 \mu)$ & $40(30 \mu)$ & $41(30 \mu)$ & $43(10 \mu)$ & $48(10 \mu)$ & $48(10 \mu)$ & $49(30 \mu)$ & $50(30 \mu)$ & $51(30 \mu)$ & $52(10 \mu)$ \\
\hline $\mathrm{SiO} 2$ & 58.19 & 57.37 & 52.61 & 58.64 & 53.94 & 55.23 & 50.03 & 58.10 & 54.56 & 53.80 & 57.66 & 53.88 & 57.47 & 58.26 \\
\hline $\mathrm{TiO2}$ & 0.48 & 1.00 & 1.93 & 0.54 & 1.91 & 1.86 & 3.34 & 0.28 & 2.12 & 2.42 & 1.74 & 1.51 & 0.47 & 0.39 \\
\hline $\mathrm{Al} 2 \mathrm{O} 3$ & 22.35 & 21.21 & 19.66 & 21.17 & 20.20 & 19.29 & 19.04 & 20.86 & 20.34 & 20.71 & 19.11 & 18.48 & 22.41 & 21.77 \\
\hline $\mathrm{Cr} 2 \mathrm{O} 3$ & 0.00 & 0.00 & 0.00 & 0.00 & 0.00 & 0.00 & 0.00 & 0.00 & 0.00 & 0.00 & 0.00 & 0.00 & 0.00 & 0.00 \\
\hline $\mathrm{FeO}$ & 1.09 & 2.21 & 3.05 & 1.39 & 3.16 & 3.13 & 4.18 & 1.68 & 2.78 & 3.31 & 1.98 & 3.17 & 1.05 & 1.29 \\
\hline $\mathrm{MnO}$ & 0.06 & 0.07 & 0.06 & 0.03 & 0.12 & 0.10 & 0.06 & 0.04 & 0.09 & 0.04 & 0.04 & 0.09 & 0.05 & 0.05 \\
\hline $\mathrm{MgO}$ & 0.31 & 0.81 & 3.68 & 0.69 & 3.18 & 1.88 & 4.28 & 0.03 & 4.20 & 3.65 & 0.38 & 1.21 & 0.28 & 0.08 \\
\hline $\mathrm{CaO}$ & 2.38 & 4.07 & 6.15 & 2.10 & 5.31 & 6.58 & 7.12 & 1.95 & 4.98 & 5.05 & 6.99 & 8.82 & 2.08 & 2.37 \\
\hline $\mathrm{Na} 2 \mathrm{O}$ & 7.15 & 6.85 & 5.16 & 6.14 & 5.46 & 6.02 & 4.54 & 7.13 & 2.49 & 4.13 & 5.07 & 6.07 & 6.35 & 6.85 \\
\hline $\mathrm{K} 2 \mathrm{O}$ & 5.58 & 5.03 & 4.84 & 6.68 & 5.28 & 4.07 & 4.87 & 7.38 & 2.30 & 3.64 & 5.41 & 3.95 & 6.91 & 6.62 \\
\hline $\mathrm{P} 205$ & 1.12 & 0.38 & 0.52 & 0.94 & 0.77 & 1.10 & 1.14 & 1.22 & 0.83 & 0.86 & 1.15 & 0.87 & 1.24 & 0.85 \\
\hline $\mathrm{NiO}$ & 0.00 & 0.00 & 0.00 & 0.00 & 0.00 & 0.00 & 0.00 & 0.00 & 0.00 & 0.00 & 0.00 & 0.00 & 0.00 & 0.00 \\
\hline Total & 98.72 & 98.99 & 97.65 & 98.32 & 99.33 & 99.26 & 98.58 & 98.67 & 94.70 & 97.62 & 99.51 & 98.05 & 98.32 & 98.52 \\
\hline $\mathrm{Mg} \#$ & 0.38 & 0.45 & 0.73 & 0.52 & 0.69 & 0.57 & 0.69 & 0.03 & 0.77 & 0.71 & 0.30 & 0.46 & 0.37 & 0.12 \\
\hline
\end{tabular}


APPENDIX TABLE 1: Major element composition of melt inclusions

\begin{tabular}{|c|c|c|c|c|c|c|c|c|c|c|c|c|c|c|}
\hline MAG B 47 & $42(30 \mu)$ & $45 \mathrm{~A}(10 \mu)$ & $48(10 \mu)$ & $51(10 \mu)$ & $51 \mathrm{~A}(10 \mu)$ & $53(10 \mu)$ & $54(10 \mu)$ & $56(10 \mu)$ & $57(10 \mu)$ & $58(10 \mu)$ & $59(5 \mu)$ & $60(10 \mu)$ & $61(10 \mu)$ & $62(15 \mu)$ \\
\hline $\mathrm{SiO} 2$ & 52.96 & 51.75 & 45.44 & 49.76 & 43.86 & 36.88 & 37.32 & 47.70 & 40.46 & 50.58 & 46.58 & 43.04 & 52.24 & 39.97 \\
\hline $\mathrm{TiO} 2$ & 1.40 & 0.07 & 0.10 & 0.10 & 4.11 & 0.11 & 0.06 & 0.37 & 2.45 & 1.79 & 0.08 & 1.76 & 0.22 & 3.26 \\
\hline $\mathrm{Al} 2 \mathrm{O} 3$ & 20.36 & 29.79 & 12.56 & 27.69 & 13.11 & 9.99 & 9.39 & 7.30 & 9.89 & 18.74 & 10.47 & 15.26 & 1.56 & 8.24 \\
\hline $\mathrm{Cr} 2 \mathrm{O} 3$ & 0.06 & 0.00 & 0.00 & 0.01 & 0.10 & 0.02 & 0.01 & 0.00 & 0.00 & 0.03 & 0.02 & 0.06 & 0.00 & 0.03 \\
\hline $\mathrm{FeO}$ & 2.96 & 0.69 & 9.73 & 1.74 & 9.81 & 19.03 & 12.57 & 3.22 & 7.83 & 2.22 & 15.97 & 6.78 & 17.17 & 8.49 \\
\hline $\mathrm{MnO}$ & 0.10 & 0.00 & 0.16 & 0.01 & 0.12 & 0.23 & 0.14 & 0.05 & 0.08 & 0.00 & 0.56 & 0.04 & 0.17 & 0.36 \\
\hline $\mathrm{MgO}$ & 1.48 & 0.06 & 14.76 & 1.28 & 17.30 & 21.24 & 24.25 & 23.14 & 12.14 & 4.67 & 9.86 & 5.69 & 12.99 & 14.09 \\
\hline $\mathrm{CaO}$ & 7.24 & 0.09 & 2.43 & 1.40 & 0.06 & 0.71 & 0.41 & 1.86 & 11.13 & 9.09 & 0.56 & 9.83 & 1.07 & 15.36 \\
\hline $\mathrm{Na} 2 \mathrm{O}$ & 8.60 & 16.94 & 0.07 & 15.34 & 0.80 & 0.16 & 0.15 & 0.34 & 0.85 & 8.02 & 0.19 & 0.59 & 0.10 & 0.60 \\
\hline $\mathrm{K} 2 \mathrm{O}$ & 1.95 & 2.04 & 0.53 & 2.01 & 8.46 & 0.06 & 0.14 & 0.32 & 0.22 & 1.48 & 0.70 & 0.16 & 0.05 & 0.01 \\
\hline $\mathrm{P} 205$ & 1.17 & 0.05 & 0.00 & 0.98 & 0.11 & 0.06 & 0.00 & 0.11 & 0.27 & 0.36 & 0.09 & 0.11 & 0.05 & 0.24 \\
\hline $\mathrm{NiO}$ & 0.00 & 0.00 & 0.00 & 0.00 & 0.00 & 0.00 & 0.00 & 0.00 & 0.00 & 0.00 & 0.00 & 0.00 & 0.00 & 0.00 \\
\hline Total & 98.28 & 101.48 & 85.78 & 100.32 & 97.84 & 88.48 & 84.44 & 84.40 & 85.33 & 96.97 & 85.07 & 83.31 & 85.63 & 90.66 \\
\hline $\mathrm{Mg \#}$ & 0.53 & 0.16 & 0.76 & 0.62 & 0.80 & 0.71 & 0.80 & 0.94 & 0.77 & 0.82 & 0.58 & 0.65 & 0.62 & 0.79 \\
\hline MAG B 25 & $43(20 \mu)$ & $43(10 \mu)$ & $44(10 \mu)$ & $45(5 \mu)$ & $46(20 \mu)$ & $47(15 \mu)$ & $48(20 \mu)$ & $49(20 \mu)$ & $50(10 \mu)$ & $52(10 \mu)$ & $53(10 \mu)$ & $53(10 \mu)$ & $54(10 \mu)$ & $55(10 \mu)$ \\
\hline $\mathrm{SiO} 2$ & 47.84 & 46.91 & 59.22 & 58.24 & 42.66 & 45.96 & 46.89 & 42.88 & 57.90 & 58.35 & 52.18 & 49.15 & 48.44 & 26.98 \\
\hline $\mathrm{TiO} 2$ & 2.82 & 0.03 & 0.13 & 0.13 & 2.38 & 2.96 & 2.91 & 2.07 & 0.06 & 0.56 & 0.07 & 0.07 & 0.10 & 0.00 \\
\hline $\mathrm{Al} 2 \mathrm{O} 3$ & 14.23 & 10.45 & 21.01 & 21.83 & 18.12 & 16.72 & 14.97 & 11.45 & 5.11 & 21.16 & 8.19 & 2.52 & 0.91 & 2.94 \\
\hline $\mathrm{Cr} 2 \mathrm{O} 3$ & 0.03 & 0.03 & 0.00 & 0.00 & 0.02 & 0.06 & 0.09 & 0.04 & 0.00 & 0.00 & 0.03 & 0.06 & 0.05 & 0.09 \\
\hline $\mathrm{FeO}$ & 7.64 & 12.13 & 0.59 & 0.83 & 7.30 & 8.18 & 6.56 & 7.91 & 11.23 & 1.54 & 10.03 & 21.31 & 16.20 & 11.34 \\
\hline $\mathrm{MnO}$ & 0.00 & 0.01 & 0.00 & 0.00 & 0.00 & 0.00 & 0.00 & 0.04 & 0.00 & 0.00 & 0.00 & 0.00 & 0.00 & 0.01 \\
\hline $\mathrm{MgO}$ & 6.70 & 20.72 & 0.05 & 0.02 & 4.54 & 5.36 & 3.37 & 6.87 & 13.18 & 0.42 & 6.81 & 11.57 & 16.15 & 11.84 \\
\hline $\mathrm{CaO}$ & 12.73 & 0.66 & 2.99 & 3.77 & 9.30 & 10.07 & 12.80 & 11.84 & 1.44 & 4.07 & 5.73 & 1.30 & 2.20 & 6.45 \\
\hline $\mathrm{Na} 2 \mathrm{O}$ & 4.25 & 4.46 & 7.96 & 8.02 & 4.68 & 4.91 & 5.05 & 4.27 & 0.18 & 7.42 & 1.04 & 0.07 & 0.12 & 0.09 \\
\hline $\mathrm{K} 2 \mathrm{O}$ & $1.1 \mathrm{I}$ & 1.40 & 2.18 & 2.13 & 1.05 & 1.23 & 1.14 & 0.84 & 0.64 & 2,19 & 0.85 & 0.31 & 0.24 & 0.13 \\
\hline $\mathrm{P} 2 \mathrm{O} 5$ & 0.56 & 0.38 & 0.49 & 1.22 & 0.38 & 0.65 & 1.30 & 0.32 & 0.10 & 0.28 & 3.20 & 0.09 & 0.11 & 0.16 \\
\hline $\mathrm{NiO}$ & 0.00 & 0.00 & 0.00 & 0.00 & 0.00 & 0.00 & 0.00 & 0.00 & 0.00 & 0.00 & 0.00 & 0.00 & 0.00 & 0.00 \\
\hline Total & 97.91 & 97.17 & 94.63 & 96.19 & 90.43 & 96.08 & 95.07 & 88.52 & 89.85 & 95.98 & 88.13 & 86.45 & 84.52 & 60.03 \\
\hline $\mathrm{Mg} \#$ & 0.66 & 0.79 & 0.15 & 0.06 & 0.58 & 0.59 & 0.53 & 0.66 & 0.72 & 0.26 & 0.60 & 0.55 & 0.68 & 0.70 \\
\hline TAAB 26 & $52(20 \mu)$ & $53(20 \mu)$ & $54(30 \mu)$ & $55(20 \mu)$ & $59(10 \mu)$ & $59(30 \mu)$ & $60(30 \mu)$ & $61(30 \mu)$ & $62 \mathrm{~A}(30 \mu)$ & $63(30 \mu)$ & $66(20 \mu)$ & $67(10 \mu)$ & $68(30 \mu)$ & \\
\hline $\mathrm{SiO} 2$ & 52.65 & 59.14 & 52.34 & 57.79 & 60.88 & 58.21 & 57.44 & 58.14 & 58.66 & 57.51 & 56.61 & 56.87 & 57.55 & \\
\hline $\mathrm{TiO} 2$ & 1.83 & 0.40 & 2.48 & 1.78 & 0.22 & 1.06 & 0.45 & 0.47 & 0.27 & 0.48 & 0.39 & 0.69 & 0.77 & \\
\hline $\mathrm{Al} 2 \mathrm{O} 3$ & 20.78 & 22.15 & 19.05 & 19.51 & 22.10 & 21.14 & 21.94 & 21.55 & 21.31 & 21.53 & 23.11 & 22.76 & 20.41 & \\
\hline $\mathrm{Cr} 2 \mathrm{O} 3$ & 0.00 & 0.00 & 0.00 & 0.00 & 0.00 & 0.00 & 0.00 & 0.00 & 0.00 & 0.00 & 0.00 & 0.00 & 0.00 & \\
\hline $\mathrm{FeO}$ & 3.74 & 1.14 & 3.75 & 1.34 & 1.16 & 2.00 & 1.27 & 0.93 & 1.91 & 1.01 & 1.24 & 1.28 & 1.72 & \\
\hline $\mathrm{MnO}$ & 0.07 & 0.03 & 0.10 & 0.03 & 0.03 & 0.08 & 0.07 & 0.08 & 0.08 & 0.05 & 0.04 & 0.05 & 0.04 & \\
\hline $\mathrm{MgO}$ & 1.84 & 0.38 & 4.09 & 0.32 & 0.20 & 1.02 & 0.35 & 0.45 & 0.30 & 0.20 & 0.43 & 0.55 & 0.45 & \\
\hline $\mathrm{CaO}$ & 8.84 & 1.45 & 6.58 & 4.22 & 1.67 & 2.55 & 1.68 & 1.87 & 1.48 & 2.97 & 2.35 & 2.87 & 5.47 & \\
\hline $\mathrm{Na} 2 \mathrm{O}$ & 4.47 & 6.58 & 4.93 & 8.00 & 7.31 & 6.80 & 7.40 & 6.31 & 6.36 & 7.12 & 6.69 & 7.39 & 6.31 & \\
\hline $\mathrm{K} 2 \mathrm{O}$ & 4.63 & 6.65 & 4.88 & 5.01 & 5.90 & 5.39 & 7.39 & 6.97 & 7.06 & 6.20 & 6.23 & 4.74 & 5.25 & \\
\hline $\mathrm{P} 2 \mathrm{O} 5$ & 0.83 & 0.70 & 0.85 & 0.75 & 0.69 & 0.55 & 0.67 & 1.22 & 1.06 & 1.79 & 1.55 & 1.50 & 0.86 & \\
\hline $\mathrm{NiO}$ & 0.00 & 0.00 & 0.00 & 0.00 & 0.00 & 0.00 & 0.00 & 0.00 & 0.00 & 0.00 & 0.00 & 0.00 & 0.00 & \\
\hline Total & 99.68 & 98.61 & 99.04 & 98.74 & 100.15 & 98.79 & 98.65 & 98.00 & 98.48 & 98.85 & 98.65 & 98.69 & 98.81 & \\
\hline Mg\# & 0.52 & 0.43 & 0.71 & 0.35 & 0.27 & 0.53 & 0.38 & 0.52 & 0.25 & 0.31 & 0.44 & 0.49 & 0.36 & \\
\hline
\end{tabular}


APPENDIX TABLE 1: Major element composition of melt inclusions

\begin{tabular}{|c|c|c|c|c|c|c|c|c|c|}
\hline MAG B 47 & $64(5 \mu)$ & $65(15 \mu)$ & $66(15 \mu)$ & $67(5 \mu)$ & $67(15 \mu)$ & $68(10 \mu)$ & $71(5 \mu)$ & $72(10 \mu)$ & $73(5 \mu)$ \\
\hline $\mathrm{SiO} 2$ & 41.95 & 55.46 & 52.22 & 42.17 & 35.17 & 51.61 & 37.58 & 41.82 & 43.62 \\
\hline $\mathrm{TiO} 2$ & 1.46 & 1.82 & 2.52 & 0.04 & 2.82 & 2.27 & 0.08 & 0.04 & 0.02 \\
\hline $\mathrm{Al} 2 \mathrm{O} 3$ & 3.04 & 22.46 & 20.64 & 0.80 & 7.41 & 18.17 & 7.64 & 0.79 & 0.00 \\
\hline $\mathrm{Cr} 2 \mathrm{O} 3$ & 0.00 & 0.00 & 0.08 & 0.01 & 0.12 & 0.02 & 0.03 & 0.00 & 0.03 \\
\hline $\mathrm{FeO}$ & 10.06 & 3.18 & 3.85 & 9.93 & 7.98 & 3.13 & 16.02 & 7.33 & 12.45 \\
\hline $\mathrm{MnO}$ & 0.09 & 0.32 & 0.06 & 0.26 & 0.19 & 0.00 & 0.21 & 0.19 & 0.16 \\
\hline $\mathrm{MgO}$ & 28.06 & 2.56 & 3.78 & 28.49 & 17.97 & 6.22 & 20.91 & 33.85 & 27.44 \\
\hline $\mathrm{CaO}$ & 0.11 & 4.72 & 7.38 & 1.42 & 12.88 & 5.53 & 0.42 & 0.22 & 0.19 \\
\hline $\mathrm{Na} 2 \mathrm{O}$ & 0.16 & 4.27 & 4.50 & 0.00 & 0.38 & 4.70 & 0.06 & 0.00 & 0.03 \\
\hline $\mathrm{K} 2 \mathrm{O}$ & 1.40 & 2.22 & 2.07 & 0.00 & 0.32 & 5.67 & 0.15 & 0.00 & 0.02 \\
\hline P2O5 & 0.07 & 0.26 & 0.65 & 0.88 & 0.09 & 0.31 & 0.00 & 0.00 & 0.00 \\
\hline $\mathrm{NiO}$ & 0.00 & 0.00 & 0.00 & 0.00 & 0.00 & 0.00 & 0.00 & 0.00 & 0.00 \\
\hline Total & 86.40 & 97.26 & 97.75 & 84.00 & 85.33 & 97.62 & 83.08 & 84.25 & 83.96 \\
\hline $\mathrm{Mg} \#$ & 0.86 & 0.64 & 0.68 & 0.86 & 0.83 & 0.81 & 0.74 & 0.91 & 0.83 \\
\hline MAG B 25 & $56(10 \mu)$ & $56(10 \mu)$ & $56(10 \mu)$ & $57(10 \mu)$ & & & & & \\
\hline $\mathrm{SiO} 2$ & 49.71 & 52.31 & 59.30 & 49.84 & & & & & \\
\hline $\mathrm{TiO} 2$ & 0.43 & 0.07 & 0.12 & 0.26 & & & & & \\
\hline Al2O3 & 8.86 & 20.57 & 21.03 & 7.11 & & & & & \\
\hline $\mathrm{Cr} 2 \mathrm{O} 3$ & 0.04 & 0.00 & 0.00 & 0.00 & & & & & \\
\hline $\mathrm{FeO}$ & 16.33 & 1.24 & 0.87 & 15.18 & & & & & \\
\hline $\mathrm{MnO}$ & 0.00 & 0.00 & 0.00 & 0.00 & & & & & \\
\hline $\mathrm{MgO}$ & 10.81 & 0.86 & 0.04 & 9.86 & & & & & \\
\hline $\mathrm{CaO}$ & 2.22 & 7.79 & 2.38 & 1.79 & & & & & \\
\hline $\mathrm{Na} 2 \mathrm{O}$ & 0.13 & 0.37 & 7.98 & 0.98 & & & & & \\
\hline $\mathrm{K} 2 \mathrm{O}$ & 0.63 & 0.26 & 2.47 & 0.63 & & & & & \\
\hline $\mathrm{P} 2 \mathrm{O} 5$ & 0.17 & 0.22 & 0.65 & 0.29 & & & & & \\
\hline $\mathrm{NiO}$ & 0.00 & 0.00 & 0.00 & 0.00 & & & & & \\
\hline Total & 89.32 & 83.68 & 94.83 & 85.93 & & & & & \\
\hline Mg\# & 0.59 & 0.61 & 0.10 & 0.59 & & & & & \\
\hline
\end{tabular}




\section{APPENDIX TABLE 2: Major element compositions of host Olivines}

\begin{tabular}{|c|c|c|c|c|c|c|c|c|c|c|c|c|c|}
\hline$\overline{M A G ~ B ~} 47$ & OLIVINE 1 & OLIVINE 2 & OLIVINE 3 & OLIVINE 4 & OLIVINE 5 & OLIVINE 6-7 & OLIVINE 8 & OLIVINE 9 & OLIVINE 10 & OLIVINE 11 & OLIVINE 12- & 13 OLIVINE $12 \mathrm{NI}$ & OLIVINE 14 \\
\hline $\mathrm{SiO} 2$ & 39.85 & 39.51 & 39.13 & 39.68 & 38.82 & 39.83 & 39.93 & 39.55 & 39.99 & 38.94 & 38.69 & 38.37 & 40.07 \\
\hline $\mathrm{TiO} 2$ & 0.01 & 0.01 & 0.00 & 0.00 & 0.01 & 0.00 & 0.00 & 0.00 & 0.03 & 0.00 & 0.00 & 0.01 & 0.00 \\
\hline Al2O3 & 0.02 & 0.03 & 0.03 & 0.00 & 0.02 & 0.00 & 0.00 & 0.00 & 0.05 & 0.03 & 0.00 & 0.08 & 0.02 \\
\hline $\mathrm{Cr} 2 \mathrm{O} 3$ & 0.03 & 0.02 & 0.04 & 0.00 & 0.02 & 0.01 & 0.00 & 0.04 & 0.05 & 0.03 & 0.04 & 0.03 & 0.07 \\
\hline $\mathrm{FeO}$ & 13.11 & 13.01 & 15.02 & 14.03 & 17.32 & 15.44 & 14.58 & 13.16 & 13.58 & 13.09 & 17.21 & 23.52 & 12.83 \\
\hline $\mathrm{MnO}$ & 0.20 & 0.18 & 0.24 & 0.21 & 0.27 & 0.22 & 0.24 & 0.18 & 0.22 & 0.20 & 0.28 & 0.17 & 0.17 \\
\hline $\mathrm{MgO}$ & 47.24 & 46.65 & 45.30 & 46.49 & 44,45 & 45.45 & 45.98 & 47.22 & 46.03 & 47.09 & 43.55 & 10.81 & 47.33 \\
\hline $\mathrm{CaO}$ & 0.38 & 0.43 & 0.42 & 0.40 & 0.40 & 0.40 & 0.40 & 0.35 & 0.43 & 0.32 & 0.38 & 0.45 & 0.46 \\
\hline $\mathrm{Na} 2 \mathrm{O}$ & 0.00 & 0.00 & 0.00 & 0.00 & 0.00 & 0.00 & 0.00 & 0.00 & 0.00 & 0.00 & 0.00 & 0.00 & 0.00 \\
\hline $\mathrm{K} 2 \mathrm{O}$ & 0.00 & 0.00 & 0.00 & 0.00 & 0.00 & 0.00 & 0.00 & 0.00 & 0.00 & 0.00 & 0.00 & 0.00 & 0.00 \\
\hline P2OS & 0.00 & 0.00 & 0.00 & 0.00 & 0.00 & 0.00 & 0.00 & 0.00 & 0.00 & 0.00 & 0.00 & 0.00 & 0.00 \\
\hline NiO & 0.23 & 0.21 & 0.17 & 0.26 & 0.19 & 0.22 & 0.20 & 0.26 & 0.25 & 0.22 & 0.19 & 0.10 & 0.24 \\
\hline Total & 101.07 & 100.04 & 100.35 & 101.05 & 101.49 & 101.57 & 101.32 & 100.76 & 100.62 & 99.90 & 100.33 & 73.53 & 101.18 \\
\hline Mg\# & 0.89 & 0.89 & 0.87 & 0.88 & 0.85 & 0.87 & 0.87 & 0.89 & 0.88 & 0.89 & 0.85 & 0.50 & 0.89 \\
\hline
\end{tabular}

\begin{tabular}{|c|c|c|c|c|c|c|c|c|c|c|c|c|c|}
\hline MAG B 25 & OLIVINE NI 2 & OLIVINE 2 & OLIVINE NI 3 & OLIVINE 3 & OLIVINE NI 6 & OLIVINE 6-7 & OLIVINE NI13 & OLIVINE $12-13$ & OLIVINE NI14 & OLIVINE 14 & OLIVINE N15 & OLIVINE 15 & OLNVINE NI7 \\
\hline $\mathrm{SiO} 2$ & 38.55 & 38.21 & 38.30 & 38.58 & 38.75 & 38.41 & 38.39 & 38.56 & 38.73 & 38.92 & 38.04 & 38.61 & 39.02 \\
\hline $\mathrm{T} \mathrm{OO} 2$ & 0.00 & 0.02 & 0.00 & 0.05 & 0.00 & 0.01 & 0.00 & 0.00 & 0.02 & 0.02 & 0.03 & 0.00 & 0.04 \\
\hline $\mathrm{A} 2 \mathrm{O} 3$ & 0.05 & 0.02 & 0.04 & 0.04 & 0.04 & 0.04 & 0.06 & 0.04 & 0.03 & 0.00 & 0.04 & 0.03 & 0.05 \\
\hline $\mathrm{Cr} 2 \mathrm{O} 3$ & 0.00 & 0.00 & 0.00 & 0.04 & 0.01 & 0.04 & 0.02 & 0.09 & 0.05 & 0.04 & 0.06 & 0.03 & 0.05 \\
\hline $\mathrm{FeO}$ & 17.88 & 18.19 & 17.76 & 18.42 & 17.92 & 18.15 & 17.18 & 17.43 & 16.50 & 16.46 & 18.43 & 18.67 & 16.51 \\
\hline $\mathrm{MnO}$ & 0.25 & 0.26 & 0.30 & 0.26 & 0.27 & 0.09 & 0.08 & 0.09 & 0.04 & 0.07 & 0.14 & 0.09 & 0.06 \\
\hline $\mathrm{MgO}$ & 4320 & 43.10 & 43.08 & 43.01 & 42.84 & 42.88 & 43.07 & 43.04 & 43.63 & 43.96 & 42.80 & 42.22 & 44.72 \\
\hline $\mathrm{CaO}$ & 0.38 & 0.44 & 0.39 & 0.41 & 0.40 & $\begin{array}{l}42.0 \% \\
0.40\end{array}$ & 0.42 & $\begin{array}{l}3.34 \\
0.38\end{array}$ & 0.43 & 0.44 & 0.43 & 0.36 & 0.48 \\
\hline $\mathrm{Na} 2 \mathrm{O}$ & 0.00 & 0.00 & 0.00 & 0.00 & 0.00 & 0.00 & 0.00 & 0.00 & 0.00 & 0.00 & 0.00 & 0.00 & 0.00 \\
\hline $\mathrm{K} 2 \mathrm{O}$ & 0.00 & 0.00 & 0.00 & 0.00 & 0.00 & 0.00 & 0.00 & 0.00 & 0.00 & 0.00 & 0.00 & 0.00 & 0.00 \\
\hline $\mathrm{P} 205$ & 0.00 & 0.00 & 0.00 & 0.00 & 0.00 & 0.00 & 0.00 & 0.00 & 0.00 & 0.00 & 0.00 & 0.00 & 0.00 \\
\hline $\mathrm{NiO}$ & 0.15 & 0.16 & 0.17 & 0.17 & 0.18 & 0.03 & 0.04 & 0.02 & 0.04 & 0.05 & 0.03 & 0.04 & 0.05 \\
\hline Total & 100.45 & 100.39 & 100.03 & 100.98 & 100.41 & 100.07 & 99.27 & 99.65 & 99.45 & 99.97 & 100.00 & 100.03 & 100.99 \\
\hline Mg\# & 0.84 & 0.84 & 0.84 & $\begin{array}{c}0.84 \\
0.84\end{array}$ & 0.84 & 0.84 & 0.85 & $\begin{array}{l}0.85 \\
0.85\end{array}$ & 0.85 & 0.86 & 0.84 & 0.83 & 0.86 \\
\hline
\end{tabular}

\begin{tabular}{|c|c|c|c|c|c|c|c|c|c|c|c|c|c|}
\hline TAA B 26 & OLIVINE I & OLIVINE 3 & OLIVINE 4 & OLIVINE 5.6 & OLIVINE 7 & OLIVINE 8 & OLIVINE 9 & OLIVINE 10 & OLIVINE 12 & OLIVINE 14 & OLIVINE 17 & OLIVINE 18 & OLIVINE 20 \\
\hline $\mathrm{SiO} 2$ & 38.56 & 38.63 & 38.67 & 38.92 & 38.85 & 39.16 & 38.55 & 38.88 & 39.10 & 38.49 & 38.87 & 38.75 & 38.81 \\
\hline $\mathrm{TiO} 2$ & 0.05 & 0.04 & 0.06 & 0.04 & 0.00 & 0.00 & 0.03 & 0.00 & 0.03 & 0.02 & 0.03 & 0.00 & 0.03 \\
\hline Al2O3 & 0.05 & 0.04 & 0.04 & 0.05 & 0.05 & 0.06 & 0.06 & 0.04 & 0.07 & 0.06 & 0.05 & 0.05 & 0.04 \\
\hline $\mathrm{Cr} 2 \mathrm{O} 3$ & 0.00 & 0.00 & 0.00 & 0.03 & 0.05 & 0.05 & 0.05 & 0.02 & 0.02 & 0.01 & 0.04 & 0.00 & 0.01 \\
\hline $\mathrm{FeO}$ & 19.75 & 19.97 & 19.23 & 19.85 & 19.57 & 19.47 & 19.56 & 19.06 & 18.96 & 19.83 & 20.29 & 19.46 & 19.63 \\
\hline $\mathrm{MnO}$ & 0.25 & 0.27 & 0.25 & 0.27 & 0.25 & 0.26 & 0.26 & 0.25 & 0.22 & 0.24 & 0.26 & 0.25 & 0.25 \\
\hline $\mathrm{MgO}$ & 41.19 & 41.97 & 42.14 & 42,15 & 41.16 & 41.48 & $4 \mathrm{I} .5 \mathrm{I}$ & 43.07 & 41.65 & 41.03 & 41.01 & 41.57 & 41.60 \\
\hline $\mathrm{CaO}$ & 0.34 & 0.32 & 0.29 & 0.32 & 0.28 & 0.25 & 0.31 & 0.32 & 0.30 & 0.27 & 0.32 & 0.29 & 0.30 \\
\hline $\mathrm{Na} 2 \mathrm{O}$ & 0.00 & 0.00 & 0.00 & 0.00 & 0.00 & 0.00 & 0.00 & 0.00 & 0.00 & 0.00 & 0.00 & 0.00 & 0.00 \\
\hline $\mathrm{K} 2 \mathrm{O}$ & 0.00 & 0.00 & 0.00 & 0.00 & 0.00 & 0.00 & 0.00 & 0.00 & 0.00 & 0.00 & 0.00 & 0.00 & 0.00 \\
\hline $\mathrm{P} 205$ & 0.00 & 0.00 & 0.00 & 0.00 & 0.00 & 0.00 & 0.00 & 0.00 & 0.00 & 0.00 & 0.00 & 0.00 & 0.00 \\
\hline $\mathrm{NiO}$ & 0.18 & 0.13 & 0.19 & 0.17 & 0.22 & 0.22 & 0.20 & 0.25 & 0.25 & 0.20 & 0.18 & 0.21 & 0.23 \\
\hline Total & 100.37 & 101.38 & 100.86 & 101.79 & 100.43 & 100.94 & 100.53 & 101.87 & 100.58 & 100.16 & 101.05 & 100.58 & 100.90 \\
\hline Mg\# & 0.82 & 0.82 & 0.83 & 0.82 & 0.82 & 0.82 & 0.82 & 0.83 & 0.83 & 0.82 & 0.82 & 0.83 & 0.82 \\
\hline
\end{tabular}


APPENDIX TABLE 2: Major element compositions of host Olivines

\begin{tabular}{|c|c|c|c|c|c|c|c|c|c|c|c|c|c|}
\hline MAG B 47 & OLIVINE I5 & OLIVINE 16 & OLIVINE 17 & OLIVINE 18 & OLIVINE $19 \cdot 20$ & OLIVINE 21 & OLIVINE 22 & OLIVINE 23 & OLIVINE 24 & OLIVINE 25 & OLIVINE $26-27$ & OLIVINE 28 & OLIVINE 29-30 \\
\hline $\mathrm{SiO} 2$ & 39.25 & 39.95 & 39.36 & 39.45 & 39.43 & 38.69 & 39.24 & 38.92 & 38.55 & 39.46 & 39.48 & 40.10 & 39.95 \\
\hline $\mathrm{TiO} 2$ & 0.02 & 0.02 & 0.00 & 0.01 & 0.01 & 0.07 & 0.00 & 0.02 & 0.03 & 0.02 & 0.04 & 0.00 & 0.00 \\
\hline $\mathrm{A} 12 \mathrm{O} 3$ & 0.03 & 0.06 & 0.04 & 0.02 & 0.04 & 0.10 & 0.02 & 0.03 & 0.02 & 0.06 & 0.03 & 0.00 & 0.03 \\
\hline $\mathrm{Cr} 2 \mathrm{O} 3$ & 0.04 & 0.07 & 0.02 & 0.00 & 0.06 & 0.06 & 0.03 & 0.05 & 0.04 & 0.04 & 0.04 & 0.02 & 0.05 \\
\hline $\mathrm{FeO}$ & I5.36 & 13.13 & 13.15 & 17.93 & 14.50 & 22.60 & 15.16 & 18.09 & 17.82 & 14.90 & 15.12 & 14.62 & 13.32 \\
\hline $\mathrm{MnO}$ & 0.23 & 0.17 & 0.21 & 0.27 & 0.22 & 0.38 & 0.25 & 0.25 & 0.30 & 0.23 & 0.27 & 0.22 & 0.21 \\
\hline $\mathrm{MgO}$ & 45.86 & 47.01 & 48.58 & 42.90 & 45.63 & 38.25 & 45.29 & 43.62 & 44.11 & 46.66 & 46.45 & 45.57 & 47.15 \\
\hline $\mathrm{CaO}$ & 0.47 & 0.35 & 0.38 & 0.39 & 0.41 & 0.48 & 0.37 & 0.39 & 0.38 & 0.31 & 0.38 & 0.43 & 0.42 \\
\hline $\mathrm{Na} 2 \mathrm{O}$ & 0.00 & 0.00 & 0.00 & 0.00 & 0.00 & 0.00 & 0.00 & 0.00 & 0.00 & 0.00 & 0.00 & 0.00 & 0.00 \\
\hline $\mathrm{K} 2 \mathrm{O}$ & 0.00 & 0.00 & 0.00 & 0.00 & 0.00 & 0.00 & 0.00 & 0.00 & 0.00 & 0.00 & 0.00 & 0.00 & 0.00 \\
\hline $\mathrm{P} 2 \mathrm{O} 5$ & 0.00 & 0.00 & 0.00 & 0.00 & 0.00 & 0.00 & 0.00 & 0.00 & 0.00 & 0.00 & 0.00 & 0.00 & 0.00 \\
\hline $\mathrm{NiO}$ & 0.23 & 0.21 & 0.27 & 0.20 & 0.21 & 0.18 & 0.24 & 0.23 & 0.21 & 0.19 & 0.24 & 0.22 & 0.24 \\
\hline Total & 101.50 & 100.96 & 102.01 & 301.18 & 100.51 & 100.81 & 100.59 & 101.59 & 101.46 & 101.85 & 102.04 & 101.18 & 101.36 \\
\hline Mg\# & 0.87 & 0.89 & 0.89 & 0.84 & 0.87 & 0.79 & 0.87 & 0.84 & 0.85 & 0.87 & 0.87 & 0.87 & 0.89 \\
\hline
\end{tabular}

\begin{tabular}{|c|c|c|c|c|c|c|c|c|c|c|c|c|c|}
\hline MAG B 25 & OLIVINE 17 & OLIVINE NI 34 & OLIVINE 34 & OLIVINE N137 & OLIVINE 37 & OLIVINE NI40 & OLIVINE 40 & OLIVINE NI43 & OLIVINE 43 & OLIVINE NI 4 & 7 OLIVINE $46-47$ & OLIVINE NI48 & OLIVINE 48 \\
\hline $\mathrm{SiO} 2$ & 39.19 & 39.17 & 38.74 & 39.44 & 38.91 & 38.90 & 38.63 & 38.94 & 38.00 & 37.96 & 38.35 & 38.82 & 38.95 \\
\hline TiO2 & 0.00 & 0.02 & 0.03 & 0.03 & 0.02 & 0.05 & 0.02 & 0.05 & 0.00 & 0.03 & 0.03 & 0.00 & 0.00 \\
\hline $\mathrm{A} 12 \mathrm{O} 3$ & 0.03 & 0.04 & 0.02 & 0.03 & 0.02 & 0.03 & .0 .00 & 0.03 & 1.01 & 0.03 & 0.05 & 0.04 & 0.03 \\
\hline $\mathrm{Cr} 2 \mathrm{O} 3$ & 0.06 & 0.08 & 0.04 & 0.04 & 0.03 & 0.00 & 0.04 & 0.02 & 0.04 & 0.04 & 0.03 & 0.06 & 0.02 \\
\hline $\mathrm{FeO}$ & 16.37 & 16.96 & 16.80 & 17.76 & 18.01 & 17,90 & 17.90 & 17.80 & 17.08 & 18.13 & 18.10 & 16.98 & 17.20 \\
\hline $\mathrm{MnO}$ & 0.05 & 0.25 & 0.26 & 0.25 & 0.23 & 0.20 & 0.26 & 0.29 & 0.24 & 0.22 & 0.26 & 0.23 & 0.22 \\
\hline $\mathrm{MgO}$ & 44.09 & 42,86 & 43.74 & 41.97 & 42.74 & 42.95 & 43.28 & 42.16 & 42.16 & 43.36 & 43.11 & 43.42 & 43.61 \\
\hline $\mathrm{CaO}$ & 0.37 & 0.41 & 0.36 & 0.44 & 0.41 & 0.46 & 0.43 & 0.51 & 0.40 & 0.41 & 0.40 & 0.47 & 0.38 \\
\hline $\mathrm{Na} 2 \mathrm{O}$ & 0.00 & 0.00 & 0.00 & 0.00 & 0.00 & 0.00 & 0.00 & 0.00 & 0.00 & 0.00 & 0.00 & 0.00 & 0.00 \\
\hline $\mathrm{K} 2 \mathrm{O}$ & 0.00 & 0.00 & 0.00 & 0.00 & 0.00 & 0.00 & 0.00 & 0.00 & 0.00 & 0.00 & 0.00 & 0.00 & 0.00 \\
\hline P2O5 & 0.00 & 0.00 & 0.00 & 0.00 & 0.00 & 0.00 & 0.00 & 0.00 & 0.00 & 0.00 & 0.00 & 0.00 & 0.00 \\
\hline NiO & 0.03 & 0.20 & 0.19 & 0.15 & 0.15 & 0.15 & 0.18 & 0.17 & 0.15 & 0.15 & 0.14 & 0.17 & 0.19 \\
\hline Total & 100.18 & 99.99 & 100.18 & 100.10 & 100.52 & 100.64 & 100.74 & 99.95 & 99.07 & 100.32 & 100.47 & 100.19 & 100.60 \\
\hline $\mathrm{Mg \#}$ & 0.86 & 0.85 & 0.85 & 0.84 & 0.84 & 0.84 & 0.84 & 0.84 & 0.85 & 0.84 & 0.84 & 0.85 & 0.85 \\
\hline
\end{tabular}

\begin{tabular}{|c|c|c|c|c|c|c|c|c|c|c|c|c|c|}
\hline TAA B 26 & OLIVINE 21 & OLIVINE 22 & OLIVINE 23 & OLIVINE 24 & OLIVINE 25 & OLIVINE 28 & OLIVINE 30 & OLIVINE 32 & OLIVINE 35 & OLIVINE 37 & OLIVINE 40 & OLIVINE NI 41 & OLIVINE 41 \\
\hline $\mathrm{SiO}_{2}$ & 38.46 & 38.64 & 38.83 & 38.59 & 38.56 & 38.43 & 38.44 & 38.60 & 38.44 & 38.83 & 38.61 & 38.26 & 38.70 \\
\hline $\mathrm{TiO} 2$ & 0.00 & 0.03 & 0.02 & 0.05 & 0.00 & 0.03 & 0.00 & 0.02 & 0.00 & 0.00 & 0.01 & 0.02 & 0.01 \\
\hline $\mathrm{Al} 2 \mathrm{O} 3$ & 0.05 & 0.06 & 0.06 & 0.05 & 0.06 & 0.05 & 0.04 & 0.05 & 0.04 & 0.05 & 0.05 & 0.07 & 0.02 \\
\hline $\mathrm{Cr} 2 \mathrm{O} 3$ & 0.07 & 0.00 & 0.02 & 0.02 & 0.00 & 0.04 & 0.04 & 0.03 & 0.02 & 0.01 & 0.00 & 0.04 & 0.00 \\
\hline $\mathrm{FeO}$ & 19.45 & 19.46 & 19.65 & 19.43 & 19.83 & 19.71 & 19.66 & 19.46 & 18.94 & 19.60 & 19.60 & 19.83 & 19.48 \\
\hline $\mathrm{MnO}$ & 0.28 & 0.25 & 0.25 & 0.26 & 0.26 & 0.26 & 0.29 & 0.25 & 0.22 & 0.23 & 0.25 & 0.25 & 0.30 \\
\hline $\mathrm{MgO}$ & 41.49 & 41.94 & 41.49 & 41.74 & 41.18 & 41.51 & 41.95 & 41.63 & 42.79 & 41.75 & 41.40 & 41.45 & 40.94 \\
\hline $\mathrm{CaO}$ & 0.30 & 0.28 & 0.35 & 0.32 & 0.29 & 0.31 & 0.29 & 0.29 & 0.28 & 0.30 & 0.29 & 0.30 & 0.30 \\
\hline $\mathrm{Na} 2 \mathrm{O}$ & 0.00 & 0.00 & 0.00 & 0.00 & 0.00 & 0.00 & 0.00 & 0.00 & 0.00 & 0.00 & 0.00 & 0.00 & 0.00 \\
\hline $\mathrm{K} 2 \mathrm{O}$ & 0.00 & 0.00 & 0.00 & 0.00 & 0.00 & 0.00 & 0.00 & 0.00 & 0.00 & 0.00 & 0.00 & 0.00 & 0.00 \\
\hline $\mathrm{P} 2 \mathrm{O} 5$ & 0.00 & 0.00 & 0.00 & 0.00 & 0.00 & 0.00 & 0.00 & 0.00 & 0.00 & 0.00 & 0.00 & 0.00 & 0.00 \\
\hline $\mathrm{NiO}$ & 0.23 & 0.21 & 0.18 & 0.19 & 0.18 & 0.18 & 0.17 & 0.21 & 0.23 & 0.18 & 0.20 & 0.19 & 0.19 \\
\hline Total & 100.33 & 100.85 & 100.86 & 100.64 & 100.36 & 100.52 & 100.88 & 100.55 & 100.95 & 100.94 & 100.41 & 100.41 & 99.93 \\
\hline Mg\# & 0.83 & 0.83 & 0.82 & 0.83 & 0.82 & 0.82 & 0.83 & 0.83 & 0.83 & 0.82 & 0.82 & 0.82 & 0.82 \\
\hline
\end{tabular}


APPENDIX TABLE 2: Major element compositions of host Olivines

\begin{tabular}{|c|c|c|c|c|c|c|c|c|c|c|c|c|c|}
\hline MAG B 47 & OLIVINE 31 & OLIVINE 32 & OLIVINE 33 & OLIVINE 33 & OLIVINE 34 & OLIVINE 35.36 & OLIVINE 37 & OLIVINE 38 & OLIVINE 39 & OLIVINE 40 & OLIVINE 41 & OLIVINE $42-4$ & 3 OLIVINE 44.45 \\
\hline $\mathrm{SiO} 2$ & 39.19 & 39.21 & 38.98 & 36.62 & 39.84 & 39.45 & 39.62 & 39.77 & 39.93 & 39.57 & 39.65 & 39.27 & 38.24 \\
\hline $\mathrm{TiO} 2$ & 0.00 & 0.00 & 0.01 & 0.06 & 0.00 & 0.03 & 0.00 & 0.03 & 0.00 & 0.00 & 0.00 & 0.02 & 0.05 \\
\hline $\mathrm{Al} 2 \mathrm{O} 3$ & 0.04 & 0.03 & 0.03 & 0.18 & 0.00 & 0.03 & 0.02 & 0.04 & 0.00 & 0.02 & 0.00 & 0.03 & 0.03 \\
\hline $\mathrm{Cr} 2 \mathrm{O} 3$ & 0.04 & 0.06 & 0.03 & 0.06 & 0.06 & 0.05 & 0.03 & 0.05 & 0.03 & 0.04 & 0.00 & 0.00 & 0.00 \\
\hline $\mathrm{FeO}$ & 15.40 & 14.88 & 16.09 & 15.24 & 12.94 & 14.97 & 15.05 & 13.39 & 13.13 & 14.90 & 17.38 & 15.79 & 18.80 \\
\hline $\mathrm{MnO}$ & 0.24 & 0.23 & 0.23 & 0.28 & 0.19 & 0.26 & 0.22 & 0.22 & 0.20 & 0.21 & 0.26 & 0.22 & 0.29 \\
\hline MgO & 46.36 & 45.61 & 43.35 & 41.33 & 47.04 & 45.28 & 45.92 & 47.66 & 47.33 & 45.49 & 43.53 & 44.40 & 41.03 \\
\hline $\mathrm{CaO}$ & 0.41 & 0.42 & 0.37 & 0.54 & 0.39 & 0.43 & 0.39 & 0.42 & 0.43 & 0.44 & 0.35 & 0.39 & 0.44 \\
\hline $\mathrm{Na} 2 \mathrm{O}$ & 0.00 & 0.00 & 0.00 & 0.00 & 0.00 & 0.00 & 0.00 & 0.00 & 0.00 & 0.00 & 0.00 & 0.00 & 0.00 \\
\hline $\mathrm{K} 2 \mathrm{O}$ & 0.00 & 0.00 & 0.00 & 0.00 & 0.00 & 0.00 & 0.00 & 0.00 & 0.00 & 0.00 & 0.00 & 0.00 & 0.00 \\
\hline P2O5 & 0.00 & 0.00 & 0.00 & 0.00 & 0.00 & 0.00 & 0.00 & 0.00 & 0.00 & 0.00 & 0.00 & 0.00 & 0.00 \\
\hline NiO & 0.23 & 0.17 & 0.22 & 0.21 & 0.24 & 0.21 & 0.22 & 0.27 & 0.22 & 0.21 & 0.20 & 0.20 & 0.19 \\
\hline Total & 101.91 & 100.62 & 99.30 & 94.52 & 100.71 & 100.71 & 101.47 & 101.84 & 101.25 & 100.87 & 101.36 & 100.33 & 99.07 \\
\hline Mg\# & 0.87 & 0.87 & 0.86 & 0.86 & 0.89 & 0.87 & 0.87 & 0.89 & 0.89 & 0.87 & 0.85 & 0.86 & 0.83 \\
\hline
\end{tabular}

\begin{tabular}{|c|c|c|c|c|c|c|c|}
\hline MAG B 25 & TOLIVINE NI49 & OLIVINE 49 & OLIVINE NI52 & OLIVINE 52 & OLIVINE NI53 & OLIVINE 53 & OLIVINE NIS4 \\
\hline $\mathrm{SiO} 2$ & 38.69 & 38.00 & 38.64 & 38.59 & 39.68 & 38.94 & 37.94 \\
\hline $\mathrm{TiO2}$ & 0.03 & 0.00 & 0.00 & 0.00 & 0.00 & 0.00 & 0.00 \\
\hline $\mathrm{A} 12 \mathrm{O} 3$ & 0.11 & 0.25 & 0.05 & 0.06 & 0.04 & 0.01 & 0.03 \\
\hline $\mathrm{Cr} 2 \mathrm{O} 3$ & 0.03 & 0.02 & 0.06 & 0.04 & 0.05 & 0.03 & 0.04 \\
\hline $\mathrm{FeO}$ & 16.68 & 16.74 & 17.93 & 17.78 & 18.10 & 18.02 & 18.16 \\
\hline $\mathrm{MnO}$ & 0.21 & 0.26 & 0.24 & 0.25 & 0.25 & 0.33 & 0.31 \\
\hline $\mathrm{MgO}$ & 43.37 & 43.80 & 43.19 & 42.67 & 40.76 & 42.69 & 44.01 \\
\hline $\mathrm{CaO}$ & 0.49 & 0.40 & 0.45 & 0.38 & 0.40 & 0.41 & 0.45 \\
\hline $\mathrm{Na} 2 \mathrm{O}$ & 0.00 & 0.00 & 0.00 & 0.00 & 0.00 & 0.00 & 0.00 \\
\hline $\mathrm{K} 2 \mathrm{O}$ & 0.00 & 0.00 & 0.00 & 0.00 & 0.00 & 0.00 & 0.00 \\
\hline P205 & 0.00 & 0.00 & 0.00 & 0.00 & 0.00 & 0.00 & 0.00 \\
\hline $\mathrm{NiO}$ & 0.17 & 0.13 & 0.13 & 0.17 & 0.18 & 0.26 & 0.18 \\
\hline Total & 99.77 & 99.60 & 100.68 & 99.94 & 99.46 & 100.69 & 101.11 \\
\hline Mg\# & 0.85 & 0.85 & 0.84 & 0.84 & 0.83 & 0.84 & 0.84 \\
\hline
\end{tabular}

\begin{tabular}{|c|c|c|c|c|c|c|c|c|c|c|c|c|c|}
\hline TAA B 26 & OLIVINE 43 & OLIVINE 48 & OLIVINE 49 & OLIVINE 50 & OLIVINE 51 & OLIVINE 52 & OLIVINE 53 & OLIVINE 58 & OLIVNNE 59 & OLIVINE 61 & OLIVINE 62 & OLIVINE 63 & OLIVINE 66 \\
\hline $\mathrm{SiO2}$ & 38.58 & 38.47 & 38.57 & 38.67 & 38.22 & 38.61 & 38.56 & 38.79 & 38.53 & 38.64 & 39.35 & 38.04 & 38.04 \\
\hline $\mathrm{TiO} 2$ & 0.02 & 0.02 & 0.02 & 0.00 & 0.03 & 0.00 & 0.02 & 0.01 & 0.02 & 0.01 & 0.00 & 0.01 & 0.02 \\
\hline Al2O3 & 0.06 & 0.04 & 0.04 & 0.06 & 0.05 & 0.07 & 0.02 & 0.08 & 0.06 & 0.04 & 0.06 & 0.05 & 0.06 \\
\hline $\mathrm{Cr} 2 \mathrm{O} 3$ & 0.04 & 0.05 & 0.02 & 0.04 & 0.03 & 0.02 & 0.04 & 0.00 & 0.00 & 0.00 & 0.00 & 0.05 & 0.01 \\
\hline $\mathrm{FeO}$ & 19.47 & 19,85 & 19.71 & 19.81 & 18.69 & 18.78 & 19.69 & 19.69 & 19.75 & 39.99 & 19.96 & 19.06 & 19.33 \\
\hline $\mathrm{MnO}$ & 0.26 & 0.22 & 0.30 & 0.29 & 0.24 & 0.25 & 0.26 & 0.32 & 0.26 & 0.27 & 0.27 & 0.23 & 0.27 \\
\hline $\mathrm{MgO}$ & 41.62 & 40.76 & 41.89 & 41.88 & 41.76 & 42.12 & 41.87 & 41.52 & 41.78 & 41.69 & 41.27 & 42.20 & 41.96 \\
\hline $\mathrm{CaO}$ & 0.33 & 0.26 & 0.31 & 0.31 & 0.31 & 0.29 & 0.28 & 0.31 & 0.28 & 0.27 & 0.28 & 0.26 & 0.26 \\
\hline $\mathrm{Na} 2 \mathrm{O}$ & 0.00 & 0.00 & 0.00 & 0.00 & 0.00 & 0.00 & 0.00 & 0.00 & 0.00 & 0.00 & 0.00 & 0.00 & 0.00 \\
\hline $\mathrm{K} 2 \mathrm{O}$ & 0.00 & 0.00 & 0.00 & 0.00 & 0.00 & 0.00 & 0.00 & 0.00 & 0.00 & 0.00 & 0.00 & 0.00 & 0.00 \\
\hline P2O5 & 0.00 & 0.00 & 0.00 & 0.00 & 0.00 & 0.00 & 0.00 & 0.00 & 0.00 & 0.00 & 0.00 & 0.00 & 0.00 \\
\hline NiO & 0.20 & 0.20 & 0.16 & 0.19 & 0.21 & 0.20 & 0.19 & 0.19 & 0.21 & 0.23 & 0.21 & 0.23 & 0.22 \\
\hline Total & 100.56 & 99.87 & 101.00 & 101.25 & 99.55 & 100.35 & 100.93 & 100.91 & 100.88 & 101.13 & t01.42 & 100.13 & 100.17 \\
\hline Mg\# & 0.83 & 0.82 & 0.82 & 0.82 & 0.83 & 0.83 & 0.82 & 0.82 & 0.82 & 0.82 & 0.82 & 0.83 & 0.83 \\
\hline
\end{tabular}


APPENDIX TABLE 2: Major element compositions of host Olivines

\begin{tabular}{|c|c|c|c|c|c|c|c|c|c|c|c|c|}
\hline MAG B 47 & OLIVINE 45 NI45A & OLIVINE $46-47$ & OLIVINE 48 & OLIVINE 49 & OLIVINE 50 & OLIVINE 51 & OLIVINE1 I51 & A OLIVINE $52-53$ & OLIVINE 54 & OLIVINE 55 & OLIVINE 56 & OLIVINE 57 \\
\hline $\mathrm{SiO} 2$ & 34.36 & 38.88 & 37.84 & 39.38 & 39.97 & 39.16 & 35.73 & 39.83 & 40.13 & 39.18 & 39.11 & 39.44 \\
\hline $\mathrm{TiO} 2$ & 0.10 & 0.01 & 0.02 & 0.00 & 0.00 & 0.00 & 0.08 & 0.01 & 0.00 & 0.00 & 0.00 & 0.01 \\
\hline $\mathrm{Al} 2 \mathrm{O} 3$ & 0.03 & 0.02 & 0.04 & 0.03 & 0.00 & 0.04 & 0.16 & 0.02 & 0.00 & 0.00 & 0.01 & 0.00 \\
\hline $\mathrm{Cr} 2 \mathrm{O} 3$ & 0.03 & 0.03 & 0.01 & 0.04 & 0.05 & 0.02 & 0.16 & 0.04 & 0.04 & 0.07 & 0.04 & 0.03 \\
\hline $\mathrm{FeO}$ & 39.06 & 17.26 & 18.91 & 13.15 & 13.33 & 17.86 & 34.30 & 14.69 & 14.23 & 12.94 & 13.08 & 14.37 \\
\hline $\mathrm{MnO}$ & 0.71 & 0.29 & 0.29 & 0.22 & 0.22 & 0.27 & 0.65 & 0.20 & 0.21 & 0.17 & 0.19 & 0.21 \\
\hline $\mathrm{MgO}$ & 23.05 & 43.53 & 41.68 & 46.95 & 47.07 & 43.43 & 27.55 & 44.94 & 46.13 & 47.52 & 43.88 & 44.88 \\
\hline $\mathrm{CaO}$ & 0.81 & 0.41 & 0.42 & 0.39 & 0.34 & 0.57 & 0.71 & 0.44 & 0.36 & 0.41 & 0.40 & 0.39 \\
\hline $\mathrm{Na} 2 \mathrm{O}$ & 0.00 & 0.00 & 0.00 & 0.00 & 0.00 & 0.00 & 0.00 & $\cdot 0.00$ & 0.00 & 0.00 & 0.00 & 0.00 \\
\hline $\mathrm{K} 2 \mathrm{O}$ & 0.00 & 0.00 & 0.00 & 0.00 & 0.00 & 0.00 & 0.00 & 0.00 & 0.00 & 0.00 & 0.00 & 0.00 \\
\hline $\mathrm{P} 2 \mathrm{OS}$ & 0.00 & 0.00 & 0.00 & 0.00 & 0.00 & 0.00 & 0.00 & 0.00 & 0.00 & 0.00 & 0.00 & 0.00 \\
\hline $\mathrm{NiO}$ & 0.05 & 0.20 & 0.17 & 0.17 & 0.25 & 0.17 & 0.12 & 0.23 & 0.23 & 0.20 & 0.24 & 0.24 \\
\hline Total & 98.20 & 100.62 & 99.37 & 100.33 & 101.22 & 101.52 & 99.45 & 100.40 & 101.32 & 100.49 & 96.96 & 99.59 \\
\hline Mg\# & 0.57 & 0.85 & 0.83 & 0.89 & 0.89 & 0.84 & 0.64 & 0.87 & 0.88 & 0.89 & 0.88 & 0.87 \\
\hline
\end{tabular}

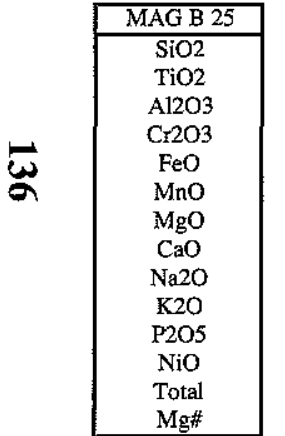

\begin{tabular}{|c|cc|}
\hline TAA B 26 & OLIVINE 67 & OLIVINE 68 \\
\hline $\mathrm{SiO2}$ & 38.25 & 38.79 \\
$\mathrm{TiO2}$ & 0.00 & 0.00 \\
$\mathrm{Al20}$ & 0.06 & 0.04 \\
$\mathrm{Cr} 203$ & 0.00 & 0.01 \\
$\mathrm{FeO}$ & 19.61 & 19.56 \\
$\mathrm{MrO}$ & 0.25 & 0.26 \\
$\mathrm{MgO}$ & 41.84 & 41.55 \\
$\mathrm{CaO}$ & 0.32 & 0.29 \\
$\mathrm{Na2O}$ & 0.00 & 0.00 \\
$\mathrm{~K} 20$ & 0.00 & 0.00 \\
$\mathrm{P} 2 \mathrm{O}$ & 0.00 & 0.00 \\
$\mathrm{NiO}$ & 0.20 & 0.20 \\
Total & 100.52 & 100.70 \\
$\mathrm{Mg} \#$ & 0.83 & 0.82 \\
\hline
\end{tabular}


APPENDIX TABLE 2: Major element compositions of host Olivines

\begin{tabular}{|c|c|c|c|c|c|c|c|c|c|c|c|c|c|}
\hline MAG B 47 & OLIVINE 58 & OLIVINE 59 & OLIVINE 60 & OLIVINE 61 & OLIVINE $61 \mathrm{~A}$ & OLIVINE NI 62 & OLIVINE 62 & OLIVINE NI 63 & OLIVINE 63 & OLNINE 64 & OLIVINE NI & 64 OLIVINE N & 166 OLIVINE $65-66$ \\
\hline $\mathrm{SiO2}$ & 39.39 & 38.32 & 39.13 & 38.36 & 38.66 & 38.10 & 39.06 & 39.12 & 39.40 & 39.62 & 40.36 & 45.88 & 38.83 \\
\hline $\mathrm{TiO} 2$ & 0.01 & 0.01 & 0.00 & 0.01 & 0.01 & 0.02 & 0.01 & 0.00 & 0.00 & 0.02 & 0.00 & 1.17 & 0.03 \\
\hline Al2O3 & 0.04 & 0.18 & 0.02 & 0.05 & 0.06 & 0.02 & 0.03 & 0.02 & 0.02 & 0.03 & 0.04 & 13.48 & 0.01 \\
\hline $\mathrm{Cr} 2 \mathrm{O} 3$ & 0.06 & 0.01 & 0.07 & 0.02 & 0.02 & 0.02 & 0.05 & 0.03 & 0.03 & 0.03 & 0.00 & 0.02 & 0.02 \\
\hline $\mathrm{FeO}$ & 13.10 & 17.62 & 13.17 & 18.11 & 18.14 & 15.31 & 14.67 & 15.21 & 14.97 & 13.12 & 15.22 & 8.22 & 17.69 \\
\hline $\mathrm{MnO}$ & 0.21 & 0.28 & 0.19 & 0.29 & 0.30 & 0.22 & 0.24 & 0.26 & 0.24 & 0.21 & 0.22 & 0.13 & 0.29 \\
\hline $\mathrm{MgO}$ & 45.47 & 41.98 & 45.46 & 42.15 & 42.18 & 46.19 & 45.23 & 45.26 & 45.34 & 45.92 & 44.81 & 7.34 & 42.55 \\
\hline $\mathrm{CaO}$ & 0.41 & 0.40 & 0.40 & 0.39 & 0.42 & 0.55 & 0.43 & 0.42 & 0.39 & 0.39 & 0.45 & 6.54 & 0.41 \\
\hline $\mathrm{Na} 2 \mathrm{O}$ & 0.00 & 0.00 & 0.00 & 0.00 & 0.00 & 0.00 & 0.00 & 0.00 & 0.00 & 0.00 & 0.00 & 0.00 & 0.00 \\
\hline $\mathrm{K} 2 \mathrm{O}$ & 0.00 & 0.00 & 0.00 & 0.00 & 0.00 & 0.00 & 0.00 & 0.00 & 0.00 & 0.00 & 0.00 & 0.00 & 0.00 \\
\hline $\mathrm{P} 2 \mathrm{O} 5$ & 0.00 & 0.00 & 0.00 & 0.00 & 0.00 & 0.00 & 0.00 & 0.00 & 0.00 & 0.00 & 0.00 & 0.00 & 0.00 \\
\hline NiO & 0.25 & 0.19 & 0.24 & 0.19 & 0.15 & 0.18 & 0.21 & 0.21 & 0.21 & 0.22 & 0.20 & 0.00 & 0.21 \\
\hline Total & 98.91 & 98.99 & 98.67 & 99.57 & 99.93 & 100.59 & 99.92 & 100.53 & 100.60 & 99.57 & 101.30 & 82.79 & 100.05 \\
\hline $\mathrm{Mg} \#$ & 0.88 & 0.84 & 0.88 & 0.84 & 0.84 & 0.87 & 0.87 & 0.87 & 0.87 & 0.89 & 0.87 & 0.66 & 0.84 \\
\hline
\end{tabular}

\begin{tabular}{|c|c|c|c|c|c|c|c|c|c|}
\hline MAG B 47 & OLIVINE NI 65 & OLIVINE 67 & OLIVINE N167 & OLIVINE 68 & OLIVINE 69 & OLIVINE 70 & OLIVINE 71 & OLIVINE 72 & OLIVINE I73 \\
\hline $\mathrm{SiO} 2$ & 38.90 & 39.10 & 38.21 & 39.45 & 39.11 & 39,04 & 39.31 & 38.91 & 38.43 \\
\hline $\mathrm{T} \mathrm{TO} 2$ & 0.05 & 0.00 & 0.03 & 0.00 & 0.00 & 0.01 & 0.01 & 0.00 & 0.02 \\
\hline $\mathrm{Al} 2 \mathrm{O} 3$ & 0.05 & 0.02 & 0.00 & 0.02 & 0.04 & 0.02 & 0.01 & 0.02 & 0.03 \\
\hline $\mathrm{Cr} 2 \mathrm{O} 3$ & 0.03 & 0.03 & 0.04 & 0.05 & 0.03 & 0.03 & 0.06 & 0.05 & 0.03 \\
\hline $\mathrm{FeO}$ & 17.83 & 15.91 & 17.43 & 13.32 & 13.31 & 15.00 & 13.00 & 15.10 & 17.79 \\
\hline $\mathrm{MnO}$ & 0.28 & 0.22 & 0.26 & 0.21 & 0.17 & 0.23 & 0.21 & 0.21 & 0.28 \\
\hline $\mathrm{MgO}$ & 42.02 & 43.85 & 43.39 & 45.49 & 44.59 & 44.06 & 45.78 & 44,26 & 41.47 \\
\hline $\mathrm{CaO}$ & 0.41 & 0.41 & 0.50 & 0.40 & 0.42 & 0.40 & 0.36 & 0.39 & 0.39 \\
\hline $\mathrm{Na} 2 \mathrm{O}$ & 0.00 & 0.00 & 0.00 & 0.00 & 0.00 & 0.00 & 0.00 & 0.00 & 0.00 \\
\hline $\mathrm{K} 2 \mathrm{O}$ & 0.00 & 0.00 & 0.00 & 0.00 & 0.00 & 0.00 & 0.00 & 0.00 & 0.00 \\
\hline $\mathrm{P} 205$ & 0.00 & 0.00 & 0.00 & 0.00 & 0.00 & 0.00 & 0.00 & 0.00 & 0.00 \\
\hline $\mathrm{NiO}$ & 0.20 & 0.19 & 0.14 & 0.24 & 0.26 & 0.21 & 0.24 & 0.22 & 0.20 \\
\hline Total & 99.78 & 99.73 & 99.99 & 99.18 & 97.92 & 99.02 & 98.98 & 99.16 & 98.63 \\
\hline $\mathrm{Mg} \#$ & 0.84 & 0.86 & 0.85 & 0.88 & 0.88 & 0.87 & 0.89 & 0.87 & 0.84 \\
\hline
\end{tabular}


APPENDIX TABLE 3: Major element compositions of host and daughter Clinopyroxenes compositions

\begin{tabular}{|c|c|c|c|c|c|c|c|c|c|c|}
\hline MAG B 47 & PYROXEN1 & PYROXEN 6 & PYROXEN 7 & PYROXEN 8 & PYROXEN 8 & PYROXEN 9 & PYROXEN 10 & PYROXEN 11 & PYROXEN 14 & PYROXEN IS \\
\hline $\mathrm{SiO} 2$ & 42.81 & 44.57 & 44.03 & 42.03 & 42.15 & 42.51 & 44.46 & $44.7 \mathrm{1}$ & 44.22 & 44.87 \\
\hline $\mathrm{TiO} 2$ & 5.87 & 4.54 & 4.64 & 5.24 & 5.56 & 4.59 & 4.08 & 3.72 & 4.47 & 2.84 \\
\hline $\mathrm{Al} 2 \mathrm{O} 3$ & 9.80 & 12.17 & 10.65 & 10.65 & 12.28 & 10.40 & 10.04 & 9.95 & 9.54 & 8.76 \\
\hline $\mathrm{Cr} 2 \mathrm{O} 3$ & 0.16 & 0.07 & 0.02 & 0.08 & 0.07 & 0.07 & 0.08 & 0.07 & 0.12 & 0.66 \\
\hline $\mathrm{FeO}$ & 6.29 & 7.07 & 8.29 & 8.96 & 7.95 & 8.41 & 7.99 & 8.22 & 6.09 & 7.67 \\
\hline $\mathrm{MnO}$ & 0.11 & 0.13 & 0.14 & 0.19 & 0.14 & 0.18 & 0.15 & 0.15 & 0.08 & 0.11 \\
\hline $\mathrm{MgO}$ & 10.50 & 9.54 & 9.46 & 10.48 & 9.02 & 9.09 & 9.83 & 10.41 & 11.44 & 10.93 \\
\hline $\mathrm{CaO}$ & 22.90 & 21.89 & 23.02 & 20.61 & 22.72 & 23.34 & 22.97 & 22.39 & 23.08 & 22.91 \\
\hline $\mathrm{Na} 2 \mathrm{O}$ & 0.65 & 0.80 & 0.69 & 0.54 & 0.68 & 0.89 & 0.63 & 0.53 & 0.72 & 0.59 \\
\hline $\mathrm{K} 2 \mathrm{O}$ & 0.00 & 0.00 & 0.00 & 0.00 & 0.00 & 0.00 & 0.00 & 0.00 & 0.00 & 0.00 \\
\hline P2OS & 0.00 & 0.00 & 0.00 & 0.00 & 0.00 & 0.00 & 0.00 & 0.00 & 0.00 & 0.00 \\
\hline $\mathrm{NiO}$ & 0.00 & 0.00 & 0.00 & 0.00 & 0.00 & 0.00 & 0.00 & 0.00 & 0.02 & 0.04 \\
\hline Total & 99.07 & 100.77 & 100.93 & 98.77 & 100.57 & 99.48 & 100.22 & 100.16 & 99.78 & 99.39 \\
\hline Mg\# & 0.79 & 0.75 & 0.72 & 0.71 & 0.71 & 0.71 & 0.73 & 0.73 & 0.81 & 0.76 \\
\hline
\end{tabular}

\begin{tabular}{|c|c|c|c|c|c|c|c|c|c|c|}
\hline MAG B 25 & PYROXEN Hi & PYROXEN H 4 & PYROXEN H 5 & PYROXEN H8-9 & PYROXEN H10-11 & PYROXEN H 18 & PYROXEN H19-23 & PYROXEN H24 & PYROXEN H 25 & PYROXEN H26 \\
\hline $\mathrm{SiO} 2$ & 50.56 & 49.62 & 50.12 & 50.84 & 50.06 & 51.29 & 51.29 & 50.90 & 50.92 & 50.53 \\
\hline $\mathrm{TiO} 2$ & 1.01 & 1.36 & 1.12 & 0.93 & 1.00 & 0.84 & 0.72 & 0.91 & 1.12 & 1.07 \\
\hline $\mathrm{Al} 2 \mathrm{O} 3$ & 3.35 & 4.05 & 4.09 & 3.26 & 4.01 & 3.07 & 2.63 & 3.16 & 3.49 & 3.71 \\
\hline $\mathrm{Cr} 2 \mathrm{O} 3$ & 0.66 & 0.64 & 0.97 & 0.78 & 0.91 & 0.64 & 0.90 & 0.60 & 0.48 & 0.81 \\
\hline $\mathrm{FeO}$ & 5.16 & 5.37 & 4.95 & 4.91 & 4.99 & 4.89 & 4.31 & 4.83 & 5.29 & 4.74 \\
\hline $\mathrm{MnO}$ & 0.12 & 0.09 & 0.00 & 0.00 & 0.00 & 0.00 & 0.00 & 0.00 & 0.17 & 0.00 \\
\hline $\mathrm{MgO}$ & 15.65 & 15.15 & 15.03 & 15.97 & 15.08 & 15.37 & 16.36 & 15.59 & 15.43 & 15.17 \\
\hline $\mathrm{CaO}$ & 22.57 & 22.71 & 22.40 & 21.86 & 22.24 & 22.36 & 22.15 & 22.13 & 22.34 & 22.29 \\
\hline $\mathrm{Na} 2 \mathrm{O}$ & 0.33 & 0.45 & 0.47 & 0.42 & 0.47 & 0.38 & 0.41 & 0.38 & 0.38 & 0.36 \\
\hline $\mathrm{k} 2 \mathrm{O}$ & 0.00 & 0.00 & 0.00 & 0.00 & 0.00 & 0.00 & 0.00 & 0.00 & 0.00 & 0.00 \\
\hline $\mathrm{P} 2 \mathrm{O} 5$ & 0.00 & 0.00 & 0.00 & 0.00 & 0.00 & 0.00 & 0.00 & 0.00 & 0.00 & 0.00 \\
\hline $\mathrm{NiO}$ & 0.01 & 0.06 & 0.00 & 0.00 & 0.00 & 0.00 & 0.00 & 0.03 & 0.19 & 0.01 \\
\hline Total & 99.43 & 99.50 & 99.15 & 98.96 & 98.75 & 98.84 & 98.78 & 98.52 & 99.80 & 98.69 \\
\hline $\mathrm{Mg} \#$ & 0.87 & 0.86 & 0.87 & 0.88 & 0.87 & 0.87 & 0.89 & 0.88 & 0.87 & 0.88 \\
\hline
\end{tabular}

\begin{tabular}{|c|c|c|c|c|c|c|c|c|c|c|}
\hline TAA B 26 & PYROXEN 1a & PYROXEN $1 \mathrm{~b}$ & PYROXEN 2 & PYROXEN 3 & PYROXEN core 4 & YROXEN margin & PYROXEN 5 & PYROXEN 6a & PYROXEN 6b & PYROXEN 8 \\
\hline $\mathrm{SiO} 2$ & 40.66 & 39.85 & 41.59 & 39.17 & 42.38 & 44.18 & 39.40 & 40.75 & 37.22 & 47.62 \\
\hline $\mathrm{TiO}_{2}$ & 5.91 & 5.98 & 6.90 & 6.05 & 3.73 & 3.32 & 7.54 & 2.36 & 7.03 & 2.44 \\
\hline $\mathrm{Al} 2 \mathrm{O} 3$ & 13.34 & 13.00 & 12.24 & 13.75 & 14.57 & 18.02 & 13.47 & 13.83 & 17.28 & 12.47 \\
\hline $\mathrm{Cr} 2 \mathrm{O} 3$ & 0.02 & 0.01 & 0.05 & 0.00 & 0.00 & 0.03 & 0.03 & 0.00 & 0.00 & 0.00 \\
\hline $\mathrm{FeO}$ & 8.00 & 7.97 & 6.66 & 9.55 & 7.52 & 6.50 & 8.81 & 7.21 & 8.84 & 9.66 \\
\hline $\mathrm{MnO}$ & 0.02 & 0.13 & 0.08 & 0.05 & 0.05 & 0.06 & 0.12 & 0.07 & 0.09 & 0.16 \\
\hline MgO & 8.93 & 8.99 & 10.79 & 7.62 & 8.68 & 2.95 & 9.16 & 10.18 & 6.74 & 6.19 \\
\hline $\mathrm{CaO}$ & 21.03 & 22.18 & 22.42 & 22.76 & 23.39 & 16.03 & 21.78 & 23.54 & 21.95 & 19.78 \\
\hline $\mathrm{Na} 2 \mathrm{O}$ & 0.50 & 0.44 & 0.61 & 0.53 & 0.49 & 2.77 & 0.65 & 0.42 & 1.61 & 1.12 \\
\hline $\mathrm{K} 2 \mathrm{O}$ & 0.00 & 0.00 & 0.00 & 0.00 & 0.00 & 0.00 & 0.00 & 0.00 & 0.00 & 0.00 \\
\hline $\mathrm{P} 205$ & 0.00 & 0.00 & 0.00 & 0.00 & 0.00 & 0.00 & 0.00 & 0.00 & 0.00 & 0.00 \\
\hline $\mathrm{NiO}$ & 0.00 & 0.00 & 0.00 & 0.00 & 0.00 & 0.00 & 0.00 & 0.00 & 0.00 & 0.00 \\
\hline Total & 98.42 & 98.54 & 101.33 & 99.48 & 100.81 & 93.86 & 100.95 & 98.36 & 100.74 & 99.44 \\
\hline Mg\# & 0.71 & 0.71 & 0.78 & 0.64 & 0.72 & 0.50 & 0.70 & 0.76 & 0.63 & 0.59 \\
\hline
\end{tabular}


APPENDIX TABLE 3: Major element compositions of host and daughter Clinopyroxenes compositions

\begin{tabular}{|c|c|c|c|c|c|c|c|c|c|c|}
\hline MAG B 47 & PYROXEN 16 & PYROXEN 17 & PYROXEN19 & PYROXEN 20 & PYROXEN 21 & PYROXEN 21 & PYROXEN 22 & PYROXEN 23 & PYROXEN 24 & PYROXEN 27 \\
\hline $\mathrm{SiO} 2$ & 43.95 & 45.07 & 44,80 & 40.52 & 52.19 & 47.83 & 42.98 & 41.21 & $47 . \overline{18}$ & 45.42 \\
\hline $\mathrm{TiO} 2$ & 4.87 & 4.01 & 6.07 & 7.47 & 0.79 & 2.72 & 5.26 & 5.84 & 2.58 & 3.05 \\
\hline $\mathrm{Al} 2 \mathrm{O} 3$ & 10.60 & 8.24 & 10.22 & 12.48 & 3.03 & 6.49 & 12.98 & 14.70 & 11.61 & 9.07 \\
\hline $\mathrm{Cr} 2 \mathrm{O} 3$ & 0.10 & 0.05 & 0.33 & 0.12 & 1.20 & 0.33 & 0.06 & 0.06 & 0.01 & 0.28 \\
\hline $\mathrm{FeO}$ & 7.69 & 8.49 & 6.32 & 6.63 & 4.00 & 7.34 & 6.44 & 7.63 & 9.23 & 7.00 \\
\hline MnO & 0.09 & 0.13 & 0.08 & 0.07 & 0.04 & 0.11 & 0.08 & 0.11 & 0.15 & 0.11 \\
\hline $\mathrm{MgO}$ & 8.92 & 9.97 & 10.78 & 10.54 & 15.83 & 12.65 & $\$ 1.10$ & 8.05 & 8.02 & 11.99 \\
\hline $\mathrm{CaO}$ & 23.37 & 23.53 & 22.69 & 19.63 & 23.49 & 23.01 & 20.35 & 22.81 & 21.92 & 22.39 \\
\hline $\mathrm{Na} 2 \mathrm{O}$ & 0.62 & 0.74 & 0.69 & 0.46 & 0.32 & 0.44 & 1.09 & 0.61 & 0.81 & 0.72 \\
\hline $\mathrm{K} 2 \mathrm{O}$ & 0.00 & 0.00 & 0.00 & 0.00 & 0.00 & 0.00 & 0.00 & 0.00 & 0.00 & 0.00 \\
\hline P205 & 0.00 & 0.00 & 0.00 & 0.00 & 0.00 & 0.00 & 0.00 & 0.00 & 0.00 & 0.00 \\
\hline $\mathrm{NiO}$ & 0.00 & 0.00 & 0.02 & 0.00 & 0.06 & 0.02 & 0.01 & 0.02 & 0.02 & 0.02 \\
\hline Total & 100.20 & 100.23 & 102.00 & 97.91 & 100.95 & 100.94 & 100.35 & 101.03 & 101.54 & 100.05 \\
\hline Mg\# & 0.72 & 0.72 & 0.79 & 0.78 & 0.90 & 0.79 & 0.79 & 0.70 & 0.66 & 0.79 \\
\hline
\end{tabular}

\begin{tabular}{|c|c|c|c|c|c|c|c|c|c|c|}
\hline MAG B 25 & PYROXEN H27-28 & 8 PYROXEN H 29 & PYROXEN H30-32 & PYROXEN H35 & PYROXEN H36 & PYROXEN H38-39 & PYROXEN H 41-42 & 2 PYROXEN H 44 & PYROXEN H 45 & PYROXEN H NI50 \\
\hline $\mathrm{SiO2}$ & 50.52 & 50.65 & 50.99 & 50.86 & 48.66 & 50.94 & 50.43 & 50.36 & 50.80 & 49.64 \\
\hline $\mathrm{TiO} 2$ & 1.06 & 1.01 & 0.88 & 0.93 & 0.77 & 0.94 & 1.12 & 1.32 & 0.94 & 1.29 \\
\hline $\mathrm{Al} 2 \mathrm{O} 3$ & 3.65 & 3.65 & 3.32 & 3.41 & 2.77 & 3.44 & 3.79 & 4.09 & 3.17 & 4.08 \\
\hline $\mathrm{Cr} 2 \mathrm{O} 3$ & 0.68 & 0.65 & 0.64 & 0.60 & 0.63 & 0.77 & 0.51 & 0.26 & 0.37 & 0.63 \\
\hline $\mathrm{FeO}$ & 5.12 & 5.17 & 4.86 & 4.69 & 4.27 & 4.80 & 4.84 & 5.50 & 4.86 & 5.67 \\
\hline $\mathrm{MnO}$ & 0.37 & 0.22 & 0.23 & 0.08 & 0.00 & 0.00 & 0.00 & 0.00 & 0.00 & 0.05 \\
\hline $\mathrm{MgO}$ & 15.44 & 15.59 & 15.53 & 15.65 & 16.84 & 15.41 & 15.25 & 14.79 & 15.51 & 14.27 \\
\hline $\mathrm{CaO}$ & 22.52 & 22.08 & 21.80 & 22.20 & 22.30 & 22.01 & 22.19 & 22.36 & 22.37 & 22.83 \\
\hline $\mathrm{Na} 2 \mathrm{O}$ & 0.41 & 0.38 & 0.39 & 0.40 & 0.39 & 0.45 & 0.36 & 0.39 & 0.34 & 0.00 \\
\hline $\mathrm{K} 2 \mathrm{O}$ & 0.00 & 0.00 & 0.00 & 0.00 & 0.00 & 0.00 & 0.00 & 0.00 & 0.00 & 0.00 \\
\hline $\mathrm{P} 2 \mathrm{O} 5$ & 0.00 & 0.00 & 0.00 & 0.00 & 0.00 & 0.00 & 0.00 & 0.00 & 0.00 & 0.00 \\
\hline $\mathrm{NiO}$ & 0.25 & 0.19 & 0.29 & 0.00 & 0.04 & 0.00 & 0.00 & 0.00 & 0.00 & 0.00 \\
\hline Total & 100.01 & 99.56 & 98.92 & 98.81 & 96.67 & 98.75 & 98.47 & 99.06 & 98.35 & 98.47 \\
\hline $\mathrm{Mg \#}$ & 0.87 & 0.87 & 0.88 & 0.88 & 0.90 & 0.88 & 0.87 & 0.86 & 0.88 & 0.85 \\
\hline
\end{tabular}

\begin{tabular}{|c|c|c|c|c|c|c|c|c|c|c|}
\hline TAA B 26 & PYROXEN 9 & PYROXEN 10a & PYROXEN10b & PYROXEN 12 & PYROXEN 14 & PYROXEN 15 & PYROXEN 16a & PYROXEN $16 \mathrm{~b}$ & PYROXEN 16c & PYROXEN 17a \\
\hline $\mathrm{SiO} 2$ & 43.29 & 39.07 & 43.34 & 44.02 & 39.98 & 45.28 & 49.30 & 50.28 & 43.31 & 49.02 \\
\hline $\mathrm{TiO} 2$ & 4.77 & 7.83 & 5.34 & 3.96 & 6.97 & 3.93 & 1.69 & 1.55 & 5.11 & 1.97 \\
\hline Al2O3 & 10.96 & 13.40 & 11.51 & 12.63 & 15.11 & 9.52 & 4.98 & 4.81 & 11.85 & 5.30 \\
\hline $\mathrm{Cr} 2 \mathrm{O} 3$ & 0.15 & 0.04 & 0.00 & 0.00 & 0.00 & 0.06 & 0.90 & 0.86 & 0.12 & 0.62 \\
\hline $\mathrm{FeO}$ & 7.61 & 7.35 & 8.06 & 9.51 & 9.15 & 7.48 & 6.44 & 6.35 & 5.99 & 6.88 \\
\hline MnO & 0.10 & 0.12 & 0.15 & 0.13 & 0.12 & 0.15 & 0.12 & 0.13 & 0.15 & 0.13 \\
\hline $\mathrm{MgO}$ & 11.60 & 9.61 & 11.52 & 6.68 & 10.47 & 12.44 & 14.93 & 15.03 & 11.58 & 14.77 \\
\hline $\mathrm{CaO}$ & 21.79 & 22.29 & 20.61 & 21.93 & 17.33 & 21.74 & 21.90 & 21.89 & 21.93 & 21.86 \\
\hline $\mathrm{Na} 2 \mathrm{O}$ & 0.59 & 0.72 & 0.74 & 1.25 & 1.47 & 0.57 & 0.42 & 0.44 & 0.59 & 0.42 \\
\hline $\mathrm{K} 2 \mathrm{O}$ & 0.00 & 0.00 & 0.00 & 0.00 & 0.00 & 0.00 & 0.00 & 0.00 & 0.00 & 0.00 \\
\hline $\mathrm{P} 2 \mathrm{O} 5$ & 0.00 & 0.00 & 0.00 & 0.00 & 0.00 & 0.00 & 0.00 & 0.00 & 0.00 & 0.00 \\
\hline $\mathrm{NiO}$ & 0.00 & 0.00 & 0.00 & 0.00 & 0.00 & 0.00 & 0.00 & 0.00 & 0.00 & 0.00 \\
\hline Total & 100.85 & 100.42 & 101.27 & 100.11 & 100.62 & 101.18 & 100.67 & 101.32 & 100.63 & 100.97 \\
\hline Mg\# & 0.77 & 0.74 & 0.76 & 0.61 & 0.72 & 0.79 & 0.84 & 0.84 & 0.81 & 0.83 \\
\hline
\end{tabular}


APPENDIX TABLE 3: Major element compositions of host and daughter Clinopyroxenes compositions

\begin{tabular}{|c|c|c|c|c|c|c|c|c|c|c|c|}
\hline MAG B 47 & PYROXEN 29 & PYROXEN 30 & PYROXEN 31 & PYROXEN 32 & PYROXEN 33 & PYROXEN 33A & PYROXEN 33B & PYROXEN 33B & PYROXEN 36 & PYROXEN 37 & PYROXEN 38 \\
\hline $\mathrm{SiO} 2$ & 44.50 & 45.59 & 41.77 & 43.61 & 43.02 & 46.22 & 43.26 & 48.20 & 40.93 & 41.54 & 42.31 \\
\hline $\mathrm{TiO} 2$ & 4.81 & 4.15 & 8.05 & 4.85 & 4.34 & 4.24 & 4.45 & 3.03 & 6.18 & 5.66 & 5.09 \\
\hline $\mathrm{Al} 2 \mathrm{O} 3$ & 10.47 & 9.79 & 12.78 & 10.25 & 12.75 & 11,33 & 11.39 & 9.87 & 12.03 & 12.69 & 11.14 \\
\hline $\mathrm{Cr} 2 \mathrm{O} 3$ & 0.12 & 0.10 & 0.08 & 0.18 & 0.01 & 0.11 & 0.06 & 0.07 & 0.03 & 0.08 & 0.04 \\
\hline $\mathrm{FeO}$ & 5.79 & 6.36 & 7.35 & 6.94 & 7.49 & 7.33 & 7.68 & 6.76 & 7.05 & 8.01 & 7.95 \\
\hline $\mathrm{MnO}$ & 0.07 & 0.10 & 0.09 & 0.09 & 0.11 & 0.14 & 0.15 & 0.14 & 0.09 & 0.10 & 0.09 \\
\hline $\mathrm{MgO}$ & 10.79 & 11.19 & 7.71 & 11.12 & 9.11 & 10.22 & 9.93 & 12.66 & 9.89 & 11.65 & 8.64 \\
\hline $\mathrm{CaO}$ & 23.33 & 23.10 & 23.02 & 22.84 & 22.52 & 21.04 & 22.24 & 21.52 & 22.78 & 18.97 & 23.08 \\
\hline $\mathrm{Na} 2 \mathrm{O}$ & $0.6 \mathrm{I}$ & 0.57 & 0.70 & 0.66 & 0.77 & 0.81 & 0.69 & 0.74 & 0.44 & 1.08 & 0.56 \\
\hline $\mathrm{K} 2 \mathrm{O}$ & 0.00 & 0.00 & 0.00 & 0.00 & 0.00 & 0.00 & 0.00 & 0.00 & 0.00 & 0.00 & 0.00 \\
\hline $\mathrm{P} 2 \mathrm{O} 5$ & 0.00 & 0.00 & 0.00 & 0.00 & 0.00 & 0.00 & 0.00 & 0.00 & 0.00 & 0.00 & 0.00 \\
\hline $\mathrm{NiO}$ & 0.06 & 0.02 & 0.02 & 0.02 & 0.03 & 0.02 & 0.00 & 0.00 & 0.00 & 0.00 & 0.00 \\
\hline Total & 100.54 & 100.99 & 101.56 & 100.56 & 100.15 & 101.45 & 99.84 & 102.99 & 99.41 & 99.80 & 98.91 \\
\hline $\mathrm{Mg} \#$ & 0.80 & 0.79 & 0.70 & 0.78 & 0.73 & 0.76 & 0.74 & 0.80 & 0.76 & 0.76 & 0.71 \\
\hline
\end{tabular}

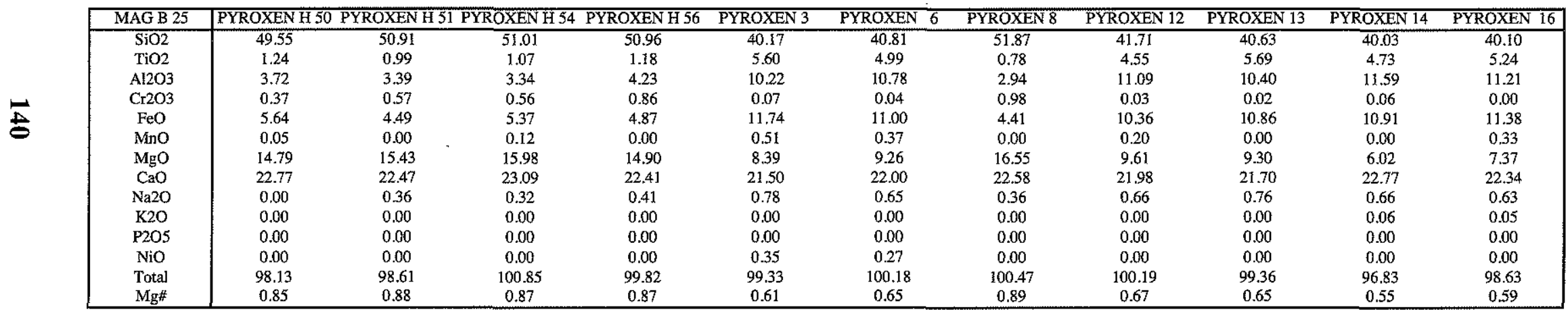

\begin{tabular}{|c|c|c|c|c|c|c|c|c|c|c|c|}
\hline TAA B 26 & PYROXEN 176 & PYROXEN 18 & PYROXEN 20 & PYROXEN 21 & PYROXEN 22 & PYROXEN 30 & PYROXEN 32 & PYROXEN 33 & PYROXEN 34 & PYROXEN 40 & PYROXEN 48a \\
\hline $\mathrm{SiO} 2$ & 43.71 & 43.87 & 48.85 & 42.26 & 41.86 & 45.54 & 47.22 & 44.36 & 44.59 & 39.36 & 45.72 \\
\hline $\mathrm{TiO} 2$ & 4.33 & 4.98 & 2.39 & 3.04 & 5.39 & 3.61 & 2.93 & 4.26 & 4.33 & 6.76 & 3.87 \\
\hline Al2O3 & 10.24 & 12.26 & 5.03 & 13.86 & 12.07 & 8.83 & 7.08 & 8.39 & 10.58 & 14.76 & 9.16 \\
\hline $\mathrm{Cr} 2 \mathrm{O} 3$ & 0.03 & 0.08 & 0.10 & 0.00 & 0.07 & 0.02 & 0.20 & 0.05 & 0.21 & 0.00 & 0.04 \\
\hline $\mathrm{FeO}$ & 7.76 & 7.44 & 7.50 & 8.18 & 7.03 & 7.00 & 7.44 & 8.96 & 6.17 & 8.14 & 7.75 \\
\hline $\mathrm{MnO}$ & 0.10 & 0.18 & 0.12 & 0.11 & 0.14 & 0.12 & 0.13 & 0.15 & 0.12 & 0.09 & 0.13 \\
\hline $\mathrm{MgO}$ & 11.99 & 11.28 & 14.82 & 8.58 & 11.06 & 12.59 & $13.6 \hat{3}$ & 11.79 & 12.29 & 8.12 & 12.40 \\
\hline $\mathrm{CaO}$ & 22.01 & 20.04 & 22.06 & 23.40 & 21.83 & 21.80 & 21.76 & 21.75 & 21.92 & 22.73 & 21.67 \\
\hline $\mathrm{Na} 2 \mathrm{O}$ & 0.51 & 0.95 & 0.35 & 0.45 & 0.62 & 0.45 & 0.46 & 0.52 & 0.58 & 0.61 & 0.53 \\
\hline $\mathrm{K} 2 \mathrm{O}$ & 0.00 & 0.00 & 0.00 & 0.00 & 0.00 & 0.00 & 0.00 & 0.00 & 0.00 & 0.00 & 0.00 \\
\hline $\mathrm{P} 2 \mathrm{O} 5$ & 0.00 & 0.00 & 0.00 & 0.00 & 0.00 & 0.00 & 0.00 & 0.00 & 0.00 & 0.00 & 0.00 \\
\hline $\mathrm{NiO}$ & 0.00 & 0.00 & 0.00 & 0.00 & 0.00 & 0.00 & 0.00 & 0.00 & 0.00 & 0.00 & 0.00 \\
\hline Total & 100.68 & 101.07 & 101.22 & 99.85 & 100.08 & 99.97 & 100.86 & 100.22 & 100.79 & 100.57 & 101.28 \\
\hline Mg\# & 0.77 & 0.77 & 0.81 & 0.70 & 0.78 & 0.80 & 0.80 & 0.74 & 0.81 & 0.69 & 0.78 \\
\hline
\end{tabular}


APPENDIX TABLE 3: Major element compositions of host and daughter Clinopyroxenes compositions

\begin{tabular}{|c|c|c|c|c|c|c|c|c|c|c|c|}
\hline MAG B 47 & PYROXEN 39 & PYROXEN 39B & PYROXEN 40 & PYROXEN 41 & PYROXEN 42 & PYROXEN 44 & PYROXEN 45 & PYROXEN 45A & PYROXEN 45A & PYROXEN 46 & PYROXEN 48 \\
\hline $\mathrm{SiO} 2$ & 43.35 & 43.44 & 42.12 & 46.42 & 41.05 & 42.22 & 43.89 & 49.69 & 47.70 & 40.01 & 41.37 \\
\hline $\mathrm{TiO} 2$ & 4.14 & 4.72 & 5.00 & 2.08 & 5.24 & 5.43 & 2.91 & 1.50 & 2.91 & 5.51 & 5.81 \\
\hline $\mathrm{Al} 2 \mathrm{O} 3$ & 9.70 & 30.28 & 10.46 & 6.71 & 13.70 & 13.38 & 10.24 & 1.52 & 4.35 & 13.06 & 13.35 \\
\hline $\mathrm{C}+2 \mathrm{O} 3$ & 0.04 & 0.06 & 0.04 & 0.02 & 0.04 & 0.00 & 0.00 & 0.00 & 0.00 & 0.01 & 0.01 \\
\hline $\mathrm{FeO}$ & 7.17 & 7.42 & 6.81 & 12.46 & 6.71 & 9.25 & 8.84 & 14.92 & 13.80 & 8.86 & 10.13 \\
\hline $\mathrm{MnO}$ & 0.09 & 0.11 & 0.10 & 0.20 & 0.11 & 0.16 & 0.15 & 0.32 & 0.25 & 0.11 & 0.13 \\
\hline $\mathrm{MgO}$ & 10.05 & 9.89 & 10.23 & 8.78 & 7.92 & 7.51 & 9.15 & 8.92 & 8.38 & 9.19 & 8.42 \\
\hline $\mathrm{CaO}$ & 23.18 & 23.62 & 23.09 & 22.39 & 22.43 & 21.34 & 21.96 & 21.18 & 21.45 & 21.62 & 19.90 \\
\hline $\mathrm{Na} 2 \mathrm{O}$ & 0.41 & 0.58 & 0.50 & 0.63 & 0.66 & 0.96 & 0.42 & 1.12 & 0.99 & 0.92 & 1.02 \\
\hline $\mathrm{K} 2 \mathrm{O}$ & 0.00 & 0.00 & 0.00 & 0.00 & 0.00 & 0.00 & 0.00 & 0.00 & 0.00 & 0.00 & 0.00 \\
\hline $\mathrm{P} 2 \mathrm{O} 5$ & 0.00 & 0.00 & 0.00 & 0.00 & 0.00 & 0.00 & 0.00 & 0.00 & 0.00 & 0.00 & 0.00 \\
\hline $\mathrm{NaO}$ & 0.00 & 0.00 & 0.00 & 0.00 & 0.00 & 0.00 & 0.00 & 0.00 & 0.00 & 0.00 & 0.00 \\
\hline Total & 98.13 & 100.10 & 98.34 & 99.67 & 97.85 & 100.25 & 97.56 & 99.15 & 99.83 & 99.29 & 300.15 \\
\hline $\mathrm{Mg} \#$ & 0.76 & 0.75 & 0.77 & 0.61 & 0.72 & 0.64 & 0.68 & 0.57 & 0.57 & 0.69 & 0.64 \\
\hline
\end{tabular}

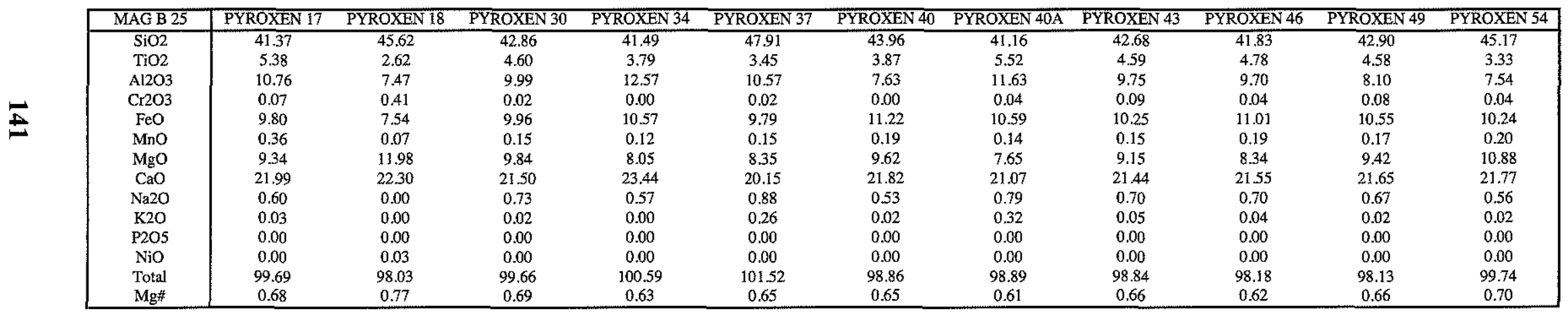

\begin{tabular}{|c|cccccccc|}
\hline TAA B 26 & PYROXEN 48b & PYROXEN 51a & PYROXEN 51b & PYROXEN 59a & PYROXEN 59b & PYROXEN 61 & PYROXEN 66 & PYROXEN 67 \\
\hline $\mathrm{SiO2}$ & 39.79 & 40.44 & 24.80 & 37.77 & 41.28 & 45.56 & 43.54 & 41.97 \\
$\mathrm{TiO2}$ & 7.32 & 6.37 & 11.87 & 8.99 & 4.76 & 3.70 & 4.25 & 6.01 \\
$\mathrm{Al2O3}$ & 16.42 & 12.53 & 18.78 & 17.31 & 14.88 & 9.25 & 9.51 & 10.74 \\
$\mathrm{Cr} 2 \mathrm{O} 3$ & 0.00 & 0.01 & 0.14 & 0.00 & 0.00 & 0.02 & 0.06 & 0.03 \\
$\mathrm{FeO}$ & 8.25 & 6.63 & 18.72 & 10.74 & 7.60 & 6.53 & 7.53 & 7.37 \\
$\mathrm{MnO}$ & 0.12 & 0.14 & 0.15 & 0.14 & 0.09 & 0.14 & 0.10 & 0.11 \\
$\mathrm{MgO}$ & 12.95 & 10.44 & 12.83 & 9.99 & 8.52 & 13.13 & 12.19 & 11.67 \\
$\mathrm{CaO}$ & 11.70 & 23.52 & 12.47 & 12.16 & 22.97 & 22.36 & 22.28 & 2.94 \\
$\mathrm{Na2O}$ & 2.63 & 0.53 & 0.88 & 2.30 & 0.67 & 0.45 & 0.46 & 0.54 \\
$\mathrm{~K} 2 \mathrm{O}$ & 0.00 & 0.00 & 0.00 & 0.00 & 0.00 & 0.00 & 0.00 & 0.00 \\
$\mathrm{P2O5}$ & 0.00 & 0.00 & 0.00 & 0.00 & 0.00 & 0.00 & 0.00 & 0.00 \\
$\mathrm{NiO}$ & 0.00 & 0.00 & 0.00 & 0.00 & 0.00 & 0.00 & 0.00 & 0.00 \\
$\mathrm{Total}$ & 99.16 & 100.60 & 100.63 & 99.38 & 100.77 & 101.14 & 99.91 & 100.37 \\
$\mathrm{Mg} \#$ & 0.78 & 0.78 & 0.60 & 0.67 & 0.71 & 0.82 & 0.78 & 0.78 \\
\hline
\end{tabular}


APPENDIX TABLE 3: Major element compositions of host and daughter Clinopyroxenes compositions

\begin{tabular}{|c|c|c|c|c|c|c|c|c|c|c|c|}
\hline MAG B 47 & PYROXEN 49 & PYROXEN 50 & PYROXEN 51 & PYROXEN 52 & PYROXEN 53 & PYROXEN 54 & PYROXEN 54 & PYROXEN 55 & PYROXEN 56 & PYROXEN 57 & PYROXEN 58 \\
\hline $\mathrm{SiO} 2$ & 41.41 & 44.39 & 44.37 & 43.25 & 42.92 & 45.37 & 40.65 & 42.29 & 44.38 & 40.20 & 44.83 \\
\hline TiO2 2 & 8.04 & 4.25 & 4.07 & 4.51 & 4.86 & 3.65 & 5.79 & 5.52 & 4.22 & 6.92 & 4.75 \\
\hline $\mathrm{Al} 2 \mathrm{O}^{3}$ & 11.80 & 10.61 & 9.58 & 11.64 & 10.17 & 9.48 & 12.80 & 12.03 & 9.98 & 12.83 & 10.29 \\
\hline $\mathrm{Cr} 2 \mathrm{O} 3$ & 0.01 & 0.04 & 0.00 & 0.04 & 0.06 & 0.06 & 0.05 & 0.10 & 0.09 & 0.06 & 0.10 \\
\hline $\mathrm{FeO}$ & 8.20 & 6.81 & 6.93 & 6.44 & 9.97 & 5.99 & 5.95 & 6.93 & 8.70 & 8.93 & 6.84 \\
\hline $\mathrm{MnO}$ & 0.10 & 0.10 & 0.12 & 0.06 & 0.15 & 0.13 & 0.08 & 0.11 & 0.13 & 0.34 & 0.54 \\
\hline $\mathrm{MgO}$ & 8.96 & 10.41 & 10.96 & 10.26 & 8.02 & 12.45 & 10.69 & 9.72 & 8.77 & 10.29 & 9.63 \\
\hline $\mathrm{CaO}$ & 22.63 & 23.00 & 22.68 & 23.36 & 22.85 & 22.55 & 22.51 & 22.97 & 23.16 & 17.01 & 22.67 \\
\hline $\mathrm{Na} 2 \mathrm{O}$ & 0.64 & 0.52 & 0.50 & 0.49 & 0.57 & 0.45 & 0.63 & 0.59 & 0.59 & 1.81 & 0.56 \\
\hline $\mathrm{K} 2 \mathrm{O}$ & 0.00 & 0.00 & 0.00 & 0.00 & 0.00 & 0.00 & 0.00 & 0.00 & 0.00 & 0.00 & 0.00 \\
\hline P2O5 & 0.00 & 0.00 & 0.00 & 0.00 & 0.00 & 0.00 & 0.00 & 0.00 & 0.00 & 0.00 & 0.00 \\
\hline $\mathrm{NiO}$ & 0.00 & 0.00 & 0.00 & 0.00 & 0.00 & 0.00 & 0.01 & 0.00 & 0.00 & 0.17 & 0.36 \\
\hline Total & 101.77 & 100.13 & 99.20 & 100.02 & 99.56 & 100.12 & 99.17 & 100.25 & 100.00 & 98.55 & 100.57 \\
\hline $\mathrm{Mg} \#$ & 0.71 & 0.77 & 0.78 & 0.78 & 0.64 & 0.82 & 0.80 & 0.76 & 0.69 & 0.72 & 0.76 \\
\hline
\end{tabular}

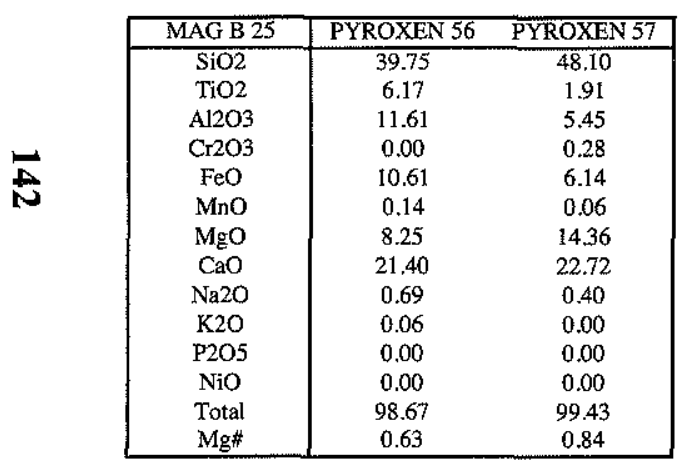


APPENDIX TABLE 3: Major element compositions of host and daughter Clinopyroxenes compositions

\begin{tabular}{|c|c|c|c|c|c|c|c|c|c|c|c|}
\hline MAG B 47 & PYROXEN 59 & PYROXEN 60 & PYROXEN 61 & PYROXEN 62 & PYROXEN 63 & PYROXEN 64 & PYROXEN 65 & PYROXEN 66 & PYROXEN 67 & PYROXEN 69 & PYROXEN 70 \\
\hline $\mathrm{SiO} 2$ & 41.72 & 43.65 & 42.78 & 43.43 & 44.78 & 42.96 & 39.86 & 41.62 & 42.52 & 43.47 & 45.34 \\
\hline $\mathrm{TiO} 2$ & 5.68 & 5.11 & 5.18 & 3.66 & 3.37 & 4.21 & 5.62 & 6.47 & 4.49 & 4.16 & 4.39 \\
\hline $\mathrm{Al} 2 \mathrm{O} 3$ & 13.03 & 10.06 & 12.05 & 10.32 & 10.32 & 11.01 & 13.07 & 13.26 & 10.97 & 9.68 & 12.25 \\
\hline $\mathrm{Cr} 2 \mathrm{O} 3$ & 0.06 & 0.09 & 0.02 & 0.06 & 0.11 & 0.03 & 0.09 & 0.06 & 0.11 & 0.06 & 0.14 \\
\hline $\mathrm{FeO}$ & 9.33 & 7.38 & 7.64 & 7.35 & 7.28 & 6.40 & 7.16 & 8.19 & 7.28 & 8.23 & 5.16 \\
\hline $\mathrm{MnO}$ & 0.59 & 0.61 & 0.12 & 0.33 & 0.34 & 0.53 & 0.18 & 0.14 & 0.09 & 0.15 & 0.08 \\
\hline $\mathrm{MgO}$ & 7.14 & 10.08 & 9.91 & 10.47 & 10.94 & 11.47 & 9.41 & 7.70 & 10.27 & 9.06 & 10.09 \\
\hline $\mathrm{CaO}$ & 22.74 & 23.16 & 22.36 & 23.05 & 22.51 & 22,83 & 22.55 & 22.09 & 22.37 & 22.20 & 19.19 \\
\hline $\mathrm{Na} 2 \mathrm{O}$ & 0.67 & 0.66 & 0.64 & 0.58 & 0.57 & 0.54 & 0.71 & 0.63 & 0.59 & 0.92 & 1.25 \\
\hline $\mathrm{K} 2 \mathrm{O}$ & 0.00 & 0.00 & 0.00 & 0.00 & 0.00 & 0.00 & 0.00 & 0.00 & 0.00 & 0.00 & 0.00 \\
\hline P2O5 & 0.00 & 0.00 & 0.00 & 0.00 & 0.00 & 0.00 & 0.00 & 0.00 & 0.00 & 0.00 & 0.00 \\
\hline $\mathrm{NiO}$ & 0.40 & 0.40 & 0.00 & 0.18 & 0.17 & 0.33 & 0.06 & 0.00 & 0.00 & 0.00 & 0.00 \\
\hline Total & 101.37 & 101.21 & 100.71 & 99.42 & 100.38 & 100.32 & 98.70 & 100.15 & 98.68 & 97.91 & 97.90 \\
\hline $\mathrm{Mg} \#$ & 0.63 & 0.75 & 0.74 & 0.76 & 0.77 & 0.80 & 0.74 & 0.68 & 0.76 & 0.71 & 0.81 \\
\hline
\end{tabular}

\begin{tabular}{|c|c|c|}
\hline MAG B 47 & PYROXEN 71 & PYROXEN 72 \\
\hline $\mathrm{SiO} 2$ & 49.32 & 42.00 \\
\hline $\mathrm{TiO} 2$ & 1.91 & 5.26 \\
\hline $\mathrm{Al} 2 \mathrm{O} 3$ & 5.10 & 11.74 \\
\hline $\mathrm{Cr} 2 \mathrm{O} 3$ & 0.31 & 0.07 \\
\hline $\mathrm{FeO}$ & 5.38 & 7.69 \\
\hline $\mathrm{MnO}$ & 0.05 & 0.14 \\
\hline $\mathrm{MgO}$ & 14.53 & 10.84 \\
\hline $\mathrm{CaO}$ & 22.56 & 19.34 \\
\hline $\mathrm{Na} 2 \mathrm{O}$ & 0.46 & 1.50 \\
\hline $\mathrm{K} 2 \mathrm{O}$ & 0.00 & 0.00 \\
\hline P2O5 & 0.00 & 0.00 \\
\hline $\mathrm{NiO}$ & 0.05 & 0.00 \\
\hline Total & 99.66 & 98.58 \\
\hline Mg\# & 0.86 & 0.76 \\
\hline
\end{tabular}


APPENDIX TABLE 4: Major element compositions of daughter mineral

\begin{tabular}{|c|c|c|c|c|c|c|c|c|c|c|c|c|}
\hline MAG B 47 & AMPH 13 & AMPH 18 & AMPH 23 & AMPH 27 & AMPH 34 & AMPH 44 & AMPH 54 & AMPH 61 & AMPH 65 & AMPH 66 & AMPH 68 & AMPH 70 \\
\hline $\mathrm{SiO} 2$ & 38.18 & 39.53 & 37.76 & 36.92 & 40.10 & 37.71 & 37.75 & 38.93 & 36.95 & 38.37 & 40.84 & 40.93 \\
\hline $\mathrm{TiO} 2$ & 9.80 & 8.16 & 8.72 & 8.00 & 5.04 & 8.28 & 6.24 & 8.37 & 8.57 & 8.72 & 7.71 & 5.74 \\
\hline $\mathrm{A} 12 \mathrm{O} 3$ & 14.71 & 14,48 & 15.76 & 12.14 & 14.13 & 14.57 & 16.40 & 14.02 & 14.38 & 15.39 & 13.50 & 10.47 \\
\hline $\mathrm{Cr} 2 \mathrm{O} 3$ & 0.10 & 0.03 & 0.02 & 0.13 & 0.02 & 0.00 & 0.00 & 0.05 & 0.04 & 0.01 & 0.06 & 0.07 \\
\hline $\mathrm{FeO}$ & 8.84 & 10.01 & 9.99 & 7.45 & 8.12 & 11.21 & 8.09 & 9.35 & 10.06 & 9.89 & 6.54 & 6.62 \\
\hline $\mathrm{MnO}$ & 0.14 & 0.11 & 0.12 & 0.05 & 0.11 & 0.17 & 0.09 & 0.12 & 0.16 & 0.14 & 0.07 & 0.10 \\
\hline $\mathrm{MgO}$ & 11.77 & 10.81 & 10.93 & 13.49 & 13.06 & 10.10 & 12.80 & 10.53 & 11.64 & 10.41 & 12.45 & 10.66 \\
\hline $\mathrm{CaO}$ & 11.96 & 12.82 & 12.31 & 11.38 & 11.85 & 11.79 & 12.04 & 14.03 & 12.18 & 12.38 & 12.89 & 22.64 \\
\hline $\mathrm{Na} 2 \mathrm{O}$ & 2.81 & 2.80 & 2.68 & 3.04 & 2.69 & 2.49 & 3.12 & 2.07 & 3.06 & 2.68 & 2.27 & 0.68 \\
\hline $\mathrm{K} 2 \mathrm{O}$ & 0.07 & 0.10 & 0.31 & 0.40 & 0.47 & 0.00 & 0.00 & 0.05 & 0.00 & 0.24 & 0.54 & 0.06 \\
\hline $\mathrm{P} 2 \mathrm{O} 5$ & 0.00 & 0.00 & 0.00 & 0.00 & 0.00 & 0.00 & 0.00 & 0.00 & 0.00 & 0.00 & 0.00 & 0.00 \\
\hline $\mathrm{NiO}$ & 0.00 & 0.01 & 0.02 & 0.00 & 0.00 & 0.00 & 0.00 & 0.00 & 0.00 & 0.01 & 0.00 & 0.00 \\
\hline Total & 98.38 & 98.85 & 98.62 & 92.99 & 95.59 & 96.32 & 96.52 & 97.52 & 97.04 & 98.24 & 96.86 & 97.96 \\
\hline $\mathrm{MAG}$ B 25 & AMPH 1 & AMPH 2 & AMPH 3 & AMPH 4 & AMPH 5 & AMPH 7 & AMPH 8 & AMPH 9 & AMPH 10 & AMPH $11 \mathrm{~A}$ & AMPH 12 & AMPH 15 \\
\hline $\mathrm{SiO} 2$ & 36.67 & 38.60 & 42.39 & 37.43 & 38.09 & 38.44 & 38.00 & 38.36 & 37.29 & 36.48 & 38.68 & 37.43 \\
\hline $\mathrm{TiO} 2$ & 2.58 & 5.45 & 1.66 & 5.08 & 5.06 & 5.44 & 5.09 & 4.50 & 3.44 & 3.76 & 5.20 & 6.05 \\
\hline $\mathrm{Al} 2 \mathrm{O} 3$ & 16.66 & 13.76 & 14.39 & 17.19 & 15.41 & 14.44 & 16.12 & 14.45 & 16.21 & 17.37 & 14.70 & 13.93 \\
\hline $\mathrm{C}_{2} 2 \mathrm{O} 3$ & 0.00 & 0.00 & 0.00 & 0.00 & 0.06 & 0.00 & 0.03 & 0.04 & 0.06 & 0.09 & 0.02 & 0.04 \\
\hline $\mathrm{FeO}$ & 18.31 & 12.63 & 13.09 & 14.75 & 12.93 & 10.84 & 12.84 & 12.66 & 15.12 & 13.37 & 11.52 & 12.58 \\
\hline $\mathrm{MnO}$ & 0.23 & 0.06 & 0.20 & 0.27 & 0.12 & 0.11 & 0.00 & 0.00 & 0.00 & 0.00 & 0.00 & 0.19 \\
\hline $\mathrm{MgO}$ & 6.35 & 10.45 & 12.76 & 8.84 & 10.42 & 13.11 & 10.12 & 10.82 & 8.79 & 9.82 & 11.64 & 11.49 \\
\hline $\mathrm{CaO}$ & 11.53 & 11.88 & 11.15 & 11.73 & 11.51 & 11.67 & 11.74 & 11.52 & 11.41 & 11.40 & 11.80 & 11.70 \\
\hline $\mathrm{Na} 2 \mathrm{O}$ & 2.99 & 2.87 & 3.12 & 2.71 & 3.01 & 3.00 & 2.88 & 3.00 & 3.03 & 3.17 & 2.85 & 2.88 \\
\hline $\mathrm{K} 2 \mathrm{O}$ & 0.42 & 0.56 & 0.62 & 0.63 & 0.39 & 0.59 & 0.39 & 0.42 & 0.45 & 0.43 & 0.60 & 0.64 \\
\hline $\mathrm{P} 2 \mathrm{O} 5$ & 0.00 & 0.00 & 0.00 & 0.00 & 0.00 & 0.00 & 0.00 & 0.00 & 0.00 & 0.00 & 0.00 & 0.00 \\
\hline $\mathrm{NiO}$ & 0.00 & 0.00 & 0.00 & 0.00 & 0.00 & 0.00 & 0.00 & 0.00 & 0.00 & 0.00 & 0.00 & 0.00 \\
\hline Total & 95.74 & 96.26 & 99.37 & 98.64 & 96.98 & 97.63 & 97.21 & 95.77 & 95.79 & 95.90 & 97.00 & 96.92 \\
\hline TAA B 26 & ILM3 & $\overline{\mathrm{ILM} 4}$ & ILM 8 & ILM 12 & ILM 17 & ILM 22 & ILM 30 & ILM 49 & ILM 61 & SPINEL $2 \mathrm{a}$ & SPINEL $2 b$ & SPINEL 19 \\
\hline $\mathrm{SiO} 2$ & 0.00 & 0.00 & 0.00 & 1.11 & 0.07 & 0.06 & 0.00 & 0.00 & 0.00 & 6.06 & 3.65 & 0.00 \\
\hline $\mathrm{TiO} 2$ & 51.87 & 53.82 & 53.57 & 53.58 & 52.67 & 51.97 & 53.89 & 53.55 & 53.93 & 17.70 & 18.86 & 9.89 \\
\hline $\mathrm{Al} 2 \mathrm{O} 3$ & 0.26 & 0.18 & 0.07 & 0.80 & 0.31 & 0.19 & 0.14 & 0.16 & 0.14 & 10.67 & 10.75 & 11.96 \\
\hline $\mathrm{Cr} 2 \mathrm{O} 3$ & 0.04 & 0.08 & 0.04 & 0.13 & 0.00 & 0.00 & 0.00 & 0.02 & 0.00 & 11.16 & 12.01 & 12.89 \\
\hline $\mathrm{FeO}$ & 42.93 & 42.61 & 36.94 & 37.11 & 40.39 & 42.52 & 41.04 & 38.71 & 40.34 & 43.71 & 46.66 & 55.93 \\
\hline MnO & 0.52 & 0.53 & 0.48 & 0.46 & 0.46 & 0.56 & 0.58 & 0.59 & 0.47 & 0.29 & 0.46 & 0.43 \\
\hline $\mathrm{MgO}$ & 4.62 & 4.67 & 7.76 & 8.03 & 6.03 & 4.86 & 5.94 & 7.31 & 6.27 & 7.92 & 8.06 & 7.58 \\
\hline $\mathrm{CaO}$ & 0.32 & 0.03 & 0.20 & 0.55 & 0.25 & 0.09 & 0.35 & 0.31 & 0.31 & 3.29 & 2.06 & 0.08 \\
\hline $\mathrm{Na} 2 \mathrm{O}$ & 0.00 & 0.00 & 0.00 & 0.00 & 0.00 & 0.00 & 0.00 & 0.00 & 0.00 & 0.00 & 0.00 & 0.00 \\
\hline $\mathrm{K} 2 \mathrm{O}$ & 0.00 & 0.00 & 0.00 & 0.00 & 0.00 & 0.00 & 0.00 & 0.00 & 0.00 & 0.00 & 0.00 & 0.00 \\
\hline $\mathrm{P} 2 \mathrm{O} 5$ & 0.00 & 0.00 & 0.00 & 0.00 & 0.00 & 0.00 & 0.00 & 0.00 & 0.00 & 0.00 & 0.00 & 0.00 \\
\hline $\mathrm{NiO}$ & 0.01 & 0.03 & 0.00 & 0.00 & 0.02 & 0.00 & 0.00 & 0.00 & 0.03 & 0.15 & 0.20 & 0.44 \\
\hline Total & 100.56 & 101.95 & 99.06 & 101.76 & 100.20 & 100.24 & 101.94 & 100.64 & 101.48 & 100.94 & 102.69 & 99.20 \\
\hline
\end{tabular}


APPENDIX TABLE 4: Major element compositions of daughter mineral

\begin{tabular}{|c|c|c|c|c|c|c|c|c|c|c|c|c|}
\hline MAG B 47 & Ti-MNT 21 & $\overline{\text { ILM } 45}$ & ILM 64 & SPINEL 4 & SPINEL 6 & SPINEL 8 & SPINEL 9 & SPINEL 11 & SPINEL 11 in 01 & SPINEL 13 & SPINEL 15 & SPINEL c 19 \\
\hline $\mathrm{SiO} 2$ & 0.13 & 0.48 & 0.08 & 0.09 & 0.00 & 0.00 & 0.05 & 0.00 & 0.00 & 0.00 & 0.00 & 0.14 \\
\hline $\mathrm{TiO} 2$ & 29.83 & 54.02 & 52.90 & 3.33 & 3.80 & 4.57 & 3.12 & 3.37 & 2.27 & 7.14 & 2.93 & 7.54 \\
\hline $\mathrm{Al} 2 \mathrm{O} 3$ & 2.40 & 0.27 & 0.02 & 18.96 & 15.99 & 18.35 & 18.16 & 15.48 & 14.71 & 16.27 & 14.85 & 17.97 \\
\hline $\mathrm{Cr} 2 \mathrm{O} 3$ & 0.07 & 0.34 & 0.00 & 40.33 & 40.57 & 36.67 & 42.65 & 42.78 & 44.78 & 33.00 & 40.14 & 33.81 \\
\hline $\mathrm{FeO}$ & 62.74 & 37.81 & 40.27 & 26.16 & 31.66 & 32.57 & 26.62 & 30.84 & 27.72 & 33.09 & 32.27 & 33.62 \\
\hline $\mathrm{MnO}$ & 0.88 & 0.73 & 0.72 & 0.34 & 0.46 & 0.54 & 0.36 & 0.58 & 0.37 & 0.52 & 0.47 & 0.44 \\
\hline MgO & 1.15 & 5.53 & 5.05 & 9.72 & 8.01 & 7.54 & 9.44 & 7.37 & 12.24 & 8.39 & 8.24 & 7.09 \\
\hline $\mathrm{CaO}$ & 0.09 & 0.58 & 0.07 & 0.11 & 0.25 & 0.29 & 0.21 & 0.24 & 0.08 & 0.20 & 0.18 & 0.09 \\
\hline $\mathrm{Na} 2 \mathrm{O}$ & 0.00 & 0.00 & 0.00 & 0.00 & 0.00 & 0.00 & 0.00 & 0.00 & 0.00 & 0.00 & 0.00 & 0.00 \\
\hline $\mathrm{K} 2 \mathrm{O}$ & 0.00 & 0.00 & 0.00 & 0.00 & 0.00 & 0.00 & 0.00 & 0.00 & 0.00 & 0.00 & 0.00 & 0.00 \\
\hline $\mathrm{P} 2 \mathrm{O} 5$ & 0.00 & 0.00 & 0.00 & 0.00 & 0.00 & 0,00 & 0.00 & 0.00 & 0.00 & 0.00 & 0.00 & 0.00 \\
\hline $\mathrm{NiO}$ & 0.06 & 0.00 & 0.05 & 0.07 & 0.27 & 0.28 & 0.04 & 0.30 & 0.38 & 0.28 & 0.29 & 0.07 \\
\hline Total & 97.36 & 99.76 & 99.14 & 99.12 & 101.01 & 100.80 & 100.65 & 100.96 & 102.55 & 98.89 & 99.36 & 100.77 \\
\hline
\end{tabular}

\begin{tabular}{|c|c|c|c|c|c|c|c|c|c|c|c|c|}
\hline$\overline{M A G B 25}$ & AMPH 24 & AMPH 25 & AMPH 27 & AMPH 28 & AMPH 30 & AMPH 31 & AMPH 34 & AMPH 35 & AMPH 37 & AMPH 40 & AMPH $40 \mathrm{~A}$ & AMPH 41 \\
\hline $\mathrm{SiO} 2$ & 37.60 & 36.80 & 37.58 & 36.97 & 39.45 & 37.66 & 37.70 & 37.91 & 39.98 & 39.53 & 42.18 & 36.54 \\
\hline $\mathrm{TiO} 2$ & 4.67 & 4.29 & 4.82 & 4.16 & 5.88 & 2.87 & 4.36 & 5.88 & 4.66 & 5.00 & 4.50 & 4.98 \\
\hline $\mathrm{A} 12 \mathrm{O} 3$ & 16.36 & 16.01 & 14.73 & 16.37 & 13.74 & 16.46 & 14.79 & 15.23 & 13.78 & 13.35 & 11.01 & 16.38 \\
\hline $\mathrm{Cr} 2 \mathrm{O} 3$ & 0.01 & 0.01 & 0.03 & 0.00 & 0.05 & 0.02 & 0.06 & 0.05 & 0.07 & 0.00 & 0.09 & 0.00 \\
\hline $\mathrm{FeO}$ & 13.29 & 15.10 & 13.03 & 14.69 & 10.87 & 14.62 & 15.12 & 10.38 & 13.96 & 12.29 & 10.20 & 14.79 \\
\hline MnO & 0.23 & 0.31 & 0.27 & 0.24 & 0.15 & 0.28 & 0.20 & 0.18 & 0.18 & 0.21 & 0.15 & 0.27 \\
\hline $\mathrm{MgO}$ & 10.12 & 9.00 & 10.74 & 8.70 & 12.19 & 9.20 & 9.17 & 12.33 & 10.43 & 11.85 & 10.44 & 8.80 \\
\hline $\mathrm{CaO}$ & 11,70 & 11.38 & 11.82 & 11.20 & 12.04 & 11.59 & 12.18 & 11.39 & 11.58 & 11.54 & 18.38 & 11.46 \\
\hline $\mathrm{Na} 2 \mathrm{O}$ & 2.88 & 3.06 & 3.07 & 3.02 & 2.88 & 3.02 & 3.06 & 3.05 & 2.92 & 3.01 & 1.18 & 2.95 \\
\hline $\mathrm{K} 2 \mathrm{O}$ & 0.49 & 0.45 & 0.42 & 0.47 & 0.45 & 0.51 & 0.49 & 0.47 & 0.53 & 0.50 & 0.20 & 0.51 \\
\hline P2O5 & 0.00 & 0.00 & 0.00 & 0.00 & 0.00 & 0.00 & 0.00 & 0.00 & 0.00 & 0.00 & 0.00 & 0.00 \\
\hline $\mathrm{NiO}$ & 0.00 & 0.00 & 0.00 & 0.00 & 0.00 & 0.00 & 0.00 & 0.00 & 0.00 & 0.00 & 0.00 & 0.00 \\
\hline Total & 97.35 & 96.41 & 96.51 & 95.81 & 97.69 & 96.23 & 97.11 & 96.84 & 98.09 & 97.27 & 98.34 & 96.68 \\
\hline
\end{tabular}

\begin{tabular}{|c|c|c|c|c|c|c|c|c|c|c|c|}
\hline TAA B 26 & SPINEL 22 & SPINEL 24a & SPINEL $24 \mathrm{~b}$ & SPINEL 38 & $\overline{P L A G} 40 \mathrm{a}$ & PLAG2 $40 \mathrm{~b}$ & PLAG 43 & PLAG 49 & $\overline{P L A G ~} 50$ & PLAG 55a & PLAG 55b \\
\hline $\mathrm{SiO} 2$ & 0.00 & 0.00 & 0.00 & 0.00 & 49.20 & 46.56 & 45.66 & 47.22 & 46.84 & 46.42 & 47.46 \\
\hline $\mathrm{TiO} 2$ & 17.14 & 23.07 & 21.98 & 18.72 & 0.00 & 0.00 & 0.00 & 0.00 & 0.00 & 0.00 & 0.00 \\
\hline $\mathrm{Al} 2 \mathrm{O} 3$ & 10.14 & 9.15 & 9.95 & 9.65 & 27.83 & 30.31 & 32.71 & 34.66 & 33.06 & 33.24 & 33.55 \\
\hline $\mathrm{Cr} 2 \mathrm{O} 3$ & 11.03 & 7.70 & 7.69 & 13.98 & 0.00 & 0.00 & 0.00 & 0.00 & 0.00 & 0.00 & 0.00 \\
\hline $\mathrm{FeO}$ & 54.16 & 54.11 & 55.62 & 50.89 & 1.01 & 1.01 & 1.25 & 0.89 & 0.73 & 1.34 & 0.76 \\
\hline $\mathrm{MnO}$ & 0.59 & 0.56 & 0.56 & 0.59 & 0.00 & 0.00 & 0.00 & 0.00 & 0.00 & 0.00 & 0.00 \\
\hline $\mathrm{MgO}$ & 6.00 & 6.35 & 5.44 & 6.33 & 0.46 & 0.49 & 0.22 & 0.15 & 0.05 & 0.19 & 0.10 \\
\hline $\mathrm{CaO}$ & 0.17 & 0.16 & 0.11 & 0.19 & 13.02 & 16.34 & 17.77 & 17.94 & 17.56 & 17.33 & 17.61 \\
\hline $\mathrm{Na} 2 \mathrm{O}$ & 0.00 & 0.00 & 0.00 & 0.00 & 2.28 & 2.03 & 1.17 & 1.20 & 1.43 & 1.49 & 1.58 \\
\hline $\mathrm{K} 2 \mathrm{O}$ & 0.00 & 0.00 & 0.00 & 0.00 & 2.15 & 0.20 & 0.18 & 0.09 & 0.17 & 0.11 & 0.15 \\
\hline $\mathrm{P} 2 \mathrm{O} 5$ & 0.00 & 0.00 & 0.00 & 0.00 & 0.00 & 0.00 & 0.00 & 0.00 & 0.00 & 0.00 & 0.00 \\
\hline $\mathrm{NiO}$ & 0.43 & 0.40 & 0.42 & 0.48 & 0.00 & 0.00 & 0.00 & 0.00 & 0.00 & 0.00 & 0.00 \\
\hline Total & 99.66 & 101.50 & 101.77 & 100.84 & 95.94 & 96.95 & 98.95 & 102.15 & 99.83 & 100.13 & 101.22 \\
\hline
\end{tabular}


APPENDIX TABLE 4: Major element compositions of daughter mineral

\begin{tabular}{|c|c|c|c|c|c|c|c|c|c|c|c|}
\hline MAG B 47 & SPINEL $\mathrm{m} 1 \mathrm{~S}$ & SPINEL 20 & SPINEL 32 & SPINEL 33A & SPINEL 33 & SPINEL in $\mathrm{Ol} 33$ & SPINEL 34 & SPINEL in ol 134 & SPINEL 41 & SPINEL 43 & SPINEL 45 \\
\hline $\mathrm{SiO} 2$ & 0.36 & 0.06 & 0.07 & 0.06 & 0.12 & 0.00 & 0.00 & 0.00 & 0.00 & 0.00 & 0.02 \\
\hline $\mathrm{TiO} 2$ & 19.19 & 18.56 & 3.28 & 3.74 & 3.64 & 2.56 & 3.11 & 2.07 & 2.47 & 3.32 & 7.55 \\
\hline $\mathrm{Al} 2 \mathrm{O} 3$ & 8.27 & 12.67 & 16.22 & 17.93 & 16.22 & 15.70 & 16.48 & 18.94 & 15.35 & 16.94 & 15.10 \\
\hline $\mathrm{Cr} 2 \mathrm{O} 3$ & 18.31 & 16.31 & 37.98 & 38.53 & 38.64 & 37.67 & 40.57 & 40.28 & 37.07 & 35.58 & 13.73 \\
\hline $\mathrm{FeO}$ & 41.73 & 41.97 & 33.87 & 31.14 & 32.65 & 32.19 & 28.36 & 26.14 & 33.82 & 33.81 & 50.95 \\
\hline $\mathrm{MnO}$ & 0.45 & 0.40 & 0.32 & 0.44 & 0.42 & 0.37 & 0.45 & 0.38 & 0.40 & 0.41 & 0.44 \\
\hline $\mathrm{MgO}$ & 9.41 & 10.61 & 9.67 & 7.65 & 8.48 & 10.17 & 9.17 & 11.57 & 10.49 & 10.16 & 10.64 \\
\hline $\mathrm{CaO}$ & 0.06 & 0.07 & 0.05 & 0.15 & 0.14 & 0.02 & 0.21 & 0.03 & 0.03 & 0.06 & 0.03 \\
\hline $\mathrm{Na} 2 \mathrm{O}$ & 0.00 & 0.00 & 0.00 & 0.00 & 0.00 & 0.00 & 0.00 & 0.00 & 0.00 & 0.00 & 0.00 \\
\hline $\mathrm{K} 2 \mathrm{O}$ & 0.00 & 0.00 & 0.00 & 0.00 & 0.00 & 0.00 & 0.00 & 0.00 & 0.00 & 0.00 & 0.00 \\
\hline $\mathrm{P} 2 \mathrm{O} 5$ & 0.00 & 0.00 & 0.00 & 0.00 & 0.00 & 0.00 & 0.00 & 0.00 & 0.00 & 0.00 & 0.00 \\
\hline $\mathrm{NiO}$ & 0.06 & 0.12 & 0.14 & 0.31 & 0.21 & 0.25 & 0.21 & 0.32 & 0.27 & 0.26 & 0.30 \\
\hline Total & 97.83 & 100.78 & 101.58 & 99.94 & 100.52 & 98.93 & 98.55 & 99.72 & 99.90 & 100.55 & 98.76 \\
\hline$\overline{M A G B ~} 25$ & AMPH 42 & AMPH 43 & AMPH 44 & AMPH 45 & AMPH 47 & AMPH 48 & AMPH 49 & AMPH 50 & AMPH 51 & $\overline{\mathrm{AMPH}} 53$ & AMPH 54 \\
\hline $\mathrm{SiO} 2$ & 36.68 & 39.23 & 35.32 & 36.06 & 41.30 & 39.04 & 39.13 & 36.62 & 37.86 & 41.11 & 37.79 \\
\hline $\mathrm{TiO} 2$ & 4.05 & 4.88 & 4.88 & 4.51 & 2.39 & 6.42 & 5.79 & 3.20 & 5.17 & 3.98 & 4.99 \\
\hline $\mathrm{Al} 2 \mathrm{O} 3$ & 16.93 & 13.78 & 16.82 & 17.00 & 10.78 & 11.92 & 13.50 & 18.55 & 16.53 & 13.24 & 14.38 \\
\hline $\mathrm{Cr} 2 \mathrm{O} 3$ & 0.07 & 0.00 & 0.03 & 0.02 & 0.00 & 0.13 & 0.00 & 0.00 & 0.05 & 0.00 & 0.01 \\
\hline $\mathrm{FeO}$ & 14.44 & 12.57 & 14.66 & 14.04 & 11.36 & 12.04 & 12.70 & 17.57 & 12.99 & 11.59 & 14.41 \\
\hline $\mathrm{MnO}$ & 0.24 & 0.13 & 0.20 & 0.22 & 0.17 & 0.16 & 0.14 & 0.34 & 0.20 & 0.15 & 0.20 \\
\hline $\mathrm{MgO}$ & 8.65 & 11.55 & 8.97 & 9.12 & 10.77 & 8.19 & 10.44 & 6.62 & 9.48 & 12.43 & 10.17 \\
\hline $\mathrm{CaO}$ & 11.76 & 11.27 & 11.67 & 11.31 & 16.77 & 18.10 & 11.60 & 11.11 & 11.67 & 11.54 & 11.63 \\
\hline $\mathrm{Na} 2 \mathrm{O}$ & 3.01 & 3.03 & 3.05 & 2.97 & 2.15 & 1.52 & 2.87 & 2.86 & 2.69 & 2.89 & 3.11 \\
\hline $\mathrm{K} 2 \mathrm{O}$ & 0.46 & 0.56 & 0.50 & 0.44 & 0.26 & 0.23 & 0.63 & 0.48 & 0.50 & 0.60 & 0.45 \\
\hline $\mathrm{P} 2 \mathrm{O} 5$ & 0.00 & 0.00 & 0.00 & 0.00 & 0.00 & 0.00 & 0.00 & 0.00 & 0.00 & 0.00 & 0.00 \\
\hline $\mathrm{NiO}$ & 0.00 & 0.00 & 0.00 & 0.00 & 0.00 & 0.00 & 0.00 & 0.00 & 0.00 & 0.00 & 0.00 \\
\hline Total & 96.27 & 96.99 & 96.10 & 95.69 & 95.94 & 97.74 & 96.80 & 97.34 & 97.13 & 97.53 & 97.13 \\
\hline
\end{tabular}


APPENDIX TABLE 4: Major element compositions of daughter mineral

\begin{tabular}{|c|c|c|c|c|c|c|c|c|c|c|c|}
\hline$\overline{M A G B} 47$ & SPINEL in O1 46 & SPINEL 51AC & SPINEL 51A $\mathrm{m}$ & SPINEL 52 & SPINEL I53 & SPINEL 54 & SPINEL63 & SPINEL 67 & PLAG 45A & PLAG 51 & BIOTITE 49 \\
\hline $\mathrm{SiO} 2$ & 0.07 & 0.00 & 0.11 & 0.06 & 0.00 & 0.05 & 0.00 & 0.04 & 66.73 & 65.66 & 34.18 \\
\hline $\mathrm{TiO} 2$ & 2.46 & 2.15 & 17.99 & 0.42 & 3.35 & 2.57 & 2.46 & 3.56 & 0.00 & 0.00 & 11.00 \\
\hline $\mathrm{Al} 2 \mathrm{O} 3$ & 15.19 & 15.36 & 5.97 & 20.54 & 15.83 & 14.12 & 15.19 & 15.11 & 19.27 & 20.72 & 13.83 \\
\hline $\mathrm{Cr} 2 \mathrm{O} 3$ & 36.13 & 41.65 & 17.72 & 45.38 & 41.81 & 42.54 & 40.45 & 37.57 & 0.00 & 0.00 & 0.00 \\
\hline $\mathrm{FeO}$ & 34.96 & 30.85 & 54.75 & 22.75 & 30.10 & 27.89 & 30.43 & 35.28 & 0.73 & 0.72 & 9.80 \\
\hline $\mathrm{MnO}$ & 0.25 & 0.34 & 0.75 & 0.30 & 0.55 & 0.31 & 0.98 & 0.34 & 0.00 & 0.00 & 0.07 \\
\hline $\mathrm{MgO}$ & 10.43 & 10.83 & 2.95 & 11.44 & 8.45 & 11.15 & 9.98 & 8.03 & 0.00 & 0.00 & 13.77 \\
\hline $\mathrm{CaO}$ & 0.00 & 0.02 & 0.04 & 0.02 & 0.29 & 0.14 & 0.13 & 0.04 & 0.11 & 0.23 & 0.40 \\
\hline $\mathrm{Na} 2 \mathrm{O}$ & 0.00 & 0.00 & 0.00 & 0.00 & 0.00 & 0.00 & 0.00 & 0.00 & 4.85 & 4.71 & 0.47 \\
\hline $\mathrm{K} 2 \mathrm{O}$ & 0.00 & 0.00 & 0.00 & 0.00 & 0.00 & 0.00 & 0.00 & 0.00 & 8.69 & 7.67 & 7.81 \\
\hline $\mathrm{P} 2 \mathrm{O} 5$ & 0.00 & 0.00 & 0.00 & 0.00 & 0.00 & 0.00 & 0.00 & 0.00 & 0.00 & 0.00 & 0.00 \\
\hline $\mathrm{NiO}$ & 0.10 & 0.27 & 0.19 & 0.08 & 0.26 & 0.15 & 0.59 & 0.13 & 0.00 & 0.00 & 0.00 \\
\hline Total & 99.60 & 101.46 & 100.46 & 100.99 & 100.63 & 98.91 & 100.20 & 100.10 & 100.37 & 99.70 & 91.31 \\
\hline MAG B 25 & Ti-MNT 1 & Ti-MNT 4 & Ti-MNT 5 & T3-MNT 6 & Ti-MNT 8 & TinMN 9 & Ti-MNT 10 & Ti-MNT 13 & Ti-MNT 15 & Ti-MNT 18 & Ti-MNT 24 \\
\hline $\mathrm{SiO} 2$ & 0.19 & 0.09 & 0.12 & 0.41 & 0.12 & 0.16 & 0.11 & 0.14 & 4.77 & 0.12 & 0.12 \\
\hline $\mathrm{TiO} 2$ & 15.23 & 16.33 & 17.15 & 20.49 & 15.51 & 17.73 & 14.91 & 16.42 & 14.06 & 16.88 & 17.13 \\
\hline $\mathrm{Al} 2 \mathrm{O} 3$ & 8.81 & 8.52 & 7.97 & 6.08 & 8.30 & 7.91 & 8.45 & 6.75 & 5.66 & 8.14 & 8.02 \\
\hline $\mathrm{Cr} 2 \mathrm{O} 3$ & 0.03 & 0.05 & 0.09 & 0.07 & 0.03 & 0.02 & 0.05 & 0.05 & 0.07 & 0.04 & 0.03 \\
\hline $\mathrm{FeO}$ & 71.35 & 70.06 & 71.58 & 66.23 & 71.67 & 68.84 & 71.79 & 71.68 & 69.20 & 70.68 & 70.02 \\
\hline $\mathrm{MnO}$ & 0.73 & 1.13 & 0.89 & 1.06 & 0.93 & 0.54 & 0.54 & 0.59 & 0.75 & 0.80 & 0.67 \\
\hline $\mathrm{MgO}$ & 1.39 & 2.24 & 2.53 & 2.25 & 3.01 & 2.47 & 2.62 & 2.67 & 5.19 & 1.66 & 2.04 \\
\hline $\mathrm{CaO}$ & 0.33 & 0.37 & 0.24 & 0.19 & 0.19 & 0.37 & 0.28 & 0.06 & 0.10 & 0.12 & 0.19 \\
\hline $\mathrm{Na} 2 \mathrm{O}$ & 0.00 & 0.00 & 0.00 & 0.00 & 0.00 & 0.00 & 0.00 & 0,00 & 0.00 & 0.00 & 0.00 \\
\hline $\mathrm{K} 2 \mathrm{O}$ & 0.00 & 0.00 & 0.00 & 0.00 & 0.00 & 0.00 & 0.00 & 0.00 & 0.00 & 0.00 & 0.00 \\
\hline P2O5 & 0.00 & 0.00 & 0.00 & 0.00 & 0.00 & 0.00 & 0.00 & 0.00 & 0.00 & 0.00 & 0.00 \\
\hline $\mathrm{NiO}$ & 0.00 & 0.35 & 0.26 & 0.30 & 0.40 & 0.00 & 0.00 & 0.02 & 0.09 & 0.02 & 0.04 \\
\hline Total & 98.06 & 96.26 & 99.37 & 97.06 & 96.98 & 97.63 & 97.21 & 95.77 & 95.79 & 95.90 & 97.00 \\
\hline
\end{tabular}


APPENDIX TABLE 4: Major element compositions of daughter mineral

\begin{tabular}{|c|c|c|c|c|c|c|c|c|}
\hline MAG B 47 & BIOTTTE 51A & BIOTITE & 54 APATTTE & 52 APATITE & 54 APATITE & 61 SPHENE 16 & SPHENE 31 & SPHENE 53 \\
\hline $\mathrm{SiO} 2$ & 43.86 & 35.50 & 4.86 & 2.33 & 2.67 & 31.05 & 30.50 & 30.95 \\
\hline $\mathrm{TiO} 2$ & 4.11 & 1.02 & 0.00 & 0.00 & 0.00 & 31.75 & 36.95 & 34.55 \\
\hline $\mathrm{Al} 2 \mathrm{O} 3$ & 13.11 & 18.37 & 2.45 & 0.66 & 0.51 & 5.06 & 1.89 & 3.83 \\
\hline $\mathrm{Cr} 2 \mathrm{O} 3$ & 0.10 & 0.00 & 0.00 & 0.00 & 0.00 & 0.00 & 0.00 & 0.00 \\
\hline $\mathrm{FeO}$ & 9.81 & 13.08 & 1.08 & 1.13 & 1.04 & 1.37 & 0.85 & 0.69 \\
\hline $\mathrm{MnO}$ & 0.12 & 0.15 & 0.00 & 0.00 & 0.00 & 0.00 & 0.00 & 0.00 \\
\hline $\mathrm{MgO}$ & 17.30 & 16.54 & 0.86 & 1.87 & 0.78 & 0.32 & 0.00 & 2.55 \\
\hline $\mathrm{CaO}$ & 0.06 & 0.08 & 49.33 & 50.94 & 51.53 & 29.32 & 29.16 & 27.41 \\
\hline $\mathrm{Na} 2 \mathrm{O}$ & 0.80 & 0.29 & 0.00 & 0.00 & 0.00 & 0.05 & 0.02 & 0.00 \\
\hline $\mathrm{K} 2 \mathrm{O}$ & 8.46 & 7.46 & 0.00 & 0.00 & 0.00 & 0.00 & 0.00 & 0.00 \\
\hline $\mathrm{P} 2 \mathrm{O} 5$ & 0.11 & 0.00 & 33.59 & 0.00 & 36.57 & 0.00 & 0.00 & 0.00 \\
\hline $\mathrm{NiO}$ & 0.00 & 0.10 & 0.00 & 0.00 & 0.00 & 0.00 & 0.00 & 0.00 \\
\hline Total & 97.84 & 92.58 & 92.17 & 56.92 & 93.09 & 98.92 & 99.37 & 99.98 \\
\hline
\end{tabular}

\begin{tabular}{|c|c|c|c|c|c|c|c|c|c|c|c|c|}
\hline MAG B 25 & Ti-MNT 25 & T1-MNT 27 & Ti-MNT 28 & Ti-MNT 35 & Ti-MNT 35 & Ti-MNT 38 & Ti-MNT 40 & Ti-MNT 42 & Ti-MNT 44 & Ti-MNT 48 & Ti-MNT 53 & Ti-MNT 54 \\
\hline $\mathrm{SiO} 2$ & 0.14 & 0.47 & 0.11 & 0.10 & 0.89 & 0.19 & 0.91 & 0.15 & 0.19 & 1.14 & 1.90 & 5.70 \\
\hline $\mathrm{TiO} 2$ & 15.89 & 20.20 & 17.23 & 15.09 & 13.98 & 12.92 & 17.90 & 16.93 & 16.62 & 20.46 & 16.53 & 26.15 \\
\hline $\mathrm{Al} 2 \mathrm{O} 3$ & 7.21 & 7.70 & 7.71 & 8.11 & 9.04 & 10.34 & 5.47 & 8.86 & 8.33 & 4.22 & 6.99 & 4.63 \\
\hline $\mathrm{Cr} 2 \mathrm{O} 3$ & 0.05 & 0.03 & 0.04 & 0.06 & 0.04 & 0.06 & 0.10 & 0.04 & 0.05 & 0.12 & 0.52 & 0.01 \\
\hline $\mathrm{FeO}$ & 70.54 & 65.83 & 70.48 & 70.35 & 69.31 & 71.20 & 69.49 & 71.09 & 68.33 & 70.83 & 67.46 & 54.55 \\
\hline $\mathrm{MnO}$ & 0.42 & 0.70 & 0.51 & 0.46 & 0.33 & 0.48 & 0.51 & 0.58 & 0.50 & 0.79 & 0.34 & 0.31 \\
\hline $\mathrm{MgO}$ & 3.78 & 1.40 & 1.68 & 2.72 & 2.30 & 2.11 & 2.01 & 1.41 & 1.98 & 0.15 & 2.52 & 1.92 \\
\hline $\mathrm{CaO}$ & 0.14 & 0.25 & 0.17 & 0.19 & 0.36 & 0.35 & 0.58 & 0.21 & 0.58 & 0.37 & 0.30 & 0.91 \\
\hline $\mathrm{Na} 2 \mathrm{O}$ & 0.00 & 0.00 & 0.00 & 0.00 & 0.00 & 0.00 & 0.00 & 0.00 & 0.00 & 0.00 & 0.00 & 0.00 \\
\hline $\mathrm{K} 2 \mathrm{O}$ & 0.00 & 0.00 & 0.00 & 0.00 & 0.00 & 0.00 & 0.00 & 0.00 & 0.00 & 0.00 & 0.00 & 0.00 \\
\hline $\mathrm{P} 2 \mathrm{O} 5$ & 0.00 & 0.00 & 0.00 & 0.00 & 0.00 & 0.00 & 0.00 & 0.00 & 0.00 & 0.00 & 0.00 & 0.00 \\
\hline $\mathrm{NiO}$ & 0.04 & 0.00 & 0.00 & 0.00 & 0.00 & 0.00 & 0.00 & 0.00 & 0.00 & 0.00 & 0.00 & 0.00 \\
\hline Total & 96.92 & 97.35 & 96.41 & 96.51 & 95.81 & 97.69 & 96.95 & 97.11 & 96.84 & 98.09 & 97.27 & 94.17 \\
\hline
\end{tabular}

\begin{tabular}{|c|ccccccc|}
\hline MAG B 25 & ILM 16 & ILM 34 & ILM 52 & SPINEL 7 & SPINEL 55 & PLAG 5 & PLAG 23 \\
\hline SiO2 & 0.21 & 11.24 & 5.58 & 0.00 & 0.07 & 59.57 & 58.33 \\
$\mathrm{TiO2}$ & 47.24 & 38.24 & 44.86 & 5.72 & 3.05 & 0.00 & 0.00 \\
$\mathrm{Al2O3}$ & 0.39 & 3.59 & 2.30 & 16.30 & 17.22 & 22.30 & 26.64 \\
$\mathrm{Cr} 203$ & 0.03 & 0.00 & 0.34 & 20.13 & 30.56 & 0.00 & 0.00 \\
$\mathrm{FeO}$ & 49.48 & 40.32 & 43.36 & 46.69 & 38.94 & 0.97 & 0.81 \\
$\mathrm{MnO}$ & 1.06 & 0.50 & 0.72 & 0.88 & 0.27 & 0.00 & 0.00 \\
$\mathrm{MgO}$ & 0.46 & 2.28 & 1.76 & 9.19 & 9.53 & 0.04 & 0.07 \\
$\mathrm{CaO}$ & 0.35 & 4.56 & 2.03 & 0.19 & 0.08 & 2.67 & 7.81 \\
$\mathrm{Na2O}$ & 0.00 & 0.00 & 0.00 & 0.00 & 0.00 & 3.00 & 6.70 \\
$\mathrm{~K} 2 \mathrm{O}$ & 0.00 & 0.00 & 0.00 & 0.00 & 0.00 & 1.92 & 0.50 \\
$\mathrm{P} 2 \mathrm{O5}$ & 0.00 & 0.00 & 0.00 & 0.00 & 0.00 & 0.00 & 0.00 \\
$\mathrm{NiO}$ & 0.02 & 0.00 & 0.00 & 0.78 & 0.14 & 0.00 & 0.00 \\
Total & 96.68 & 96.27 & 96.99 & 96.10 & 95.69 & 95.94 & 97.74 \\
\hline
\end{tabular}


APPENDIX TABLE 5: Major element compositions of carbonate globules

\begin{tabular}{|c|cccccccccccc|}
\hline MAGB25 & $4 \mathrm{a}$ & $4 \mathrm{~b}$ & $5 \mathrm{a}$ & $9 \mathrm{a}$ & $9 \mathrm{~b}$ & $10 \mathrm{a}$ & $10 \mathrm{~b}$ & $10 \mathrm{c}$ & $11 \mathrm{a}$ & $20 \mathrm{a}$ & $25 \mathrm{a}$ & $25 \mathrm{~b}$ \\
\hline $\mathrm{SiO} 2$ & 0.19 & 0.06 & 0.06 & 0.05 & 0.12 & 0.00 & 0.00 & 0.05 & 0.02 & 3.87 & 0.10 & 0.10 \\
$\mathrm{FeO}$ & 14.73 & 41.22 & 33.87 & 10.37 & 37.02 & 39.16 & 12.34 & 12.09 & 31.72 & 42.45 & 34.08 & 43.10 \\
$\mathrm{MnO}$ & 1.99 & 2.26 & 3.14 & 0.41 & 0.85 & 1.64 & 0.28 & 6.42 & 0.55 & 0.88 & 1.23 & 1.20 \\
$\mathrm{MgO}$ & 4.05 & 6.03 & 8.94 & 34.62 & 11.67 & 8.16 & 34.56 & 11.10 & 4.72 & 3.39 & 8.25 & 7.12 \\
$\mathrm{CaO}$ & 36.10 & 7.20 & 11.54 & 7.08 & 6.09 & 6.48 & 5.05 & 23.79 & 19.02 & 9.48 & 15.32 & 9.06 \\
$\mathrm{Na} 2 \mathrm{O}$ & 0.08 & 0.10 & 0.14 & 0.22 & 0.18 & 0.12 & 0.21 & 0.28 & 0.17 & 0.19 & 0.30 & 0.12 \\
$\mathrm{SrO}$ & 0.11 & 0.05 & 0.02 & 0.00 & 0.00 & 0.00 & 0.00 & 0.00 & 0.07 & 0.06 & 0.00 & 0.00 \\
$\mathrm{BaO}$ & 0.00 & 0.07 & 0.02 & 0.00 & 0.01 & 0.00 & 0.00 & 0.00 & 0.01 & 0.01 & 0.11 & 0.08 \\
$\mathrm{CO} 2$ & 43.40 & 39.09 & 41.71 & 50.20 & 41.03 & 39.09 & 49.57 & 42.45 & 40.03 & 43.52 & 43.07 & 42.28 \\
$\mathrm{Total}$ & 100.65 & 96.09 & 99.43 & 102.96 & 96.97 & 94.65 & 102.00 & 96.18 & 96.31 & 103.85 & 102.48 & 103.05 \\
\hline
\end{tabular}

\begin{tabular}{|c|ccccccc|}
\hline MAGB25 & $25 \mathrm{c}$ & $25 \mathrm{~d}$ & $25 \mathrm{e}$ & $32 \mathrm{a}$ & $35 \mathrm{a}$ & $36 \mathrm{a}$ & $44 \mathrm{a}$ \\
\hline $\mathrm{SiO} 2$ & 0.05 & 0.71 & 0.10 & 0.03 & 3.00 & 0.09 & 0.11 \\
$\mathrm{FeO}$ & 17.38 & 26.86 & 30.27 & 28.97 & 46.39 & 13.94 & 0.87 \\
$\mathrm{MnO}$ & 0.26 & 0.46 & 0.66 & 0.56 & 0.81 & 3.08 & 0.78 \\
$\mathrm{MgO}$ & 30.49 & 11.09 & 13.91 & 2.39 & 4.12 & 8.01 & 1.01 \\
$\mathrm{CaO}$ & 4.25 & 18.20 & 12.85 & 24.67 & 4.61 & 29.42 & 51.91 \\
$\mathrm{Na} 2 \mathrm{O}$ & 0.42 & 0.15 & 0.20 & 0.09 & 0.23 & 0.28 & 0.06 \\
$\mathrm{SrO}$ & 0.02 & 0.05 & 0.12 & 0.10 & 0.01 & 0.04 & 0.07 \\
$\mathrm{BaO}$ & 0.03 & 0.04 & 0.05 & 0.04 & 0.00 & 0.00 & 0.00 \\
$\mathrm{CO} 2$ & 47.80 & 44.31 & 44.58 & 40.23 & 41.59 & 42.62 & 43.10 \\
$\mathrm{Total}$ & 100.68 & 101.86 & 102.74 & 97.09 & 100.75 & 97.47 & 97.91 \\
\hline
\end{tabular}


APPENDIX TABLE 6: Major element compositions of sulfides

\begin{tabular}{|c|cccc|}
\hline MAGB47 & $42 \mathrm{a}$ & $68 \mathrm{a}$ & $70 \mathrm{a}$ & $70 \mathrm{~b}$ \\
\hline. $\mathrm{Fe}$ & 33.57 & 58.28 & 60.01 & 32.69 \\
$\mathrm{Co}$ & 0.68 & 0.18 & 0.13 & 0.93 \\
$\mathrm{Ni}$ & 31.59 & 2.16 & 0.32 & 32.11 \\
$\mathrm{Cu}$ & 0.27 & 0.22 & 0.16 & 0.28 \\
$\mathrm{Zn}$ & 0.21 & 0.12 & 0.18 & 0.16 \\
$\mathrm{~Pb}$ & 0.00 & 0.00 & 0.00 & 0.00 \\
$\mathrm{~S}$ & 33.03 & 37.95 & 39.39 & 33.65 \\
Total & 99.34 & 98.90 & 100.20 & 99.81 \\
\hline
\end{tabular}

\begin{tabular}{|c|c|c|c|c|c|c|c|c|c|c|c|c|c|c|c|c|c|c|}
\hline $\mathrm{MAGB25}$ & $1 \mathrm{a}$ & $1 b$ & $1 \mathrm{c}$ & $5 a$ & $5 b$ & $12 \mathrm{a}$ & $13 a$ & $16 a$ & $25 a$ & $25 \mathrm{~b}$ & $28 \mathrm{a}$ & $28 \mathrm{~b}$ & $28 \mathrm{c}$ & $32 a$ & $32 b$ & $33 a$ & $36 a$ & $42 a$ \\
\hline $\mathrm{Fe}$ & 39.98 & 40.05 & 59.48 & 44.58 & 43.85 & 58.79 & 32.56 & 61.77 & 45.03 & 44.79 & 48.78 & 56.87 & 56.14 & 46.11 & 45.11 & 45.87 & 33.04 & 58.79 \\
\hline $\mathrm{Co}$ & 0.13 & 0.07 & 0.09 & 0.28 & 0.23 & 0.05 & 0.05 & 0.09 & 0.09 & 0.13 & 0.09 & 0.37 & 0.16 & 0.11 & 0.67 & 0.08 & 0.16 & 0.03 \\
\hline $\mathrm{Ni}$ & 0.33 & 0.55 & 0.06 & 0.80 & 0.83 & 0.13 & 0.51 & 0.19 & 0.64 & 0.86 & 0.34 & 0.63 & 0.34 & 0.09 & 0.48 & 0.04 & 0.67 & 0.10 \\
\hline $\mathrm{Cu}$ & 22.07 & 21.73 & 0.06 & 0.22 & 0.32 & 0.03 & 30.22 & 0.10 & 0.11 & 0.30 & 9.08 & 1.93 & 0.65 & 0.01 & 0.00 & 0.04 & 23.64 & 0.04 \\
\hline $\mathrm{Zn}$ & 0.15 & 0.03 & 0.03 & 0.00 & 0.00 & 0.04 & 0.22 & 0.00 & 0.00 & 0.02 & 0.04 & 0.04 & 0.01 & 0.01 & 0.00 & 0.00 & 0.06 & 0.07 \\
\hline $\mathrm{Pb}$ & 0.18 & 0.11 & 0.08 & 0.00 & 0.00 & 0.11 & 0.06 & 0.00 & 0.00 & 0.00 & 0.00 & 0.00 & 0.00 & 0.04 & 0.00 & 0.00 & 0.00 & 0.00 \\
\hline$S$ & 35.58 & 35.70 & 37.52 & 50.08 & 51.10 & 36.43 & 33.64 & 32.36 & 52.87 & 54.22 & 39.06 & 38.97 & 39.19 & 51.45 & 52.74 & 51.42 & 36.92 & 36.49 \\
\hline Total & 98.42 & 98.25 & 97.32 & 95.95 & 96.33 & 95.57 & 97.26 & 94.51 & 98.75 & 100.33 & 97.40 & 98.80 & 96.50 & 97.82 & 99.02 & 97.44 & 94.49 & 95.53 \\
\hline
\end{tabular}

\begin{tabular}{|c|cccccc|}
\hline TAAB26 & $14 \mathrm{a}$ & $15 \mathrm{a}$ & $34 \mathrm{a}$ & $34 \mathrm{~b}$ & $38 \mathrm{a}$ & $52 \mathrm{a}$ \\
\hline $\mathrm{Fe}$ & 55.79 & 44.64 & 58.37 & 58.93 & 56.63 & 30.76 \\
$\mathrm{Co}$ & 0.14 & 0.50 & 0.13 & 0.14 & 0.21 & 0.08 \\
$\mathrm{Ni}$ & 0.59 & 12.83 & 0.88 & 0.41 & 1.60 & 0.52 \\
$\mathrm{Cu}$ & 0.36 & 0.19 & 0.11 & 0.07 & 0.22 & 30.00 \\
$\mathrm{Zn}$ & 0.09 & 0.11 & 0.08 & 0.02 & 0.12 & 0.21 \\
$\mathrm{~Pb}$ & 0.00 & 0.00 & 0.10 & 0.06 & 0.00 & 0.00 \\
$\mathrm{~S}$ & 37.55 & 35.84 & 39.57 & 38.64 & 38.14 & 34.58 \\
Total & 94.52 & 94.12 & 99.23 & 98.26 & 96.91 & 96.15 \\
\hline
\end{tabular}


APPENDIX TABLE 7:Trace element compositions of melt inclusions

\begin{tabular}{|c|c|c|c|c|c|c|c|c|c|c|c|}
\hline MAGB47 & $13 \mathrm{a}$ & $13 \mathrm{~b}$ & $16 a$ & $18 \mathrm{a}$ & $21 \mathrm{a} \mathrm{cpx}$ & $25 \mathrm{a}$ & $38 \mathrm{a}$ & $39 a$ & $44 a$ & $44 b$ & $45 \mathrm{Aa}$ \\
\hline $\mathrm{Rb}$ & 3.48 & 8.00 & 1.81 & 15.68 & 1.40 & 5.40 & 21.22 & 8.50 & 8.87 & 2.61 & 34.56 \\
\hline $\mathrm{Ba}$ & 1.74 & 193.42 & 0.07 & 765.99 & 0.10 & 1.85 & 522.82 & 235.66 & 8500.68 & 3311.41 & 5295.27 \\
\hline $\mathrm{Nb}$ & 4.13 & 72.65 & 0.03 & 207.27 & 0.88 & 0.33 & 92.76 & 31.56 & 184.60 & 22.73 & 27.04 \\
\hline $\mathrm{La}$ & 0.55 & 70.16 & 0.02 & 44.84 & 2.00 & 0.45 & 60.15 & 7.51 & 61.18 & 58.32 & 41.25 \\
\hline $\mathrm{Ce}$ & 0.65 & 137.53 & 0.02 & 104.30 & 6.54 & 0.44 & 121.49 & 18.11 & 125.96 & 114.80 & 62.27 \\
\hline $\mathrm{Sr}$ & 10.05 & 3276.29 & 0.34 & 2096.13 & 50.23 & 8.64 & 473.09 & 148.45 & 1810.12 & 295.09 & 825.82 \\
\hline Nd & 0.23 & 85.52 & 0.11 & 55.13 & 6.78 & 0.22 & 54.40 & 9.79 & 60.22 & 55.00 & 26.62 \\
\hline $\mathrm{Sm}$ & 0.09 & 17.89 & 0.15 & 11.35 & 2.41 & 0.03 & 10.74 & 2.19 & 13.48 & 11.41 & 4.28 \\
\hline $\mathrm{Zr}$ & 30.22 & 427.48 & 0.69 & 284.56 & 41.65 & 2.94 & 303.59 & 97.58 & 282.31 & 279.31 & 56.42 \\
\hline $\mathrm{Hf}$ & 0.43 & 8.36 & 0.12 & 6.47 & 1.22 & 0.06 & 7.90 & 1.60 & 7.00 & 6.54 & 6.78 \\
\hline $\mathrm{Eu}$ & 0.04 & 6.94 & 0.02 & 4.59 & 0.60 & 0.01 & 1.26 & 0.89 & & & 4.55 \\
\hline $\mathrm{Ti}$ & 1833.47 & 22747.72 & 92.04 & 42314.17 & 5744.25 & 90.54 & 19245.94 & 6877.13 & 38226.08 & 18353.15 & 704.87 \\
\hline $\mathrm{Gd}$ & 0.08 & 20.41 & 0.05 & 13.57 & 2.12 & 0.06 & 6.22 & 2.15 & 8.95 & 6.94 & 6.34 \\
\hline Dy & 0.14 & 12.04 & 0.08 & 8.31 & 2.02 & 0.05 & 7.18 & 1.66 & 9.87 & 7.11 & 4.18 \\
\hline $\mathbf{Y}$ & 2.37 & 58.73 & 0.16 & 38.66 & 9.94 & 1.05 & 31.97 & 9.02 & 44.67 & 30.99 & 15.22 \\
\hline$E_{T}$ & 0.19 & 5.13 & 0.13 & 4.02 & 0.93 & 0.06 & 3.61 & 0.72 & 12.67 & 7.74 & 1.01 \\
\hline $\mathrm{Yb}$ & 0.16 & 3.08 & 0.11 & 2.49 & 0.49 & 0.08 & 1.89 & 0.64 & 2.73 & 1.97 & 0.56 \\
\hline $\mathrm{Li}$ & 1.41 & 5.66 & 1.74 & 14.27 & 11.96 & 0.48 & 11.85 & 3.64 & 0.90 & 2.78 & 10.21 \\
\hline $\mathrm{Be}$ & 0.75 & 1.85 & 0.01 & 2.15 & 0.11 & 0.69 & 5.05 & 1.65 & 2.95 & 3.30 & 2.18 \\
\hline $\mathrm{Sc}$ & 14.39 & 39.41 & 4.98 & 31.36 & 117.60 & 33.57 & 22.89 & 21.67 & 26.74 & 17.67 & 24.06 \\
\hline $\mathrm{Cr}$ & 252.90 & 575.10 & 389.18 & 164.53 & 5036.82 & 553.06 & 168.72 & 254.74 & 140.11 & 85.14 & 20.34 \\
\hline MAGB25 & $1 \mathrm{a}$ & $4 a$ & $5 a$ & $8 \mathrm{a}$ & $9 \mathrm{a}$ & $9 \mathrm{bcpx}$ & $11 \mathrm{Aa}$ & 122 & $16 a$ & $25 \mathrm{a}$ & $25 \mathrm{~b}$ \\
\hline $\mathrm{Rb}$ & 32.39 & 2.21 & 6.18 & 35.19 & 3.65 & 1.03 & 44.63 & 7.38 & 26.52 & 26.57 & 2.76 \\
\hline $\mathrm{Ba}$ & 587.39 & 293.24 & 131.38 & 733.09 & 177.55 & 0.13 & 722.34 & 16.98 & 585.83 & 523.93 & 144.59 \\
\hline $\mathrm{Nb}$ & 48.94 & 5.75 & 30.67 & 87.67 & 22.45 & 0.48 & 53.51 & 10.89 & 60.23 & 74.90 & 7.94 \\
\hline $\mathrm{La}$ & 94.26 & 0.27 & 12.81 & 48.34 & 1.25 & 2.44 & 95.52 & 26.41 & 76.56 & 131.09 & 6.31 \\
\hline $\mathrm{Ce}$ & 161.21 & 0.19 & 20.27 & 77.52 & 1.39 & 8.93 & 159.46 & 77.89 & 120.67 & 231.70 & 10.95 \\
\hline $\mathrm{Sr}_{\mathrm{r}}$ & 1072.33 & 28536.95 & 25224.46 & 1195.59 & 26401.69 & 50.28 & 1211.03 & 210.03 & 1060.42 & 972.70 & 14454.72 \\
\hline $\mathrm{Nd}$ & 53.05 & 16.13 & 18.55 & 18.76 & 11.02 & 8.93 & 51.41 & 60.59 & 34.07 & 78.60 & 4.64 \\
\hline $\mathrm{Sm}$ & 7.67 & 8.03 & 5.78 & 2.54 & 4.29 & 2.71 & 7.64 & 15.16 & 5.10 & 14.93 & 0.89 \\
\hline $\mathrm{Zr}$ & 253.95 & 187.75 & 254.51 & 314.77 & 148.96 & 44.57 & 162.47 & 368.86 & 169.63 & 271.93 & 33.78 \\
\hline Hf & 4.35 & 2.09 & 3.33 & 4.72 & 1.66 & 1.46 & 3.16 & 8.45 & 2.92 & 4.90 & 0.38 \\
\hline $\mathrm{Eu}$ & 2.98 & 0.28 & 0.44 & 2.57 & 0.11 & 0.79 & 3.72 & 4.50 & 0.44 & 4.47 & 0.18 \\
\hline $\mathrm{Ti}$ & 910.95 & 71.28 & 533.74 & 1994.10 & 162.57 & 6664.85 & 1052.48 & 33175.39 & 1147.65 & 1528.91 & 96.50 \\
\hline $\mathrm{Gd}$ & 10.75 & & 1.37 & 3.81 & & 2.09 & 10.65 & 19.05 & 3.20 & 11.00 & 0.61 \\
\hline Dy & 3.94 & & 0.11 & 1.58 & & 2.25 & 4.09 & 10.10 & 2.91 & 7.14 & 0.45 \\
\hline $\mathrm{Y}$ & 17.36 & 23.65 & 27.29 & 6.41 & 21.71 & 9.29 & 16.17 & 40.20 & 15.39 & 33.88 & 2.70 \\
\hline Er & 1.86 & & 0.22 & 0.50 & 0.03 & 0.83 & 1.74 & 4.12 & 1.98 & 2,41 & 0.21 \\
\hline $\mathrm{Yb}$ & 0.75 & 0.81 & 0.59 & 0.57 & 0.54 & 0.68 & 0.71 & 2.53 & 0.91 & 1.13 & 0.14 \\
\hline $\mathrm{Li}$ & 23.47 & 0.04 & 2.16 & 3.89 & 0.44 & 0.37 & 18.15 & 2.81 & 17.91 & 6.69 & 0.23 \\
\hline $\mathrm{Be}$ & 3.53 & 0.12 & 0.46 & 3.39 & 0.31 & 0.56 & 3.46 & 0.75 & 7.03 & 5.38 & 2.31 \\
\hline $\mathrm{Sc}$ & 26.09 & 28.60 & 23.97 & 24.63 & 21.81 & 74.11 & 26.29 & 103.37 & 5.36 & 12.90 & 5.83 \\
\hline $\mathrm{Cr}$ & 2.58 & 4.51 & 12.42 & 3.38 & 5.55 & 2995.12 & 5.17 & 189.75 & 1.05 & 1.56 & 3.53 \\
\hline
\end{tabular}


APPENDIX TABLE 7:Trace element compositions of melt inclusions

\begin{tabular}{|c|c|c|c|c|c|c|c|c|c|c|c|}
\hline MAGB47 & $46 a$ & $46 \mathrm{~b}$ & $49 a$ & $50 \mathrm{a}$ & $54 a$ & $54 \mathrm{~b}$ & $55 \mathrm{a}$ & $55 \mathrm{~b}$ & $57 \mathrm{a}$ & $57 \mathrm{~b}$ & \\
\hline$\overline{\mathrm{Rb}}$ & 1.78 & 1.28 & 17.58 & 2.06 & 6.12 & 2216.25 & 4.81 & 3.82 & 5.76 & 11.07 & \\
\hline $\mathrm{Ba}$ & 1.06 & 19.02 & 720.84 & 27.87 & 30.46 & 1.39 & 63.60 & 143.51 & 232.99 & 321.83 & \\
\hline $\mathrm{Nb}$ & 8.22 & 17.61 & 37.46 & 24.00 & 30.08 & 86.13 & 22.45 & 78.65 & 52.90 & 15.79 & \\
\hline $\mathrm{La}$ & 4.59 & 7.28 & 44.88 & 7.05 & 5.77 & 0.22 & 8.46 & 28.88 & 96.80 & 179.75 & \\
\hline $\mathrm{Ce}$ & 8.82 & 15.85 & 89.50 & 14.38 & 12.34 & 3.74 & 21.25 & 64.77 & 178.98 & 264.30 & \\
\hline$S_{T}$ & 25.72 & 78.62 & 449.34 & 117.10 & 94.60 & 2.76 & 79.79 & 362.80 & 594.94 & 147.32 & \\
\hline $\mathrm{Nd}$ & 4.73 & 8.91 & 45.28 & 6.81 & 4.08 & 12.21 & 12.33 & 30.68 & 84.76 & 106.54 & \\
\hline Sm & 0.96 & 1.95 & 10.03 & 1.70 & 0.55 & 12.08 & 2.66 & 6.34 & 15.57 & 15.87 & \\
\hline $\mathrm{Zr}$ & 48.66 & 69.53 & 146.69 & 104.06 & 50.66 & 12.79 & 133.37 & 213.96 & 326.25 & 150.60 & \\
\hline $\mathrm{Hf}$ & 0.74 & 1.52 & 5.18 & 1.09 & 0.47 & 2.44 & 2.13 & 3.83 & 7.14 & 4.46 & \\
\hline $\mathrm{Eu}$ & 0.27 & 0.53 & 5.69 & 0.48 & 0.34 & 3.59 & 0.58 & 1.42 & 4.64 & 5.77 & \\
\hline $\mathrm{Ti}$ & 3086.71 & 4396.12 & 28348.80 & 5800.80 & 1554.71 & 115.25 & 7750.01 & 15780.62 & 27918.77 & 12698.95 & \\
\hline $\mathrm{Gd}$ & 0.74 & 1.29 & 14.25 & 1.54 & 0.94 & 1.05 & 2.24 & 4.15 & 21.59 & 26.83 & \\
\hline Dy & 0.57 & 1.33 & 8.16 & 1.02 & 0.44 & 3.93 & 2.04 & 4.11 & 10.24 & 9.07 & \\
\hline $\mathrm{Y}$ & 3.42 & 5.28 & 39.23 & 6.36 & 2.45 & 68.14 & 10.01 & 22.16 & 59.90 & 66.14 & \\
\hline Er & 0.22 & 0.60 & 3.13 & 0.47 & 0.23 & 2.57 & 1.04 & 2.30 & 5.02 & 4.13 & \\
\hline $\mathrm{Yb}$ & 0.18 & 0.39 & 2.58 & 0.39 & 0.15 & 0.90 & 0.74 & 1.31 & 2.57 & 1.25 & \\
\hline $\mathrm{Li}$ & 0.43 & 0.42 & 7.61 & 3.08 & 4.09 & & 3.16 & 2.75 & 5.01 & 7.86 & \\
\hline $\mathrm{Be}$ & 0.38 & 0.48 & 3.11 & 0.96 & 1.78 & 1.94 & 2.04 & 1.94 & 1.94 & 1.57 & \\
\hline $\mathrm{Sc}$ & 11.09 & 7.08 & 45.05 & 20.05 & 18.14 & 0.33 & 17.41 & 20.24 & 58.84 & 49.67 & \\
\hline $\mathrm{Cr}$ & 225.75 & 146.86 & 302.33 & 302.26 & 198.01 & 10805.22 & 190.87 & 195.49 & 333.19 & 312.73 & \\
\hline MAGB25 & $25 \mathrm{c}$ carbonate & $25 \mathrm{~d}$ & $25 \mathrm{e}$ carbonate & $25 \mathrm{f}$ & $25 \mathrm{~g} \mathrm{cpx}$ & $35 a$ & $35 b$ & $35 \mathrm{c}$ & $36 a$ & $38 \mathrm{a}$ & $39 a$ \\
\hline $\mathrm{Rb}$ & 0.84 & 8.94 & 4.20 & 1.32 & 2.37 & 14.13 & 1.54 & 4.85 & 0.98 & 41.78 & 4.89 \\
\hline $\mathrm{Ba}$ & 33.27 & 15.03 & 100.08 & 20.19 & 14.54 & 100.35 & 133.09 & 101.44 & 125.79 & 2957.32 & 163.19 \\
\hline $\mathrm{Nb}$ & 29.47 & 43.27 & 90.69 & 10.03 & 4.92 & 11.03 & 5.74 & 17.31 & 11.87 & 29.78 & 34.25 \\
\hline $\mathrm{La}$ & 29.91 & 1.02 & 60.22 & 7.39 & 9.37 & 10.45 & 0.28 & 22.33 & 3.08 & 31.45 & 79.94 \\
\hline $\mathrm{Ce}$ & 54.66 & 1.49 & 136.77 & 10.04 & 28.70 & 15.91 & 0.22 & 38.96 & 3.05 & 47.00 & 154.80 \\
\hline $\mathrm{Sr}$ & 312.80 & 402.42 & 10281.54 & 921.03 & 103.20 & 20990.34 & 18889.52 & 16023.07 & 18309.69 & 1424.06 & 15218.46 \\
\hline Nd & 19.41 & 0.54 & 57.07 & 2.43 & 24.48 & 16.98 & 1.45 & 12.15 & 0.55 & 16.43 & 73.42 \\
\hline $\mathrm{Sm}$ & 2.76 & 0.23 & 10.87 & 0.52 & 7.33 & 4.23 & 0.24 & 1.49 & 0.28 & 2.75 & 14.48 \\
\hline $\mathrm{Zr}$ & 112.01 & 151.14 & 553.76 & 41.75 & 170.90 & 70.22 & 13.42 & 87.19 & 78.30 & 159.54 & 409.52 \\
\hline $\mathrm{Hf}$ & 1.17 & 2.58 & 5.31 & 0.45 & 4.87 & 1.48 & 0.14 & 1.29 & 0.98 & 4.82 & 8.92 \\
\hline Eu & 0.68 & 0.03 & 3.16 & 0.08 & 1.99 & 0.47 & & 0.36 & & 7.74 & 3.84 \\
\hline $\mathrm{Ti}$ & 805.13 & 716.73 & 16049.68 & 244.29 & 13156.52 & 516.94 & 86.50 & 496.09 & 78.55 & 480.65 & 6947.67 \\
\hline $\mathrm{Gd}$ & 1.35 & 0.10 & 7.25 & 0.13 & 5.63 & 2.43 & & 0.70 & 0.05 & 3.87 & 16.08 \\
\hline Dy & 1.24 & 0.08 & 6.75 & 0.31 & 5.74 & 1.69 & 0.08 & 0.67 & 0.10 & 2.00 & 9.31 \\
\hline $\mathrm{Y}$ & 7.67 & 1.29 & 50.28 & 2.64 & 26.67 & 33.16 & 12.09 & 13.77 & 9.98 & 8.07 & 46.78 \\
\hline $\mathrm{Er}$ & 0.56 & 0.14 & 5.29 & 0.28 & 2.60 & 1.72 & 0.15 & 0.41 & 0.24 & & 4.57 \\
\hline $\mathrm{Yb}$ & 0.59 & 0.20 & 8.93 & 0.51 & 1.58 & 2.53 & 0.17 & 0.34 & 0.16 & 0.29 & 2.93 \\
\hline $\mathrm{Li}$ & 1.97 & 17.17 & 603.97 & 32.91 & 1.25 & 8.95 & 0.38 & 4.30 & 0.17 & 1.67 & 1.35 \\
\hline $\mathrm{Be}$ & 1.64 & 3.46 & 20.53 & 3.71 & 1.63 & 6.50 & 1.73 & 1.89 & 2.95 & 1.61 & 1.05 \\
\hline $\mathrm{Sc}$ & 0.25 & 4.97 & 15.64 & 0.83 & 47.16 & 27.15 & 5.50 & 3.24 & 1.58 & 40.56 & 20.19 \\
\hline $\mathrm{Cr}$ & 3.67 & 25.89 & 274.82 & 19.36 & 73.45 & 83.84 & 2.55 & 7.70 & 1.11 & 9.20 & 31.00 \\
\hline
\end{tabular}


APPENDIX TABLE 7:Trace element compositions of melt inclusions

\begin{tabular}{|c|c|c|c|c|c|c|c|c|c|c|c|}
\hline TAAB26 & $1 \mathrm{a}$ & $3 a$ & $4 a$ & $4 b$ & $5 a$ & $7 \mathrm{a}$ & $8 a$ & $8 \mathrm{a}$ average & $9 a$ & $16 \mathrm{a}$ & $18 \mathrm{a}$ \\
\hline $\mathrm{Ba}$ & 1077.34 & 459.73 & 934.49 & 822.41 & 892.44 & 580.37 & 948.39 & 994.62 & 419.53 & 754.26 & 941.13 \\
\hline $\mathrm{Nb}$ & 42.57 & 57.99 & 61.71 & 49.29 & 95.98 & 140.12 & 96.08 & 73.59 & 59.70 & 29.08 & 91.35 \\
\hline $\mathrm{La}$ & 51.04 & 45.51 & 49.29 & 37.20 & 23.74 & 108.26 & 57.71 & 54.69 & 47.23 & 16.74 & 52.53 \\
\hline $\mathrm{Ce}$ & 76.44 & 86.07 & 99.08 & 81.89 & 42.36 & 246.36 & 122.40 & 119.53 & 90.09 & 41.83 & 122.31 \\
\hline $\mathrm{Sr}$ & 1022.24 & 708.63 & 1086.49 & 1022.43 & 801.57 & 1521.38 & 857.63 & 912.78 & 1253.56 & 286.04 & 1465.04 \\
\hline $\mathrm{Nd}$ & 20.52 & 37.42 & 50.99 & 38.44 & 30.41 & 126.35 & 64.03 & 65.67 & 31.34 & 36.51 & 70.78 \\
\hline Sm & 2.61 & 6.59 & 9.49 & 8.34 & 14.41 & 22.21 & 13.05 & 13.51 & 6.75 & 9.50 & 17.90 \\
\hline $\mathrm{Zr}$ & 326.65 & 441.09 & 372.23 & 358.96 & 401.21 & 874.88 & 655.24 & 854.95 & 348.69 & 306.11 & 544.63 \\
\hline $\mathrm{Ti}$ & 5113.88 & 7384.32 & 22821.60 & 9390.45 & 29915.19 & 33529.36 & 17901.41 & 15497.09 & 9092.98 & 22280.12 & 33493.87 \\
\hline Dy & 1.11 & 5.37 & 5.94 & 4.62 & 7.95 & 14.53 & 9.57 & 9.14 & 2.34 & 8.34 & 10.21 \\
\hline $\mathrm{Y}$ & 10.47 & 18.57 & 25.47 & 21.41 & 12.95 & 60.07 & 37.10 & 31.46 & 13.30 & 36.17 & 45.42 \\
\hline $\mathrm{Yb}$ & 0.41 & 1.45 & 1.36 & 1.14 & 3.53 & 5.45 & 2.96 & 2.69 & 2.08 & 2.45 & 3.56 \\
\hline
\end{tabular}

\begin{tabular}{|c|ccc|}
\hline MAGB25 & $44 \mathrm{a}$ & $52 \mathrm{a}$ & $54 \mathrm{a}$ \\
\hline $\mathrm{Rb}$ & 10.13 & 19.36 & 28.32 \\
$\mathrm{Ba}$ & 138.08 & 545.71 & 341.87 \\
$\mathrm{Nb}$ & 29.36 & 59.24 & 119.55 \\
$\mathrm{La}$ & 39.33 & 57.12 & 31.37 \\
$\mathrm{Ce}$ & 69.11 & 104.97 & 84.75 \\
$\mathrm{Sr}$ & 564.40 & 1061.80 & 1010.66 \\
$\mathrm{Nd}$ & 20.61 & 41.29 & 57.17 \\
$\mathrm{Sm}$ & 2.42 & 8.79 & 13.19 \\
$\mathrm{Zr}$ & 145.90 & 163.57 & 362.69 \\
$\mathrm{Hf}$ & 2.50 & 2.41 & 7.31 \\
$\mathrm{Eu}$ & 0.97 & 1.02 & 4.75 \\
$\mathrm{Ti}$ & 371.06 & 2839.44 & 26968.74 \\
$\mathrm{Gd}$ & 0.97 & 0.84 & 19.28 \\
$\mathrm{Dy}$ & 1.13 & 5.82 & 9.73 \\
$\mathrm{Y}$ & 7.14 & 27.31 & 45.31 \\
$\mathrm{Er}$ & 0.70 & 3.10 & 4.34 \\
$\mathrm{Yb}$ & 0.60 & 1.22 & 2.81 \\
$\mathrm{Li}$ & 3.31 & 14.17 & 16.86 \\
$\mathrm{Be}$ & 3.76 & 4.75 & 2.07 \\
$\mathrm{Sc}$ & 2.80 & 6.00 & 65.08 \\
$\mathrm{Cr}$ & 22.73 & 10.63 & 273.30 \\
\hline
\end{tabular}


APPENDIX TABLE 7:Trace element compositions of melt inclusions

\begin{tabular}{|c|c|c|c|c|c|c|c|c|c|c|}
\hline TAAB26 & $20 \mathrm{a}$ & $21 \mathrm{a}$ & $22 \mathrm{a}$ & $29 \mathrm{a}$ & 29a average & $30 \mathrm{a}$ & $30 \mathrm{a}$ average & $32 a$ average & $59 a$ & $60 \mathrm{a}$ \\
\hline $\mathrm{Ba}$ & 1086.94 & 923.58 & 1369.79 & 312.35 & 285.86 & 673.33 & 636.33 & 1001.29 & 1293.78 & 1078.10 \\
\hline $\mathrm{Nb}$ & 52.36 & 102.23 & 130.93 & 115.98 & 104.80 & 50.16 & 47.40 & 61.07 & 95.91 & 64.23 \\
\hline $\mathrm{La}$ & 60.86 & 55.22 & 75.52 & 161.75 & 177.41 & 39.26 & 34.75 & 52.42 & 55.74 & 41.41 \\
\hline $\mathrm{Sr}$ & 1215.50 & 1318.70 & 1733.73 & 941.71 & 985.07 & 637.82 & 602.46 & 1404.35 & 2031.49 & 1397.17 \\
\hline $\mathrm{Nd}$ & 36.01 & 61.47 & 48.91 & 134.26 & 152.39 & 44.85 & 39.23 & 50.64 & 63.53 & 28.45 \\
\hline $\mathrm{Sm}$ & 5.27 & 12.62 & 7.49 & 26.64 & 28.81 & 9.51 & 9.06 & 9.53 & 11.47 & 4.97 \\
\hline $\mathrm{Zr}$ & 432.24 & 741.84 & 456.58 & 1065.89 & 1394.17 & 485.71 & 472.11 & 496.47 & 541.68 & 457.36 \\
\hline Dy & 4.11 & 7.58 & 4.14 & 13.69 & 15.83 & 6.57 & 6.45 & 5.86 & 8.90 & 2.97 \\
\hline $\mathrm{Y}$ & 20.33 & 31.41 & 21.60 & 69.38 & 79.78 & 30.45 & 27.22 & 26.86 & 46.94 & 17.31 \\
\hline $\mathrm{Yb}$ & 1.35 & 2.26 & 1.99 & 5.51 & 7.84 & 3.21 & 2.15 & 2.40 & 3.47 & 1.28 \\
\hline & & & & & & & & & & \\
\hline
\end{tabular}




\section{Chapter Four}

\section{U series isotopic variability in Galapagos lavas, evidence of a warm-spot}

\subsection{Abstract}

Evaluation of $\mathrm{U}$ series disequilibrium, trace element composition and $\mathrm{Sr}, \mathrm{Nd}$ and $\mathrm{Pb}$ isotopes of Galapagos lavas indicates that magma mixing between plume and asthenospheric melts has been the main process responsible for the geochemical variation observed in the archipelago. Correlation between $\mathrm{He}$ isotopes and $\mathrm{Ti} / \mathrm{Ti}^{*}, \mathrm{~K} / \mathrm{Rb}$ and $\mathrm{Nb} / \mathrm{La}$ ratios suggest that the mantle plume has positive anomalies of $\mathrm{Nb}$ and $\mathrm{Ti}$ and negative anomalies of $\mathrm{K} .{ }^{230} \mathrm{Th}$ excesses measured in the lavas indicate that the basalts from Galapagos originated total or partially in the garnet stability field. Mantle upwelling velocity for the Galapagos plume (Fernandina) ranges from $\approx 1$ to $2 \mathrm{~cm} / \mathrm{y}$ with a maximum porosity of $0.3 \%$ indicating that Galapagos is a mildly buoyant plume. Very slow mantle upwelling rates and very low porosity for Pinta $(0.5$ to $1 \mathrm{~cm} / \mathrm{y}$ and $0.1 \%$ ) and Floreana $(0.1 \mathrm{~cm} /$ year and $<0.1 \%)$ support the hypothesis that the movement of the plume across the $91^{\circ} 50^{\prime}$ transform fault produced slow upwelling and small extents of melting.

\subsection{Introduction}

$\mathrm{U}$ decay series isotopes provide information on magmatic processes and mantle source compositions that are inaccessible by any other isotopic systems. Thus, ${ }^{238} \mathrm{U}_{-}{ }^{230} \mathrm{Th}$ disequilibrium provides quantitative evaluation of the present-day depletion of the mantle source, the extent of melting represented by erupted lavas, and helps to constrain estimation on the mantle porosity and upwelling velocities during melting (Elliot, 1997 and references therein). Two end-member models have been used to explain the extent of disequilibrium in volcanic rocks:

1) as an index of elemental fractionation during melting (Sims et al., 1995),

and 
2) as an indication of ${ }^{230} \mathrm{Th}$ ingrowth during time-dependent melting and melt transport (McKenzie, 1985; Williams and Gill, 1989; Spiegelman and Elliott, 1993).

$\mathrm{U}$ series isotopes have also been useful in dating young lavas, estimating magma chamber residence times (Allègre and Condomines, 1976; Goldstein et al., 1994, Sigmarsson, 1996), and in probing the slab-component input in subduction zone volcanism (Gill and Williams, 1990; Hawkesworth, et al., 1997, Elliot et al., 1997). Moreover ${ }^{238} \mathrm{U}$ ${ }^{230} \mathrm{Th}$ disequilibrium has been used as a geodynamic indicator of the strength of the plumes traveling through the convecting mantle (Chabaux and Allègre, 1994) and as a sign of ridge-hotspot interaction (Bourdon et al., 1996). Thus, U decay series isotopes have become one of the most powerful geochemical tools to answer fundamental questions in igneous petrogenesis (Condomines et al., 1988, Goldstein et al., 1992; Rubin and Macdougall, 1992; Cohen and O'Nion, 1993; Hémond et 'al., 1994; Chabaux and Allègre, 1994; Lundstrom et al., 1995; Bourdon et al., 1996; among others).

The Galapagos archipelago has been the object of many geologic studies since Darwin's (1860) first report on the islands. Although the Galapagos islands have been interpreted as the surface manifestation of a mantle plume, geological, geophysical and geochemical studies have found it challenging to fit the Galapagos plume to a "standard" hotspot model. In contrast to Hawaii (the "archetype" of the plume model), the Galapagos islands do not form a linear chain. The volcanism is not strictly time-transgressive in the direction of the plate motion, nor is there a consistent petrological or geochemical evolution of the volcanism as seems to be the case in Hawaii. In fact, the differences between Galapagos and the standard hotspot model make this archipelago unique. For example, the historic to Holocene volcanism occurs throughout a region of $30,000 \mathrm{~km}^{2}$, and the geographical distribution of various petrological and geochemical lava types within the archipelago is quite diverse (McBirney and Williams, 1969; Geist, 1992; White et al., 1993 and references therein). These differences have been explained by entrainment of astenospheric mantle into the plume subject to velocity shear, and by interaction of the plume with the Galapagos Spreading Center (Geist et al., 1988; Richards and Griffiths, 1989; White et al., 1993; Ito et al., 1997). Thus, the Galapagos islands provide a unique natural laboratory to test petrologic, tectonic and fluid dynamic models of ridge-hotspot interaction. Although the Galapagos plume is one of the two best known examples for ridge-hotspot interaction, data for $\mathrm{U}$ series isotopes in Galapagos lavas do not exist. 
We present here the first data for ${ }^{238} \mathrm{U}^{-230} \mathrm{Th}-{ }^{232} \mathrm{Th}$ isotopes on a suite of 29 basalt samples from the Galapagos islands. The samples are geochemically well-characterized and of known age, and were chosen to represent the different petrographic and geochemical groups observed in the Galapagos archipelago (McBirney and Williams, 1969; Geist, 1992; White et al., 1993, Kurz and Geist, 1999). The main objective of this work is to constrain the mantle composition, extent of melting, mantle upwelling velocity and porosity beneath the Galapagos islands. We compare our $U$ decay series results with those obtained from three dimensional numerical model of the interaction between mantle plumes and migrating mid-ocean ridges (Ito et al., 1997). The diffuse nature of the Galapagos plume suggests it is significantly less intense thermally than the Hawaiian hotspot .

\subsection{Geodynamic Background}

The Galapagos archipelago is located in the eastern equatorial Pacific, $1000 \mathrm{~km}$ west of South America, and approximately $150 \mathrm{~km}$ south of the active Galapagos Spreading Center (GSC) (Figure 1). The islands and numerous seamounts are constructed mainly upon a shallow submarine volcanic platform overlying a very young lithosphere (< $10 \mathrm{Ma})$. The GSC is a moderately fast spreading ridge $(\approx 6 \mathrm{~cm} /$ year $)$; judging from the volcanic traces of the hotspot (the Cocos and the Carnegie Ridges), the ridge has migrated northward away from the Galapagos hotspot in the last 5 to $6 \mathrm{Ma}$ (Hey, 1977). The transform fault at $90^{\circ} 50^{\prime}$ offsets the GSC by $150 \mathrm{~km}$ and is the boundary between symmetric spreading to the west and asymmetric spreading to the east. This fracture zone divides the Galapagos platform into two main sectors (the western and eastern sectors) with an estimated 5 Ma age discontinuity across the lithospheric sectors (Hey, 1977). Analysis of bathymetric and gravity data indicates that the eastern sector of the archipelago is underlain by a weak, younger lithosphere with an elastic thickness of $6 \mathrm{~km}$ or less and close to Airy compensation. In contrast, the western sector is flexurally supported by a lithosphere with an elastic thickness of $12 \mathrm{~km}$ (Feighner and Richards, 1994). It is important to remark that the transition from the eastern to the western sector is sharp and can be modelled as a fault zone (Figure 1). The crustal thickness increases from approximately $10 \mathrm{~km}$ on the margin of the Galapagos platform to as much as $18 \mathrm{~km}$ beneath southeastern Isabela.

Galapagos volcanoes are aligned in two rough trends N30W and N60E (Darwin, 1860). Prominent block faulting can also be seen in the central and southern islands 
(McBirney and Williams, 1969). Altogether, the evidence suggests that faulting either controls or greatly modifies the major structural features of the Galapagos hotspot region (Feighner and Richards, 1994). There is not yet a good explanation for these alignments, as they bear no simple relationship to plate motion, local transform directions or likely direction of plume flow (Geist and Reynolds 1998).

The first geologic report on the Galapagos was made by Darwin (1860); since then, many reports and studies have followed. The first detailed geologic and petrologic study of the archipelago as a whole was done by McBirney and Williams, (1969); this was followed by the work of Geist et al, (1988); Geist, (1992); and White et al, (1993). Many studies have contributed in considerable detail to our understanding of individual volcanoes and islands (see Geist, 1992; White et al, 1993; and reference therein). We present here a brief synthesis of these works. To the west of the $90^{\circ} 50^{\prime}$ transform fault, the eruptive edifices are large central shield volcanoes of unusual shape ('inverted soup-bowl") with welldeveloped calderas, and with lavas erupting from radial and ring fissures. These volcanoes have the most frequent historic volcanic and seismic activity due to their location close to the present position to the plume at Fernandina, (Kurz and Geist, 1999). In contrast, the volcanoes to the east of the fracture zone are seismically quiet and they present more varied morphologies and eruptive histories. This difference in size of the volcanic edifices probably reflects the effect of lithospheric thickness, with older and thicker lithosphere being able to support larger volcanic structures.

From the 21 emergent volcanoes in the Galapagos, 9 have been active historically and four others have been active in the Holocene. There is no clear age progression in the geographic distribution of the volcanoes. However, the ages of the oldest lava dated in each volcano form a progression from young in the west to old in the east (White et al., 1993; Kurz and Geist, 1999). The islands, as they drift away from the hotspot, have had intermittent eruptions for at least 2.4 Ma, as in the case of San Cristobal island (White et al., 1993; Kurz and Geist, 1999). The continuous volcanism in this most easterly island indicates either an extended zone of melting downstream from the plume or the existence of postshield extensional volcanism across the Galapagos platform.

Geochemically, Galapagos lavas have lower $\mathrm{SiO}_{2}$ and higher $\mathrm{FeO}, \mathrm{Na}_{2} \mathrm{O}, \mathrm{CaO}$, $\mathrm{K}_{2} \mathrm{O}$ and $\mathrm{TiO}_{2}$ than MORB (at the same $\mathrm{MgO}$ content). Lavas erupted from the large western. volcanoes are in general moderately fractionated tholeiites, while lavas erupted 
from small cones and vents from the eastern islands are compositionally diverse, ranging from picrites to basanitoids. Most of the isotopic variation observed in the Galapagos archipelago occurs between islands or even between volcanoes in the same island, as in the case of Isabela island. However, lavas erupted in some of the eastern islands (San Cristobal, Santa Cruz Santiago) show significant intra-island variation in isotopes, largely related to geographic or temporal sequences. Major and trace element contents and ratios have been used to suggest that melting appears to be less extensive and shallower to the east and south, a possible indication of a cooler mantle away from the center of the plume (White et al., 1993; Geist, 1992; Geist et al, 1988). However, it has been extremely difficult to unequivocally separate effects due to the extent and depth of melting from those of source composition. For example, Geist (1992) proposed that the depth of melt segregation can be estimated in Galapagos lavas from an inverse correlation between $\mathrm{Si}_{8}$ and $\mathrm{Fe}_{8}$. Although $\mathrm{Fe}_{8}$ and $\mathrm{Na}_{8}$ are frequently used as indicators of pressure and extents of melting respectively (Geist et al., 1988; White et al., 1993), in Galapagos these indices correlate with He isotopes, which is an indicator of source composition (Kurz and Geist, 1999). White et al. (1993) estimated the degree and depth of melting by considering ratios of LREE to MREE and MREE to HREE, for samples of similar Nd isotopes composition. Thus, White et al. concluded that lavas from the eastern islands, especially Floreana and San Cristobal, were probably produced by a low extent of melting in the spinel stability field (shallow depths). However, these same authors also show that in Galapagos lavas $(\mathrm{La} / \mathrm{Sm})_{\mathrm{PM}, 8}$ ratios $(\mathrm{La} / \mathrm{Sm}$ ratios normalized to primitive mantle and at $\mathrm{MgO}$ content $\approx 8$, averaged by volcano) correlate with averaged isotopic compositions, suggesting a source control on the REE.

Isotopes and incompatible element ratios from Galapagos lavas define a "horse shoe"-like geographic pattern, with the most depleted signatures (MORB) appearing in the center of the archipelago and the most enriched signatures emerging on the eastern, northern and southern peripheries (Geist et al. 1988; White et al., 1993). This horse shoe pattern has been explained by entrainment of astenospheric mantle into the plume, controlled by velocity shear produced by the moving lithosphere (Richards and Griffiths, 1989).

The GSC basalts at $92^{\circ} \mathrm{W}$ have anomalously enriched $\mathrm{Sr}$ isotopic compositions, clear evidence of the interaction between the ridge and the Galapagos plume (Schilling et al., 1982; Verma and Schilling, 1982). Surprisingly, the geochemical anomaly does not 
occur at the closest position of the GSC to the Galapagos archipelago, but further to the northwest, at the intersection of the Darwin-Wolf lineament and the GSC. Morgan (1978) suggested that the plume flow was channeled at shallow level beneath the Darwin-Wolf lineament. However, basalts dredged from this lineament become isotopically more plumelike toward the GSC (Harpp et al. , 1990). This observation requires plume flow in the opposite direction to that in which the shallow asthenosphere is being dragged by the moving plate. Therefore, the flow from the plume toward the ridge must be deep rather than shallow, perhaps related to deep asthenospheric counterflow toward the ridge (White et al., 1993).

\subsection{Sampling and Analytical techniques}

We sampled historic to Holocene lavas from numerous volcanoes and islands from the Galapagos archipelago. Our strategy was to obtain representative samples from the different lava types that define the geographical "horse shoe" pattern in isotopes and incompatible element ratios observed in the Galapagos (Geist et al., 1988; Geist, 1992; White et al., 1993). The sampling was simplified by the fact that the observed isotopic variation in the Galapagos archipelago occurs between islands or even between volcanoes in the same island; the intra-volcanic variations are generally small. We selected samples from the large central shield volcanoes from the western area and from volcanoes representing more varied morphologies and eruptive histories in the eastern sector of the archipelago. At the same time, this strategy took into account basalts erupted through lithosphere of different ages and elastic thickness by sampling east and west of the fracture zone defined by Feighner and Richards (1994). We selected 29 samples for U-series analysis:

a) samples from Fernandina Vn. (8), Cerro Azul Vn. (4), Wolf Vn. (4), Sierra Negra (3), Darwin Vn. (2) and Ecuador (1) represent the large shield volcanoes, closest to the center of the plume, erupted on the older and thicker lithosphere to the west of the $90^{\circ} 50^{\prime}$ fracture zone.

b) basalts from San Cristobal (3), Santiago (1), Floreana (1), Pinta (1) and Marchena (1) represent small volcanoes erupted away from the center of the plume on a thin and young lithosphere, east of the fracture zone. 
When possible several samples with similar $\mathrm{Sr}, \mathrm{Nd}, \mathrm{Pb}$ and $\mathrm{He}$ (i.e. constant source composition) isotopic composition were taken from a single volcano to evaluate the melting process. However, we faced the problem that lavas from isotopically homogeneous volcanoes (western volcanoes) generally are less primitive (e.g. low $\mathrm{MgO}$ contents), and are typically homogeneous in trace element ratios (i.e., Fernandina lavas). Therefore, the limited variation in trace element ratios does not allow us to make a precise evaluation of melting processes. In the eastern islands, where the trace element variations are larger, either the lavas are variable in isotopic composition, or they are too old for $U$ decay series analysis (i.e., Floreana lavas). Moreover, lavas from the northern islands, like Marchena, are very poor in olivine phenocrysts (the mineral used for surface exposure dating techniques), making it impossible to obtain ages for those basalts. This is the main reason that the number of analyses in the eastern and northern islands are fewer than in the western volcanoes.

The selection of samples for $U$ decay series analysis was constrained mainly by the age data available for the lavas. Many of the samples are from well recorded historic eruptions, such as in Fernandina and Marchena. All our samples have been dated by surface exposure dating, with the exception of those samples obtained from well recorded historic eruptions. This technique, using cosmogenic ${ }^{3} \mathrm{He}$ (Kurz, 1986; Kurz et al., 1990, Kurz and Geist, 1999), has been ideal for the Galapagos archipelago where other dating techniques have failed. The ${ }^{14} \mathrm{C}$ dating technique is difficult to apply because the arid climate in the Galapagos makes charcoal virtually nonexistent. Also, ${ }^{40} \mathrm{~K}-{ }^{40} \mathrm{Ar}$ and ${ }^{39} \mathrm{Ar}-$ ${ }^{40} \mathrm{Ar}$ techniques have been difficult to apply to lavas younger than 100,000 years, mainly due to the low potassium content of most Galapagos lavas.

Most of the samples for surface exposure dating were collected from the top 5 to 10 $\mathrm{cm}$ of lava flows to minimize the correction for depth in the lava flows. Wherever possible, we sampled pahoehoe lavas or large blocks from aa flows where original orientation was preserved (Kurz and Geist, 1999). The preservation of the lava flow surface is extremely good in the Galapagos due to the slow rate of weathering in the arid climate. A serious limitation to the surface exposure dating was the scarcity of olivine phenocrysts, the ideal mineral phase for surface exposure dating (Kurz and Geist, 1999). For example, the lack of olivines was a serious limitation in lavas from the western and northern Galapagos volcanoes (Sierra Negra, Alcedo, Wolf, Fernandina, Marchena, among the most important). The ages were calculated using sea level and high latitude production rate scaled 
to equatorial areas (Lal, 1991). The uncertainties reported only consider the analytical uncertainty and not the errors in the absolute production rate (Kurz and Geist, 1999). For more detail on the analytical techniques please refer to Kurz (1986) and Kurz et al. (1996).

The analytical technique and uncertainties for $\mathrm{Sr}, \mathrm{Nd}, \mathrm{Pb}$ and $\mathrm{He}$ isotopes are reported in Kurz et al., (1995; 1996) and Kurz and Geist, (1999). Major and trace element data reported here were done by XRF and ICP-MS at Washington State University. The precision for XRF data (major and trace elements) for seven repeat analyses of BCR-P was $<1 \%(2 \sigma)$ for all major elements, except $\mathrm{MnO}, \mathrm{K}_{2} \mathrm{O}, \mathrm{Na}_{2} \mathrm{O}$ and $\mathrm{P}_{2} \mathrm{O}_{5}$ with $<3 \%(2 \sigma)$. The precision for XRF analyses for trace elements was $<5 \%(2 \sigma)$ for most elements, $<10 \%$ $(2 \sigma)$ for $\mathrm{Rb}, \mathrm{Ga}, \mathrm{Cu}$ and $\mathrm{Zn},<20 \%(2 \sigma)$ for $\mathrm{Sc}$, and $<30 \%(2 \sigma)$ for $\mathrm{Ba}$. The precision for ICP-MS data on a single sample BCR-P run over a four month period $(\mathrm{n}=24)$ was $<5 \%$ $(2 \sigma)$ for most trace elements, $<10 \%(2 \sigma)$ for $\mathrm{Cs}, \mathrm{Rb}, \mathrm{Pb}$ and $<20 \%(2 \sigma)$ for $\mathrm{Th}$ and $\mathrm{U}$.

To determine U-Th concentrations and Th isotope ratios the fresh interiors of the samples were crushed $(\approx 1 \mathrm{~kg})$ in a steel jaw crusher. The coarse fraction (between 1 to 2 $\mathrm{cm}$ ), was cleaned in an ultrasonic bath with ultrapure water. The chips were dried at low temperature on a hot plate, and inspected under the binocular microscope to avoid any altered material. To avoid problems of sample inhomogeneity, we selected approximately 30 to $50 \mathrm{~g}$ of material to be powdered. The chips were powdered in an agate shatter box for no longer than a couple of minutes to minimize contamination. 1 to 2 grams of sample were dissolved and aliquots from the solution were used to chemically separate $U$ and Th by standard chromatographic techniques (similar to the procedure reported in Goldstein et al., 1989a and b). For Th isotope determinations, a grade A spectrographycally pure carbon planchette, pre-cleaned with isopropanol in an ultrasonic bath, is heated on a hot plate between 80 and $100^{\circ} \mathrm{C}$. A low temperature polyethylene tube $900 \mu$ in inside diameter is positioned perpendicular to the planchette such that when the tube touches the hot planchette a ring of melted plastic $750 \mu$ in diameter is formed on the carbon. The unspiked Th concentrated from the chromatographic column is dissolved in $1 \mu 1$ of $0.3 \mathrm{~N}$ HNO3 and loaded onto the planchette at $80^{\circ} \mathrm{C}$, inside the plastic ring. The ring is used as a dam to avoid spreading of the Th solution as it dries down into the planchette (spreading of the Th load produces a decrease in Th concentration per unit area, resulting in low intensity measurements). The solution is dried down into the carbon generating a conductive matrix that allows the Th to be analyzed by ion probe. The plastic ring was monitored to be absolutely sure it did not contribute any contaminant or artifact to the measurements. 
The Th isotopic ratios were determined on the IMS Cameca 1270 ion microprobe at the Woods Hole Oceanographic Institution (Layne and Sims, 1999). We used a nominal primary accelerating voltage of $12.5 \mathrm{keV}$ with $\mathrm{a}^{16} \mathrm{O}^{-}$beam, a secondary accelerating voltage of $10 \mathrm{keV}$, and currents ranging from 90 to $225 \mathrm{nAmps}$ in a $250 \mu$ square raster. The dynamic transfer optics were utilized to recover $100 \%$ of the rastered beam. To resolve isobaric interferences, secondary ions were analyzed at a mass resolution of 2000 , with no energy filtering. Each analysis comprised 150 cycles of alternating measurements of ${ }^{232} \mathrm{Th}$ in the Faraday cup ( $2 \mathrm{~s}$ counting), ${ }^{230} \mathrm{Th}$ in the electron multiplier (6 $\mathrm{s}$ counting), background in the electron multiplier ( $2 \mathrm{~s}$ counting) and background in the Faraday cup ( $2 \mathrm{~s}$ counting). Calibration for the gains of the detectors were done by measuring ${ }^{232} \mathrm{Th}$ in a pure metal in both the Faraday cup and the electron multiplier. We used a gravimetric standard solution from the University of California Santa Cruz (generously supplied by J. Gill and C. Lundstrom), previously analyzed by TIMS as a standard during the period of our Th isotopes measurement. Layne and Sims (1999) measured the Th metal and the standard one after the other in sequence to correct for gain calibrationand and to evaluate reproducibility. The ion probe analyses for the standard ${ }^{232} \mathrm{Th} /{ }^{230} \mathrm{Th}=1.71 \times 10^{5} \pm 0.7 \%$ $(n=20)$, reproduced within errors the TIMS value of $1.706 \times 10^{5} \pm 0.8 \%(2 \sigma, n=30)$ (Figure $2 \sigma)$. The standard was measured two to three times a day, interpersed with our runs. The total Th content of the loaded standard was similar to that of the samples. During the course of our runs only ones we determine the gain calibration by measuring ${ }^{232} \mathrm{Th}$ in a pure metal with the Faraday cup and electron multiplier. To correct for mass fractionation and detector gain variation in our samples, we normalized the ${ }^{232} \mathrm{Th} /{ }^{230} \mathrm{Th}$ values obtained for the standards measured each day to a standard value for ${ }^{232} \mathrm{Th} /{ }^{230} \mathrm{Th}=1.71 \times 10^{5}(\mathrm{n}=20)$. The rational behind directly normalizing the measured values for the standard to a ${ }^{232} \mathrm{Th} /{ }^{230} \mathrm{Th}=1.71 \times 10^{5}$ is the constancy of the obtained value for gain calibration using $\mathrm{Th}$ metal during several days (Layne and Sims, 1999; G. Layne pers. com., 1999). Typical ${ }^{230} \mathrm{Th}$ and ${ }^{232} \mathrm{Th}$ count rates for our samples were approximately $>200 \mathrm{cps}$ for ${ }^{230} \mathrm{Th}$ and $>$ $10^{7} \mathrm{cps}{ }^{232} \mathrm{Th}$. The typical in-run precision for the Th isotopic measurements in the Galapagos samples ranges from $\approx 0.5 \%(2 \sigma)$ to $1 \%(2 \sigma)$ similar to or slightly better than the external reproducibility.The agreement for a duplicate analysis of sample NSK97-224 is $\approx 1.0 \%$.

Th and $U$ concentrations were determined by isotopic dilution using a Finnigan MAT Element ICP-MS at the Woods Hole Oceanographic Institution. A small aliquot (3 - 
$5 \%$ ) from the initial solution is spiked with ${ }^{229} \mathrm{Th}$ and ${ }^{233} \mathrm{U}$ spikes such that the ${ }^{232} \mathrm{Th} /{ }^{229} \mathrm{Th}$ and ${ }^{238} \mathrm{U} /{ }^{233} \mathrm{U}$ ratios are approximately 30 and 10 respectively. Special care was taken to insure sample/spike equilibration, by drying down the solution several times with $\mathrm{HClO}_{4}$. The $T h$ and $U$ are separated by standard chromatographic methods and the Th- $U$ concentrate is diluted in $5 \mathrm{ml}$ of 1-2 N HNO3 solution. The ICP-MS is tuned and calibrated twice a day with a $0.5 \mathrm{ppm}$ solution of 16 different elements (from $\mathrm{Li}$ to $\mathrm{U}$ ). Each sample analysis comprised 2000 cycles of alternating measurements of ${ }^{232} \mathrm{Th},{ }^{229} \mathrm{Th},{ }^{238} \mathrm{U}$ and ${ }^{233} \mathrm{U}$. The typical in-run precision for the ${ }^{232} \mathrm{Th} /{ }^{229} \mathrm{Th}$ and ${ }^{238} \mathrm{U} /{ }^{233} \mathrm{U}$ measurements are $<0.3 \%(2 \sigma)$. The concentrations of ${ }^{229} \mathrm{Th}$ and ${ }^{233} \mathrm{U}$ in our spikes are known to approximately $0.5 \%(2 \sigma)$. To avoid memory effect, washout time of 15 to 20 minutes were used between samples. To monitor the memory effect, we ran blanks of 1-2 $\mathrm{N} \mathrm{HNO}_{3}$ solution between every four samples.

We used the U standard NBS 960 to correct for U mass fractionation, and assumed the same fractionation per amu for Th. The observed mass fractionation in the standard was $\approx 0.2 \%$ per amu. Each sample was bracketed between runs of the standard, and corrected individually based on the mean mass fractionation value of the two standard. To evaluate external reproducibility of NBS $960 \mathrm{U}$ standard, we corrected the standard for fractionation in the same way as we did for the samples. Namely, Standard \#1 and \#3 were used to correct standard \#2 for fractionation; standard \#2 and \#4 were used for standard \#3, etc. Results are shown in Figure $2 \mathrm{~b}$. The external reproducibility of the NBS960 U standard was $\approx 0.2 \%(2 \sigma, \mathrm{n}=23)$. Two total procedure blanks gave values of 50 and $160 \mathrm{pg}$ for Th and $U$ respectively. All samples have been corrected for blank contribution.

\subsection{Results}

\subsubsection{Major elements, trace elements and $\mathrm{Sr}, \mathrm{Nd}, \mathrm{Pb}$ and $\mathrm{He}$ isotopes}

Most of the major, trace element and isotope data used in this work have been already published. The dataset used here is mainly from Kurz and Geist, (1999), complemented with data from Geist and coworkers (Geist, 1992 and reference therein), and from White et al. (1993); we have included some unpublished data from Kurz and Geist (personal communication). Table 1 lists representative major, trace element, and isotope analyses from the published and unpublished data set of Kurz for those samples analyzed for $U$ series isotopes. 
All of the lavas are basalts, mostly tholeiitic with only a few alkali basalts (Figure 3a). Mg\# ranges from 0.56 to 0.26 indicating that all the samples have undergone fractional crystallization, mainly at low pressure (Geist, 1992; White et al., 1993) (Figure 3b). In some cases, like Cerro Azul, Nauman and Geist, (1998) have suggested that the range in major element contents in contemporaneous lavas (from tholeiites to alkali basalt), is the result of high pressure fractional crystallization.

Figure 4 shows primitive-mantle-normalized trace element diagrams for representative samples analyzed for $U$ decay series. There are important variations in trace element patterns between lavas erupted in the western volcanoes (e.g., Fernandina and Darwin) and those from the eastern islands (e.g., San Cristobal and Floreana). Lavas from the western volcanoes have higher MREE/HREE ratios and less intra-volcano variability than lavas from the eastern islands; features already observed by White et al., (1993). These authors suggested that the variation in MREE/HREE ratios between lavas from the western volcanoes and those from the eastern islands was produced by difference in the depth of melting, from the garnet to the spinel stability field respectively. However, the lower MREE/HREE ratios in basalts from the eastern area are mainly produced by the variations in MREE rather than the variations in the HREE (Figure 5a). For example, Floreana lavas have similar LREE/HREE ratios and higher LILE, but lower MREE contents than those measured in basalts from the western volcanoes (Figure $5 \mathrm{a}$ and $\mathrm{b}$ ). This is an unexpected result assuming the variation in trace element content is produced by difference in the extent of melting or depth of melt segregation. Moreover, lavas from Darwin and Wolf volcanoes have relatively low LREE/HREE but high MREE/HREE ratios compared to other lavas from the western volcanoes (Figure $5 b$ ).

Lavas from the western volcanoes are characterized by positive anomalies of $\mathrm{Nb}$, $\mathrm{Ta}$ and $\mathrm{Ti}$ and negative anomalies of $\mathrm{K}$ and $\mathrm{Y}$. These anomalies tend to decrease or disappear in lavas with flat trace element pattern (low $\mathrm{Hf} / \mathrm{Lu}$ ) from the eastern islands, with the exception of a $\mathrm{Ti}$ anomaly in the Floreana basalts (Figure 4a and 6). Positive $\mathrm{Sr}$ anomalies seems to be ubiquitous in the Galapagos archipelago. The $\mathrm{Sr}$ anomaly tends to be small in the western volcanoes, probably due to plagioclase fractionation, and large in basalt from the eastern islands (Figure 4a). Lavas from Floreana and San Cristobal islands have low Th and $U$ contents relative to elements of similar compatibility, features that are not observed in basalts from the western volcanoes (Figure 4a). 
The Marchena and Pinta samples have not been analyzed for trace or major elements. White et al, (1993) reported REE data for samples from both islands. The REE content in Marchena samples defines a flat slightly concave downward pattern. In contrast, Pinta samples have enriched LREE similar to the lavas from the southern Isabela volcanoes.

$\mathrm{Sr}, \mathrm{Nd}, \mathrm{Pb}$ and $\mathrm{He}$ data have been discussed extensively in Geist et al. (1988); White et al. (1993) and Kurz and Geist (1999). The data set utilized here confirms the same remarks previously made in those papers. Namely, the western volcanoes tend to be homogeneous isotopically and with higher $\mathrm{Sr}, \mathrm{Pb}$ and $\mathrm{He}$ and lower $\mathrm{Nd}$ isotopic composition than MORB. The exceptions are lavas from Darwin and Wolf volcanoes, which have MORB-like isotopic signature. In contrast, the eastern islands show a relatively large isotopic heterogeneity frequently with MORB isotopic signatures. Most of the isotopic variation in the archipelago occurs between volcanoes, and this generates a geographic distribution of the isotopic variations, which define a horse shoe pattern. A good correlation exists between $\mathrm{Sr}, \mathrm{Nd}$ and $\mathrm{Pb}$ isotopes, but the correlation of these with He isotopes is not significant with the exception of Nd isotopes (Kurz and Geist, 1999). Also, these correlations hold when average isotopic compositions of volcano are compared (White et al, 1993). Four main components are needed to bracket the isotopic composition of the Archipelago: a a MORB component defined by the Galapagos Spreading Center and Genovesa island, two components more enriched isotopically than MORB defined by Floreana and Pinta and the high He component characterized by Fernandina (White et al., 1993, Graham et al., 1993; Kurz and Geist, 1999). As is the case in all OIBs with high ${ }^{3} \mathrm{He} /{ }^{4} \mathrm{He}$ ratios (Hawaii, Iceland, Samoa), the component with the highest ${ }^{3} \mathrm{He} /{ }^{4} \mathrm{He}$ ratios (Fernandina), is associated with intermediate $\mathrm{Sr}, \mathrm{Nd}$ and $\mathrm{Pb}$ isotopic ratios (Kurz and Geist, 1999).

The relationship between incompatible trace element ratios and isotopes is interesting. White et al, 1993, and Geist, 1992 showed that $(\mathrm{La} / \mathrm{Sm})_{\mathrm{PM}, 8}$ (normalized to primitive mantle and to $\mathrm{MgO}=8$ ), averaged by volcano, correlates with averaged $\mathrm{Sr}, \mathrm{Nd}$ and $\mathrm{Pb}$ isotopic composition. Kurz and Geist (1999) found that $\mathrm{Nb} / \mathrm{La}$ ratios correlate positively with ${ }^{3} \mathrm{He} /{ }^{4} \mathrm{He}$ isotope ratios and negatively with $\mathrm{Nd}$ isotope ratios. Fitton et al. (1998) suggested that the enrichment of $\mathrm{Nb}$ in Galapagos lavas correlates with $\mathrm{Sr}, \mathrm{Nd}, \mathrm{Pb}$ and $\mathrm{Hf}$ isotope ratios, indicating mixing between plume and MORB components. Complementing these previous observations, we also found that $\mathrm{He}$ isotopes ratios 
correlate with $\mathrm{Ti} / \mathrm{Ti}^{*}$ ( $\mathrm{Ti}$ anomaly), $\mathrm{Ti} / \mathrm{Zr}$ and $\mathrm{K} / \mathrm{Rb}$ ratios (Figure 7). Moreover, $\mathrm{Nb} / \mathrm{Zr}$, $\mathrm{Ba} / \mathrm{La}, \mathrm{K} / \mathrm{Rb}$ and $\mathrm{Ba} / \mathrm{Ce}$ ratios correlate with $\mathrm{Sr}, \mathrm{Nd}$ and $\mathrm{Pb}$ isotope ratios (Figure 8), and $\mathrm{Ti} / \mathrm{Ti}^{*}$ defines a rough correlation with $\mathrm{Nd}$ isotope ratios. The exceptions to these correlations are the alkali basalts from Floreana, which seem to be enriched in LILE contents at similar LREE contents relative to other Galapagos samples. Moreover, the Floreana lavas are depleted in Th and $U$, and enriched in Ba compared to elements with similar incompatibility (Figure 4a).

\subsubsection{U decay series}

$\mathrm{U}$, Th concentrations and $\left({ }^{230} \mathrm{Th} /{ }^{232} \mathrm{Th}\right),\left({ }^{238} \mathrm{U} /{ }^{232} \mathrm{Th}\right)$ and $\left({ }^{230} \mathrm{Th} /{ }^{238} \mathrm{U}\right)$ ratios for Galapagos samples are reported in Table 2. The $\left({ }^{230} \mathrm{Th} /{ }^{232} \mathrm{Th}\right)$ and $\left({ }^{230} \mathrm{Th} /{ }^{238} \mathrm{U}\right)$ activity ratios have been corrected by eruption ages determined by surface exposure dating techniques (Kurz, 1986; Kurz et al., 1990, Kurz and Geist, 1999). Most of the samples have eruption ages well below 10,000 years. The exceptions are three samples from San Cristobal, with ages of $9200,13,000$ and 15,000, $( \pm 1000)$ years, and one sample from Floreana with an age of $26,000 \pm 7000$ years. The $\left({ }^{230} \mathrm{Th}{ }^{238} \mathrm{U}\right)$ disequilibrium of $80 \%$ in the case of the Floreana sample is extreme. To evaluate the possibility of alteration effects, we used trace element ratios such as $\mathrm{Rb} / \mathrm{Cs}$ and $\mathrm{Ba} / \mathrm{Rb}$ which are easily modified by secondary process. The Floreana sample has $\mathrm{Ba} / \mathrm{Rb} \approx 14$ and $\mathrm{Rb} / \mathrm{Cs} \approx 89$, indistinguishable from the canonical mantle values of $13 \pm 1$ and $90 \pm 10$ respectively (Hart and Reid, 1991; Hofmann and White, 1983). This indicates that alteration is not the explanation for the large $\left.{ }^{230} \mathrm{Th} /{ }^{238} \mathrm{U}\right)$ disequilibrium in the Floreana sample.

Extended magma chamber residence times will produce a decrease in the extent of disequilibrium, leading to a smaller inferred $\mathrm{U} / \mathrm{Th}$ fractionation during the melting process. This is a concern for the western shield volcanoes that, in general, have erupted evolved and homogeneous lavas, indicating some processing in magma chambers. However, lavas from the western volcanoes with variable $\mathrm{Mg \#}$ and similar $\mathrm{Sr}, \mathrm{Nd}$ and $\mathrm{Pb}$ isotopic compositions have similar $\left({ }^{230} \mathrm{Th} /{ }^{232} \mathrm{Th}\right)$ and $\left({ }^{230} \mathrm{Th} /{ }^{238} \mathrm{U}\right)$ ratios (Figure 9). For example, the Cerro Azul lavas range from $\mathrm{Mg} \# 0.52$ to 0.28 , but have almost constant $\left({ }^{230} \mathrm{Th} /{ }^{232} \mathrm{Th}\right)$ $\approx 1.04$. Moreover, Fernandina, Cerro Azul and Ecuador, who share very similar Sr, Nd and $\mathrm{Pb}$ isotopic ratios (White et al., 1993; Kurz and Geist, 1999) show a large variation in Mg\# but are similar in Th isotopes, suggesting no significant effects due to magma chamber residence time. Therefore, although this process could have produced slight 
variation in the Th isotopes, for example in some of the lavas from Fernandina (Figure 9), the effect of magma chamber residence time on Th isotopes appears to be insignificant.

$\left({ }^{230} \mathrm{Th} /{ }^{232} \mathrm{Th}\right)$ versus $\left({ }^{238} \mathrm{U} /{ }^{232} \mathrm{Th}\right)$ activity ratios for Galapagos lavas are displayed in Figure 10a. The two most important observations are:

a) The measured $\left({ }^{230} \mathrm{Th} /{ }^{238} \mathrm{U}\right)$ ratios in the samples is much larger than 1 , indicating significant disequilibrium with ${ }^{230} \mathrm{Th}$ enriched relative to ${ }^{238} \mathrm{U}$. The extent of $\left({ }^{230} \mathrm{Th} /{ }^{238} \mathrm{U}\right)$ disequilibrium observed in the whole suite of Galapagos samples is surprising: from $\approx 20$ up to $\approx 80 \%$. Compared to a compilation of other OIBs (Lundstrom, personal communication), Galapagos samples extend to extreme disequilibrium, especially when compared to Hawaii (Figure 10b).

b) $\left({ }^{230} \mathrm{Th} /{ }^{232} \mathrm{Th}\right)$ ratios correlate positively with $\left({ }^{238} \mathrm{U} /{ }^{232} \mathrm{Th}\right)$. Most of the age corrected samples, except those from Floreana and San Cristobal, plot on a quasi linear trend extending toward higher $\left({ }^{230} \mathrm{Th} /{ }^{232} \mathrm{Th}\right)$ and higher $\left({ }^{238} \mathrm{U} /{ }^{232} \mathrm{Th}\right)$, and overlapping with the field for analyzed MORBs (Figure 10). Moreover, samples analyzed from the GSC (Williams and Gill, 1989) and the EPR at $9^{\circ} \mathrm{N}$ (Goldstein et al., 1993; Volpe and Goldstein, 1993) appear to plot on an extension of the Galapagos trend. Floreana and San Cristobal lavas plot slightly above the linear array, showing a less well defined trend toward the GSC data. Sierra Negra and Cerro Azul samples show a variation of up to $12 \%$ in $\left({ }^{238} \mathrm{U} /{ }^{232} \mathrm{Th}\right)$ at almost constant $\left({ }^{230} \mathrm{Th} /{ }^{232} \mathrm{Th}\right)$ for each suite. This variation in $\left({ }^{238} \mathrm{U} /{ }^{232} \mathrm{Th}\right)$ produces a weak cross-deviation from the linear trend defined by the rest of the Galapagos samples.

$\left({ }^{230} \mathrm{Th} /{ }^{232} \mathrm{Th}\right.$ ) correlates with $\mathrm{Nd}$ isotope ratios (Figure 11a) and $\mathrm{Sr}$ isotope ratios (not shown). Although few analyses exist for both $\mathrm{Pb}$ and $\mathrm{Th}$ isotopes in the same samples, the isotope ratios average by volcano also show a good correlation between Th and $\mathrm{Sr}, \mathrm{Nd}$ and $\mathrm{Pb}$. In contrast, ${ }^{3} \mathrm{He} /{ }^{4} \mathrm{He}$ ratios do not correlate with $\left({ }^{230} \mathrm{Th} /{ }^{232} \mathrm{Th}\right)$.

Th isotope ratios correlate with trace element ratios such as $\mathrm{Nb} / \mathrm{Zr}, \mathrm{K} / \mathrm{Nb}, \mathrm{K} / \mathrm{Rb}$, and $\mathrm{Sr} / \mathrm{Sr}^{*}$ (for lavas that did not fractionate plagioclase, $\mathrm{Sr} / \mathrm{Sr}^{*}>1$ ) (Figure 11b). In general $\left({ }^{230} \mathrm{Th} /{ }^{238} \mathrm{U}\right)$ ratios do not correlate with either trace element contents, ratios, or any indicator of extent of melting, with the exception of $\mathrm{Ba} / \mathrm{Nb}$ (Figure $11 \mathrm{c}$ ), $\mathrm{Ba} / \mathrm{La}, \mathrm{Ba} / \mathrm{Ce}$ ratios. This correlation is mainly defined by samples from Floreana and San Cristobal, while most of the western volcanoes plot very close to each other. 


\subsection{Discussion}

\subsubsection{Extent of melting and pressure of melt segregation.}

Previous work on Galapagos lavas has suggested that the variation in trace and major elements can be used to infer the extent of melting and the pressure of melt segregation (Geist, 1992, White et al, 1993). These observations are in direct contradiction with several results found in this work. Namely, the correlations between $\mathrm{Nb} / \mathrm{Zr}$ ratios and $\mathrm{Sr}, \mathrm{Nd}$ and $\mathrm{Pb}$ isotopes are difficult to explain solely by different extents of melting (Figure 8). Kurz and Geist, (1999) found a correlation between $\mathrm{Nb} / \mathrm{La}$ and $\mathrm{Nd}$ isotopes, and stated that the variation in $\mathrm{Nb} / \mathrm{La}$ ratios was a result of source heterogeneity. In this case, it can be argued that the extent of melting was sufficiently high and that $\mathrm{Nb}$ and La bulk partition coefficient $\left(\mathrm{D}_{\mathrm{Nb}}, \mathrm{D}_{\mathrm{La}}\right)$ are low and close enough for the lavas to have $\mathrm{Nb} / \mathrm{La}$ ratios similar to that of their source (assuming simple batch melting process). In contrast, the $\mathrm{D}_{\mathrm{Nb}}$ and $\mathrm{D}_{\mathrm{Z}}$ are not that similar, especially during melting in the garnet stability field, making it difficult to use the previous reasoning regarding the correlation between isotopes and $\mathrm{Nb} / \mathrm{Zr}$ ratios. The difference between $\mathrm{Nb} / \mathrm{La}$ and $\mathrm{Nb} / \mathrm{Zr}$ can be seen in Figure 12. The samples define two trends: one is steep and contains most of the lavas, the other is more shallow and defined mainly by the Floreana samples. These two trends are compared with two simple batch melting models for garnet and spinel peridotite. However, the correlation between isotopes, $\mathrm{Nb} / \mathrm{La}$ and $\mathrm{Nb} / \mathrm{Zr}$, except for Floreana, suggests that most of the trace element variations are controlled by either mixing of melts or mixing of mantle sources. Also, this

hypothesis is consistent with the observed correlation between $\mathrm{La} / \mathrm{Sm}_{\mathrm{PM}, 8}$ and $\mathrm{Sr}, \mathrm{Nd}$ and $\mathrm{Pb}$ isotopic ratios averaged by volcano (Geist, 1992; White et al., 1993). The hypothesis of mixing of mantle sources requires an extra step: lavas with progressively more enriched isotopes (high $\mathrm{Sr}, \mathrm{Pb}$, and low $\mathrm{Nd}$ isotopic ratios) have higher $\mathrm{Nb} / \mathrm{La}$ and $\mathrm{Nb} / \mathrm{Zr}$, indicating a lower extent of melting for a more enriched source. Therefore, the correlation between $\mathrm{Nb} / \mathrm{Zr}$ ratios and isotopes (Figure 8) requires the extent of melting to be inversely proportional to the fertility of the source.

The model for melting in the garnet stability field seems to reproduce the Floreana trend. The similarity between the Floreana trend and the melting model brings us to a second of the contradiction with previous papers. Specifically, the flat MREE to HREE pattern in the Floreana lavas (Figure 4b) has been traditionally used as an indication of melting in the spinel stability field (White et al., 1993). As we mentioned before, the low MREE/HREE ratios appear to be related more to the depletion of MREE than to changes in 
the HREE (Figure 5). Floreana basalts have similar LREE/HREE ratios to lavas from Fernandina (Figure $4 \mathrm{~b}$ and 5); this result is unexpected, assuming that the two suites of lavas were segregated from different depths (spinel and garnet stability field, respectively), and have undergone different extents of melting. The concave upward REE pattern of Floreana lavas, with enriched LREE and depleted MREE and HREE at relatively low total REE contents, is not easy to reproduce by simple melting models. However, a reasonable way to reproduce the pattern is by mixing between magmas produced by low extent of melting from a fertile source, segregated from the garnet stability field, and magmas produced by moderate extents of melting from a depleted source, segregated from the spinel stability field (Figure 13a). The high trace element content of the magma produced by a low extent of melting controls the budget of the most incompatible elements, and therefore dominates the isotopic composition of the mixture. Thus, melting processes in Floreana basalts seem to have displaced some of the incompatible trace elements ratios (e.g., $\mathrm{Nb} / \mathrm{Zr}$ ) away from the overal mixing trend (Figure 8 and 12).

The flat REE patterns observed in lavas from San Cristobal and Santa Cruz can be explained in the same manner as the Floreana basalts (Figure 13b). These simple models illustrate that although the HREE may not reveal any indication of garnet, the mixture encodes the garnet signature in the most incompatible elements such as U/Th ratios. In contrast to the lavas from the eastern islands, all the western volcanoes show steep REE pattern suggesting melting in the garnet stability field (White et al., 1993). Basalts from Wolf and Darwin volcanoes have high MREE/HREE ratios but low LREE/HREE ratios (Figure $4 a$ ). This tendency can be explained either by low extent of melting from a previously depleted mantle source or by magma mixing. In any case, the steep REE pattern is an indication of melting in the garnet stability field. Either hypothesis is consistent with the depleted isotopic composition observed in these lavas.

The high $\left({ }^{230} \mathrm{Th} /{ }^{238} \mathrm{U}\right)$ disequilibrium found in Galapagos lavas (greater than 1 for all the samples analyzed) indicates fractionation of Th from $U$ during magmatic processes (Figure 10a). Based on experimental data, the observed Th-U fractionation in Galapagos melts can be produced by melting in the presence of garnet (Beattie, 1993; LaTourrette et al., 1993, Hauri et all., 1994; Salters and Longhi, 1999). This is in agreement with our previous interpretation of the REE patterns and trace element ratios. Especially in the case of Floreana and San Cristobal lavas, which have flat REE patterns, the $\left({ }^{230} \mathrm{Th} /{ }^{238} \mathrm{U}\right)$ ratios 
are much greater than $1(\approx 1.8$ and $\approx 1.4$ respectively) reinforcing the hypothesis of mixing between magmas derived from both the garnet and spinel stability fields.

In the Th-U isochron diagram, Galapagos lavas, with the exception of Florena and San Cristobal, define a quasi linear trend between MORB (GSC-EPR $9^{\circ} \mathrm{N}$ ) at one end, and Pinta at the other extreme (Figure $10 \mathrm{a}$ and $\mathrm{b}$ ). The positive correlation between $\left({ }^{230} \mathrm{Th} /{ }^{232} \mathrm{Th}\right)$ and $\left({ }^{238} \mathrm{U} /{ }^{232} \mathrm{Th}\right)$ can be accounted for in the same way as the $\mathrm{Nb} / \mathrm{La}-\mathrm{Nb} / \mathrm{Zr}$ trend and the REE; namely, by mixing of magmas generated from a fertile and a depleted source or by mixing of these mantle sources. As before, the second case would require an inverse correlation between the extent of melting and the fertility of the source. Moreover, it would also require that the effect of melt transport on $\left({ }^{230} \mathrm{Th} /{ }^{232} \mathrm{Th}\right)$ was either insignificant, or equivalent, for all the islands. Thus, the hypothesis of mixing mantle sources requires more restricted conditions than magma mixing. The correlation between $\left({ }^{230} \mathrm{Th} /{ }^{232} \mathrm{Th}\right)$ and $\mathrm{Sr}$ and $\mathrm{Nd}$ isotope ratios (Figure $11 \mathrm{a}$ ) or $\mathrm{Sr}, \mathrm{Nd}$ and $\mathrm{Pb}$ averaged by volcano (not shown) obtained from White et al., (1993) suggests that the Th isotope composition represents either the Th isotope composition of the lavas produced by mixing, or the isotopic composition of their mantle sources.

$\left({ }^{230} \mathrm{Th} /{ }^{238} \mathrm{U}\right)$ does not correlate with any geochemical indicator of the extent of melting. The lack of correlation suggests that the variation in the extent of disequilibrium is controlled by a combination of melting, melt transport and mixing processes. Although $\mathrm{Ba} / \mathrm{La}, \mathrm{Ba} / \mathrm{Ce}$ and $\mathrm{Ba} / \mathrm{Nb}$ ratios correlate with $\left({ }^{230} \mathrm{Th} /{ }^{238} \mathrm{U}\right)$, these ratios also define positive trends with $\mathrm{Sr}$ and $\mathrm{Pb}$ isotopes suggesting that the variation in the ratios is produced mainly by mixing.

To estimate the extent of melting for Galapagos lavas using $U$ decay series isotopes is not an easy task. This is mainly because $\left({ }^{230} \mathrm{Th} /{ }^{232} \mathrm{Th}\right)$ could indicate the isotopic ratio in the mantle source, the conditions of melt transport (Elliot, 1997), or mixing processes (Lundstrom et al., 1998). Samples from Cerro Azul have a variation in $\mathrm{La} / \mathrm{Yb}_{\mathrm{PM}}$ (from 2.66 to 5.98$)$ and in $\left({ }^{230} \mathrm{Th} /{ }^{238} \mathrm{U}\right.$ ) (from 1.240 to 1.374$)$ at similar $\left({ }^{230} \mathrm{Th} /{ }^{232} \mathrm{Th}\right.$ ) and similar $\mathrm{Sr}, \mathrm{Nd}$ and $\mathrm{Pb}$ isotope ratios. The simplest interpretation of the data is that in Cerro Azul, the $\left({ }^{230} \mathrm{Th} /{ }^{238} \mathrm{U}\right)$ of the lavas is mainly controlled by the extent of melting of the mantle source. More data will be necessary to evaluate this hypothesis. Although it would be premature to estimate the extent of melting, given the complexities of the data, it is clear from the measured $\left({ }^{230} \mathrm{Th} /{ }^{238} \mathrm{U}\right)$ disequilibrium that the mantle sources with higher $\mathrm{Sr}$ and 
$\mathrm{Pb}$ and lower $\mathrm{Nd}$ isotope ratios represented by Floreana and Pinta lavas have melted to a much lower extent than the MORB-like sources supplying the Wolf and Darwin volcanoes. Regardless of the assumptions made or melting model used, disequilibrium of 50 to $80 \%$ indicate that the extent of melting for Pinta and Floreana has been small (0.5 to 2\%) compare to that for Wolf and Darwin volcanoes (5 to 7\%). Moreover, all analyzed Galapagos lavas seem to have melted, or have a component (in the mixture) that melted, in the garnet stability field.

\subsubsection{Seeing through melting and the mixing, to source characteristics.}

Giving the complexity of Galapagos lavas it is difficult to make firm statements about the mantle source. However, trace element ratios seems to show certain features that are not explained either by variable extents of melting or by mixing. For example, the correlation between $\mathrm{Nb} / \mathrm{La}$ ratios and $\mathrm{He}$ and $\mathrm{Nd}$ isotopes suggest that the plume mantle source have a positive anomaly in $\mathrm{Nb}$ and $\mathrm{Ta}$ or that the mantle melts in the precense of mineral phases that would fractionate $\mathrm{Nb}$ from elements with similar compatibility (Kurz and Geist, 1999, Fitton, et al., 1998). In addition to $\mathrm{Nb} / \mathrm{La}$, also $\mathrm{Ti} / \mathrm{Ti}{ }^{*}, \mathrm{~K} / \mathrm{Rb}$ correlate with isotopes, even with ${ }^{3} \mathrm{He} /{ }^{4} \mathrm{He}$ and $\left({ }^{230} \mathrm{Th} /{ }^{232} \mathrm{Th}\right.$ ) (Figure 7 and $11 \mathrm{~b}$ ). If high ${ }^{3} \mathrm{He} /{ }^{4} \mathrm{He}$ ratios are a good indicator of the plume source, it is then unavoidable to suggest that the plume mantle has positive anomalies of $\mathrm{Nb}$ and $\mathrm{Ti}$ and negative anomalies of $\mathrm{K}$. Note that we used $\mathrm{Nb} / \mathrm{La}$ and $\mathrm{K} / \mathrm{Rb}$ as approximations to the $\mathrm{K}$ and $\mathrm{Nb}$ anomalies, because both elements are situated next to each other in the normalized plots the measured $\mathrm{Nb} / \mathrm{Nb}^{*}$ and $\mathrm{K} / \mathrm{K}^{*}$ are influenced by the $\mathrm{K}$ and $\mathrm{Nb}$ contents respectively. We also detected negative $\mathrm{Y}$ anomalies, but they do not correlate as well with the isotopes as do the other anomalies. These various trace element anomalies appear to decrease toward the eastern islands where the trace element patterns are flatter (low MREE/HREE, low $\mathrm{Hf} / \mathrm{Lu}$ ) and the isotopic ratios become more depleted, suggesting an increase in the proportion of MORB (asthenospheric) component in the mixture (Figure 6). Finally, all the lavas, except those that have fractionated plagioclase, have $\mathrm{Sr} / \mathrm{Sr}^{*}$ higher than 1 . In contrast to the $\mathrm{K}, \mathrm{Nb}, \mathrm{Y}$ and $\mathrm{Ti}$ anomalies, the $\mathrm{Sr} / \mathrm{Sr}^{*}$ anomalies are higher in lavas from the eastern islands. The $\mathrm{Sr}$ anomaly does not correlate with isotopes, most probably because the lavas in the western volcanoes have fractionated plagioclase, which decreases this anomaly. For $\mathrm{Sr} / \mathrm{Sr}^{*}>1$, the anomaly does not correlate with $\mathrm{Eu} / \mathrm{Eu}^{*}$ or $\mathrm{CaO} / \mathrm{Al}_{2} \mathrm{O}_{3}$ ratios suggesting that the anomaly is not produced by plagioclase accumulation, but is probably related to the mantle source composition. 
As before, Floreana seems to be an exception, sharing characteristics from both the western volcanoes, (high ${ }^{3} \mathrm{He} /{ }^{4} \mathrm{He}$ ratios, positive anomaly of Ti), and the eastern islands (flat REE, small to nonexistent anomalies of $\mathrm{Y}$ and $\mathrm{K}$, and a large $\mathrm{Sr}$ anomaly). Moreover, Floreana lavas are enriched in $\mathrm{Ba}$ and depleted in $\mathrm{Th}$ and $\mathrm{U}$ relative to elements of similar incompatibility (Figure 4a). We believe the dichotomy observed in Floreana is produced by mixing magmas representing very low degree melts from an enriched source, and moderate degree melts from a depleted source. Thus, in Floreana many of the characteristics ascribed to either asthenospheric or plume mantle sources are clouded by melting processes, which seem to have caused the ratios of incompatible trace element $(\mathrm{Nb} / \mathrm{Zr}, \mathrm{Th} / \mathrm{U})$ to diverge from the mixing trends.

The trace element anomalies observed in Galapagos lavas are also common in Hawaii and Iceland (Fitton, et al 1998, Hofmann, 1998 and Sobolev et al, 1998), all known areas with high ${ }^{3} \mathrm{He} /{ }^{4} \mathrm{He}$ ratios. The origin of the $\mathrm{Nb}, \mathrm{Ti}, \mathrm{Sr}, \mathrm{K}$ and $\mathrm{Y}$ anomalies in the Galapagos mantle plume is controversial. However, the enrichment of HFSE and $\mathrm{Sr}$, the depletion in $\mathrm{K}$, and the correlation with isotopes, especially ${ }^{206} \mathrm{~Pb} /{ }^{204} \mathrm{~Pb}$ ratios (up to 19.5 in volcanoes from Isabela) are consistent with the model that invokes tapping of recycled oceanic crust (Hofmann, 1982; Hofmann and White, 1980). Even the characteristics of Floreana (Ti, Nb and Sr enrichments, Th-U depletions, and ${ }^{206} \mathrm{~Pb} /{ }^{204} \mathrm{~Pb}$ ratios up to 20) are consistent with the hypothesis of recycled oceanic crust gabbros proposed by Sobolev et al. (1998) and Hofmann, (1998) for Hawaii and Iceland. If this is the case, the correlation between the trace element anomalies (index of ocean crust recycling) and the ${ }^{3} \mathrm{He} /{ }^{4} \mathrm{He}$ ratios (indicator of undegassed mantle) is puzzling. One simple and circumstantial explanation could be the thermal entrainement of undegassed mantle in a plume formed by recycled material (Hart et al., 1992). On the other hand, minerals such as $\mathrm{Ca}$ and Mg-Perovskites could fractionate HFSE and $\mathrm{K}$ from other incompatible elements (Kato et al., 1988, Shimizu pers. comm., 1999). Thus, a second hypothesis is that the correlation between the trace element anomalies (index of Ca-Perovskite fractionation) and ${ }^{3} \mathrm{He} /{ }^{4} \mathrm{He}$ ratios (undegassed mantle) could be a simple indication of the early Earth differentiation. However, the near primitive mantle $\mathrm{Ba} / \mathrm{U}$ ratios for lavas from Fernandina islands, which have the highest ${ }^{3} \mathrm{He} /{ }^{4} \mathrm{He}$ ratios, are inconsistent with both the above hypotheses. The relative uniformity and near primitive mantle values of ratios such as $\mathrm{Ce} / \mathrm{U}$ and to lesser extent $\mathrm{Ba} / \mathrm{U}, \mathrm{Ba} / \mathrm{Ce}$ in OIBs compared to MORB is surprising and challenges both the recycling and the early Earth differentiation hypothesis (Halliday et al, 
1995). Finally, more work is required to distinguish the effects of recycling from those of local assimilation of oceanic crust. Local assimilation could be an important source of geochemical variation in Galapagos lavas, where the oceanic crust platform ranges up to 18 $\mathrm{km}$ in thickness (Feighner and Richards, 1994). Nevertheless, the high ${ }^{206} \mathrm{~Pb} /{ }^{204} \mathrm{~Pb}$ (up to 20, White et al., 1993) and the high ${ }^{3} \mathrm{He} /{ }^{4} \mathrm{He}$ isotopes, (up to 30, Kurz and Geist, 1999) are not easily explained by interaction of Galapagos magmas with a young lithosphere $(<10$ Ma).

\subsubsection{Mantle porosity and upwelling velocities}

In the last 10 years, a series of elaborate models were developed to explain the effects of melting and melt transport on $U$ decay series isotopes. There are two endmember models: dynamic melting and equilibrium porous flow. Both models consider that melting processes in the presence of garnet is responsible for the Th- $U$ fractionation producing lavas with higher $\mathrm{Th} / \mathrm{U}$ ratios than those of their mantle source (Beattie, 1993; LaTourrette et al., 1993, Hauri et all.,1994; Salters and Longhi, 1999).

Dynamic melting was applied to U series isotopes by McKenzie (1985) and modified by Williams and Gill (1989). It considers that the melting process can be described by accumulated fractional melting with a threshold porosity (Shaw, 1970). In this model, the melt is extracted continuously and accumulated in chemical isolation from the solid residue, with the result that $\mathrm{Th}$ and $\mathrm{U}$ are extracted from the solid very early during the melting.

The second model, equilibrium porous flow (EPF), was proposed by Spiegelman and Elliott (1993). It postulates that as the melt migrates, it reacts with the solid residue, reaching equilibrium at each step. This process allows the $U$ to remain in the solid matrix for a longer time, producing greater disequilibrium than in the dynamic melting model. ${ }^{230} \mathrm{Th}$ cannot remain in the melting columns longer than about 6 half-lifes. Therefore, a slow effective velocity in a long melting column will erase the extent of disequilibrium due to the fast decay of ${ }^{230} \mathrm{Th}$ relative ${ }^{238} \mathrm{U}$. The beauty of EPF is that the ${ }^{230} \mathrm{Th}$ excesses are controlled both by melting and by differential (melt/matrix) transport. At the bottom of the column, for degrees of melting comparable to the bulk partition coefficient (D), the initial excesses are large, principally controlled by the chemical fractionation during melting. As the extent of melting gets larger, this effect disappears and the transport processes dominate the ingrowth. As long as the ${ }^{238} \mathrm{U}$ parent isotope continues to spend more time in the 
column than its daughter, the excess will persist even to high extent of melting (Spiegelman and Elliott, 1993). Thus, in contrast to dynamic melting, in EPF the length of the melting column influences the resulting ${ }^{230} \mathrm{Th}$ excesses. At slow upwelling rates and faster effective velocity for Th than $U$, long melting columns will produce larger ${ }^{230} \mathrm{Th}$ excesses than shorter columns. At present, there is no clear evidence that would allow us to choose between dynamic or equilibrium porous flow models. The only reason we consider dynamic melting more realistic is that there is no evidence in major and trace element data for basalt and peridotite that support the hypothesis that the melt equilibrate with the surrounding mantle matrix as proposed by (Spiegelman and Elliot, 1993).

We have applied both the dynamic melting and equilibrium porous flow models to the Galapagos plume. The main objective is to derive information on mantle porosity and upwelling rates. Both models should be considered approximations, due to the uncertainties in the mineral modes, partition coefficients, mantle compositions, melt productivity, etc. We used two sets of partition coefficient (Beattie, 1993; LaTourrette et al., 1993). The bulk partition coefficients (D) define the maximum obtainable disequilibrium for any model, which is the ratio between the parent and daughter bulk partition coefficient. Moreover, the Ds control the effective velocity of the element and the rate at which the element is transfered from the solid to the melt.

In general, past $U$ series work on magmatic processes has been done using garnet/clinopyroxene ratios for the mantle source that appear to be high $(0.12 / 0.08$, Beattie, 1993) compared to ratios obtained from melting experiments in the garnet stability field $(0.06 / 0.25$, Walter, 1998). This observation constrains either the source composition (peridotite versus eclogite-pyroxenite) or the partition coefficients to be used. For example, to obtain $80 \%$ disequilibrium as observed in the Floreana lavas, assuming Walter's mineral modes, we are forced to use Beattie, (1993) partition coefficients. Any other partition coefficient set will not reproduce the observed disequilibrium $\left[\left({ }^{230} \mathrm{Th} /{ }^{238} \mathrm{U}\right)=1.8\right]$ because the ratio between the parent/daughter bulk partition coefficient set is smaller than 1.8 . On the other hand, if we use La'Tourrette's partition coefficients, the observed disequilibrium would require the existence of eclogite (garnet/clinopyroxene $\approx 0.5 / 0.5$ ) in the melting column.

For these exercises, we have assumed the generally used garnet/clinopyroxene $=$ 0.12/0.08 ratios (Beattie, 1993). Both models applied here utilize modal, one-stage 
melting, that is, melting occurs only in the garnet stability field (Figure 14, 15). Moreover, in the EPF model ${ }^{230} \mathrm{Th}$ excesses are dependent on the length of the column. Therefore, we show the results using melting column lengths varying from 0.5 to $10 \%$ melting for Floreana, Pinta, and Fernandina respectively (Figure 15). In contrast, if we utilize nonmodal melting models, the source mineral modes of Walter (1998), and consider two stage melting models, in the garnet and spinel field, to obtain the same disequilibrium the output of the model will result in a smaller mantle porosity and slower upwelling rates. Moreover, the EPF model will require longer melting columns, starting at greater depth, and will involve larger extent of melting. Thus, the results obtained here are an upper bound for the mantle porosity and upwelling velocities and a minimum limit for the length of the melting column in the Galapagos plume.

Figure 14 and 15 show contours of constant ${ }^{230} \mathrm{Th}$ excess as a function of the mantle porosities and upwelling velocities for both Dynamic melting and EPF. Each contour represent the maximum ${ }^{230} \mathrm{Th}$ excess found in each volcano or island. The first important observation from Figure 14 is that lavas from Darwin and Wolf volcanoes, or even from Santiago island, give faster apparent mantle upwelling velocities and larger porosities than Fernandina which is the assumed center of the hot-spot. The lower ${ }^{230} \mathrm{Th}$ excess in those lavas compared with Fernandina basalts is mainly produced by the larger MORB component involved in the mixing for Wolf and Darwin volcanoes. Therefore, from these results we can argue that the smaller ${ }^{230} \mathrm{Th}$ excesses found in lavas from Darwin and Wolf indicate:

1) the MORB-like mantle below Darwin and Wolf volcanoes upwell faster than the center of the plume (Fernandina). This hypothesis is unlikely, because the center of the plume is considered to be the hottest and therefore should upwell with the fastest velocities.

2) The mantle below Darwin and Wolf has higher porosity than that of Fernandina. Again this hypothesis seems unlikely; because the center of the plume (Fernandina) should be the hottest, and lavas from Fernandina indicate a more fertile mantle source (higher $\mathrm{Sr}, \mathrm{Pb}$ and lower $\mathrm{Nd}$ isotope ratios) than those from Darwin and Wolf, we would expect higher extent of melting, and therefore higher porosity in the mantle source of Fernandina than in those of Darwin and Wolf. 
3) The lower ${ }^{230} \mathrm{Th}$ excess in lavas from Darwin and Wolf volcanoes than those of Fernandina are produced by mixing between lavas originated from the plume mantle with lavas from the MORB mantle. Because we do not know the end-member that represent the MORB component we could argue that the MORB end member was in secular equilibrium. Therefore, the lower ${ }^{230} \mathrm{Th}$ excess could be the result of simple mixing with no indication of mantle porosity or upwelling velocities. It cannot be unambiguously argued that the ${ }^{230} \mathrm{Th}$ excess in Darwin and Wolf lavas indicates faster upwelling velocities or larger porosities than that for Fernandina.

Thus, we will consider here only Fernandina as the best example to establish the melting conditions in the plume. We choose Fernandina as representative of the plume because its lavas have the highest ${ }^{3} \mathrm{He} /{ }^{4} \mathrm{He}$, indicative of its proximity to the present position of the plume (Kurz and Geist, 1999). We will also consider the melting conditions for Pinta and Floreana samples, because they exemplify lavas erupted on the thin lithosphere, which represent the lowest extents of melting, and the smallest contamination with MORB in the archipelago (Figure 10).

To reproduce the measured $\left({ }^{230} \mathrm{Th} /{ }^{238} \mathrm{U}\right)$ in Fernandina, Pinta and Floreana dynamic melting will require mantle upwelling velocities of approximately $8.5 \times 10^{-3}$, $4.5 \times 10^{-3}, 2 \times 10^{-3} \mathrm{~m} / \mathrm{y}$ and porosities of $3 \times 10^{-3}, 2 \times 10^{-3}, 1 \times 10^{-3}$, respectively. In contrast, the EPF allows faster upwelling mantle velocities than dynamic melting (approximately $3 \times 10^{-2}$, $1 \times 10^{-2}, 5 \times 10^{-3} \mathrm{~m} / \mathrm{y}$ and similar porosities of $3 \times 10^{-3}, 1.5 \times 10^{-3}, 1 \times 10^{-3}$ respectively). Two important points can be obtained from this exercise:

1) The mantle upwelling velocity for the Galapagos plume (Fernandina) is extremely slow ( $\leq 1$ to $3 \mathrm{~cm} / \mathrm{y}$ ), compared to the tholeiites from Hawaii (40 to $100 \mathrm{~cm} / \mathrm{y}$, Sims et al., 1999, using same bulk Ds and modal proportions).

2) Very slow mantle upwelling for Pinta $(0.5$ to $1 \mathrm{~cm} / \mathrm{y})$ and Floreana $(0.2$ to $0.5 \mathrm{~cm} /$ year) indicates that the plume is dragged approximately toward the east almost horizontally after impinging in the lithosphere, thus limiting the decompression and producing low extent of melting.

Ito et al. (1997), presented a three-dimensional numerical model of hot-spot ridge interaction for the Galapagos and GSC, with variable viscosities. The model match the residual bathymetry and mantle Bouguer anomaly along isochrons. The amplitude of the 
gravity anomalies can be explained by a plume source 100 to $200 \mathrm{~km}$ in radius and a temperature anomaly of 100 to $50^{\circ} \mathrm{C}$ respectively. Thus, the plume is only mildly buoyant (buoyancy flux of $2 \times 10^{3} \mathrm{~kg} \mathrm{~s}^{-1}$ ). Considering the case of a plume source $200 \mathrm{~km}$ in radius and a temperature anomaly of $50{ }^{\circ} \mathrm{C}$, the plume volume flux and the mantle upwelling velocities modeled by Ito et al. are $\approx 9.1 \times 10^{6} \mathrm{Km}^{3} / \mathrm{Ma}$. and $\approx 7 \mathrm{~cm} / \mathrm{y}$ respectively. Thus, the mantle upwelling velocities obtained from modeling the residual bathymetry and mantle bouger anomaly are slightly higher than the upwelling mantle velocities of $\approx 3 \mathrm{~cm} / \mathrm{y}$ estimated from $\left({ }^{230} \mathrm{Th} /{ }^{238} \mathrm{U}\right)$ disequilibrium for the center of the hotspot (Fernandina). Both studies (the numerical model and the ${ }^{230} \mathrm{Th}$ excesses) indicate that the Galapagos plume is quite weak, with a plume temperature anomaly of the order of 100 to $50^{\circ} \mathrm{C}$. The agreement between the numerical model for Galapagos by Ito et al.,(1997) and our work here confirms the correlation observed by Chabaux and Allègre, (1994) between ${ }^{230} \mathrm{Th}$ excesses and buoyancy flux.

Many of the characteristics observed in the Galapagos islands can be explained by different aspects of the interaction between the plume, the GSC and the Feighner and Richards' fault ( $90^{\circ} 50^{\prime}$ transform fault?). Bathymetric and gravimetric data indicate that this fault divides the archipelago into two sectors: the west sector with an old, thick and cold lithosphere ( $\approx 10 \mathrm{Ma}, 12 \mathrm{~km}$ elastic thickens) and an eastern sector with a young, thin and warm lithosphere $(\approx 5 \mathrm{Ma}, 6 \mathrm{~km}$ elastic thickness) (Feighner and Richards, 1994). The plume impinges under the western sector, where the sloping lithosphere forms a rheological boundary layer (RBL) that thins toward the ridge. The plume is dragged by the moving plate toward the SE, into the eastern sector, where the lithosphere is thin and relatively flat. Fluid dynamics laboratory experiments found a correlation between the magnitude of the RBL slope, and the proportion of material that the plume feeds to the nearby ridge (Kincaid et al, 1995). The three-dimensional variable-viscosity experiment indicates that the greater the RBL slope, the more effectively it diverts the buoyant low viscosity plume material toward the ridge. In the western sector, the plume is warmer and less viscous, and the lithosphere has a more pronounced slope than in the east. To the east of the fault, the lower thermal difference between the flatter lithosphere and the colder plume facilitates the dragging of the plume away from the GSC. Although the effect of the lithosphere on the plume may be small because the Galapagos is a mildly buoyant plume (Ito et al., 1997), the ability of the lithosphere to divert the plume toward the ridge will be larger in the western sector than in the eastern sector. Thus, this different behavior on 
opposite sides of the fault can explain why the geochemical anomaly does not occur at its closest position to the Galapagos archipelago, but to the northwest, at the intersection of the Darwin-Wolf lineament and the GSC. Moreover, the lower thermal difference between the flatter lithosphere and the colder plume in the eastern sector facilitates the dragging of the plume away from the GSC and allows the upwelling MORB material to fill the central area of the Archipelago producing the "horse shoe pattern".

After impinging under the western sector, the plume cools and is dragged toward the east, moving across the fault. The west to east difference in thickness of the lithosphere $(\approx 6 \mathrm{~km})$ allows the relatively cold plume, that was moving almost horizontally, to move upward, producing decompression and a low extent of melting (approximately 2\%, assuming melting rate of $0.3 \% / \mathrm{km}$ and a $6 \mathrm{~km}$ distance). As the dragged plume moves to the SE, the central part of the archipelago will be underlain largely by thermally entrained asthenospheric mantle, as postulated by Richard and Griffiths (1989). As with the plume, when the asthenosphere crosses the fault, decompression and melting occurs. Thus, the effect of the transform fault and the abrupt thinning of the lithosphere may account for the broad distribution of the volcanoes and the long periods of eruption in the eastern sector. Moreover, this process can explain the negative Bouguer anomaly observed in the center of the archipelago (Case et al., 1973, Feighner and Richards, 1994). The effect of transform faults on melting was proposed by Reynolds and Langmuir (1997) to explain the trace element composition of MORB erupting close to the intersection of the MARK area with the Kane transform fault. We believe that consideration of variations in lithospheric thickness and transform fault effects are of utmost importance in understanding Galapagos magmatism.

\subsection{Conclusions}

The correlation between isotopes and trace element ratios (such as $\mathrm{Nb} / \mathrm{La}, \mathrm{Nb} / \mathrm{Zr}$, $\mathrm{Ba} / \mathrm{La}, \mathrm{K} / \mathrm{Rb}$ and $\mathrm{Ba} / \mathrm{Ce}$ ) suggests that most of the trace element variations in the Galapagos are controlled by mixing of magmas from at least two different mantle sources. The extent of melting represented by the extreme components of the mixing seems to be inversely proportional to the fertility of the sources. This simple model illustrates that such a mixture carries a garnet signature in the most incompatible elements (such as $\mathrm{U}, \mathrm{Th}, \mathrm{Nb}, \mathrm{Zr}$ ) even though the variation of the MREE to HREE does not reveal any indication of melting in the garnet stability field. 
The high $\left({ }^{230} \mathrm{Th} /{ }^{238} \mathrm{U}\right)$ disequilibrium found in Galapagos (ranging from 1.16 to 1.81), indicates that melting occurs in the garnet stability field in agreement with the trace element results. The positive correlation between $\left({ }^{230} \mathrm{Th} /{ }^{232} \mathrm{Th}\right)$ and $\left({ }^{238} \mathrm{U} /{ }^{232} \mathrm{Th}\right)$, with ${ }^{230} \mathrm{Th}$ excesses decreasing toward higher $\left({ }^{230} \mathrm{Th} /{ }^{232} \mathrm{Th}\right)$ ratios, can be accounted for by mixing of magmas generated by low extents of melting from a fertile source with magmas produced by relatively large extents of melting from a depleted source. The correlations between $\left({ }^{230} \mathrm{Th} /{ }^{232} \mathrm{Th}\right)$ and $\mathrm{Sr}, \mathrm{Nd}$ and $\mathrm{Pb}$ isotopes confirm that the $\mathrm{Th}$ isotopic ratios are mainly source-controlled and are the result of magma mixing between the plume and asthenosphere melts.

Correlation between $\mathrm{He}$ isotopes and $\mathrm{Ti} / \mathrm{Ti} \mathrm{T}^{*}, \mathrm{~K} / \mathrm{Rb}$ and $\mathrm{Nb} / \mathrm{La}$ ratios suggests that the mantle plume has positive anomalies of $\mathrm{Nb}$ and $\mathrm{Ti}$ and negative anomalies of $\mathrm{K}$. The decrease of these anomalies toward the eastern islands where the trace element pattern are flatter and the isotopic ratios become more depleted, suggests that the increase of the proportion of a MORB component in the mixture tend to erase these anomalies. The origin of the $\mathrm{Nb}, \mathrm{Ti}, \mathrm{Sr}, \mathrm{K}$ and $\mathrm{Y}$ anomalies in the mantle plume of Galapagos is still a matter of debate.

Dynamic melting and equilibrium porous flow models constrain mantle upwelling velocities for the Galapagos plume (Fernandina) to $\leq 3 \mathrm{~cm} / \mathrm{y}$ and maximum porosities of $0.3 \%$, indicating that Galapagos is a mildly buoyant plume; this is consistent with a $3 \mathrm{D}$ numerical model of plume-ridge interaction. Evidence for very slow mantle upwelling and low porosity for Pinta $(0.5$ to $1 \mathrm{~cm} / \mathrm{y}$ and $0.15 \%)$ and Floreana $(0.2$ to $0.5 \mathrm{~cm} / \mathrm{y}$ and $0.1 \%$ ) supports the hypothesis that the lateral transport of the plume across the $90^{\circ} 50^{\prime}$ transform fault produced additional slow upwelling and further small extent of melting.

Dynamic melting and equilibrium porous flow models may give erroneous estimations of mantle porosity and upwelling rates when the suite of lavas has undergone mixing processes. 


\subsection{References}

Allègre C. J. and Condomines M., Fine chronology of volcanic processes using ${ }^{238} \mathrm{U}^{230} \mathrm{Th}$ systematics. Earth Planet. Sc. Lett. 28: 395-406, 1976.

Beattie P. D., Uranium-thorium disequilibria and partitioning on melting of garnet peridotite. Nature 363: 63-65, 1993.

Bourdon B., Zindler A., Elliott T. and Langmuir C. H., Constraints on mantle melting at mid-ocean ridges from global ${ }^{238} \mathrm{U}_{-}^{230} \mathrm{Th}$ disequilibrium data. Nature, 384: 231-235, 1996.

Bourdon B., Langmuir C. H. and Zindler A., Ridge-hotspot interaction along the MidAtlantic ridge between $37^{\circ} 30^{\prime}$ and $40^{\circ} 30^{\prime} \mathrm{N}$ : the U-Th disequilibrium evidence. Earth Planet. Sc. Lett. 142: 175-189, 1996.

Case J. E., Ryland S. L., Simkin T. and Howard K. A., Gravitational evidence for a lowdensity mass beneath the Galapagos islands. Science 181: 1040-1042, 1973.

Chabaux F. and Allègre C. J., ${ }^{238} \mathrm{U}^{230} \mathrm{Th}^{2}{ }^{226} \mathrm{Ra}$ disequilibria in volcanics: A new insight into melting conditions. Earth Planet. Sc. Lett. 126: 61-74, 1994.

Cohen A. S. and O'Nion R. K., Melting rates beneath Hawaii: Evidence from uranium series isotopes in recent lavas. Earth Planet. Sc. Lett. 120: 169-175, 1993.

Condomines M., Hemond C. and Allègre C. J., U-Th-Ra radioactive disequilibrium and magmatic processes. Earth Planet. Sc. Lett. 90: 243-262, 1988.

Darwin C. The voyage of the Beagle, 524 pp, Doubleday, New York, 1860.

Elliot T., Fractionation of $U$ and Th during mantle melting: a reprise. Chem. Geol. 139: 165-183, 1997.

Elliot T., Plank T., Zindler A., White W. and Bourdon B., Element transport from slab to volcanic front at the Mariana arc. J. Geophys. Res 102: 14,991-15,019, 1997.

Feighner M. A. and Richards M. A., Lithospheric structure and compensation mechanism of the Galapagos archipelago. J. Geophys. Res 99: 6711-6729, 1994.

Fitton J. G., Hardarson B. S., McBirney A. R. and Kempton P. D., Contrasted styles of plume-ridge interaction in Iceland and Galapagos Islands. (Abst.) Evolution of Ocean Island Volcanoes, GSA, Penrose conference, Galapagos, p 30, 1998.

Geist D. J., White W. M. and McBirney A. R., Plume-asthenosphere mixing beneath the Galapagos archipelago. Nature 333: 657-660, 1988.

Geist D. J., An appraisal of melting processes and the Galapagos hotspot: Major and traceelement evidence. J. Volc. Geotherm. Res. 52: 65-82, 1992.

Geist D. J. and Reynolds R., A field trip guide to the geology of the Galapagos Islands, Evolution of Ocean Island Volcanoes, GSA, Penrose conference, Galapagos, 1998. 
Goldstein S. J., Murrell M. T. and Janecky D. R., Th and U systematics of basalts from the Juan de Fuca and Gorda ridges by mass spectrometry. Earth Planet. Sc. Lett. 96: 134146,1989 a.

Goldstein S. J., Murrell M. T. and Williams R. W., Half life of 229Th. Phys. Rev. C40 2793-2795,1989 b.

Goldstein S. J., Murrell M. T. and Janecky D. R., Delaney J. R. and Clague D. A., Geochronology and petrogenesis of MORB from Juan de Fuca and Gorda ridges by ${ }^{238} \mathrm{U}$ ${ }^{230}$ Th disequilibrium. Earth Planet. Sc. Lett., 109: 255-272, 1992.

Goldstein S. J., Murrell M. T. and Williams R. W., ${ }^{231} \mathrm{~Pa}$ and ${ }^{230}$ Th chronology of midocean ridge basalts. Earth Planet. Sc. Lett., 115: 151-159, 1993.

Goldstein S. J., Perfit M. R., Batiza R., Fornari D. J. and Murrell M. T., Off-axis volcanism at the East Pacific rise detected by uranium-series dating of basalts. Nature 367: 157-159, 1994.

Graham, D. W., Christie D. M., Harpp K. S. and Lupton J. E., mantle plume helium in submarine basalts from the Galapagos Platform. Science 262:2023-2026, 1993.

Hart S. R. and Reid M. R., Rb/Cs fractionation: A link between granulite metamorphism and the S-process. Geochim. Cosmochim. Acta 55:2379-2383, 1991.

Harpp K. S., White W. M. and Duncan R. A., Geochemistry of the Wolf-Darwin lineament and ridge-plume interaction in the Galapagos, Geol. Soc. Aust. Abstr., 27, 44, 1990.

Hauri E. H., Wagner T. P. and Grove T. L., Experimental and natural partitioning of Th, $\mathrm{U}, \mathrm{Pb}$ and other trace elements between garnet, clinopyroxene and basaltic melts. Chem. Geol. 117: 149-166, 1994.

Hawkesworth C. J., Turner S. P., McDermott F., Peate D. W. and van Calstersen P., UTh isotopes in Arc magmas: Implications for element transfer from the subducted crust. Science, 276: 551-555, 1997.

Hémond C., Devey C. W. and Chauvel C., Source compositions and melting processes in the Society and Austral plumes (South Pacific Ocean): Element and isotope ( $\mathrm{Sr}, \mathrm{Nd}, \mathrm{Pb}$, Th) geochemistry. Chem. Geol. 115:7-45, 1994.

Hey R., Tectonic evolution of the Cocos-Nazca spreading center. Geol. Soc. Am. Bull. 88: 1404-1420, 1977.

Hofmann A. W. and White W. M., Ba, Rb and Cs in the Earth mantle. Z. Naturforsch. 38A: 256-266, 1983.

Hofmann A. W., Mantle plumes from ancient oceanic crust. Earth Planet. Sc. Lett. 57: $421-436,1982$. 
Hofmann A. W., Geochemical signatures of gabbro in Hawaiian basalts and other OIB: recycling or local assimilation? (Abst.) Evolution of Ocean Island Volcanoes, GSA, Penrose conference, Galapagos, p 41, 1998.

Hofmann A. W. and White W. M., The role of subducted oceanic crust in mantle evolution. Carnegie Inst. Washington Yearbook 79: 477-483, 1980.

Holliday A. N., Lee D-C, Tommasini S., Davies G. R., Paslick C. R., Fitton J. G. and James D. E., Incompatible trace elements in OIB and MORB and source enrichment in the suboceanic mantle. Earth Planet. Sc. Lett. 133: 379-395, 1995.

Ito G., Lin J. and Gable C. W., Interaction of mantle plume and migrating mid-ocean ridges: Implications for the Galapagos plume-ridge system. J. Geophys. Res 102:15,403$15,417,1997$.

Kato T., Ringwood A. E. and Irifune T., Experimental determination of element partitioning between silicate perovskite, garnets and liquids: constraints in early differentiation of the mantle. Earth Planet. Sc. Lett. 89: 123-145, 1988.

Kelemen P. B., Shimizu N. and Dunn T., Relative depletion of niobium in some arc magmas and the continental crust: partitioning of $\mathrm{K}, \mathrm{Nb}, \mathrm{La}$ and $\mathrm{Ce}$ during melt/rock reaction in the upper mantle. Earth Planet. Sc. Lett. 120: 111-134, 1993.

Kincaid C., Ito G. and Gable C., Laboratory investigation of the interaction of off-axis mantle plumes and spreading centers. Nature, $376: 758-761,1995$.

Kurz M. D., In-situ production of cosmogenic terrestrial helium and some applications to geochronology. Geochim. Cosmochim. Acta 50: 2855-2862, 1986.

Kinzler R. J. and Grove T. L., Primary magmas of mid-ocean ridge basalts 2 . Applications. J. Geophys. Res 97: 6907-6926, 1992.

Kurz M. D., Colodner D., Trull T. W., Moore R. B. and O'Brien K., Cosmic ray exposure dating with in situ produced cosmogenic ${ }^{3} \mathrm{He}$ : Results from young Hawaiian lava flows. Earth Planet. Sc. Lett. 97: 177-189, 1990.

Kurz M. D., Kenna T., Kammer D., Rhodes J. M. and Garcia M. O., Isotopic evolutin of Mauna Loa volcano: a view from the submarine south west rift. Mauna Loa Revealed:Structure, composition , History and Hazards AGU monograph \#92 (Lockwood J. P. and Rhodes J. M., eds) p 289-306, 1995.

Kurz M. D., Kenna T., Lassiter J. C. and DePaolo D. J., Helium isotopic evolution of Mauna Kea volcano: First results from the $1 \mathrm{~km}$ drill core. J. Geophys. Res 101: 11,781$11,791,1996$.

Kurz M. D. and Geist D. J., Dynamics and evolution of the Galapagos hotspot from helium isotope geochemistry. Geochim Cosmochim Acta (in press), 1999.

Lal D., Cosmic ray labeling of erosion surfaces: In situ nuclide production rates and erosion models. Earth Planet. Sc. Lett. 104: 424-439, 1991. 
LaTourrette T.Z., Kennedy A. K. and Wasserburg G. J., Thorium-uranium fractionation by garnet: Evidence for a deep source and rapid rise of oceanic basalts. Science 261:739$742,1993$.

Layne G. and Sims K., Secondary ion mass spectrometry for the measurement of ${ }^{232} \mathrm{Th} /{ }^{230} \mathrm{Th}$ in Volcanic Rocks". In prep., 1999.

Le Bas M., Le Maître, Streckeisen A. and Zanettin B., A chemical classification of volcanic rocks based on the total alkali-silica diagram. J. Petrology 27:745-750, 1986.

Lundstrom C. C., Gill J. B., Williams Q. and Perfit M., Mantle melting and basalt extraction by equilibrium porous flow. Science, 270: 1958-1961, 1995.

Lundstrom C. C., Williams Q. and Gill J. B., Investigating solid mantle upwelling rates beneath mid-ocean ridges using $\mathrm{U}$-series disequilibria, 1: a global approach. Earth Planet. Sc. Lett. 157: 151-165, 1998.

Macdonald G. A. and Katsura T., Chemical composition of Hawaiian lavas. J Petrology 5: 82-133, 1964.

McBirney A. R. and Williams H., Geology and Petrology of the Galapagos islands. Geological Society of America Memoir, 118: 197 pp, 1969.

McKenzie D., ${ }^{230} \mathrm{Th}^{2}{ }^{28} \mathrm{U}$ disequilibrium and the melting processes beneath ridge axes. Earth Planet. Sc. Lett. 72: 149-157 (1985).

Morgan W. J., Rodriguez, Darwin, Amsterdam...., A second type of hotspot island. J . Geophys. Res 83: 5355-5360, 1978.

Nauman T. and Geist D. J., Generation of alkaline basalt by crystal fractionation of tholeiitic magma. Submitted to Geology 1998.

Reynolds J. R. and Langmuir C. H., Petrological systematics of the Mid-Atlantic ridge south of Kane: Implications for the ocean crust formation. J. Geophys. Res 102: 14,91514,946, 1997.

Richard M. A. and Griffiths R. W., Thermal entrainment by deflected mantle plumes, Nature 342:900-902, 1989.

Rubin K. H. and Macdougall J. D., Th-Sr isotopic relationships in MORB. Earth Planet. Sc. Lett. 114: 149-157, 1992.

Salters V. J. and Longhi J., Trace element partitioning during the initial stages of melting beneath mid-ocean ridges. Earth Planet. Sc. Lett. 166: 15-30, 1999,

Shaw D. M. Trace element fractionation during anatexis. Geochim. Cosmochim. Acta 34:237-243 1970

Schilling J-G, Kingsley R. H. and Devine J. D., Galapagos hot-spot-spreading center system 1. Spatial petrological and geochemical variations $\left(83^{\circ} \mathrm{W}-101^{\circ} \mathrm{W}\right)$. J. Geophys. Res 87: 5593-5610, 1982. 
Sims K. W., DePaolo D. J., Murrell M. T., Baldridge W. S., Goldstein S. J., Clague D. A. and Jull M., Porosity of the melting zone and variations in the solid mantle upwelling rate beneath Hawaii: Inferences from ${ }^{238} \mathrm{U}_{-}{ }^{230} \mathrm{Th}-{ }^{226} \mathrm{Ra}$ and ${ }^{235} \mathrm{U}^{231} \mathrm{~Pa}$ disequilibria. Accepted in Geochim. Cosmochim. Acta, 1999.

Sims K. W., DePaolo D. J., Murrell M. T., Baldridge W. S., Goldstein S. J., Clague D. A. Mechanisms of magma generation beneath Hawaii and Mid-Ocean ridges: Uranium/Thorium and Samarium/Neodymiun isotopic evidence. Science 267: 508-512, 1995.

Sigmarsson O., Short magma chamber residence time at an Icelandic volcano inferred from U-series disequilibria. Nature, 382: 440-442, 1996.

Sobolev A., Hofmann A. W. and Nikogosian I., Anomalous Sr in melt inclusions from Mauna Loa, Hawaii:Fingerprint of recycled gabbro? EOS, Transactions, AGU, S345, 1998.

Spiegelman M. and Elliott T., Consequences of melt transport for uranium series disequilibrium in young lavas. Earth Planet. Sc. Lett. 118: 1-20 1993

Sun S-s and McDonough W. F., Chemical and isotopic systematics of oceanic basalts: Implication for mantle composition and processes. In Magmatism in oceanic basins, Geological Society Special Publication $\mathrm{N}^{\mathrm{o}} 42$, Saunders A. D. and Norry M. J. (eds.), Blackwell Scientific Publications, 1989.

Takazawa E. Geodynamic evolution of the Horoman peridotite, Japan: Geochemical study of lithospheric and asthenospheric processes. Ph.D thesis Massachusetts Institute of Technology, 1996.

Verma S. P. and Schilling, J-G, Galapagos hotspot-spreading center system $2.87 \mathrm{Sr} / 86 \mathrm{Sr}$ and large ion lithophile element variations $\left(85^{\circ} \mathrm{W}-101^{\circ} \mathrm{W}\right)$. J. Geophys. Res 87: 10,838$10,856,1982$.

Volpe A. M. and Goldstein S. J., ${ }^{226} \mathrm{Ra}^{2}{ }^{230} \mathrm{Th}$ disequilibrium in axial and off-axis midocean ridge basalts. Geochim Cosmochim. Acta, 57: 1233-1241, 1993.

Walter M. J., Melting of garnet peridotite and the origin of komatiite and depleted lithosphere. J Petrology 39:29-60, 1998.

White W. M., McBirney A. R. and Duncan R. A., Petrology and geochemistry of the Galapagos Islands: Portrait of a pathological mantle plume. J. Geophys. Res 98: 19,533$19,563,1993$.

Williams R. W. and Gill J. B., Effects of partial melting on the uranium decay series. Geochim. Cosmochim. Acta 53: 1607-1619, 1989. 


\subsection{Table Caption}

Table 1: Representative majors and trace elements and isotope analyses from the published and unpublished data set of Kurz. $\mathrm{Pb}$ isotopes are reported relative to value for NBS $981{ }^{206} \mathrm{~Pb} /{ }^{204} \mathrm{~Pb}=16.9356 ;{ }^{207} \mathrm{~Pb} /{ }^{204} \mathrm{~Pb}=15.4891$ and ${ }^{208} \mathrm{~Pb} /{ }^{204} \mathrm{~Pb}=36.7006$. Nd isotopes were corrected for fractionation to ${ }^{146} \mathrm{Nd} /{ }^{144} \mathrm{Nd}=0.7219$ and normalized to $\mathrm{La}$ Jolla value of 0.51184 . Sr values are normalized to NBS $987=0.710240$. Typical uncertainties for $\mathrm{Sr}$ and $\mathrm{Nd}$ are approximately $18 \mathrm{ppm}$. Uncertainties for $\mathrm{Pb}$ are $1,1.4$ and 1.6 per mil for ${ }^{206} \mathrm{~Pb} /{ }^{204} \mathrm{~Pb},{ }^{207} \mathrm{~Pb} /{ }^{204} \mathrm{~Pb},{ }^{208} \mathrm{~Pb} /{ }^{204} \mathrm{~Pb}$ respectively.

Table 2: Th and $U$ concentration determined by isotopic dilution and Th isotopes for Galapagos lavas. Ages determined by surface exposure dating techniques by Kurz. The Th isotopes have been corrected by the reported ages, assuming the ages represent the time of eruption. Parenthesis denote activity ratios; $\lambda_{230}=9.195 \times 10^{-6} \mathrm{yr}^{-1}, \lambda_{232}=4.948 \times 10^{-11} \mathrm{yr}^{-1}$, $\lambda_{238}=1.551 \times 10^{-10} \mathrm{yr}^{-1}$.

\subsection{Figure Caption}

Figure 1: Map of the Galapagos Archipelago. GSC is the Galapagos Spreading Center. The dash line represents the inferred fault from Feighner and Richards (1994). The fault separates thick $(12 \mathrm{~km}$ elastic thickness $)$, old $(\approx 10 \mathrm{Ma})$ and strong lithosphere to the west from a thin $(6 \mathrm{~km}$ elastic thickness), young $(\approx 5 \mathrm{Ma})$ and weak lithosphere to the east. The inset shows a regional view of the GSC.

Figure 2: a) Th isotope reproducibility for the UCSC standard measured by IMS 1270 ion probe. The TIMS value is reported for comparison. b) ICP-MS reproducibility for U isotope ratios for the NBS 960 standard measured, after correction for mass fractionation to the certified value of 137.88 .

Figure 3 : a) $\mathrm{SiO}_{2}$ versus $\mathrm{Na}_{2} \mathrm{O}+\mathrm{K}_{2} \mathrm{O}$ according to the classification of Le Bas et al., (1986). All of the samples plot in the field for basalts. Light dash-line separates the fields for alkaline and tholeiitic basalts (Macdonald and Katsura, 1964). Several samples (two

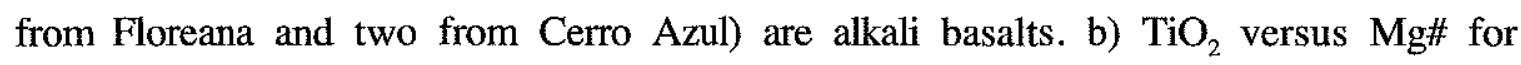
Galapagos lavas. Most of the lavas have undergone significant crystal fractionation. However, this differentiation did not reach saturation with ilmenite-magnetite in the analized samples. 
Figure 4 : a) Primitive mantle-normalized diagram for representative samples from the western (Fernandina and Darwin volcanoes) and eastern (Floreana and San Cristobal island) sector of the Galapagos Archipelago. $\mathrm{Nb}, \mathrm{Ti}, \mathrm{K}$ and $\mathrm{Y}$ anomalies are larger in lavas from the western volcanoes, while the $\mathrm{Sr}$ anomaly is larger in the lavas from the eastern islands. b) Primitive mantle-normalized REE. Note the flattening of the MREE to HREE in lavas from the eastern sector. Normalizing values are from Sun and McDonough,(1989), except for $\mathrm{Pb}$ and $\mathrm{Cs} 0.15$ and 0.021 respectively.

Figure 5 : a) $\mathrm{Sm}$ versus $\mathrm{Yb}$ contents (ppm). The lavas from the eastern islands have lower $\mathrm{Sm} / \mathrm{Yb}$ ratios than those from the western volcanoes. Note that the variation in $\mathrm{Sm} / \mathrm{Yb}$ ratios is mainly controlled by the variation in Sm content. The lines defines constant values of $\mathrm{Sm} / \mathrm{Yb}$ ratios $\mathrm{b})(\mathrm{La} / \mathrm{Yb})_{\mathrm{PM}}$ versus $(\mathrm{Sm} / \mathrm{Yb})_{\mathrm{PM}}$ ratios. Most of the lavas from the eastern islands have lower $(\mathrm{La} / \mathrm{Yb})_{\mathrm{PM}}$ and $(\mathrm{Sm} / \mathrm{Yb})_{\mathrm{PM}}$ ratios than those of the western volcanoes, with the exception of the Floreana lavas, which have similar $(\mathrm{La} / \mathrm{Yb})_{\mathrm{PM}}$ ratios to the lavas from the western volcanoes. Moreover, note that the Darwin and Wolf volcanoes have lavas with high $(\mathrm{Sm} / \mathrm{Yb})_{\mathrm{PM}}$ but low $(\mathrm{La} / \mathrm{Yb})_{\mathrm{PM}}$ ratios compared to the other western volcanoes. See text for explanation.The lines define values of constant $(\mathrm{La} / \mathrm{Sm})_{\mathrm{PM}}$ ratios.

Figure 6: $\mathrm{Ti} / \mathrm{Ti}^{*}=\left[2 \mathrm{Ti}_{\mathrm{PM}} /\left(\mathrm{Eu}_{\mathrm{PM}}+\mathrm{Gd}_{\mathrm{PM}}\right)\right]$ and $\mathrm{Y} / \mathrm{Y}^{*}=\left[2 \mathrm{Y}_{\mathrm{PM}} /\left(\mathrm{Dy}_{\mathrm{PM}}+\mathrm{Ho}_{\mathrm{PM}}\right)\right]$ versus $\mathrm{Hf} / \mathrm{Lu}$ ratios. With the exception of Floreana, the anomalies in Ti and $\mathrm{Y}$ tend to disappear in lavas from the eastern islands.

Figure 7: ${ }^{3} \mathrm{He} /{ }^{4} \mathrm{He}$ versus $\mathrm{K} / \mathrm{Rb}$ and $\mathrm{Ti} / \mathrm{Ti}{ }^{*}$. The correlation between the anomalies of $\mathrm{Ti}$ and $\mathrm{K}$ (we used $\mathrm{K} / \mathrm{Rb}$ as an approximation of $\mathrm{K} / \mathrm{K}^{*}$; see text) indicates that the mantle source responsible for the high ${ }^{3} \mathrm{He} /{ }^{4} \mathrm{He}$ is also responsible for the positive Ti and negative $\mathrm{K}$ anomalies.

Figure 8: ${ }^{143} \mathrm{Nd} /{ }^{144} \mathrm{Nd},{ }^{206} \mathrm{~Pb} /{ }^{204} \mathrm{~Pb}$ and ${ }^{87} \mathrm{Sr} /{ }^{86} \mathrm{Sr}$ versus $\mathrm{Nb} / \mathrm{Zr}$. $\mathrm{Nb} / \mathrm{Zr}$ correlates with isotopes, with the exception of the Floreana alkaline basalts for $\mathrm{Sr}$ and $\mathrm{Nd}$ isotope ratios, and one sample from San Cristobal that has anomalously high $\mathrm{Sr}$ isotopes. Although $\mathrm{Nb} / \mathrm{Zr}$ ratios do not correlate with $\mathrm{Sr}$ and $\mathrm{Nd}$ isotopes, they correlate with $\mathrm{Pb}$ isotopes suggesting that even in Floreana lavas, the trace element are in some way affected by mixing. The correlation between $\mathrm{Nb} / \mathrm{Zr}$ and isotopes indicates that the trace elements in Galapagos lavas are controlled mainly by source variations and mixing processes. Reference as in Figure 7 


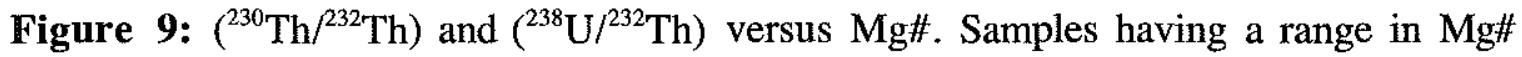
with similar $\mathrm{Sr}, \mathrm{Nd}$ and $\mathrm{Pb}$ isotopic composition have similar $\left({ }^{230} \mathrm{Th} /{ }^{232} \mathrm{Th}\right)$ and $\left({ }^{238} \mathrm{U} /{ }^{232} \mathrm{Th}\right)$ ratios; the best example of this is the suite of lavas from Cerro Azul volcano.

Figure 10: $\left({ }^{230} \mathrm{Th} /{ }^{232} \mathrm{Th}\right)$ versus $\left({ }^{238} \mathrm{U} /{ }^{232} \mathrm{Th}\right)$. a) Isochrone diagram for Galapagos lavas. Dashed lines are given for ${ }^{230} \mathrm{Th} /{ }^{238} \mathrm{U}$ ) ratios of $1.2,1.5$ and 2.0 ; the solid line is the equiline. The measured $\left.{ }^{230} \mathrm{Th} /{ }^{238} \mathrm{U}\right)$ ratios in all of the samples is much higher than 1 , indicating melting in the garnet stability field. $\left({ }^{230} \mathrm{Th} /{ }^{232} \mathrm{Th}\right)$ correlates roughly with ${ }^{238} \mathrm{U} /{ }^{232} \mathrm{Th}$ ), approaching the equiline as the $\left.{ }^{230} \mathrm{Th} /{ }^{232} \mathrm{Th}\right)$ ratio increases. The samples define two linear trends: one is well defined and contains most of the samples analyzed; the second trend is less well defined with samples from Floreana and San Cristobal. b) Comparison between the Galapagos lavas and a compilation of OIB and MORB data (C. Lundstrom, personal communication). Note that one extreme of the linear trend defined by the Galapagos samples (dashed line) overlaps with the field defined by MORB, especially with samples from the GSC and EPR $9^{\circ} \mathrm{N}$, which are geographically the closest MORB samples to the Archipelago. At the other end of the trend, the Galapagos samples show extreme disequilibrium, when compared to other OIB lavas, especially when compared with Hawaii. Analytical uncertainties for Galapagos samples are smaller than the symbols

Figure 11: $\mathrm{a}$ and b) $\left({ }^{230} \mathrm{Th} /{ }^{232} \mathrm{Th}\right)$ versus ${ }^{143} \mathrm{Nd} /{ }^{144} \mathrm{Nd}$ and $\mathrm{K} / \mathrm{Rb}$ ratios. The $\left({ }^{230} \mathrm{Th} /{ }^{232} \mathrm{Th}\right)$ correlates with $\mathrm{Sr} \mathrm{Nd}$ and $\mathrm{Pb}$ isotopes and with some trace element ratios, suggesting that source variations and mixing processes have also controlled the Th isotopic composition of Galapagos samples. c) $\left({ }^{230} \mathrm{Th} /{ }^{238} \mathrm{U}\right)$ versus $\mathrm{Ba} / \mathrm{Nb}$. This correlation is mainly defined by samples from Floreana and San Cristobal. Although $\mathrm{Ba} / \mathrm{La}, \mathrm{Ba} / \mathrm{Ce}$ and $\mathrm{Ba} / \mathrm{Nb}$ ratios correlate with $\left({ }^{230} \mathrm{Th} /{ }^{238} \mathrm{U}\right.$ ), these ratios also define positive trends with $\mathrm{Sr}$ and $\mathrm{Pb}$ isotope ratios, suggesting that the variation in the ratios is produced mainly by source variation and mixing. References as in Figure 10

Figure 12: $\mathrm{Nb} / \mathrm{La}$ versus $\mathrm{Nb} / \mathrm{Zr}$ ratios. With the exception of two alkali basalts from Floreana, the Galapagos lavas define a steep trend. Dashed-lines represent results of nonmodal batch melting models in the garnet and the spinel stability field, the number next to the (+) symbols represents the extent of melting in \%. We assumed an enriched source that melts in the garnet stability field, from an initial $\mathrm{Nb} / \mathrm{La}=1.3, \mathrm{Nb} / \mathrm{Zr}=0.07$. Note that the $\mathrm{Nb} / \mathrm{La}$ and $\mathrm{Nb} / \mathrm{Zr}$ ratios are slightly more enriched than the $\mathrm{PM} \approx 1.02$ and 0.063 respectively, because we assumed a source with a positive anomaly in $\mathrm{Nb}$. We assumed a 
depleted MORB source with $\mathrm{Nb} / \mathrm{La}=0.6$ and $\mathrm{Nb} / \mathrm{Zr}=0.03$, with melting in the spinel stability field. The mineral mode for the enriched garnet source is taken from Beattie (1993), and the melting reaction is from Walter (1998), for $3 \mathrm{GPa}$. For the depleted source we used the mineral mode and melting reaction from Kinzler and Grove (1992). Most of the Galapagos lavas plot in the area defined by mixing between lavas representing a low extent of melting from an enriched source (in the presence of garnet) and a moderate extent of melting from a depleted source (in the spinel field). The partition coefficients are from a compilation made by Takazawa (1996) for La and $\mathrm{Zr}$, and from Kelemen et al. (1993), for $\mathrm{Nb}$. Note that the alkaline basalts from Floreana seem to reproduce melting along a trend comparable to the garnet trend. This would suggest that melting processes in Floreana basalts seem to have displaced some of the incompatible trace elements ratios (such as $\mathrm{Nb} / \mathrm{La}$ and $\mathrm{Nb} / \mathrm{Zr}$ ) away from the overal mixing trend.

Figure 13: Primitive mantle-normalized REE for Floreana and San Cristobal lavas. In both cases, the flat MREE to HREE patterns can be explained by mixing between magmas produced by a low extent of melting from an enriched garnet source and melts produced by moderate extent of melting from a depleted spinel source. In both cases the pattern for the mixture is shown by thick gray lines. a) Floreana lavas are reproduced by a 7.3:1 mixture of $5 \%$ melt from a $5 \%$ previously depleted primitive spinel mantle and a $0.1 \%$ melt from primitive garnet mantle. b) San Cristobal lavas are reproduced by a mixture $1: 32$ of $0.5 \%$ melt from primitive garnet mantle and $7 \%$ melt from a $5 \%$ previously depleted spinel primitive mantle. We used the source mineralogy and melting reaction of Kinzler and Grove (1992) for the spinel mantle, and the source mineralogy from Beattie (1993) and the $3 \mathrm{GPa}$ melting reaction of Walter (1998) for the garnet source. The initial composition is the primitive mantle of Sun and McDonough (1989). Partition coefficients are from a compilation made by Takazawa (1996). These models are not unique solutions and many other combinations can explain the data. The main goal of the modeling is to demonstrate that flat MREE to HREE patterns are not necessarily an indication of melting in the spinel stability field. Rather, lavas with flat REE patterns can carry a garnet signature in the highly incompatible elements, as in the case of $\mathrm{Th} / \mathrm{U}$ fractionation (see Figure 10).

Figure 14: Mantle upwelling velocities versus mantle porosities. These figures show contours of constant $\left({ }^{230} \mathrm{Th} /{ }^{238} \mathrm{U}\right)$. We choose the maximum ${ }^{230} \mathrm{Th}$ excess observed in each volcano/island analyzed from Galapagos, such that each contour represent one volcano. The figure shows the results of dynamic melting processes (McKenzie, 1985) applying two 
different sets of partition coefficients (Beattie, 1993; LaTourrette et al., 1993). In dynamic melting, Th and $U$ are readily stripped from the mantle solid, therefore the extent of melting does not play an important role in the extent of disequilibrium. Using LaTourrettte's $\mathrm{D}_{U}$ and $\mathrm{D}_{\mathrm{Th}}$ will require smaller mantle porosities and upwelling rates than those obtained using Beattie's D.

Figure 15: Mantle upwelling velocities versus mantle porosities for equilibrium porous flow. As before, we used the same two sets of partition coefficients. We also considered four different melt column lengths: $1.7 \mathrm{~km}(\approx 0.5 \%$ melting $), 3 \mathrm{~km}(\approx 1 \%$ melting $), 17 \mathrm{~km}$ $(\approx 5 \%$ melting $)$ and $33 \mathrm{~km}(\approx 10 \%$ melting), assuming a constant melt productivity of $\approx$ $0.3 \% / \mathrm{km}$. In these models we have used the analytical solution of Sims et al., (1999), which considers a constant porosity as an approximation to the numerical solution. As shown by Sims et al. (1999) for Th-U disequilibrium, the analytical solution gives comparable results to the numerical solution. The model assumes modal melting, the source mineral composition taken from Beattie, (1993) and melting in the garnet field. As in dynamic melting, LaTourrette's D's require slower mantle upwelling rates and porosities than Beattie's D's, especially for the case of very high ${ }^{230} \mathrm{Th}$ excesses. Note that the differences between the models generated by using both sets of partition coefficients is larger at a low extent of melting $(\mathrm{F} \approx \mathrm{D})$, where melting processes play a more important role in the extent of Th-U disequilibrium. As $F$ increases $(F>D)$, the transport processes control the extent of disequilibrium. Thus, porosity and length of the columns begin to be major factors in affecting the ${ }^{230} \mathrm{Th}$ excesses, decreasing the effect of using different Ds. 
TABLE 1

\begin{tabular}{|c|c|c|c|c|c|c|c|c|}
\hline $\begin{array}{c}\text { Sample ID } \\
\text { island/volcano }\end{array}$ & $\begin{array}{l}\text { NSK97-202 } \\
\text { Fernandina }\end{array}$ & $\begin{array}{l}\text { NSK97-206 } \\
\text { Fernandina }\end{array}$ & $\begin{array}{c}\text { NSK97-214 } \\
\text { Fernandina } \\
\end{array}$ & $\begin{array}{l}\text { NSK97-215 } \\
\text { Fernandina }\end{array}$ & $\begin{array}{c}\text { NSK97-216 } \\
\text { Fernandina }\end{array}$ & $\begin{array}{l}\text { NSK97-224 } \\
\text { Fernandina }\end{array}$ & $\begin{array}{l}\text { NSK97-228 } \\
\text { Fernandina }\end{array}$ & $\begin{array}{l}\text { SG 93-16 } \\
\text { Fernandina }\end{array}$ \\
\hline $\mathrm{SHO} 2$ & 49.39 & 49.61 & 49.44 & 48.5 & 48.88 & 49.18 & 48.9 & 49.38 \\
\hline $\mathrm{Al} 2 \mathrm{O} 3$ & 15.87 & 15.52 & 14.77 & 13.98 & 15.05 & 15.71 & 16.08 & 15.59 \\
\hline $\mathrm{TiO} 2$ & 2.5 & 2.58 & 3.12 & 2.72 & 3.42 & 3.09 & 3.13 & 2.72 \\
\hline $\mathrm{FeO}$ & 9.66 & 9.83 & 11.3 & 10.42 & 11.46 & 10.22 & 10.72 & 10.45 \\
\hline $\mathrm{MnO}$ & 0.17 & 0.17 & 0.19 & 0.17 & 0.19 & 0.18 & 0.18 & 0.18 \\
\hline $\mathrm{MgO}$ & 7.63 & 7.5 & 6.41 & 10.4 & 5.84 & 6.21 & 5.81 & 6.52 \\
\hline $\mathrm{CaO}$ & 11.88 & 11.89 & 11.6 & 10.68 & 11.34 & 11.75 & 11.45 & 12.09 \\
\hline K2O & 0.31 & 0.32 & 0.39 & 0.36 & 0.54 & 0.47 & 0.48 & 0.38 \\
\hline $\mathrm{Na} 2 \mathrm{O}$ & 2.36 & 2.34 & 2.46 & 2,49 & 2.91 & 2.86 & 2.92 & 2.5 \\
\hline P2O5 & 0.25 & 0.25 & 0.31 & 0.27 & 0.38 & 0.34 & 0.34 & 0.27 \\
\hline Total & 100 & 100 & 100 & 100 & 100 & 100 & 100 & 100 \\
\hline \multicolumn{9}{|l|}{ XFF } \\
\hline $\mathrm{NI}$ & 97 & B 7 & 49 & 225 & 37 & 51 & 37 & 58 \\
\hline $\mathrm{Cr}$ & 323 & 288 & 155 & 641 & 143 & 186 & 185 & 193 \\
\hline $\mathrm{Sc}$ & 35 & 34 & 33 & 35 & 35 & 35 & 30 & 38 \\
\hline V & 309 & 316 & 366 & 331 & 383 & 357 & 351 & 330 \\
\hline $\mathrm{Ba}$ & 35 & 37 & 37 & 34 & 41 & 58 & 29 & 40 \\
\hline $\mathrm{Rb}$ & 6 & 6 & 6 & 8 & 9 & 10 & 5 & 6 \\
\hline $\mathrm{Sr}$ & 311 & 304 & 321 & 303 & 350. & 344 & 354 & 330 \\
\hline $\mathrm{Zr}$ & 126 & 128 & 155 & 135 & $196^{\circ}$ & 171 & 172 & 146 \\
\hline$Y$ & 23 & 23 & 29 & 23 & 31 & 29 & 29 & 25 \\
\hline $\mathrm{Nb}$ & $\$ 7.4$ & 17.3 & 21.0 & 19.1 & 26.0 & 23.8 & 22.3 & 19.3 \\
\hline $\mathrm{Ga}$ & 22 & 22 & 26 & 22 & 23 & 27 & 25 & 25 \\
\hline $\mathrm{Cu}$ & 80 & 75 & 83 & 63 & 87 & 78 & 72 & 94 \\
\hline $\mathrm{Zn}$ & 101 & 96 & 110 & 104 & 110 & 106 & 107 & 97 \\
\hline \multicolumn{9}{|l|}{ ICPMS } \\
\hline $\mathrm{Cs}$ & 0.06 & 0.06 & 0.07 & 0.06 & 0.08 & 0.09 & 0.08 & 0.07 \\
\hline $\mathrm{Rb}$ & 5.4 & 5.3 & 7.6 & 6.0 & 9.7 & B.2 & 8.6 & 6.2 \\
\hline $\mathrm{Ba}$ & 68 & 67 & 89 & 73 & 114 & 99 & 101 & 80 \\
\hline Th & 0.97 & 0.94 & 1.31 & 1.05 & 1.64 & 1.35 & 1.36 & 1.14 \\
\hline $\mathrm{U}$ & 0.28 & 0.27 & 0.38 & 0.3 & 0.49 & 0.39 & 0.4 & 0.34 \\
\hline $\mathrm{Nb}$ & 15.2 & 15.1 & 20.0 & 16.9 & 24.3 & 21.5 & 21.6 & 17.1 \\
\hline $\mathrm{Ta}$ & 1.08 & 1.08 & 1.5 & 1.24 & 1.75 & 1.51 & 1.59 & 1.23 \\
\hline $\mathrm{La}$ & 10.5 & 10.4 & 14.1 & 11.8 & 17.9 & 15.7 & 15.5 & 12.9 \\
\hline $\mathrm{Ce}$ & 24.3 & 24.0 & 32.3 & 27.0 & 40.2 & 35.4 & 34.8 & 28.1 \\
\hline $\mathrm{Pb}$ & 1.42 & 1.16 & 0.93 & 1.15 & 1.1 & 3.21 & 0.96 & 1.18 \\
\hline $\mathrm{Pr}$ & 3.22 & 3.24 & 4.23 & 3.66 & 5.27 & 4.72 & 4.65 & 3.79 \\
\hline $\mathrm{Sr}$ & 305 & 301 & 351 & 289 & 371 & 360 & 383 & 323 \\
\hline $\mathrm{Nod}$ & 15.6 & 15.2 & 19.5 & 17.1 & 23.9 & 21.6 & 21.5 & 17.7 \\
\hline $\mathrm{Sm}$ & 4.50 & 4.48 & 5.77 & 4.88 & 6.92 & 6.26 & 6.13 & 5.02 \\
\hline $\mathrm{Hf}$ & 3.06 & 3.12 & 4.15 & 3.35 & 4.96 & 4.34 & 4.5 & 3.59 \\
\hline Eu & 1.60 & 1.61 & 2.04 & 1.78 & 2.37 & 2.10 & 2.18 & 1.84 \\
\hline Gd & 4.74 & 4.69 & 6.01 & 5.09 & 7.04 & 6.32 & 6.50 & 5.32 \\
\hline $\mathrm{Tb}$ & 0.80 & 0.79 & 1.03 & 0.87 & 1.17 & 1.07 & 1.09 & 0.92 \\
\hline Dy & 4.69 & 4.76 & 6.08 & 5.13 & 6.94 & 6.30 & 6.40 & 5.47 \\
\hline$Y$ & 23.9 & 24.1 & 30.1 & 24.3 & 34.5 & 31.6 & 32.1 & 26.8 \\
\hline $\mathrm{Ho}$ & 0.93 & 0.93 & 1.21 & 0.99 & 1.37 & 1.21 & 1.25 & 1.04 \\
\hline $\mathrm{Er}$ & 2.27 & 2.35 & 3.04 & 2.46 & 3.42 & 3.10 & 3.21 & 2.59 \\
\hline $\mathrm{Tm}$ & 0.31 & 0.33 & 0.41 & 0.34 & 0.47 & 0.43 & 0.44 & 0.36 \\
\hline$y_{b}$ & 1.82 & 1.85 & 2.46 & 2.00 & 2.80 & 2.48 & 2.57 & 2.07 \\
\hline Lu & 0.27 & 0.28 & 0.36 & 0.29 & 0.41 & 0.37 & 0.38 & 0.31 \\
\hline $\mathrm{Sc}$ & 35.6 & 35.5 & 44.3 & 33.6 & 42.2 & 40.0 & 39.1 & 38.7 \\
\hline $3 \mathrm{He} / 4 \mathrm{He}$ & 25 & 23 & 30 & 22 & 22 & 23 & 25 & 27 \\
\hline $87 \mathrm{Sr} / 86 \mathrm{Sr}$ & 0.703272 & 0.703304 & 0.70329 & 0.703264 & 0.703251 & 0.703249 & 0.703207 & 0.703234 \\
\hline $143 \mathrm{Nd} / 144 \mathrm{Nd}$ & 0.512921 & 0.512929 & 0.512937 & 0.512922 & 0.512958 & 0.51294 & 0.512947 & 0.512965 \\
\hline $206 \mathrm{~Pb} / 204 \mathrm{~Pb}$ & & & & & & & & \\
\hline $207 \mathrm{~Pb} / 204 \mathrm{~Pb}$ & & & & & & & & \\
\hline $208 \mathrm{~Pb} / 204 \mathrm{~Pb}$ & & & & & & & & \\
\hline
\end{tabular}


TABLE 1

\begin{tabular}{|c|c|c|c|c|c|c|c|c|}
\hline $\begin{array}{c}\text { Sample ID } \\
\text { island/volcano }\end{array}$ & $\begin{array}{c}\text { NSK97-238 } \\
\text { Santiago }\end{array}$ & $\begin{array}{c}\text { NSK97-252 } \\
\text { San Cristobal }\end{array}$ & $\begin{array}{c}\text { NSK97-254 } \\
\text { San Cristobal }\end{array}$ & $\begin{array}{l}\text { SG93-22 } \\
\text { Floreana }\end{array}$ & $\begin{array}{c}\text { SG 93-5 } \\
\text { Cerro Azul }\end{array}$ & $\begin{array}{c}\text { SG 93-7 } \\
\text { Cerro Azul }\end{array}$ & $\begin{array}{c}\text { SG 93-8 } \\
\text { Cerro Azul }\end{array}$ & $\begin{array}{l}\text { SG 93-12 } \\
\text { Cerro Azui }\end{array}$ \\
\hline $\mathrm{SiO} 2$ & 48.4 & 47.3 & 47.44 & 46.4 & 48.09 & 50.93 & 48.89 & 49.08 \\
\hline $\mathrm{Al} 2 \mathrm{O} 3$ & 14.85 & 16.77 & 16.4 & 14.39 & 14.79 & 13.6 & 15.49 & 14.34 \\
\hline $\mathrm{TiO} 2$ & 2.13 & 1.01 & 0.98 & 1.67 & 2.04 & 1.45 & 2.66 & 3,4 \\
\hline $\mathrm{FeO}$ & 10.67 & 8.83 & 9.04 & 9.78 & 9.96 & 9.47 & 10.22 & 12.37 \\
\hline MnO & 0.18 & 0.16 & 0.17 & 0.17 & 0.18 & 0.16 & 0.19 & 0.22 \\
\hline $\mathrm{MgO}$ & 10.22 & 11.17 & 11.8 & 13.3 & 10.2 & 11.84 & 7.03 & 5.72 \\
\hline $\mathrm{CaO}$ & 10.25 & 12.37 & 11.55 & 10.6 & 11.75 & 9.9 & 11.28 & 10.24 \\
\hline $\mathrm{K} 2 \mathrm{O}$ & 0.31 & 0.12 & 0.19 & 0.83 & 0.34 & 0.18 & 0.66 & 0.78 \\
\hline $\mathrm{Na} 2 \mathrm{O}$ & 2.74 & 2.16 & 2.31 & 2.66 & 2.45 & 2.34 & 3.23 & 3.44 \\
\hline $\mathrm{P} 2 \mathrm{O} 5$ & 0.24 & 0.1 & 0.11 & 0.22 & 0.21 & 0.14 & 0.35 & 0.42 \\
\hline Total & 100 & 100 & 100 & 100 & 100 & 100 & 100 & 100 \\
\hline \multicolumn{9}{|l|}{ XPF } \\
\hline $\mathrm{Ni}$ & 241 & $2 \nmid 1$ & 259 & 324 & 201 & 356 & 97 & 46 \\
\hline $\mathrm{Cr}$ & 495 & 481 & 479 & 698 & 508 & 583 & 227 & 90 \\
\hline Sc & 34 & 40 & 40 & 33 & 37 & 30 & 35 & 34 \\
\hline V & 246 & 228 & 210 & 247 & 288 & 189 & 326 & 412 \\
\hline $\mathrm{Ba}$ & 27 & 28 & 44 & 257 & 77 & 38 & 107 & 138 \\
\hline $\mathrm{Rb}$ & 5 & 3 & 3 & 20 & 6 & 5 & 13 & 15 \\
\hline $\mathrm{Sr}$ & 234 & 173 & 173 & 390 & 284 & 182 & 358 & 356 \\
\hline $\mathrm{Zr}$ & 139 & 66 & 67 & 91 & 113 & 77 & 178 & 211 \\
\hline$Y$ & 29 & 21 & 21 & 21 & 22 & 17 & 29 & 35 \\
\hline $\mathrm{Nb}$ & 11.1 & 5.2 & 6.5 & 23.5 & 17.8 & 9.1 & 28.8 & 36.4 \\
\hline $\mathrm{Ga}$ & 21 & 15 & 16 & 13 & 19 & 17 & 21 & 24 \\
\hline $\mathrm{Cu}$ & 80 & 281 & 330 & 76 & 68 & 77 & 74 & 71 \\
\hline $\mathrm{Zn}$ & 92 & 58 & 60 & 68 & 85 & 80 & 97 & 118 \\
\hline \multicolumn{9}{|l|}{ ICPMS } \\
\hline Cs & 0.05 & 0.02 & 0.04 & 0.23 & 0.06 & 0.04 & 0.13 & 0.18 \\
\hline $\mathrm{Ab}$ & 5.1 & 1.2 & 2.3 & 19.4 & 6.1 & 3.6 & 12.5 & 14.9 \\
\hline $\mathrm{Ba}$ & 49 & 24 & 38 & 279 & 88 & 44 & 148 & 188 \\
\hline Th & 0.76 & 0.24 & 0.37 & 1.3 & 1.08 & 0.57 & 1.99 & 2.35 \\
\hline $\mathrm{U}$ & 0.21 & 0.06 & 0.1 & 0.22 & 0.29 & 0.16 & 0.54 & 0.64 \\
\hline $\mathrm{Nb}$ & 9.6 & 3.6 & 4.9 & 22.2 & 15.5 & 7.7 & 27.6 & 33.9 \\
\hline Ta & 0.65 & 0.25 & 0.31 & 1.22 & 1.01 & 0.52 & 1.79 & 2.19 \\
\hline $\mathrm{La}$ & 9.0 & 3.4 & 4.3 & 16.0 & 12.0 & 5.8 & 20.8 & 25.0 \\
\hline $\mathrm{Ce}$ & 21.0 & 8.5 & 9.5 & 26.6 & 26.1 & 12.9 & 43.2 & 51.6 \\
\hline $\mathrm{Pb}$ & 1.07 & 0.9 & 0.75 & 2.99 & 1.1 & 0.99 & 1.89 & 2.27 \\
\hline $\mathrm{Pr}$ & 2.99 & 1.31 & 1.36 & 3.04 & 3.4 & 1.82 & 5.61 & 6.55 \\
\hline $\mathrm{Sr}$ & 230 & 174 & 167 & 390 & $2 B 3$ & 187 & 378 & 362 \\
\hline Nd & 14.9 & 6.8 & 6.6 & 12.5 & 15.5 & B. 9 & 24.9 & 28.9 \\
\hline $\mathrm{Sm}$ & 4.90 & 2.40 & 2.18 & 3.24 & 4.42 & 3.05 & 6.53 & 7.74 \\
\hline $\mathrm{Hf}$ & 3.53 & 1.65 & 1.54 & 1.8 & 2.97 & 2.1 & 4.6 & 5.45 \\
\hline $\mathrm{Eu}$ & 1.79 & 0.96 & 0.89 & 1.18 & 1.56 & 1.13 & 2.22 & 2.59 \\
\hline $\mathrm{Gd}$ & 5.61 & 3.16 & 2.84 & 3.50 & 4.73 & 3.60 & 6.68 & 7.71 \\
\hline $\mathrm{Tb}$ & 0.94 & 0.61 & 0.55 & 0.64 & 0.80 & 0.64 & 1.08 & $\{.27$ \\
\hline Dy & 5.86 & 4.08 & 3.87 & 4.03 & 4.88 & 3.77 & 6.56 & 7.77 \\
\hline$Y$ & 29.2 & 23.0 & 22.1 & 21.9 & 23.3 & 19.7 & 32,4 & 37.1 \\
\hline Ho & 1.12 & 0.89 & 0.83 & 0.82 & 0.95 & 0.75 & 1.26 & 1.48 \\
\hline Er & 2.93 & 2.56 & 2.37 & 2.34 & 2.40 & 1.93 & 3.20 & 3.74 \\
\hline $\mathrm{Tm}$ & 0.39 & 0.37 & 0.34 & 0.32 & 0.34 & 0.26 & 0.44 & 0.51 \\
\hline $\mathrm{Yb}$ & 2.37 & 2.36 & 2.32 & 1.96 & 1.96 & 1.55 & 2.63 & 3.00 \\
\hline Lu & 0.35 & 0.37 & 0.36 & 0.32 & 0.30 & 0.23 & 0.39 & 0.45 \\
\hline $\mathrm{Sc}$ & 32.4 & 45.4 & 41.6 & & 36.77 & 31.74 & 36.73 & 34.86 \\
\hline $3 \mathrm{He} / 4 \mathrm{He}$ & 9 & B & 10 & 14 & 14 & 14 & 14 & 12 \\
\hline $875 r / B 6 S r$ & 0.703036 & 0.702991 & 0.703485 & 0.703415 & 0.703323 & 0.703366 & 0.703288 & 0.703344 \\
\hline $143 \mathrm{Nd} / 144 \mathrm{Nd}$ & 0.512998 & 0.513041 & 0.513042 & 0.512946 & & $0.51295 \mathrm{~B}$ & 0.512929 & 0.512917 \\
\hline $206 \mathrm{~Pb} / 204 \mathrm{~Pb}$ & & & & 19.783 & & & & \\
\hline $207 \mathrm{~Pb} / 204 \mathrm{~Pb}$ & & & & 15.619 & & & & \\
\hline $208 \mathrm{~Pb} / 204 \mathrm{~Pb}$ & & & & 39.515 & & & & \\
\hline
\end{tabular}


TABLE 1

\begin{tabular}{|c|c|c|c|c|c|}
\hline $\begin{array}{c}\text { Sample ID } \\
\text { island/volcano }\end{array}$ & $\begin{array}{c}\text { Gi92-5 } \\
\text { Sierra Negra } \\
\end{array}$ & $\begin{array}{c}\text { G192-8 } \\
\text { Sierra Negra } \\
\end{array}$ & $\begin{array}{l}\text { Gl92-17 } \\
\text { Darwin } \\
\end{array}$ & $\begin{array}{l}\text { Gige-18 } \\
\text { Darwin }\end{array}$ & $\begin{array}{l}\text { Gl92-19 } \\
\text { Ecuador }\end{array}$ \\
\hline $\mathrm{SiO} 2$ & 49.33 & 49.06 & 48.98 & 48.8 & 47.93 \\
\hline $\mathrm{Al} 2 \mathrm{O} 3$ & 13.97 & 14.18 & 16.61 & 16.74 & 14.32 \\
\hline $\mathrm{TiO} 2$ & 3.01 & 3.36 & 2.79 & 2.58 & 2.29 \\
\hline $\mathrm{FeO}$ & 12.2 & 12.71 & 10.37 & 10.05 & 11 \\
\hline $\mathrm{MnO}$ & 0.19 & 0.21 & 0.17 & 0.16 & 0.17 \\
\hline $\mathrm{MgO}$ & 6.5 & 5.99 & 5.65 & 6.07 & 10.9 \\
\hline $\mathrm{CaO}$ & 11.19 & 10.62 & 11.88 & 12.39 & 9.9 \\
\hline $\mathrm{K} 2 \mathrm{O}$ & 0.44 & 0.49 & 0.39 & 0.32 & 0.52 \\
\hline $\mathrm{Na} 2 \mathrm{O}$ & 2.86 & 3.03 & 2.89 & 2.64 & 2.69 \\
\hline $\mathrm{P} 2 \mathrm{O} 5$ & 0.29 & 0.34 & 0.27 & 0.24 & $0.2 B$ \\
\hline Total & 100 & 100 & 99.99 & 100 & 100 \\
\hline \multicolumn{6}{|l|}{ XFF } \\
\hline $\mathrm{Ni}$ & 53 & 40 & 53 & 56 & 265 \\
\hline $\mathrm{Cr}$ & 158 & 104 & 99 & 152 & 499 \\
\hline So & 40 & 36 & 34 & 35 & 27 \\
\hline$v$ & 367 & 362 & 331 & 309 & 226 \\
\hline $\mathrm{Ba}$ & 63 & 92 & 22 & 24 & 95 \\
\hline $\mathrm{Rb}$ & 8 & 9 & 6 & 3 & 10 \\
\hline $\mathrm{Sr}$ & 296 & 302 & 374 & 382 & 344 \\
\hline $\mathrm{Zr}$ & 160 & 183 & 166 & 155 & 150 \\
\hline$Y$ & 32 & 35 & 27 & 26 & 25 \\
\hline $\mathrm{Nb}$ & 25.3 & 28.5 & 14.5 & 12.8 & 22.1 \\
\hline $\mathrm{Ga}$ & 24 & 24 & 26 & 23 & 19 \\
\hline $\mathrm{Cu}$ & 105 & 92 & 120 & 125 & 68 \\
\hline $\mathrm{Zn}$ & 110 & 117 & 89 & 82 & 94 \\
\hline \multicolumn{6}{|l|}{ ICPMS } \\
\hline $\mathrm{Cs}$ & 0.08 & 0.1 & 0.05 & 0.06 & 0.11 \\
\hline $\mathrm{Ab}$ & 7.5 & 8.7 & 4.7 & 3.6 & 9.2 \\
\hline $\mathrm{Ba}$ & 97 & 115 & 51 & 44 & 120 \\
\hline Th & 1.13 & 1.39 & 0.78 & 0.66 & 1.27 \\
\hline $\mathrm{u}$ & 0.25 & 0.36 & 0.2 & 0.18 & 0.28 \\
\hline $\mathrm{Nb}$ & 23.3 & 26.8 & 13.4 & 11.9 & 20.5 \\
\hline $\mathrm{Ta}$ & 1.5 & 1.75 & 0.91 & 0.8 & 1.2 \\
\hline $\mathrm{La}$ & 15.6 & 17,9 & 13.0 & 11.5 & 15.7 \\
\hline $\mathrm{Co}$ & 34.3 & 39.4 & 30.1 & 26.8 & 32.3 \\
\hline $\mathrm{Pb}$ & 0.98 & 1.38 & 2.49 & 2.27 & 1.68 \\
\hline $\mathrm{Pr}$ & 4.68 & 5.31 & 4.1 & 3.68 & 4.09 \\
\hline $\mathrm{Sr}$ & 296 & 302 & 374 & 382 & 344 \\
\hline $\mathrm{Nd}$ & 21.4 & 24.5 & 19.0 & 17.4 & 18.8 \\
\hline $\mathrm{Sm}$ & 6.19 & 6.99 & 5.78 & 5.20 & 5.23 \\
\hline$H F$ & 3.94 & 4.53 & 3.61 & 3.36 & 3.36 \\
\hline $\mathrm{Eu}$ & 2.21 & 2.46 & 2.06 & 1.89 & 1.81 \\
\hline Gd & 6.12 & 6.95 & 5.75 & 5.36 & 5.22 \\
\hline $\mathrm{Tb}$ & 1.10 & 1.24 & 0.98 & 0.89 & 0.89 \\
\hline Dy & 6.56 & 7.25 & 5.81 & 5.29 & 5.12 \\
\hline$Y$ & 31.7 & 35.7 & 27.8 & 25.4 & 26.0 \\
\hline Ho & 1.28 & 1.40 & 1.14 & 1.01 & 0.99 \\
\hline Er & 3.35 & 3.75 & 2.95 & 2.70 & 2.67 \\
\hline $\mathrm{Tm}$ & 0.43 & 0.50 & 0.39 & 0.35 & 0.35 \\
\hline $\mathrm{Yb}$ & 2.59 & 2.91 & 2.25 & 2.01 & 2.04 \\
\hline $\begin{array}{l}\mathrm{Lu} \\
\mathrm{Sc}\end{array}$ & 0.39 & 0.44 & 0.33 & 0.29 & 0.30 \\
\hline $3 \mathrm{He} / 4 \mathrm{He}$ & 16 & 17 & 12 & 12 & 10 \\
\hline $875 r / 865 r$ & 0.703365 & 0.703504 & 0.702898 & 0.702856 & 0.7032 \\
\hline $143 \mathrm{Nd} / 144 \mathrm{Nd}$ & 0.512904 & 0.512941 & 0.513011 & 0.51302 & 0.512951 \\
\hline $206 \mathrm{~Pb} / 204 \mathrm{~Pb}$ & 19,342 & & 18.797 & 18.78 & 19.294 \\
\hline $207 \mathrm{~Pb} / 204 \mathrm{~Pb}$ & 15.569 & & 15.518 & $\$ 5.512$ & 15.575 \\
\hline $208 \mathrm{~Pb} / 204 \mathrm{~Pb}$ & 38.989 & & 38.296 & 38.26 & 38.968 \\
\hline
\end{tabular}


TABLE 2

\begin{tabular}{|c|c|c|c|c|c|c|c|c|c|c|c|c|}
\hline Sample ID & island/volcano & Th ppm (ID) & U ppm (DD) & $(2384 / 232 T h)$ & (230Th/232Th) & 2St err \% & (230Th/238U) & age (Ka) & $(230 \mathrm{Th} / 232 \mathrm{Th})$ & age & $(230 \mathrm{Th} / 238 \mathrm{U})$ & age \\
\hline NSK97-202 & Fernandina & 0.95 & 0.25 & 0.812 & 1.063 & 1.03 & 1.310 & $1.87 \pm 0.4$ & 1.067 & & 1.315 & \\
\hline NSK97-206 & Fernandina & 0.97 & 0.26 & 0.816 & 1.055 & 0.90 & 1.292 & $3 \pm 0.3$ & 1.061 & & 1.300 & \\
\hline NSK97-214 & Fernandina & 1.16 & 0.31 & 0.821 & 1.035 & 0.53 & 1.261 & $>0.9$ & 1.037 & & 1.263 & \\
\hline NSK $97-215$ & Femandina & 1.20 & 0.32 & 0.801 & 1.012 & 0.50 & 1.264 & $<0.1$ & 1.012 & & 1.265 & \\
\hline NSK97-216 & Fernandina & 1.54 & 0.42 & 0.822 & 1.072 & 0.80 & 1.303 & historical (1982) & 1.072 & & 1.303 & \\
\hline NSK97-224 & Fernandina & 1.39 & 0.38 & 0.824 & 1.034 & 0.45 & 1.256 & historical (3995) & 1.034 & & 1.256 & \\
\hline NSK97-224R & Fernandina & 1.39 & 0.38 & 0.824 & 1.045 & 0.74 & 1.269 & historical (1995) & 1.045 & & 1.268 & \\
\hline NSK97-228 & Fernandina & 1.42 & 0.38 & 0.819 & 1.047 & 0.77 & 1.278 & $<0.6$ & 1.048 & & 1.279 & \\
\hline SG $93-16$ & Fernandina & 1.13 & 0.31 & 0.830 & 1.067 & 0.66 & 1.287 & $1 \pm 0.6$ & 1.070 & & 1.289 & \\
\hline NSK97-238 & Santiago & 0.75 & 0.20 & 0.811 & 1.040 & 0.64 & 1.284 & $<0.9$ & 1.042 & & 1.286 & \\
\hline NSK97-126 & San Cristobal & 0.64 & 0.16 & 0.765 & 1.100 & 0.90 & 1.438 & $9.2 \pm 0.7$ & 1.130 & & 1.477 & \\
\hline NSK97-252 & San Cristobal & 0.24 & 0.07 & 0.833 & 1.132 & 0.96 & 1.359 & $15 \pm 1$ & 1.177 & & 1.412 & \\
\hline NSK97-254 & San Cristobal & 0.37 & 0.10 & 0.821 & 1.087 & 1.05 & 1.325 & $13 \pm 0.5$ & 1.121 & & 1.366 & \\
\hline SG93-22 & Floreana & 1.52 & 0.29 & 0.574 & 0.938 & 0.60 & 1.635 & $26 \pm 7$ & 1.036 & & 1.806 & \\
\hline SG 93-5 & Cerro AzuI & 1.06 & 0.27 & 0.759 & 1.040 & 0.58 & 1.371 & $<1$ & 1.043 & & 1.374 & \\
\hline SG 93-7 & Cerro Azul & 0.50 & 0.14 & 0.843 & 1.042 & 1.12 & 1.236 & $9 \pm 4$ & 1.045 & & 1.240 & \\
\hline SG 93-8 & Cerro Azul & $t .99$ & 0.51 & 0.772 & 1.043 & 0.57 & 1.351 & $<0.8$ & 1.045 & & 1.353 & \\
\hline SG $93-12$ & Cerro Azul & 2.32 & 0.58 & 0.757 & 1.027 & 0.58 & 1.357 & $1.7 \pm 0.3$ & 1.032 & & 1.363 & \\
\hline G192-5 & Sierra Negra & 1.31 & 0.34 & 0.786 & 1.010 & 0.82 & 1.285 & $0.6 \pm 0.4$ & 1.011 & & 1.287 & \\
\hline GI92-8 & Sierra Negra & 1.61 & 0.47 & 0.884 & 1.027 & 0.69 & 1.163 & $0.9 \pm 0.4$ & 1.028 & & 1.164 & \\
\hline SN 91-60 & Sierra Negra & 1.63 & 0.43 & 0.798 & 1.030 & 0.46 & 1.291 & $1.6 \pm 1$ & 1.034 & & 1.295 & \\
\hline Gl92-17 & Darwin & 0.91 & 0.27 & 0.905 & 1.120 & 0.97 & 1,238 & $0.8 \pm 0.3$ & 1.122 & & 1.240 & \\
\hline G192-18 & Darwin & 0.70 & 0.21 & 0.907 & 1.140 & 0.78 & 1.257 & $1.7 \pm 0.4$ & 1.144 & & 1.261 & \\
\hline Gl92-19 & Ecuador & 1.44 & 0.36 & 0.761 & 1.053 & 0.74 & 1.384 & $<0.8$ & 1.055 & & 1.387 & \\
\hline W95-25 & Wolf & 0.81 & 0.24 & 0.912 & 1.160 & 1.03 & 1.272 & $<0.2$ & 1.160 & & 1.272 & \\
\hline W95-54 & Wolf & 1.22 & 0.38 & 0.932 & 1.186 & 0.83 & 1.272 & & 1.186 & & 1.272 & \\
\hline W95-74 & Wolf & 0.74 & 0.24 & 1.001 & 1.186 & 0.77 & 1.185 & $<1$ & 1.188 & & 1.187 & \\
\hline W95-84 & Wolf & 1.05 & 0.33 & 0.940 & 1.164 & 0.69 & 1.238 & $<1.4$ & 1.167 & & 1.241 & \\
\hline SKV98-108 & Pinta & 1.25 & 0.28 & 0.677 & 1.014 & 0.77 & 1.499 & $<1.5$ & 1.019 & & 1.506 & \\
\hline SKV98-101 & Marchena & 0.73 & 0.20 & 0.834 & 1.092 & 0.65 & 1.309 & historical $\{1991\}$ & 1.092 & & 1.309 & \\
\hline
\end{tabular}




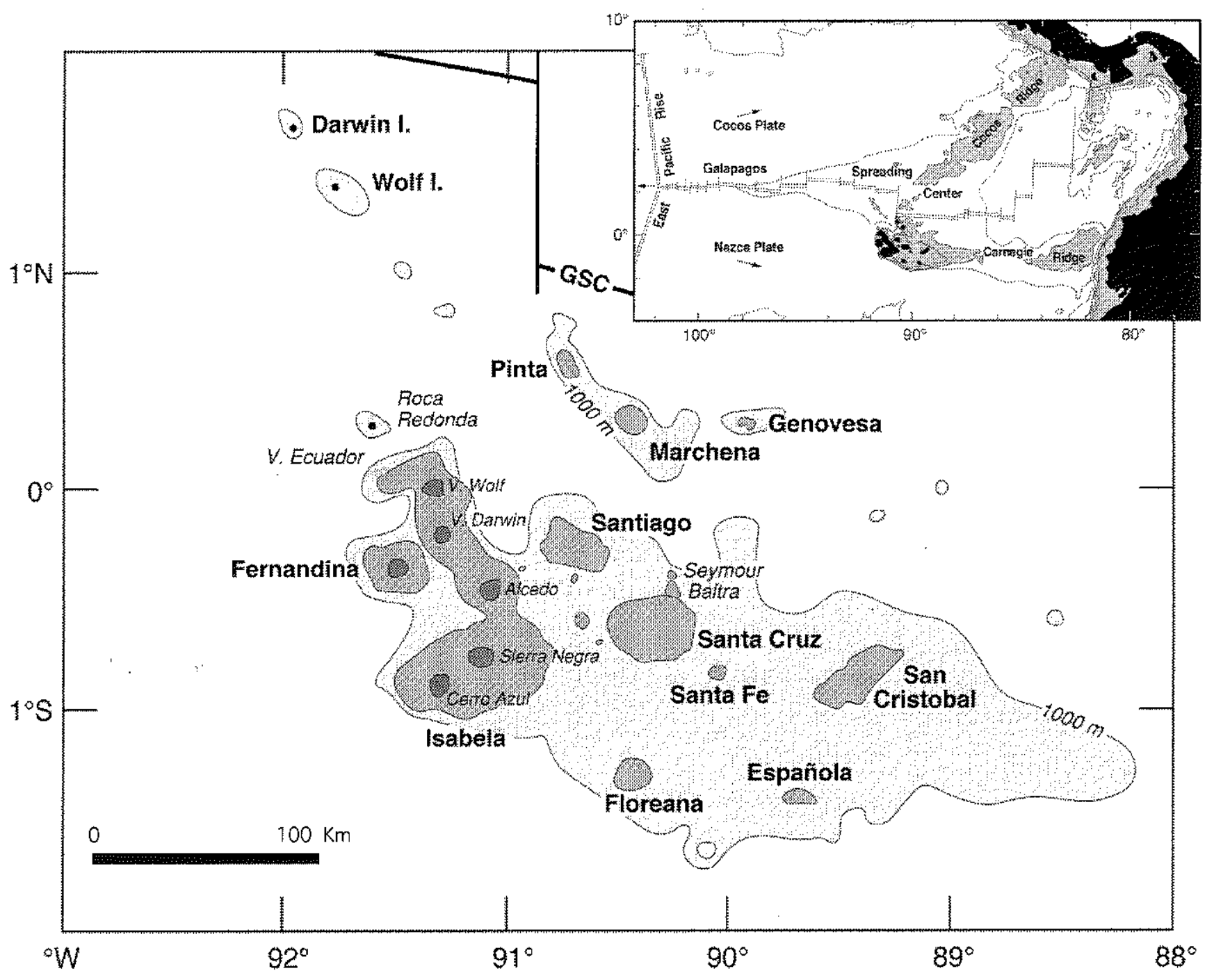

Figure 1 


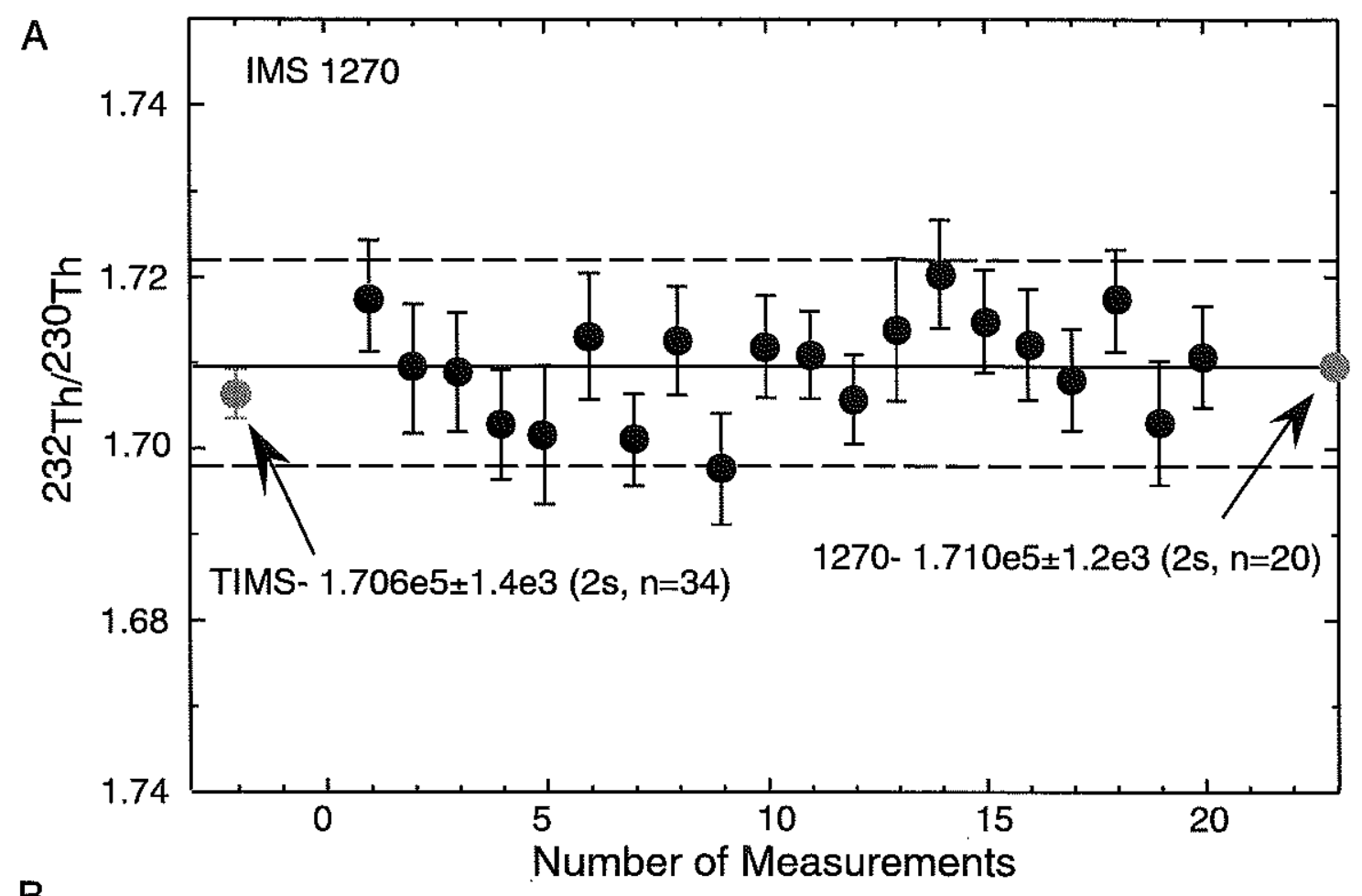

B

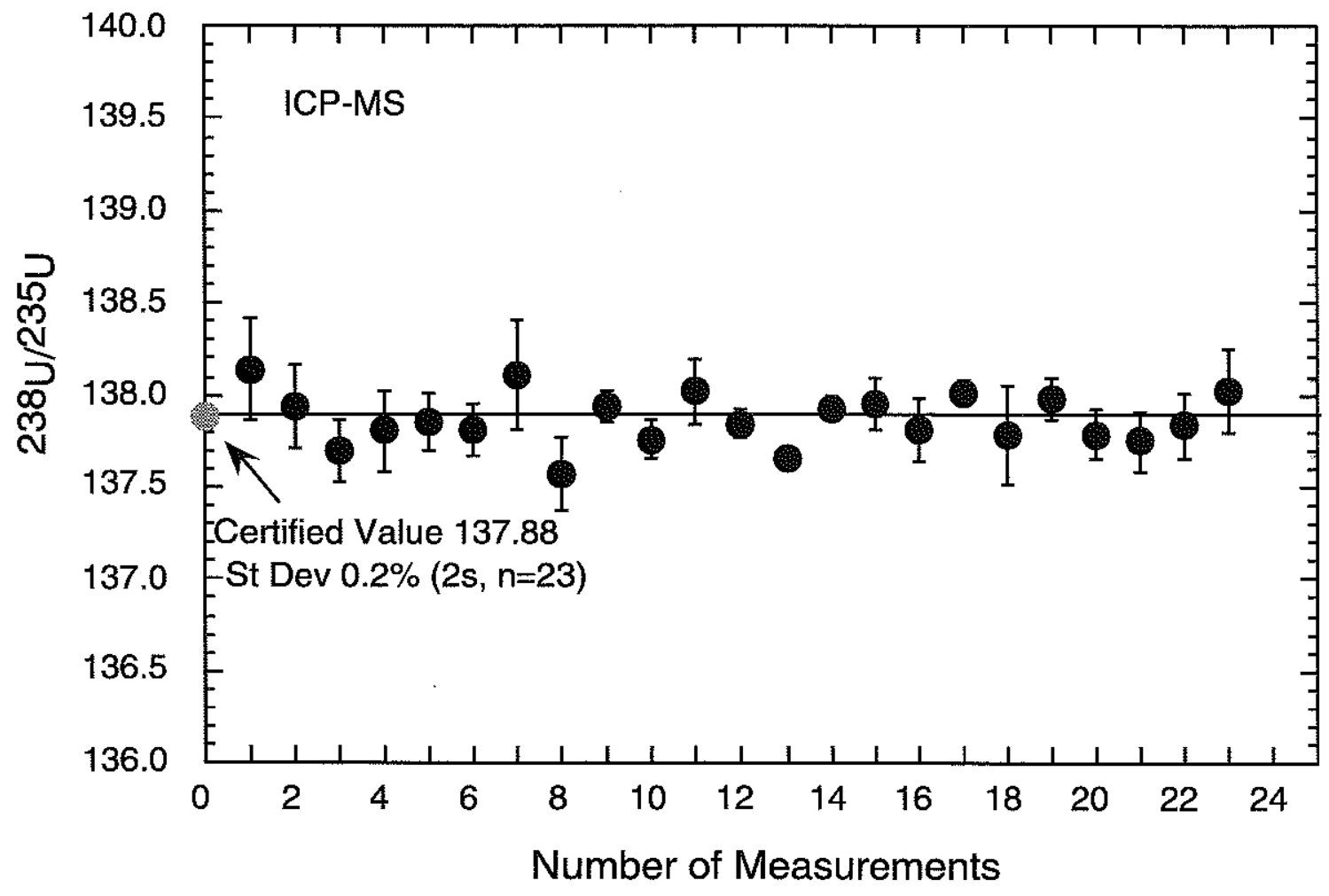

Figure 2 

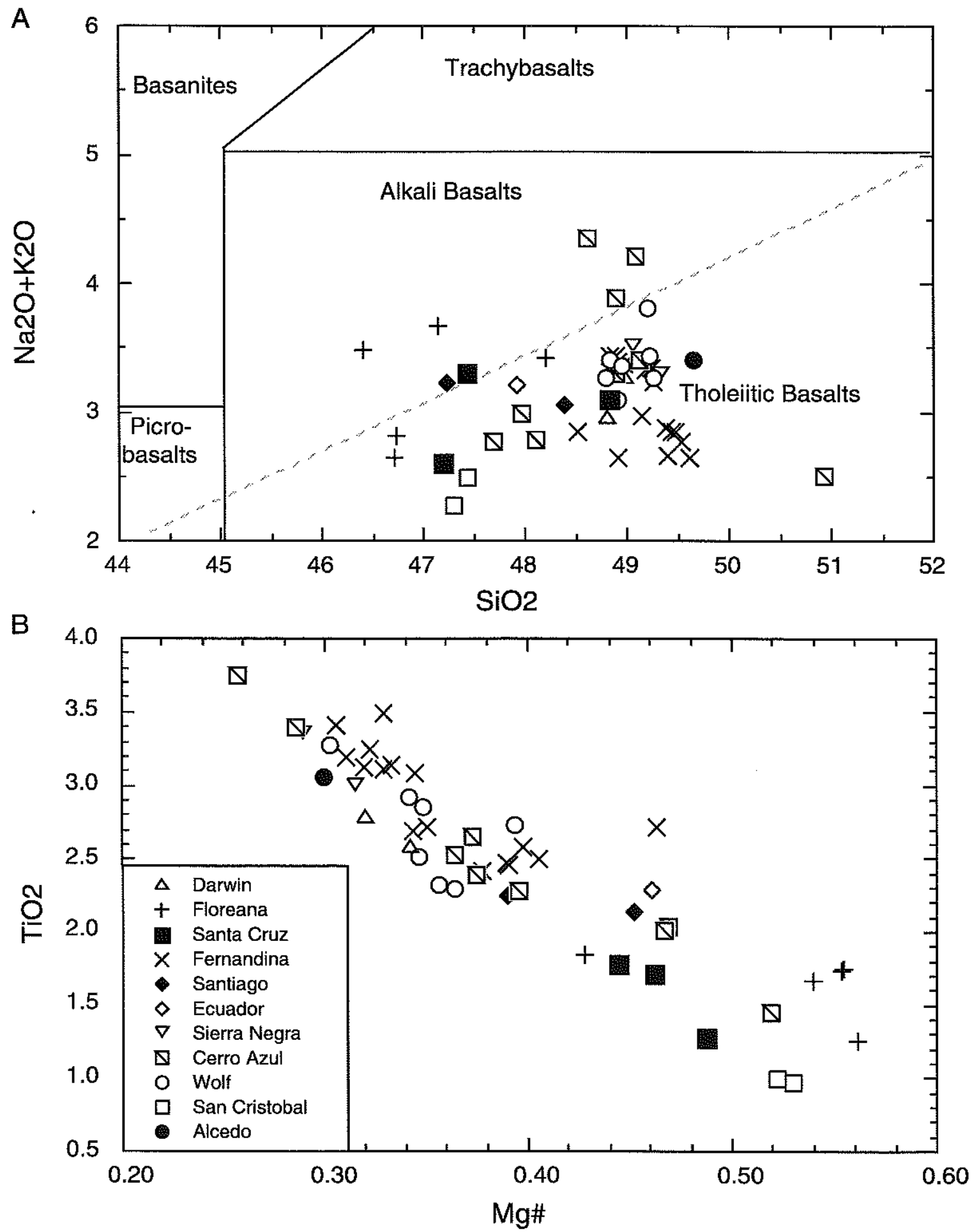

Figure 3 


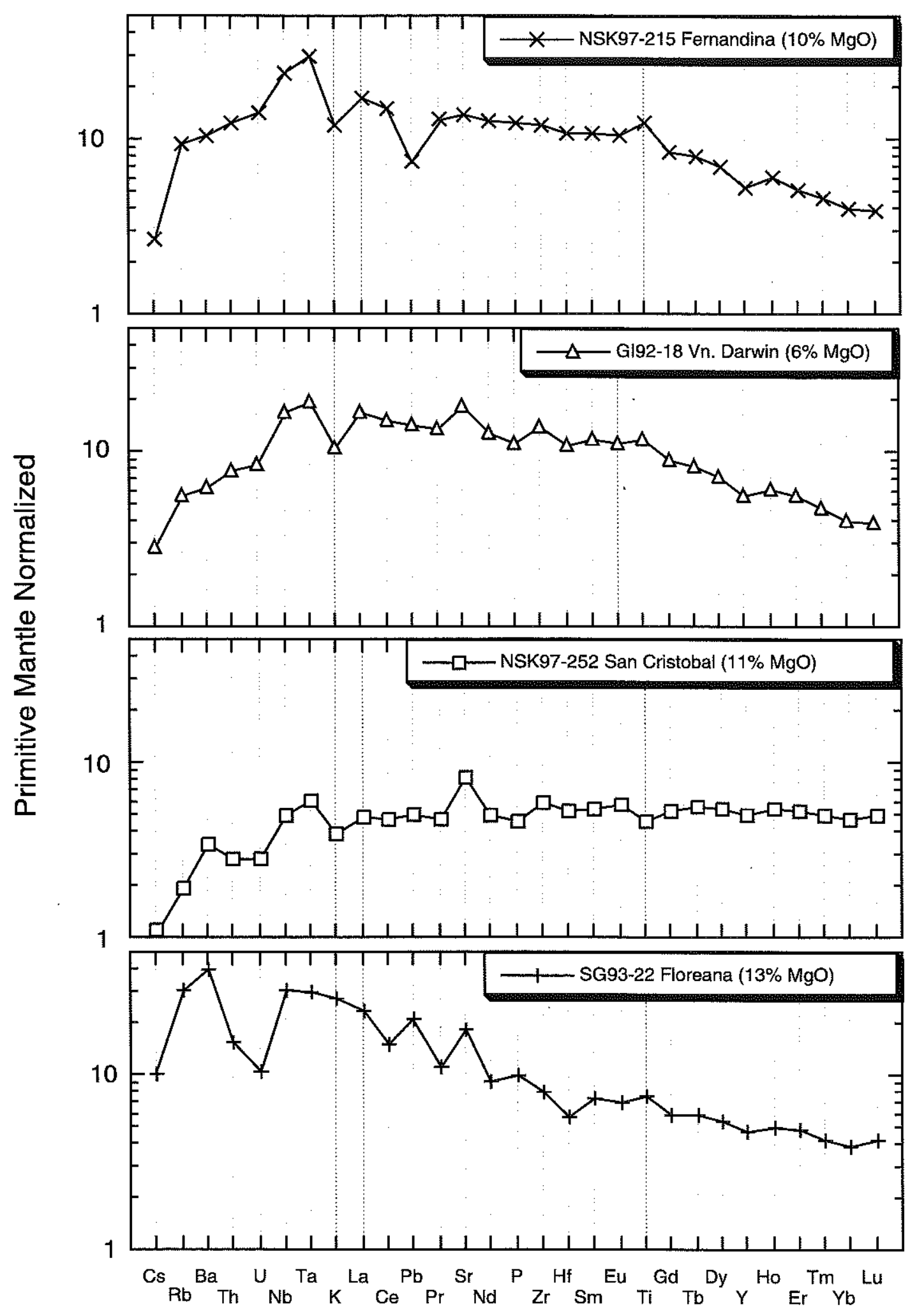

Figure 4 a 


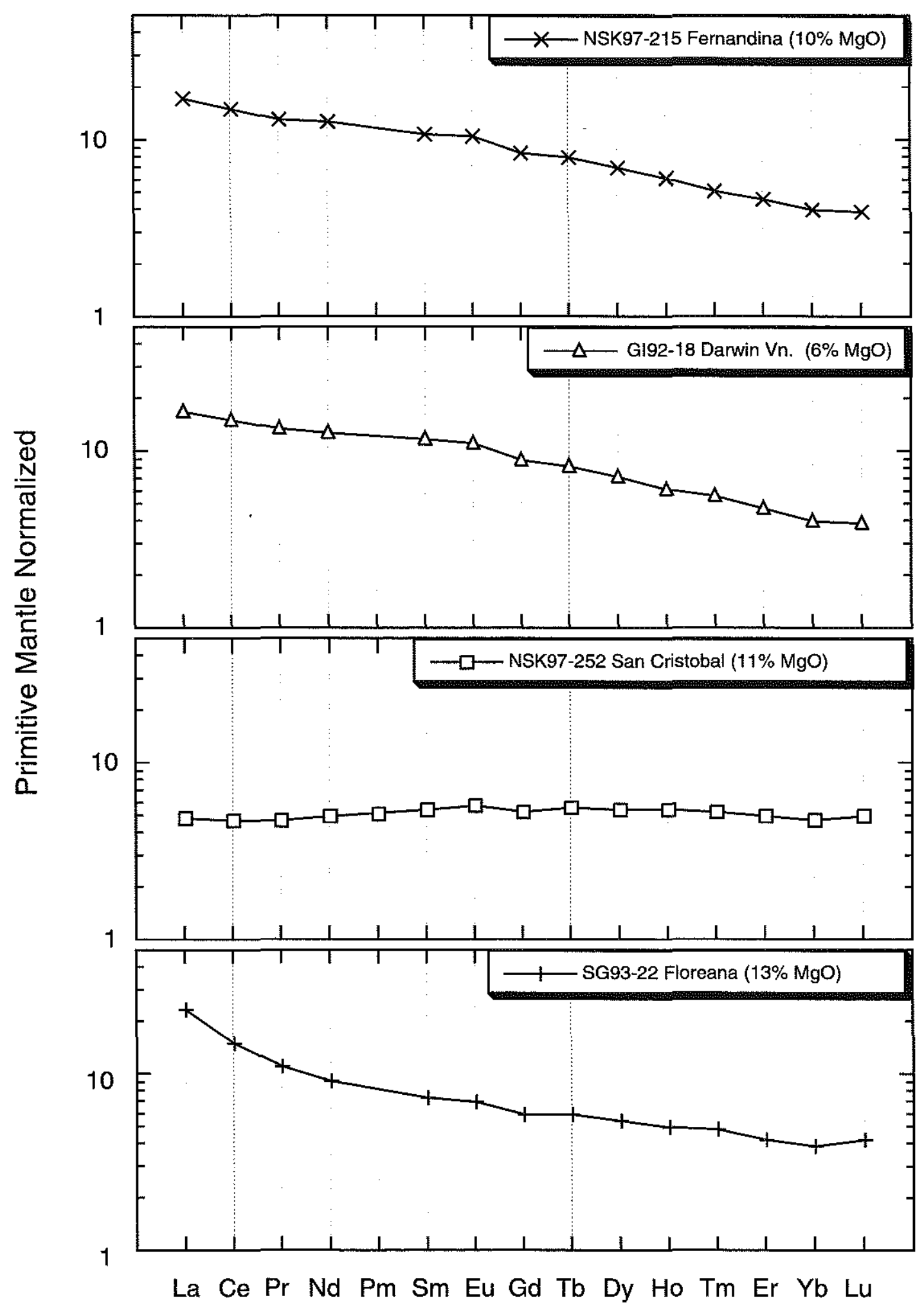

Figure $4 b$ 

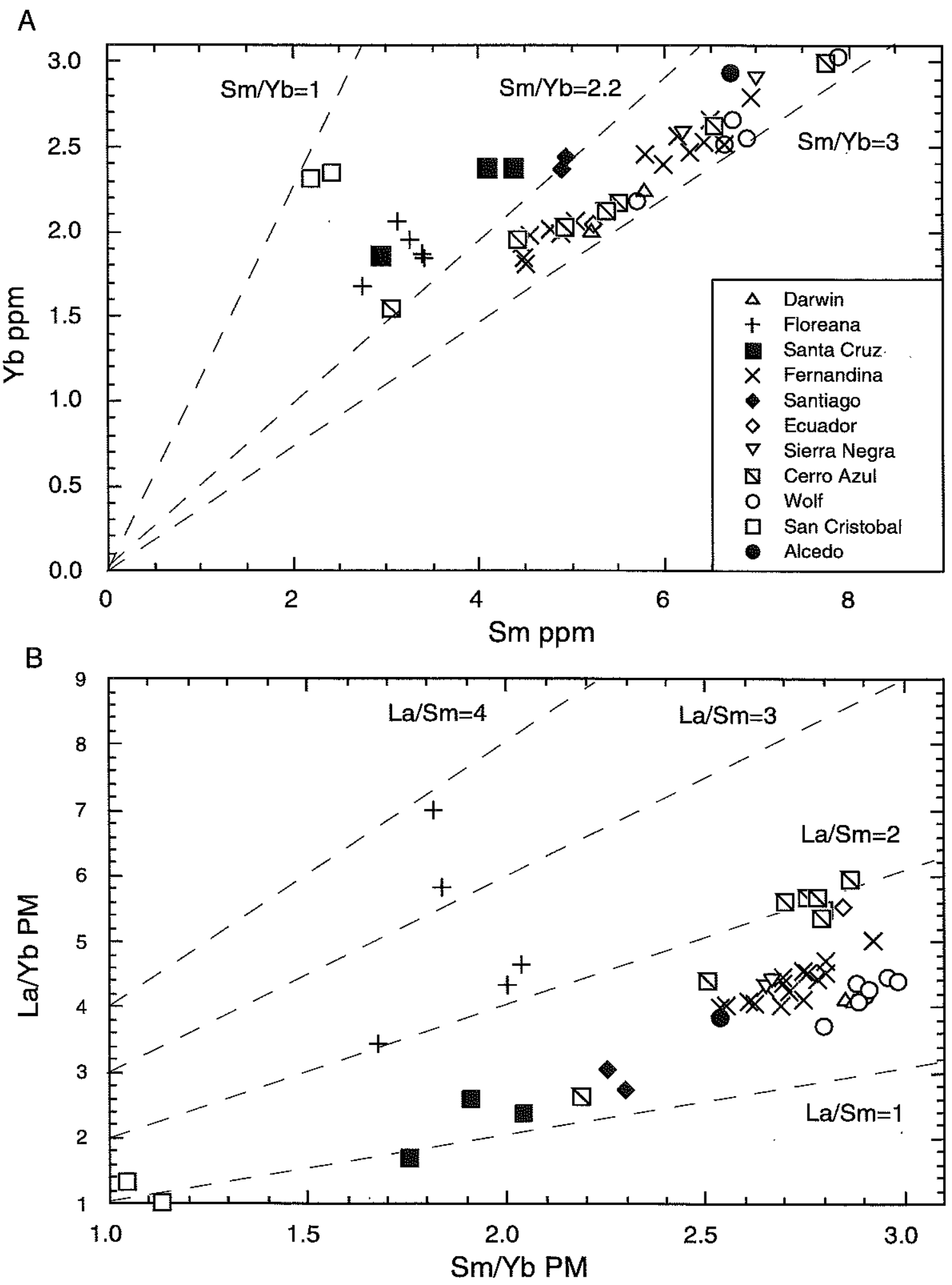

Figure 5 

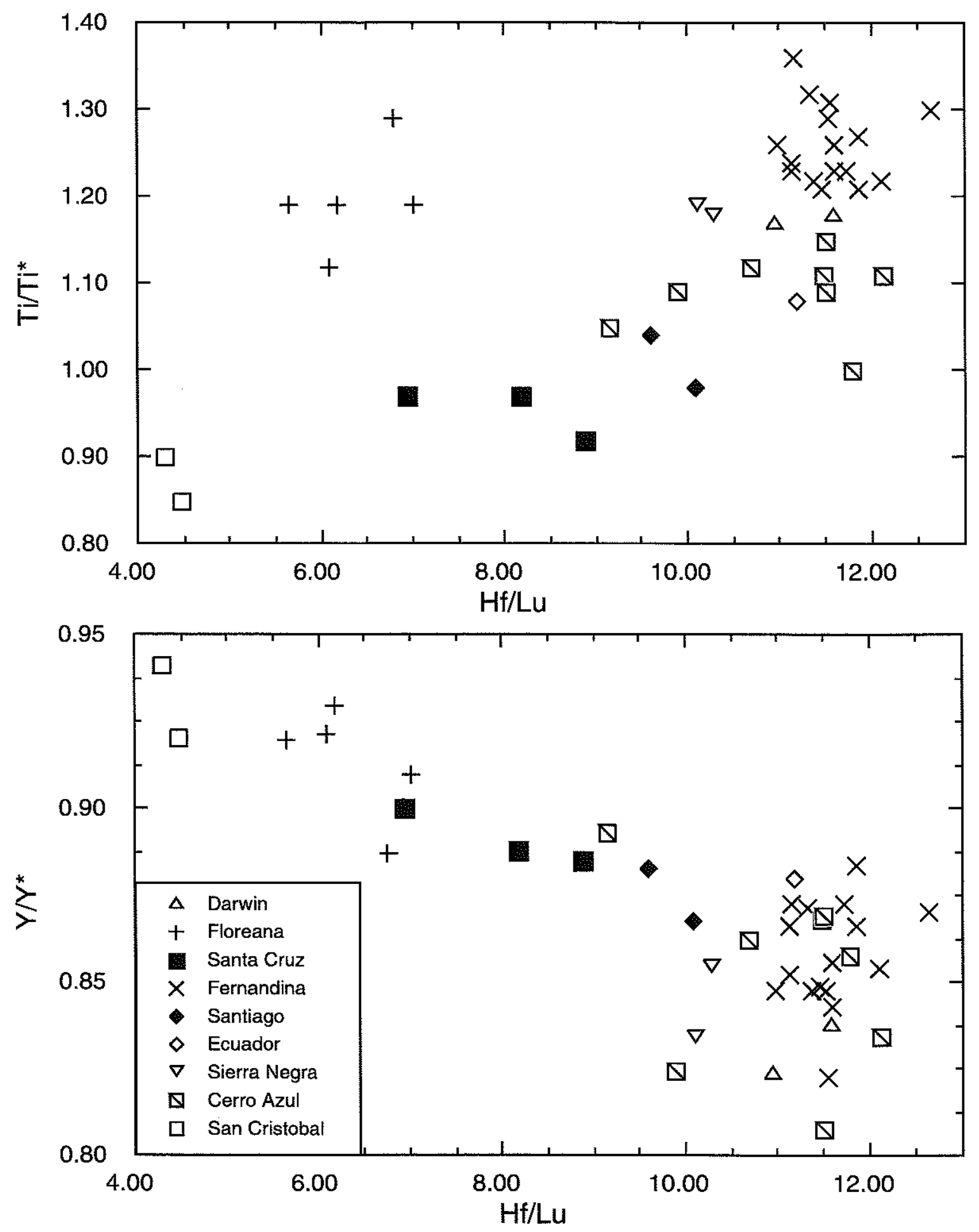

Figure 6 

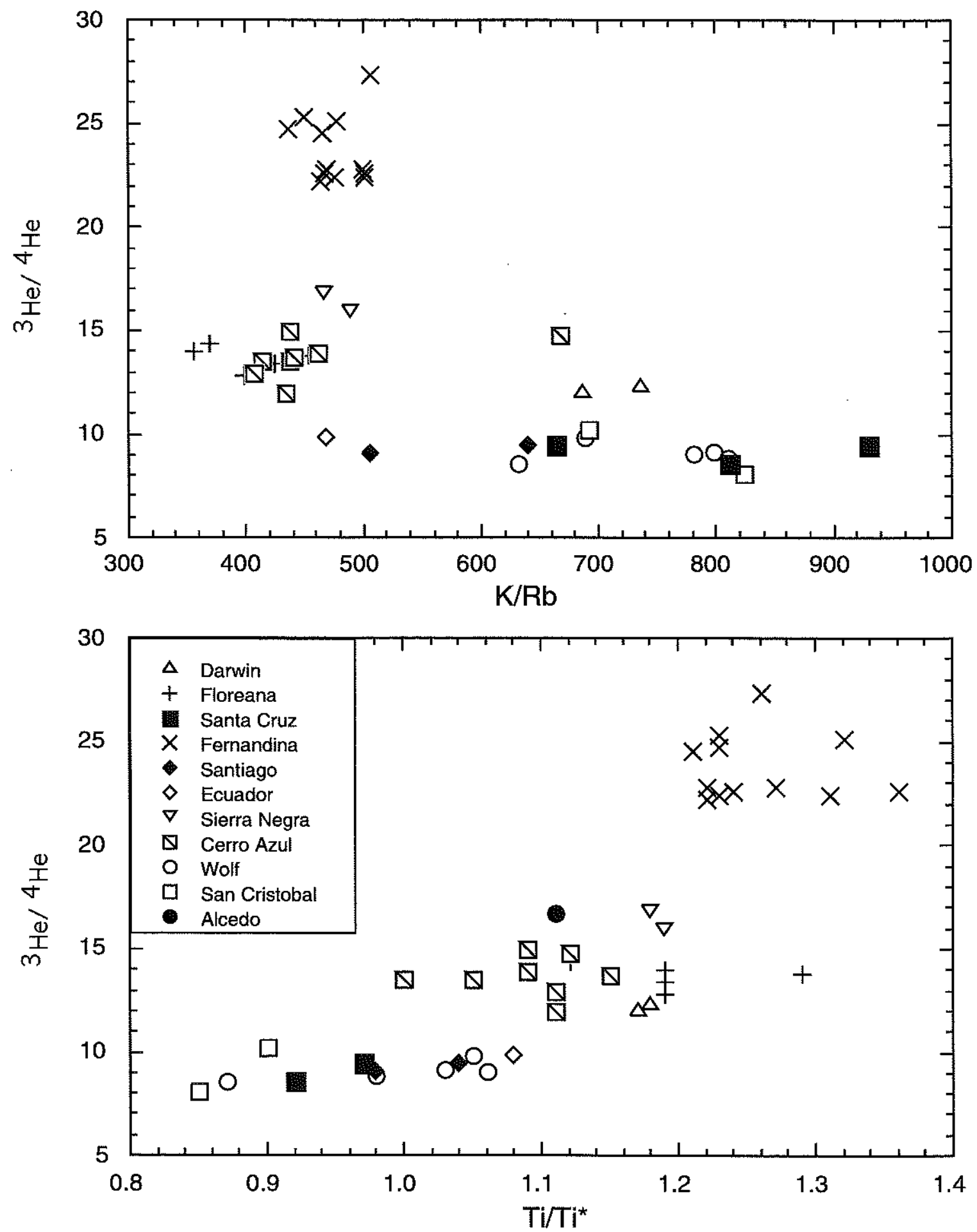

Figure 7 

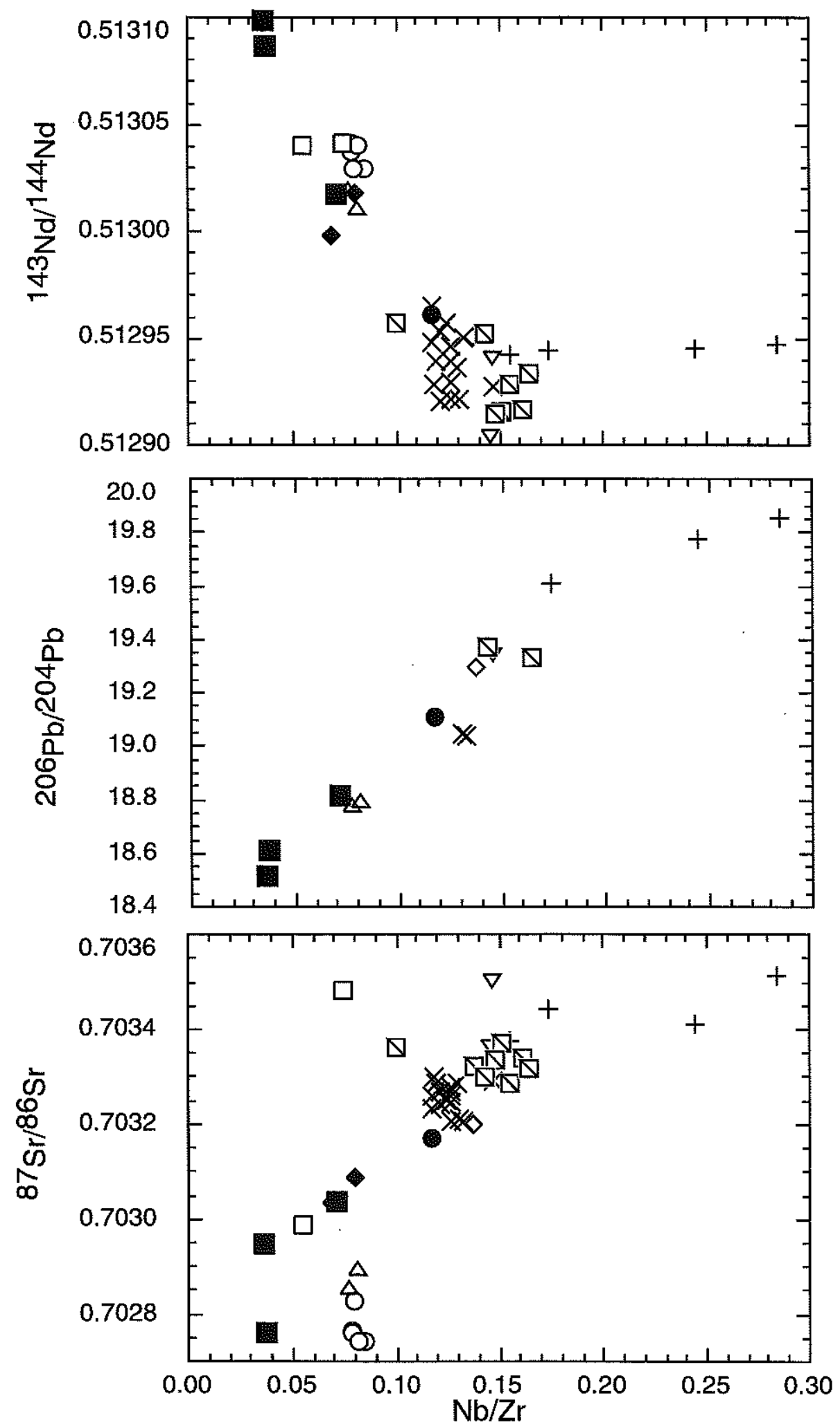

Figure 8 

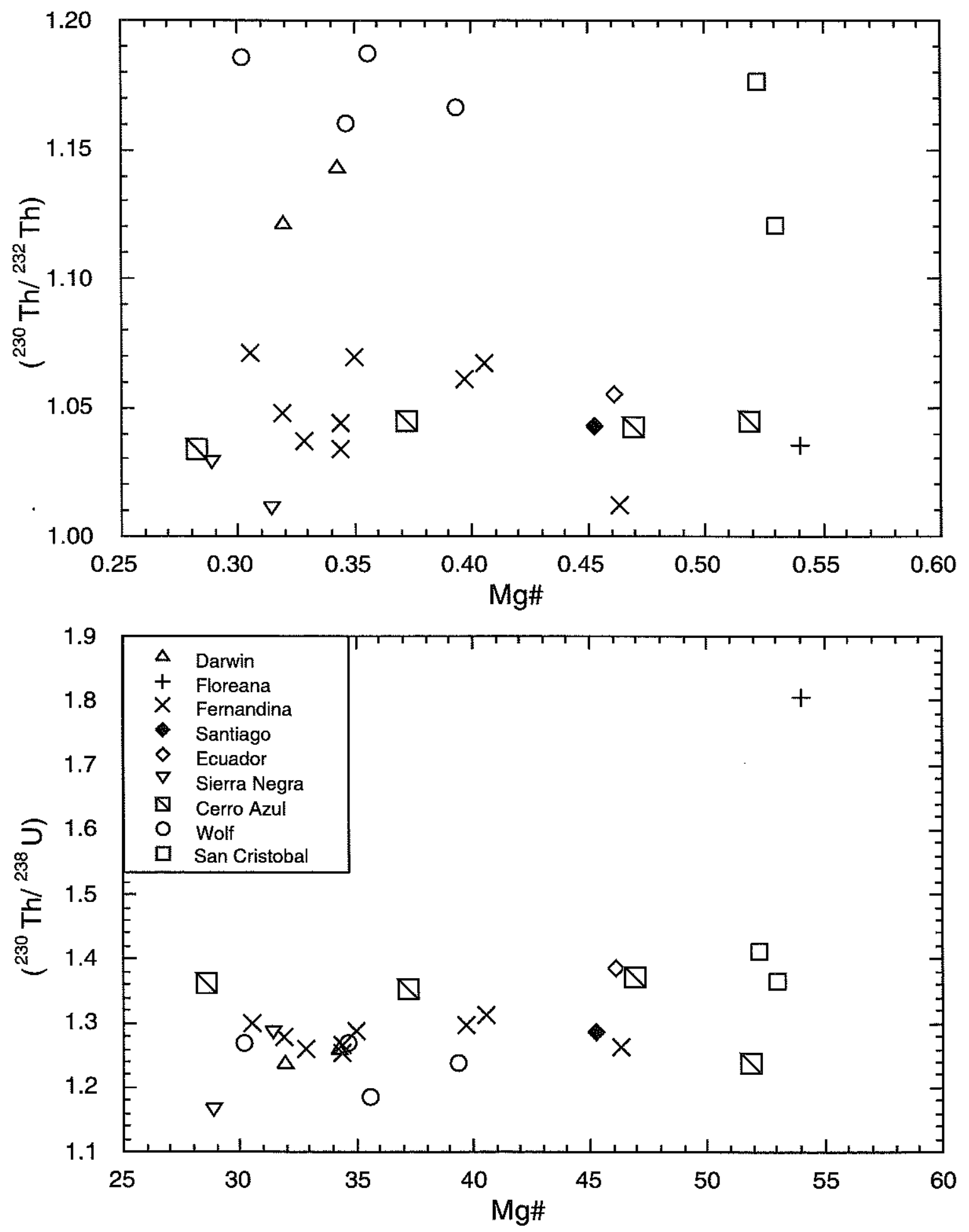

Figure 9 

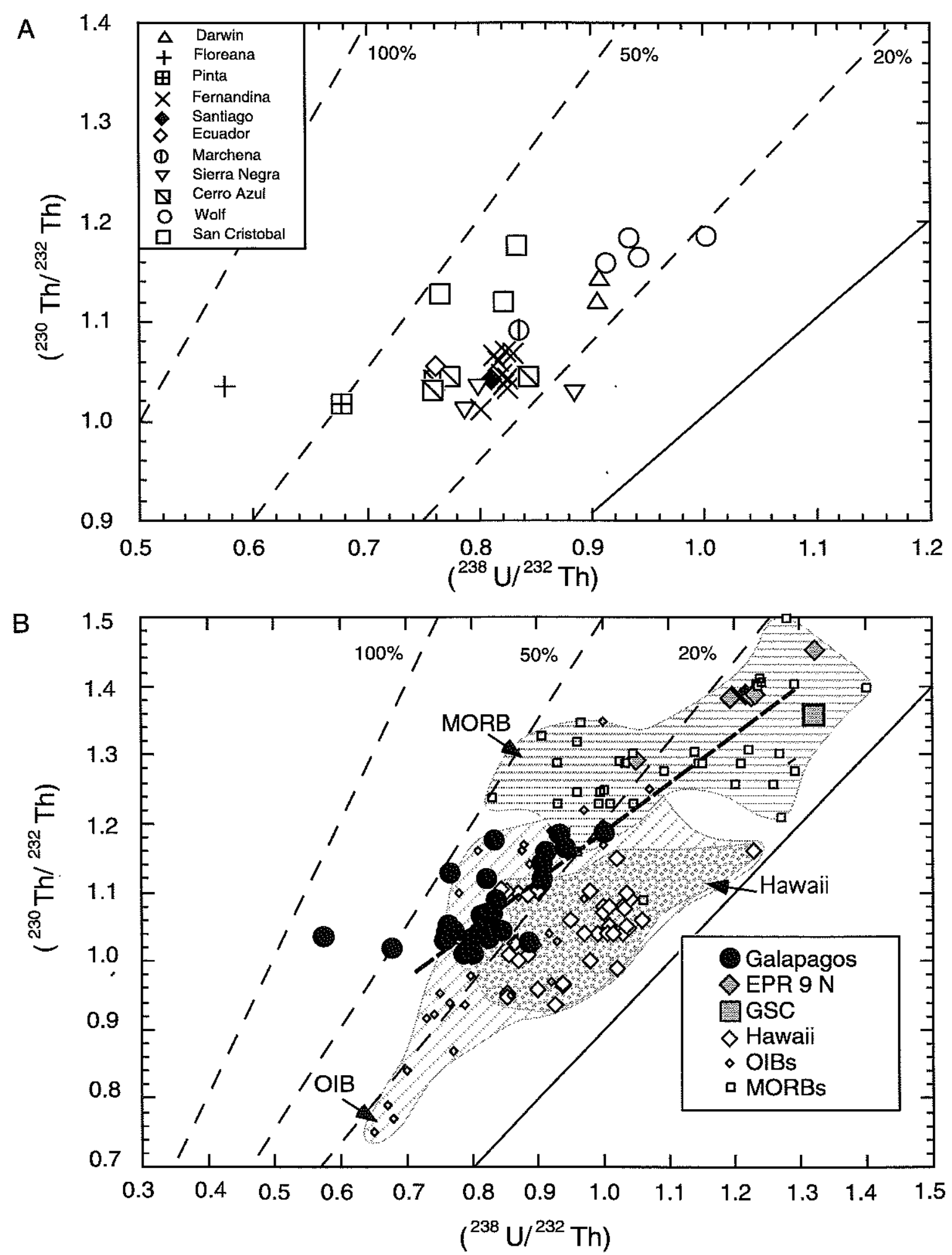

Figure 10 


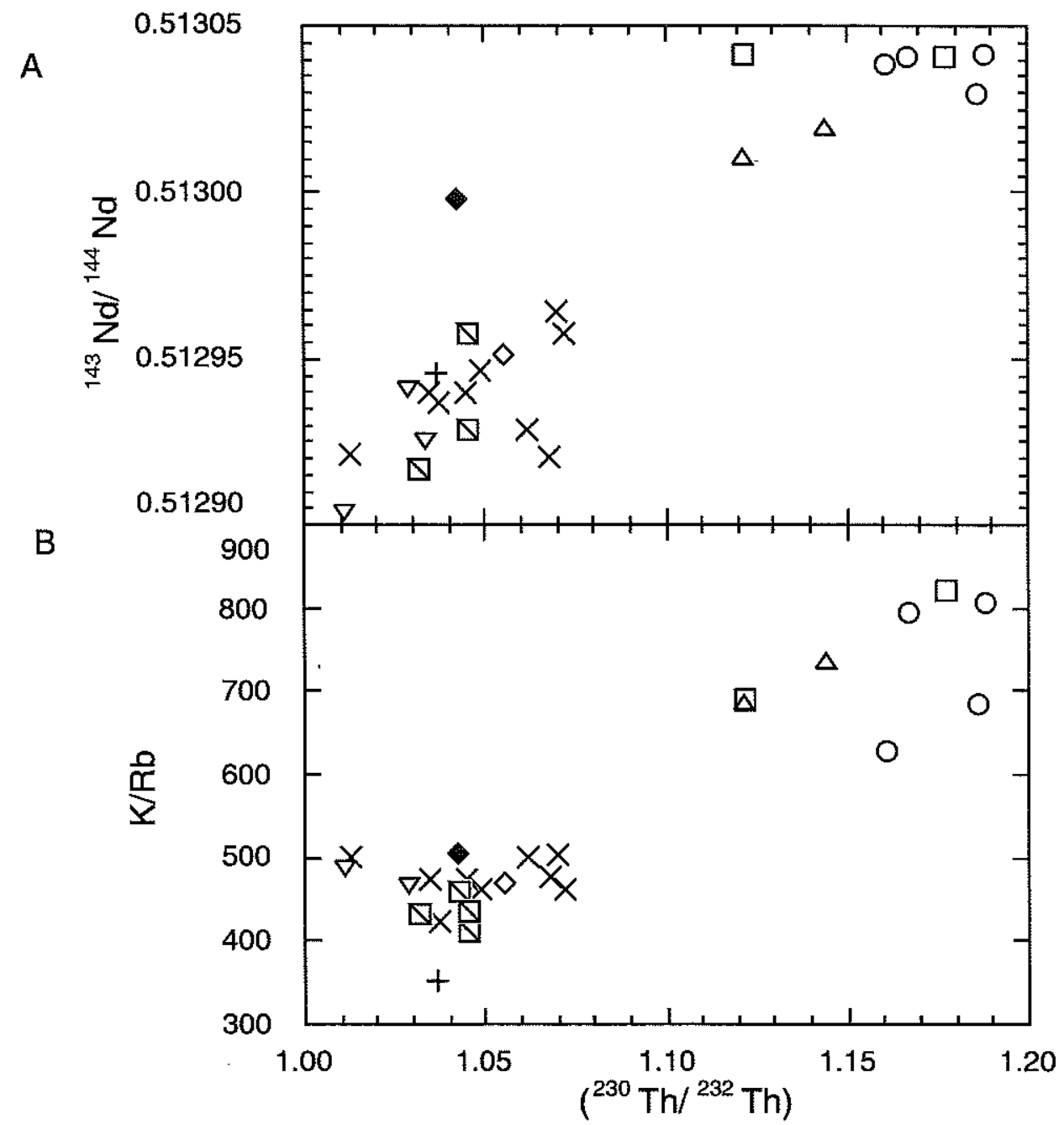

C

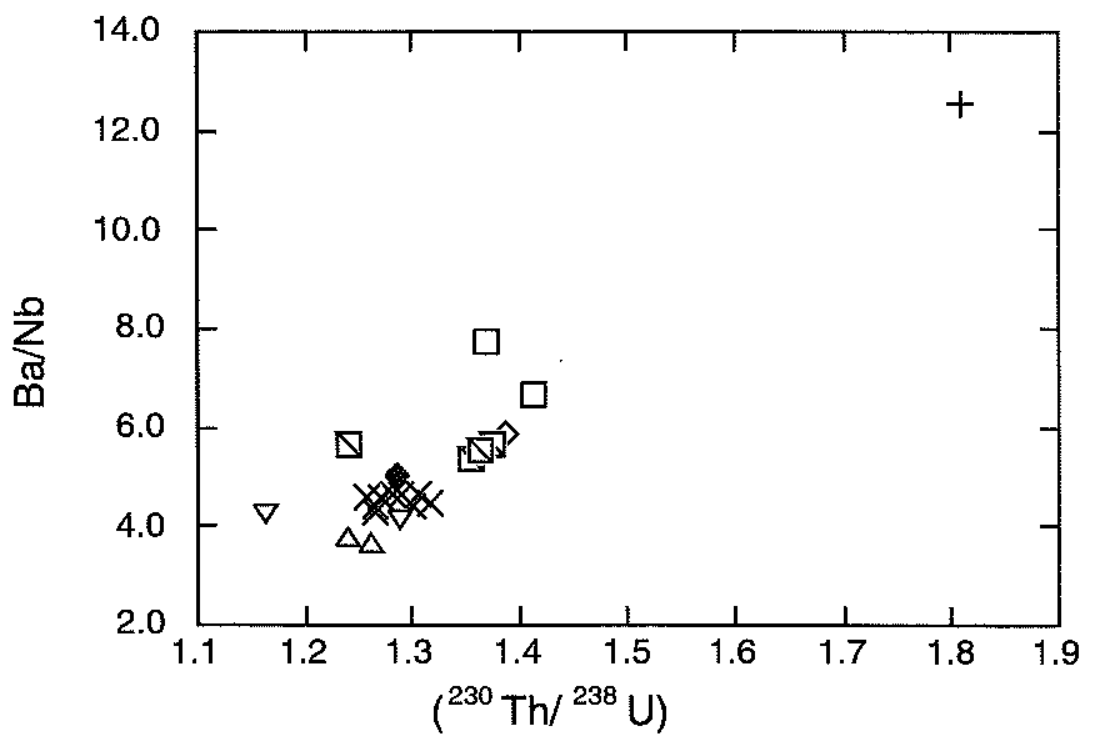

Figure 11 


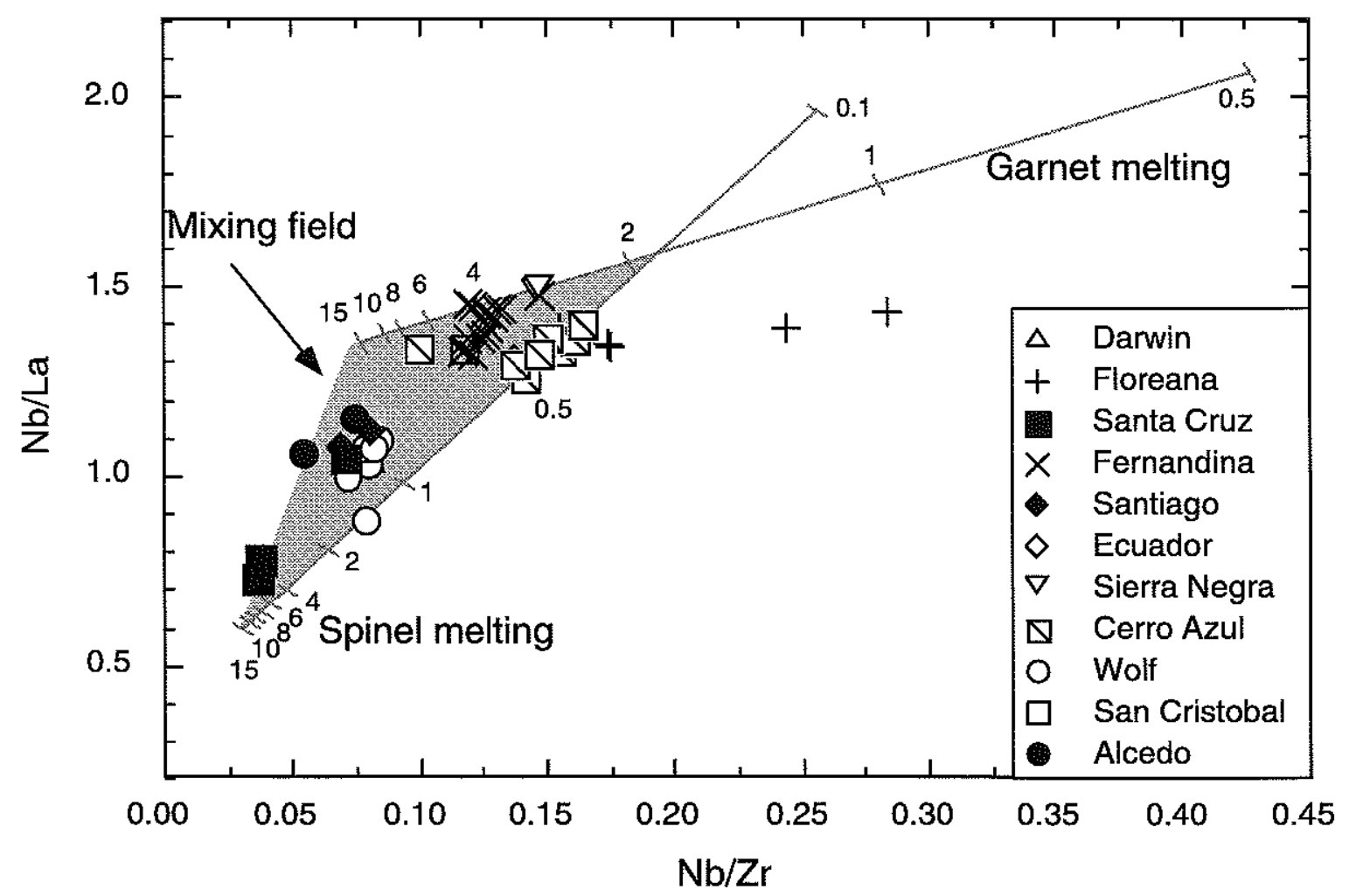

Figure 12 


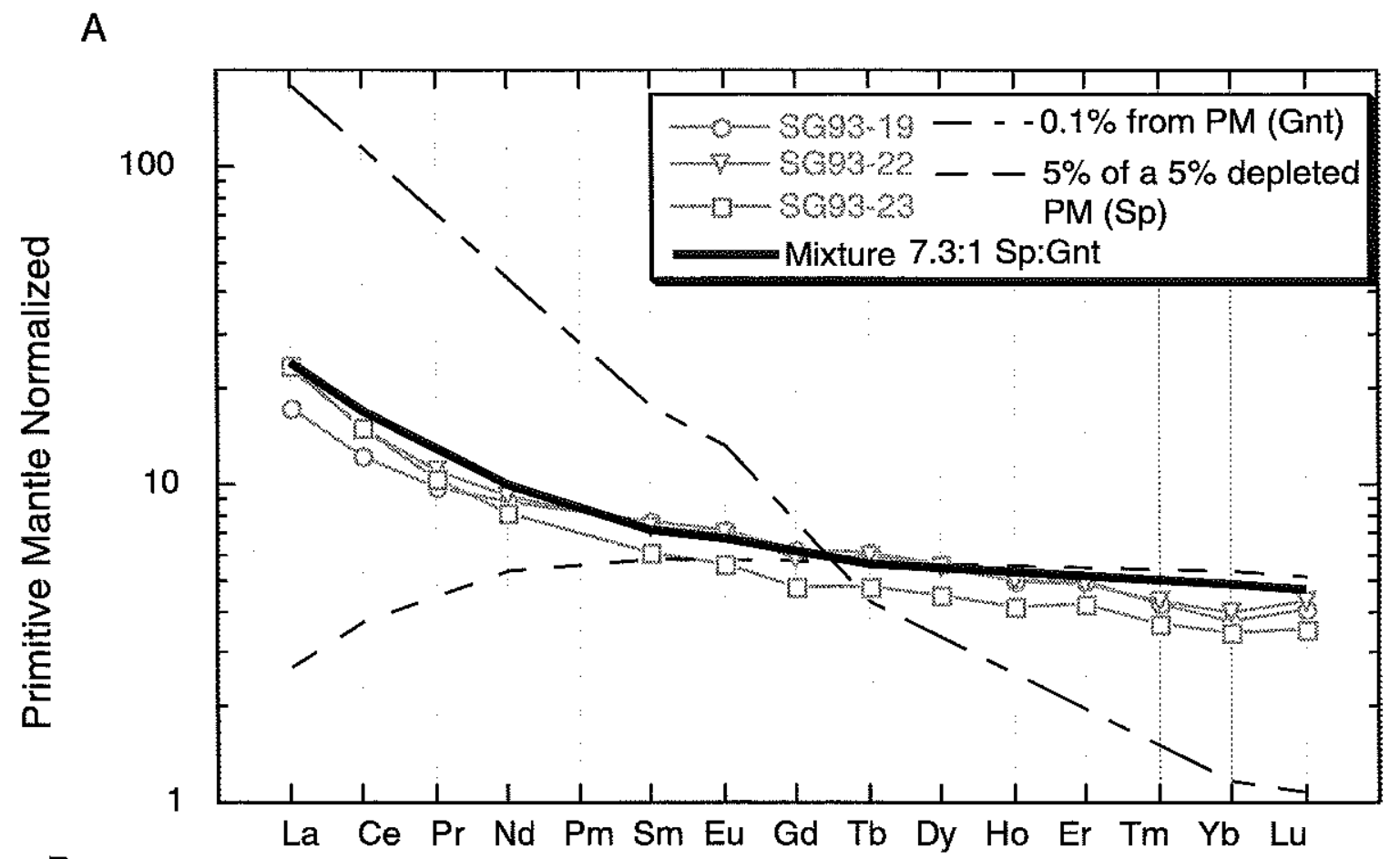

B

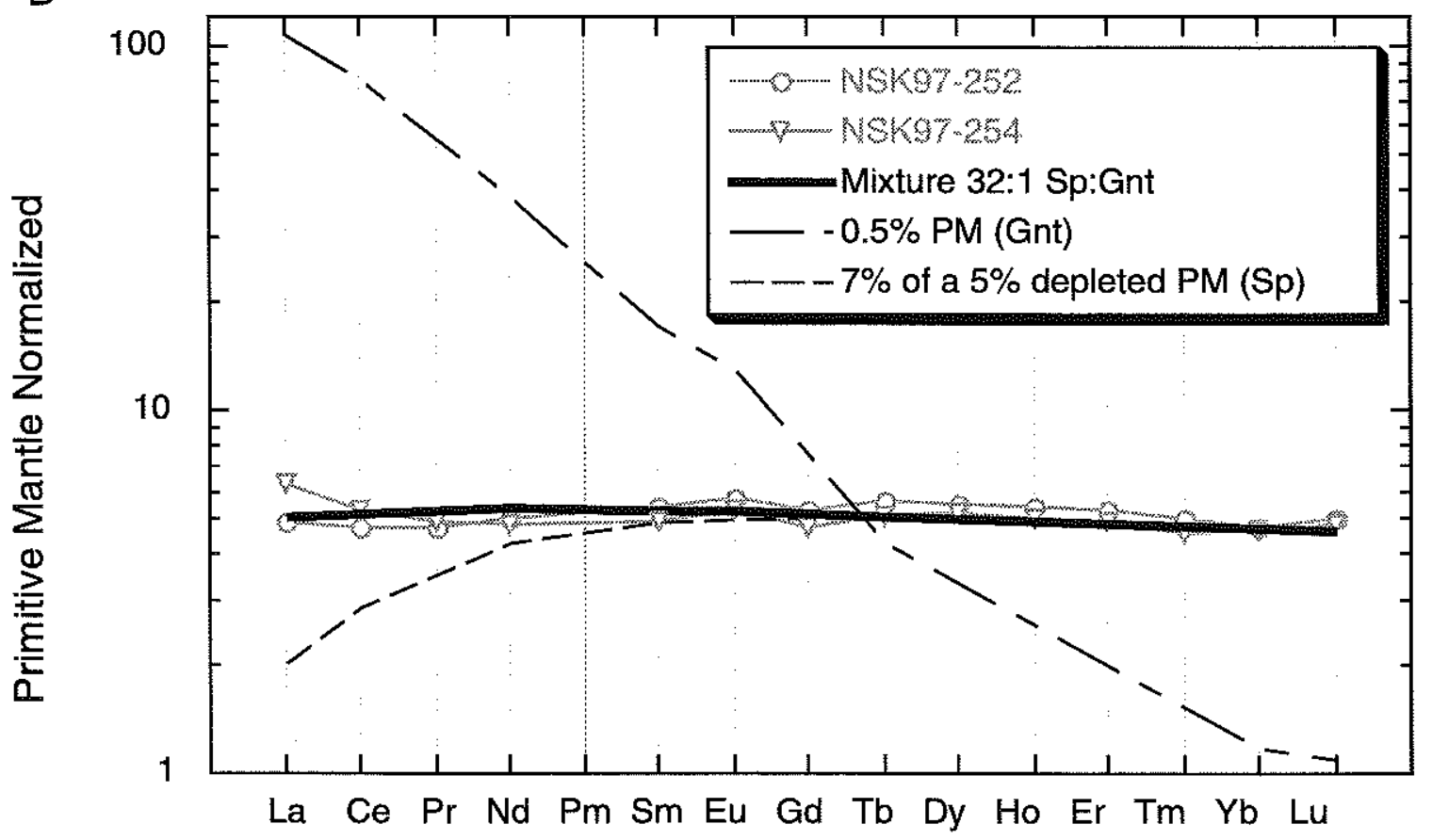

Figure 13 

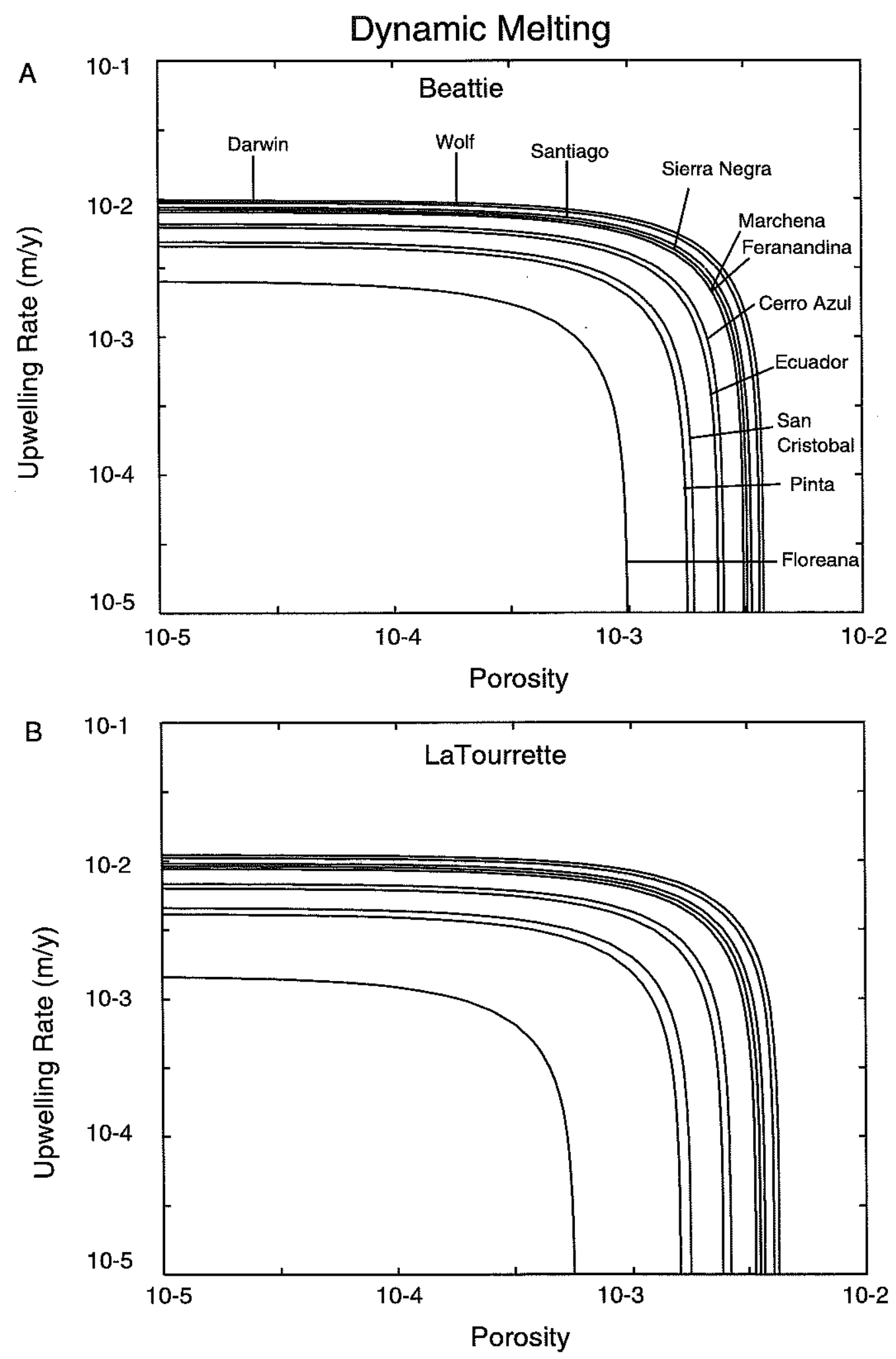

Figure 14 
Equilibrium Porous Flow

Extent of Melting

$0.5 \%$

$(1.7 \mathrm{~km})$

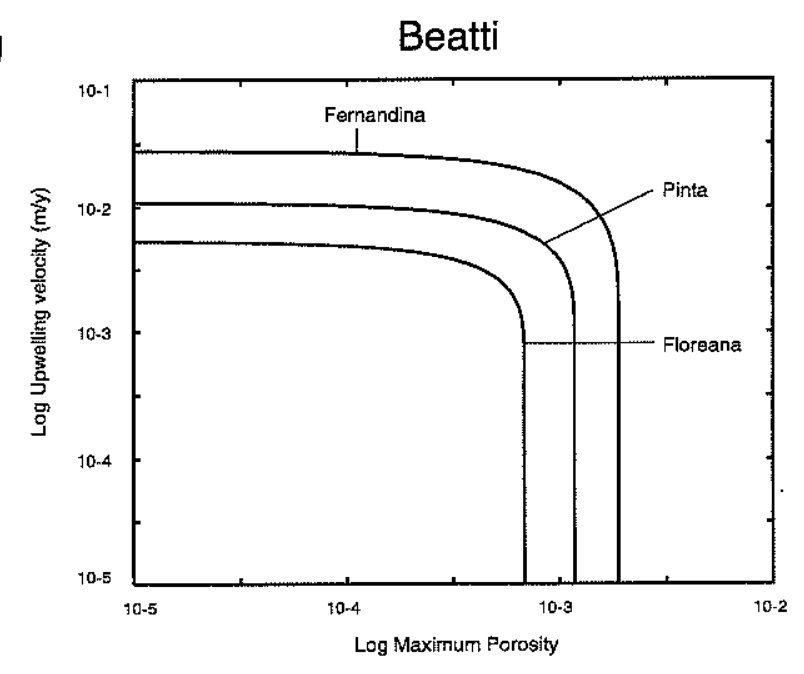

$\stackrel{N}{8}$

$1 \%$

(3 km)

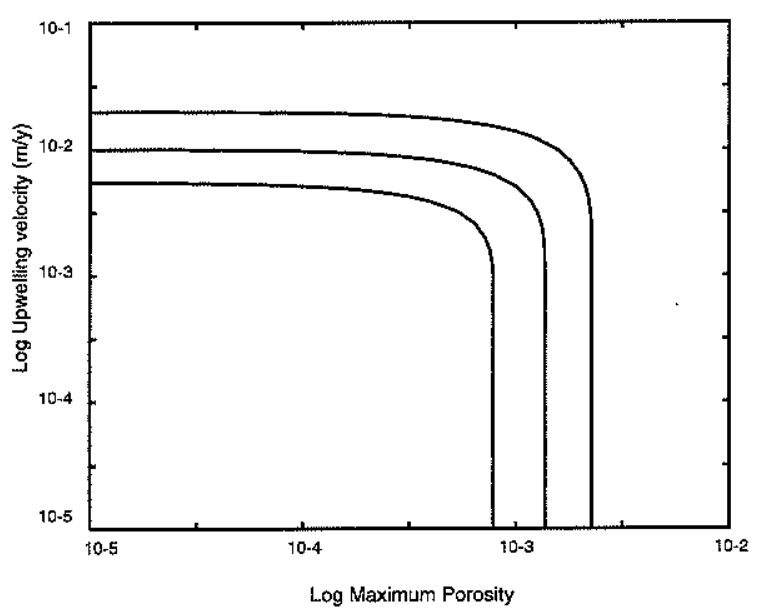

LaTourrette
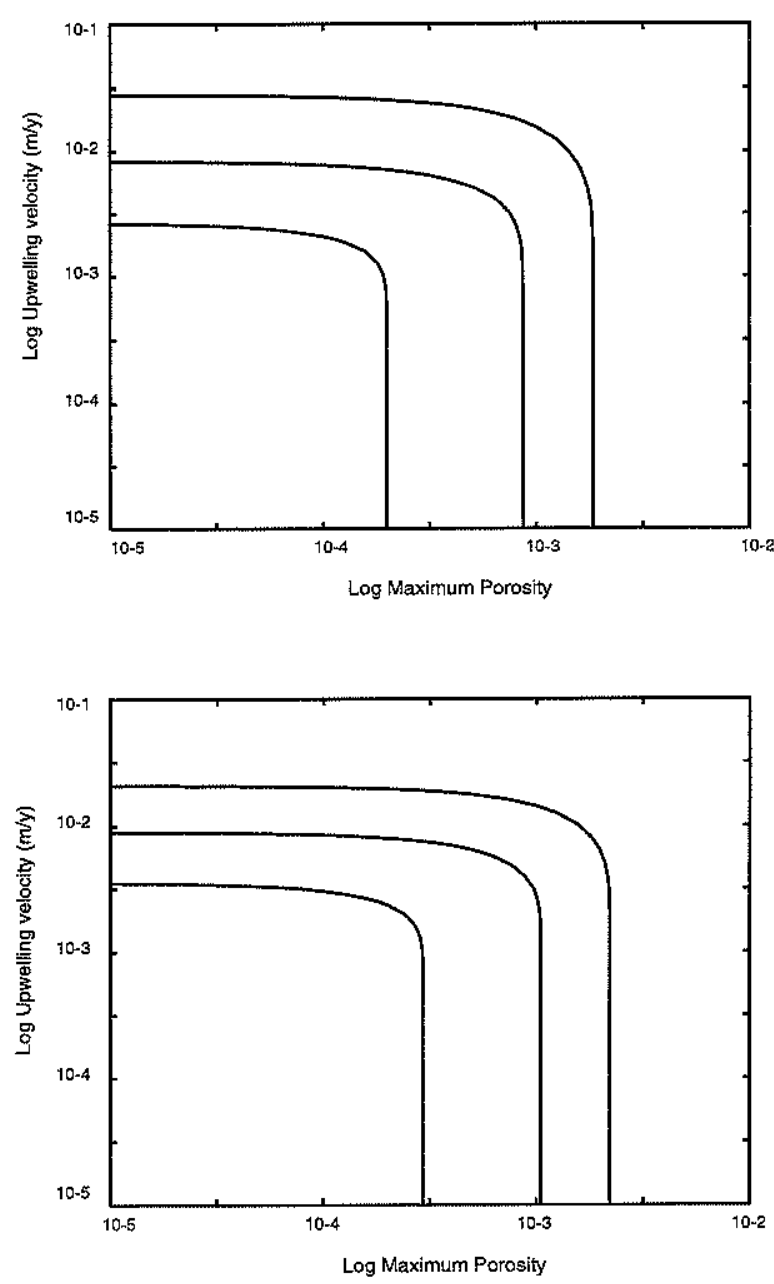

Figure 15 


\section{Equilibrium Porous Flow}
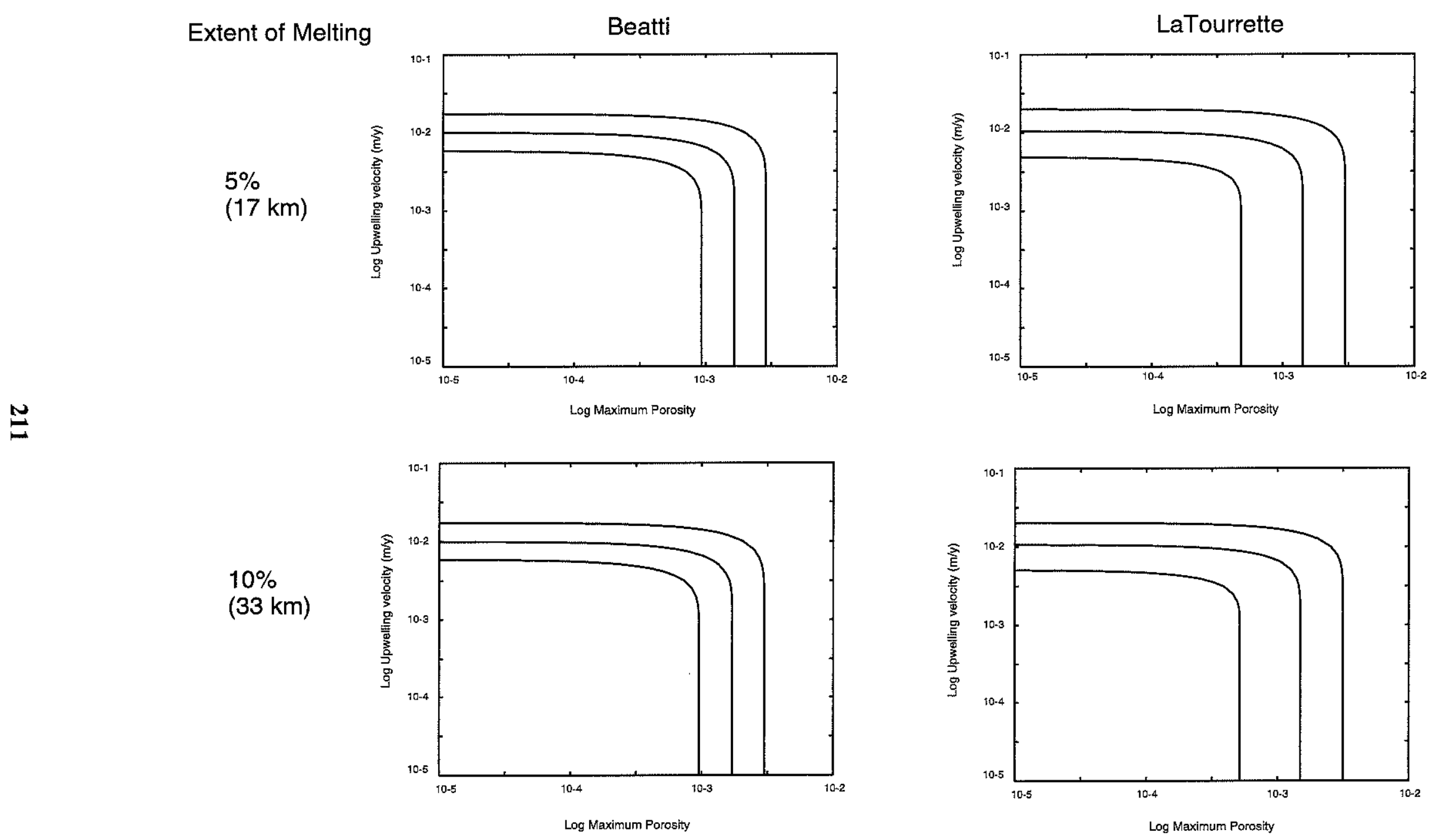

Figure 15 


\section{Conclusions}

The main goal of this study has been to use geochemical tracers to constrain the geologic processes responsible for the composition, formation and age of geochemically distinct Earth reservoirs. The strategy has been to work in a broad range of topics which are relevant to this end. This dissertation focus on four independent geochemical problems: defining the composition, formation and age of the lower continental crust and mantle lithosphere using Re-Os systematics, evaluating the scale of the mantle heterogeneities through a melt inclusion study from oceanic island basalts, and constraining the geodynamic parameters during upwelling and melting of mantle plume using U-series isotopes.

The Re-Os systematics in the deeper parts of the continental crust indicate that the lower crust has, on average, higher Os ( $\geq 2$ times) and lower Re concentrations than current estimates of the average upper crust, and may thus be comparatively less radiogenic. Materials with relatively high Os concentrations and radiogenic Os isotopic compositions exist in the lower crust, and may act as contaminants to basaltic magmas that differentiate there. The Re-Os system is extremely sensitive to AFC processes at relatively small degrees of differentiation (i.e., $<20 \%$ AFC), and AFC processes are more effective than bulk mixing in changing Os isotopic compositions of melts, due to Os depletion during fractional crystallization. Like other isotopic systems, the Re-Os system is not a good indicator of the crystallization age of rocks that formed through AFC processes.

Re-Os isotope systematics in Horoman peridotites indicate that ${ }^{187} \mathrm{Os} /{ }^{188} \mathrm{Os}$ ratios are mainly controlled by variations in Re content, while Re contents are controlled by the variation of a "basaltic component" in the ultramafic rocks. Geochemical, geological and petrographic information are consistent with the hypothesis that the N-Type plagioclase lherzolites and the layered structure of the Horoman massif are produced by refertilization processes. That is, the addition of a garnet-rich mafic cumulate to a depleted peridotite. $\mathrm{Re}-$ Os systematics suggest that depletion model ages of $\approx 1.8 \mathrm{Ga}$ represent the time of the melting event. The colinearity between mafic and ultramafic rocks in the Re-Os isochron diagram defines an apparent age of $\approx 1 \mathrm{Ga}$.. The similar "ages" determined by Re-Os and $\mathrm{Sm}-\mathrm{Nd}$ isotopes and the high $\mathrm{Re} / \mathrm{Os}$ ratios in the most fertile peridotites plotting to the right of the geochron, indicate that the mafic layers and the ultramafic rocks are genetically related by a refertilization process which took place $\approx 1 \mathrm{Ga}$ ago. 